VILNIAUS GEDIMINO TECHNIKOS UNIVERSITETAS

Audrius KRUKONIS

\title{
MIKROJUOSTELINIŲ LĖTINIMO SISTEMŲ TYRIMAS DAŽNINIAIS IR LAIKO SRITIES METODAIS
}

DAKTARO DISERTACIJA

TECHNOLOGIJOS MOKSLAI,

ELEKTROS IR ELEKTRONIKOS INŽINERIJA (01T)

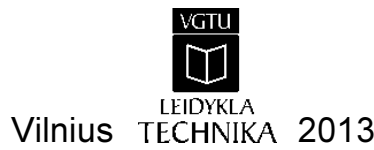


Disertacija rengta 2009-2013 metais Vilniaus Gedimino technikos universitete.

\section{Mokslinis vadovas}

prof. dr. Vytautas URBANAVIČIUS (Vilniaus Gedimino technikos universitetas, technologijos mokslai, elektros ir elektronikos inžinerija-01T).

VGTU leidyklos TECHNIKA 2169-M mokslo literatūros knyga http://leidykla.vgtu.lt

ISBN 978-609-457-562-4

(C) VGTU leidykla TECHNIKA, 2013

(C) Audrius Krukonis, 2013

audrius.krukonis@vgtu.lt 
VILNIUS GEDIMINAS TECHNICAL UNIVERSITY

Audrius KRUKONIS

\section{INVESTIGATION OF MICROSTRIP DELAY SYSTEMS IN FREQUENCY AND TIME DOMAIN}

DOCTORAL DISSERTATION

TECHNOLOGICAL SCIENCES,

ELECTRICAL AND ELECTRONIC ENGINEERING (01T)

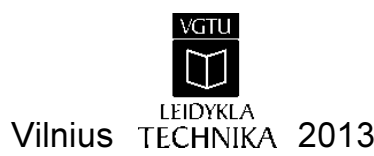


Doctoral dissertation was prepared at Vilnius Gediminas Technical University in 2009-2013.

\section{Scientific Supervisor}

Prof Dr Vytautas URBANAVIČIUS (Vilnius Gediminas Technical University, Technological Sciences, Electrical and Electronic Engineering - 01T). 


\section{Reziumè}

Disertacijoje sprendžiama lètinimo sistemų kraštinių ir galinių laidininkų itakos modeliu tikslumui ivvertinimo problema. Pagrindiniai tyrimo objektai daugialaidžių ir meandrinių mikrojuostelinių linijų matematiniai modeliai, skaitiniai analizès metodai. Darbo tikslas - sukūrus modelius, grịstus baigtinių skirtumų laiko srities metodu, ištirti galinių ir kraštinių laidininkų netolygumų įtaką meandrinių mikrojuostelinių vèlinimo linijų laiko ir dažninèms charakteristikoms, pasiūlyti meandrinių vèlinimo linijų konstrukcijų tobulinimo priemones.

Darbe sprendžiami uždaviniai: matematinių pavienès, susietujjų ir daugialaidžių mikrojuostelinių linijų modelių sudarymas ir savybių tyrimas, taikant baigtinių skirtumų bei baigtinių skirtumų laiko srities analizės metodus; daugialaidžių mikrojuostelinių linijų sintezès ir meandrinių mikrojuostelinių vèlinimo linijų analizès algoritmų bei jų elektrinių charakteristikų skaičiavimo metodikų sudarymas.

Disertaciją sudaro įvadas, keturi skyriai, bendrosios išvados, naudotos literatūros ir autoriaus publikacijų disertacijos tema sąrašai.

Ivadiniame skyriuje formuluojama tiriamoji problema, aptariamas darbo aktualumas, aprašomas tyrimų objektas, formuluojamas darbo tikslas bei uždaviniai, aprašoma tyrimu metodika, darbo mokslinis naujumas, rezultatų praktiné reikšmè, ginamieji teiginiai. İvado pabaigoje pristatomi pranešimai konferencijose disertacijos tema bei pateikiama disertacijos struktūra.

Pirmajame skyriuje pateikiama literatūros analizè, aptariamos lètinimo sistemų taikymo sritys. Analizuojama létinimo įtaisų projektavimo ir sintezès analitiniais, skaitiniais metodais problema. Aptariamas autoriaus indèlis i nagrinèjamos problemos sprendimą. Skyriaus pabaigoje formuluojamos išvados ir tikslinami disertacijos uždaviniai.

Antrajame skyriuje parenkami mikrojuostelinių linijų konstrukcinių parametrų sintezei naudojami metodai. Sudaromos elektrinių parametrų skaičiavimo metodikos ir pateikti tyrimo rezultatai.

Trečiajame skyriuje tiriamos susietujų ir daugialaidžių mikrojuostelinių linijų matematiniai modeliai, pateikiami tyrimo rezultatai. Sudaromos tolygios ir netolygios būdingosios varžos skaičiavimo ir sintezès metodikos.

Ketvirtajame skyriuje parodoma daugialaidès mikrojuostelinès linijos laidininkų parametrų netolygumo ịtaka meandrinès mikrojuostelinès vèlinimo linijos charakteristikoms.

Disertacijos tema paskelbti 7 moksliniai straipsniai, iš kurių šeši - recenzuojamuose mokslo žurnaluose, o iš šių - trys mokslo žurnaluose, įtrauktuose i Thomson Reuters Web of Science duomenų bazę. Disertacijos tema perskaityti aštuoni pranešimai mokslinèse konferencijose. 


\section{Abstract}

There are investigated accuracy issues of edges and ends evaluation problems of meander slow-wave systems in the dissertation. Objects of research mathematical models of multiconductor and meander microstrip delay lines, numerical analysis methods. Aim of the work - after creating mathematical models, based on finite difference time domain method, explore ends and edges discontinuity effects on meander microstrip delay lines time and frequency characteristics, propose structural improvement measures of meander delay line.

The dissertation approaches major tasks such as: mathematical individual, coupled, multiconductor microstrip lines models composition for performance and their properties investigation using finite difference and finite difference time domain methods of analysis; synthesis algorithm of multiconductor microstrip lines and analysis algorithm of meander microstrip delay line and methodology of their electrical characteristics calculation creation.

The thesis consists of four parts including introduction, 4 chapters, conclusions, references.

The introduction reveals investigated problem, importance of the thesis and object of research. It also describes the purpose and tasks of the dissertation, research methodology, scientific novelty and the practical significance of results examined in the thesis and defended statements. The introduction ends in presenting the author's publications on the subject of the defended dissertation, offering the material of made presentations in conferences and defining the structure of the dissertation.

In the first chapter used literature are revised. At the end of the chapter conclusions are drawn and the tasks for the dissertation are reconsidered.

In the second chapter methods used for synthesis of microstrip line structure parameters is described. Electrical parameters calculation methodology is created and calculation results are presented.

In the third chapter mathematical models of coupled and multiconductor microstrip lines are investigated, presented the results of the investigations. Uniform and non-uniform characteristic impedance calculation and synthesis methodologies are created.

In the fourth chapter multiconductor microstrip line inhomogenity of conductors' parameters on meander microstrip delay line characteristics is proven.

7 articles focusing on the subject of the discussed dissertation are published: six articles in reviewed scientific journals, three of them in Thomson Reuters Web of Science data base and one article - in conference proceedings. 8 presentations on the subject have been given in conferences on national and international level. 


\section{Žymèjimai}

\section{Simboliai}

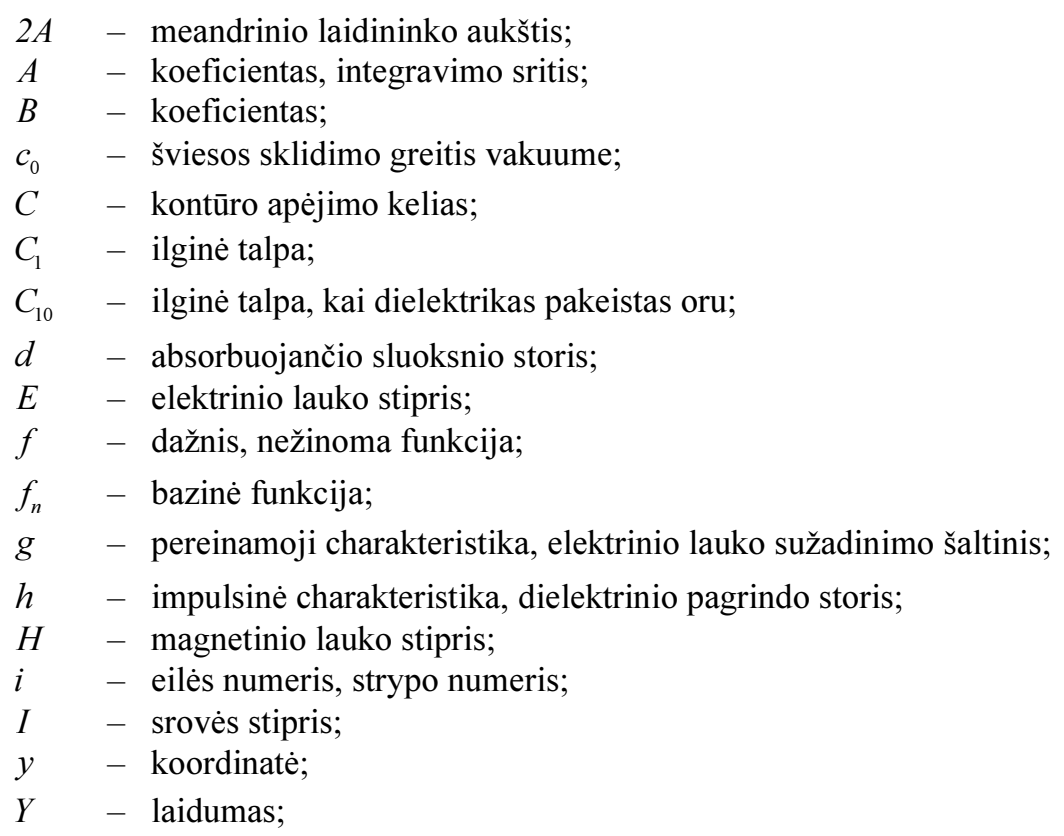




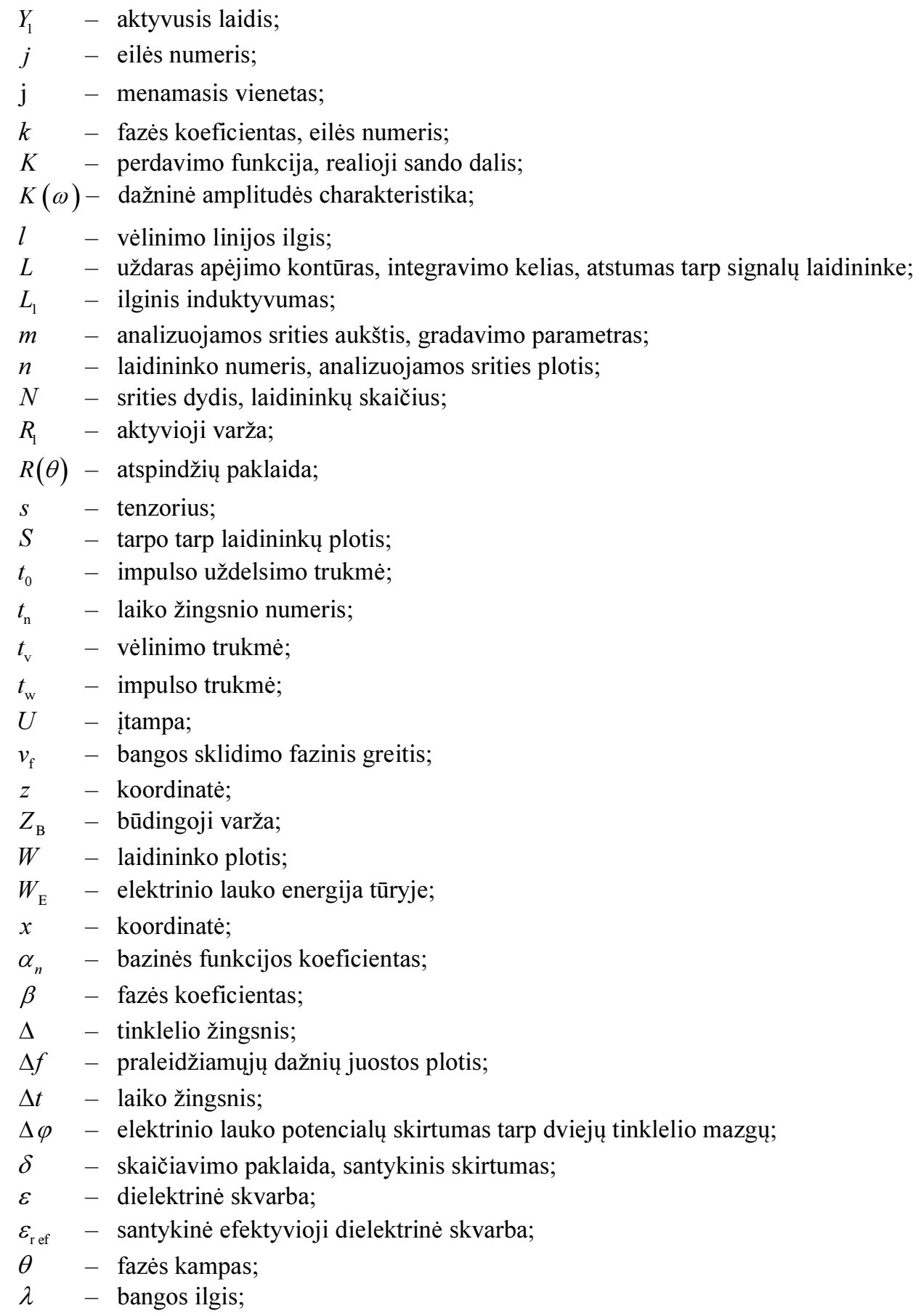




$$
\begin{array}{ll}
\mu & - \text { magnetinė skvarba; } \\
\sigma & - \text { elektrinis laidumas; } \\
\varphi & - \text { elektrinio lauko potencialas; } \\
\varphi(\omega) & - \text { dažninè fazės charakteristika; } \\
\omega & - \text { kampinis dažnis; } \\
\nabla^{2} & - \text { Laplaso operatorius; } \\
{[A]} & - \text { koeficientų retoji matrica; } \\
{[A]^{-1}} & - \text { atvirkštinè koeficientų matrica; } \\
{[B]} & - \text { žinomų mazgų verčių vektorius, magnetinių indukcijų matrica; } \\
{[D]} & - \text { elektrinių indukcijų matrica; } \\
{[E]} & - \text { elektrinio lauko stiprių matrica; } \\
{[H]} & - \text { magnetinio lauko stiprių matrica; } \\
{[\varphi]} & - \text { potencialų matrica; } \\
{[X]} & - \text { nežinomų mazgų verčių vektorius. }
\end{array}
$$

\section{Santrumpos}

BBV

- bėgančios bangos vamzdžiai;

BS metodas

- baigtinių skirtumų metodas;

BSLS metodas

- baigtinių skirtumų laiko srities metodas;

DACh

- dažninè amplitudès charakteristika;

DFCh

- dažninè fazès charakteristika;

DL

- daugialaidè linija;

DLM

- daugialaidžių linijų metodas;

DML

- daugialaidè mikrojuostelinè linija;

$\mathrm{LI}$

- lètinimo itaisas;

LS

- lètinimo sistema;

LKS

- lètinimo ir kreipimo sistema;

MMVL

- meandrinè mikrojuostelinè vèlinimo linija;

MPL

- mikrojuostelinè perdavimo linija;

MOM

- momentų metodas;

TEM

- (angl. transverse electromagnetic wave) skersinè elektromagnetinè banga;

VL $\quad-$ vèlinimo linija. 



\section{Turinys}

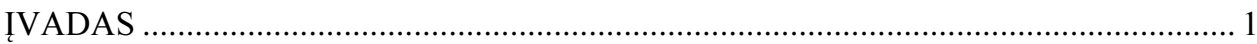

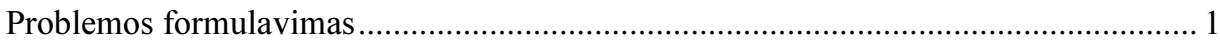

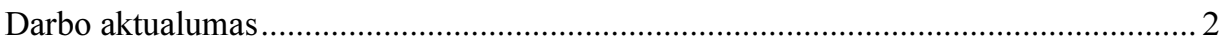

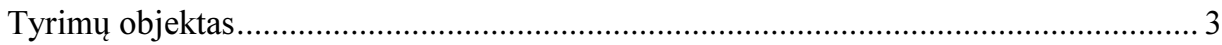

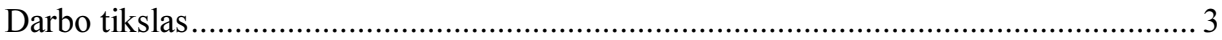

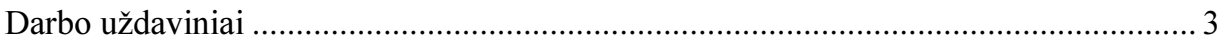

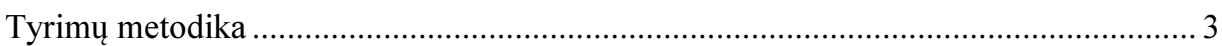

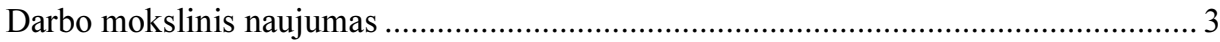

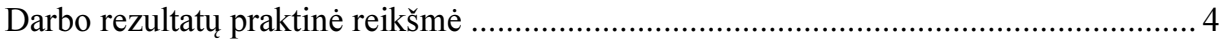

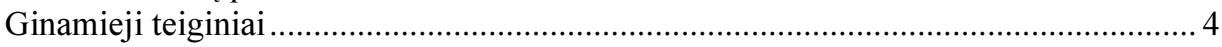

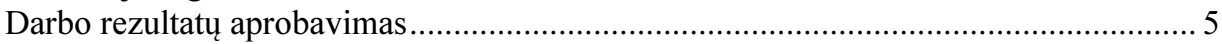

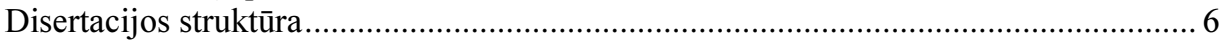

1. LĖTINIMO İTAISŲ SANDAROS IR ANALIZĖS METODŲ APŽVALGA ............... 7

1.1. Lètinimo ịtaisai ir jų taikymo sritys................................................................. 7

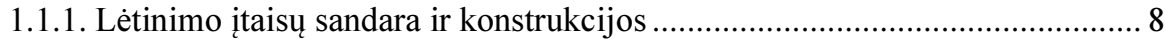

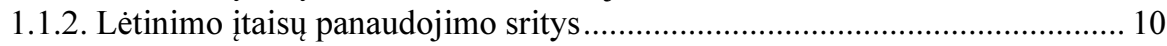

1.1.3. Lètinimo ịtaisų pagrindiniai parametrai ir jų skaičiavimas ........................... 14

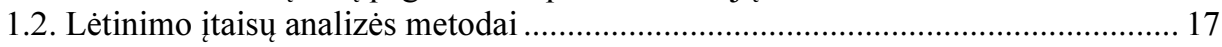

1.2.1. Analitiniai lètinimo ịtaisų analizès metodai............................................. 18

1.2.2. Skaitiniai lètinimo įtaisų analizès metodai................................................ 20

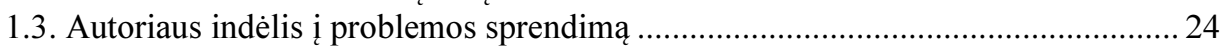


2. MIKROJUOSTELINĖS PERDAVIMO LINIJOS MODELIU SUDARYMAS IR

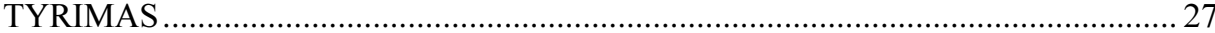

2.1. Mikrojuostelinès perdavimo linijos modelis, grịstas baigtinių skirtumų metodu .. 28

2.1.1. Elektrinių parametrų apskaičiavimo algoritmas................................... 28

2.1.2. Mikrojuostelinès linijos modelio tyrimas ................................................. 34

2.2. Mikrojuostelinès perdavimo linijos modelis, grịstas baigtinių skirtumų laiko

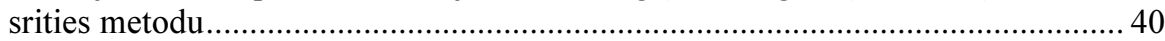

2.2.1. Skaičiavimų algoritmas....................................................................... 40

2.2.1. Mikrojuostelinès linijos modelio tyrimas ............................................. 49

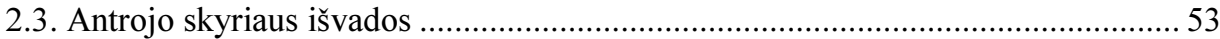

3. DAUGIALAIDE்S MIKROJUOSTELINĖS LINIJOS MODELIO SUDARYMAS IR

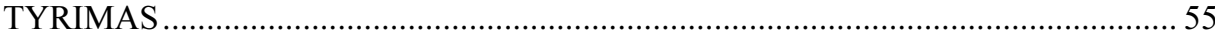

3.1. Susietujų mikrojuostelinių linijų modelis, grịstas baigtinių skirtumų laiko srities

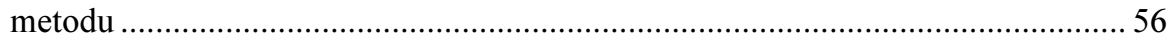

3.1.1. Susietujų mikrojuostelinių linijų modelis ir elektrinių parametrų

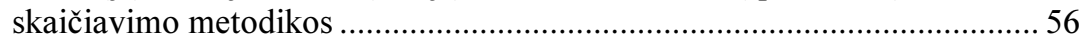

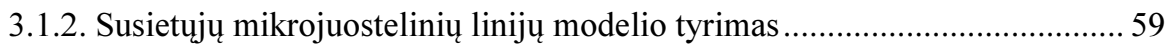

3.2. Daugialaidès mikrojuostelinès linijos modelis, grịstas baigtinių skirtumų laiko

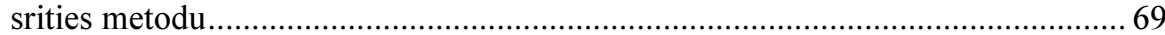

3.2.1. Daugialaidès mikrojuostelinès linijos analizès algoritmas......................69

3.2.2. Daugialaidès mikrojuostelinès linijos modelio tyrimas ......................... 72

3.3. Daugialaidès mikrojuostelinès linijos konstrukcinių parametrų sintezès

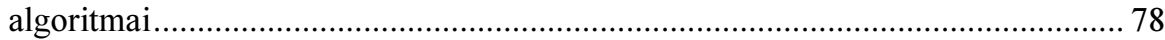

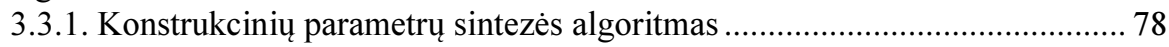

3.3.2. Tolygios būdingosios varžos sintezès algoritmas ................................. 82

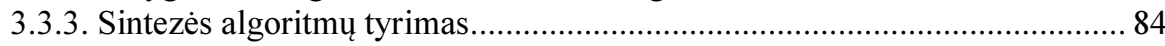

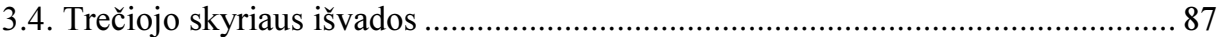

\section{MEANDRINĖS MIKROJUOSTELINĖS VĖLINIMO LINIJOS MODELIŲ}

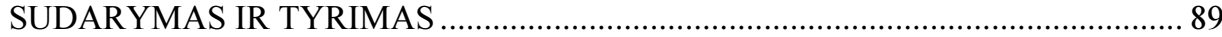

4.1. Meandrinès mikrojuostelinès vèlinimo linijos modelis, grịstas baigtinių skirtumų

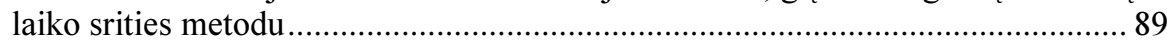

4.1.1. Meandrinès mikrojuostelinès vèlinimo linijos analizès algoritmas ............ 90

4.1.2. Meandrinès mikrojuostelinès vèlinimo linijos modelio tyrimas ................ 94

4.2. Meandrinès mikrojuostelinès vèlinimo linijos modelio, grịsto daugialaidès

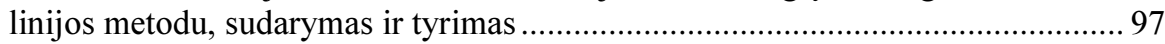

4.2.1. Dviekranès meandrinès mikrojuostelinès vèlinio linijos tyrimo modeliai... 97

4.2.2. Dviekranių meandrinių mikrojuostelinių vèlinimo linijų modeliavimo rezultatai

4.3. Tolygios būdingosios varžos meandrinès mikrojuostelinės vèlinimo linijos sudarymas ir tyrimas 
4.3.1. Tolygios būdingosios varžos meandrinès mikrojuostelinès linijos modelis

4.3.2. Tolygios būdingosios varžos meandrinès mikrojuostelinès linijos modelio tyrimas 106

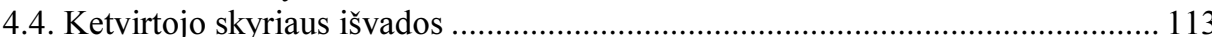

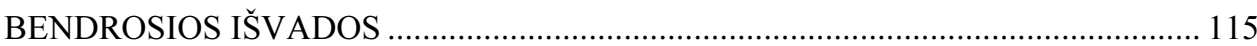

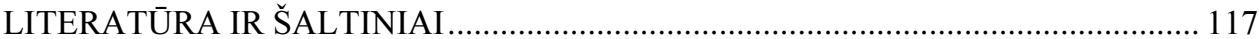

AUTORIAUS MOKSLINIŲ PUBLIKACIJŲ DISERTACIJOS TEMA SĄRAŠAS .... 127 



\section{Contents}

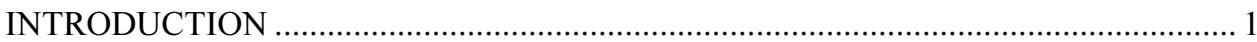

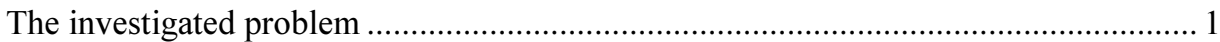

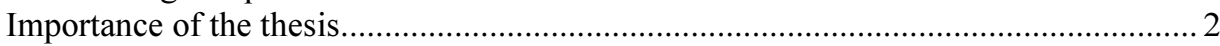

The object of research ……............................................................................... 3

The goal of the thesis............................................................................................. 3

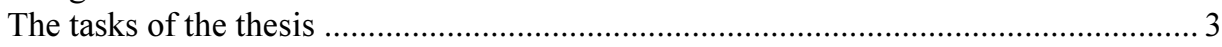

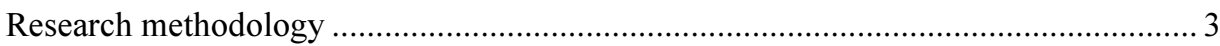

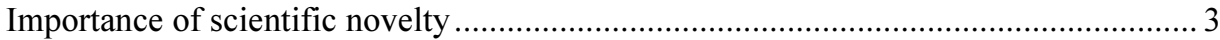

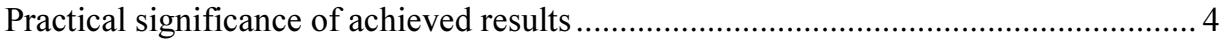

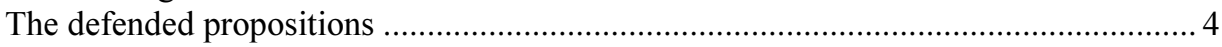

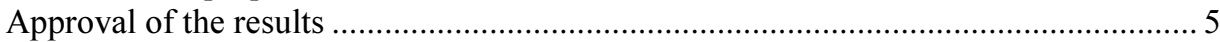

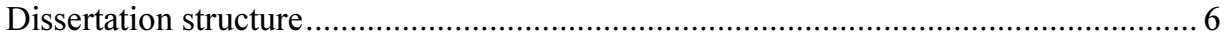

1. REVIEW OF SLOW-WAVE DEVICES STRUCTURES AND THEIR ANALYSIS

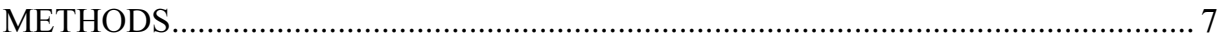

1.1. Scope of applications of slow-wave devices ………….................................. 7

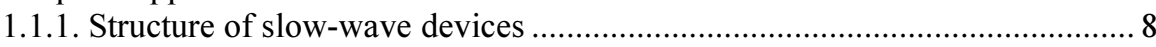

1.1.2. Application areas of slow-wave devices .................................................... 10

1.1.3. Slow-wave devices main parameters ant their calculation............................ 14

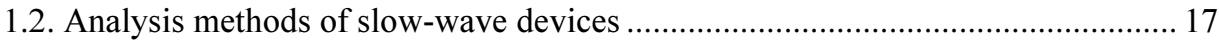

1.2.1. Analytical slow-wave devices analysis methods ...................................... 18

1.2.2. Numerical slow-wave devices analysis methods .......................................... 20 


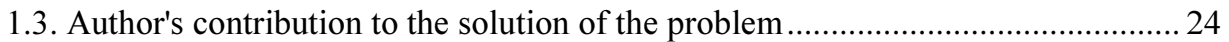

1.4. Conclusions of the chapter 1 and formulation of thesis tasks................................ 24

2. DEVELOPMENT AND INVESTIGATION OF THE MICROSTRIP LINE

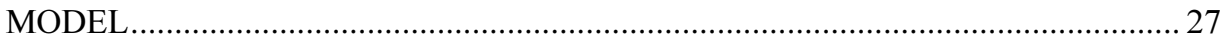

2.1. Investigation of the microstrip line model using finite difference method............ 28

2.1.1. Calculation algorithm of electrical parameters ......................................... 28

2.1.2. Investigation of the microstrip line model .................................................... 34

2.2. Microstrip line model based on finite difference time domain method .................. 40

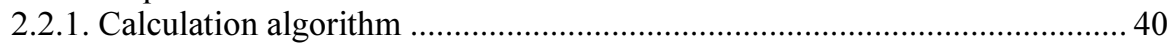

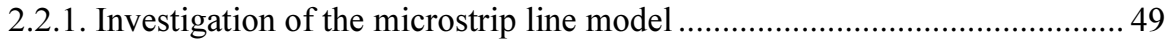

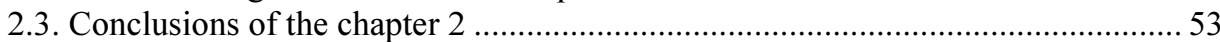

3. DEVELOPMENT AND INVESTIGATION OF THE MULTICONDUCTOR

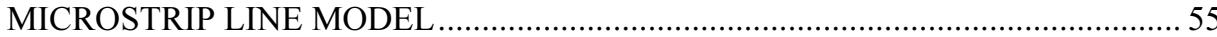

3.1. Coupled microstrip line model based on finite difference time domain method ... 56

3.1.1. Coupled microstrip line model and electrical parameters calculation

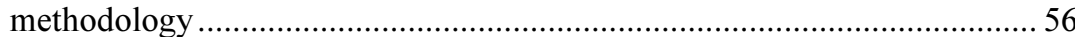

3.1.2. Investigation of the coupled microstrip line model.....................................59

3.2. Multiconductor microstrip line model based on finite difference time domain

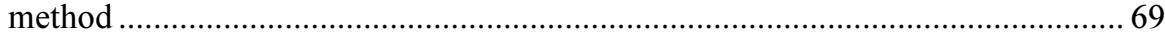

3.2.1. Multiconductor microstrip line analysis algorithm ......................................69 69

3.2.2. Investigation of the multiconductor microstrip line................................... 72

3.3. Synthesis algorithms of the multiconductor microstrip line structure parameters 78

3.3.1. Synthesis algorithm of structure parameters ……….................................. 78

3.3.2. Synthesis algorithm of uniform characteristic impedance .......................... 82

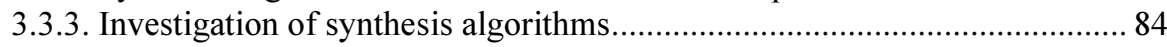

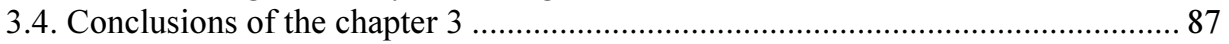

4. DEVELOPMENT AND INVESTIGATION OF THE MEANDER MICROSTRIP

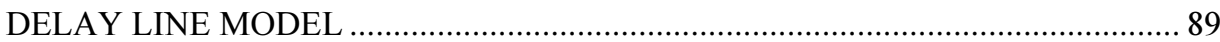

4.1. Development and investigation of the meander microstrip delay line model using finite difference time domain method .............................................................. 89

4.1.1. Synthesis algorithm of the two-shielded meander microstrip delay line ..... 90

4.1.2. Investigation of meander microstrip delay line model.................................. 94

4.2. Development and investigation of the meander microstrip delay line model using

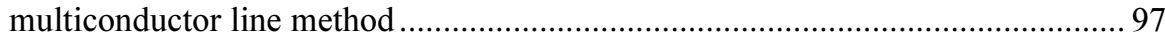

4.2.1. Investigation model of the meander microstrip delay line ........................... 97

4.2.2. Investigation results of the two-shielded meander microstrip delay line

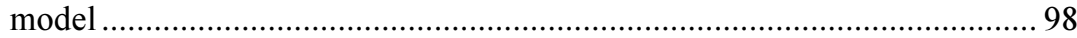

4.3. Development and investigation of uniform characteristic impedance meander microstrip delay line 104

4.3.1. Model of uniform characteristic impedance meander microstrip delay line 
4.3.2. Investigation of uniform characteristic impedance meander microstrip delay line ......

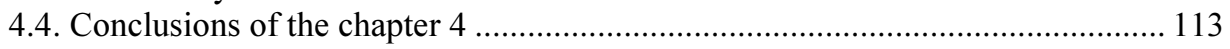

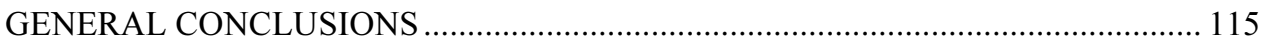

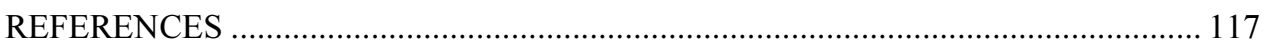

LIST OF THE AUTHOR'S SCIENTIFIC PUBLICATIONS RELATED TO THE

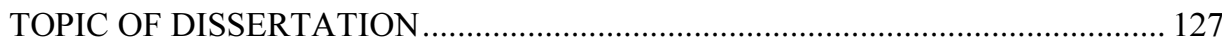





\section{Ivadas}

\section{Problemos formulavimas}

Periodinès ar kvazi-periodinès sandaros elektrodinaminių lètinimo sistemų (LS) modeliavimui plačiausiai naudojamas daugialaidžių linijų (DL) metodas. Šis metodas leidžia gauti svarbiausių LS parametrų: lètinimo koeficiento (arba vèlinimo trukmès) ir būdingosios varžos dažnines priklausomybes. Šiuo atveju žinant ị LS siunčiamo signalo dažninį spektrą, taikant atvirkštinę Furjè (angl. Fourier) transformaciją, galima gauti signalo LS išèjime formą ir tokiu būdu ivertinti signalo iškraipymus.

Didžiausias DL metodo privalumas - palyginus nedideli reikalavimai kompiuterio ištekliams igyvendinant tam tikros LS matematini modeli kompiuterine programa. DL metodo trūkumas - LS šiuo atveju traktuojama kaip begalinè, taigi neịvertinamas LS galinių laidininkų netolygumas. Taip pat sudètinga ịvertinti LS sudarančių laidininkų kraštus jungiančių jungiklių įtaka LS elektrinèms charakteristikoms.

Taikant LS modeliavimui skaitinius baigtiniu skirtumu (BS) ir baigtiniu skirtumų laiko srities (BSLS) metodus galima tiksliai įvertinti ir baigtinį LS dydị (galinių laidininku efektą) ir jungiklių ịtaką (kraštų efektą) LS savybėms. Laiko srities metodo trūkumai: a) sudetinga sudaryti idealiai sugeriančias ribines sąly- 
gas; b) dideli poreikiai kompiuterio išteklių (ypač procesoriaus darbo laiko ir atminties talpos).

Disertacijoje sprendžiama LS kraštinių ir galinių laidininkų įtakos modelių tikslumui įvertinimo problema.

\section{Darbo aktualumas}

Lètinimo sistemos plačiai taikomos įvairios paskirties mikrobangu įtaisuose: antenose, filtruose, faziniuose keitikliuose ir šakotuvuose, vèlinimo linijose, analoginio signalų apdorojimo ittaisuose ir kt. Šiose sistemose dažniausiai taikomos spiralinès arba meandrinès sandaros LS, kurių tyrimui taikomi analitiniai, skaitiniai arba hibridiniai metodai.

Lètinimo sistemų projektavimas prasidejo nuo analitinių metodų panaudojimo, t. y. grandinių ir ilgụjų linijų teorijos taikymo ir nuo XX a. aštunto dešimtmečio, atsiradus didiesiems kompiuteriams (angl. mainframe computers), prasidejjo intensyvesni LS tyrimai. Analitiniais metodais buvo nagrinejjamos paprastesnès LS konstrukcijos, be to nebuvo atsižvelgiama i daugeli fizikinių veiksnių. Sukurti skaitiniai metodai leidžia nagrinèti sudètingų konstrukcijų LS, tačiau, dèl mažų tuometinių skaičiavimo pajègumų, ilga sprendimo trukmè leido analizuoti tik palyginti mažas, nesudètingas struktūras. Šių struktūrų analizė leido sukurti naujus modelius ir skaitinius metodus, leidžiančius greičiau ir tiksliau ivvertinti LS charakteristikas. Pirmieji komerciniai elektromagnetinių laukų sprendimo ir LS projektavimo programų paketai sukurti po kelių dešimtmečių, paplitus darbo stotims ir asmeniniams kompiuteriams. XX a. pabaigoje spartesni kompiuteriai ir efektyvesne programine įranga leido optimizuoti planarines LS struktūras. Pastaraisiais metais LS analizei bei sintezei pradèti taikyti hibridiniai metodai - kelių metodų kombinacija (dirbtinių neuronų tinklų, neraiškiosios logikos, analitinių ir skaitinių metodų).

Tenkinant telekomunikacijų, signalų apdorojimo ir kitų mokslo ir pramonès sričiu poreikius nuolat kuriamos naujos elektronines sistemos, veikiančios vis aukštesnio dažnio radijo bangų diapazone, dèl šios priežasties būtina tobulinti LS ir jų struktūrų modelius. Kuriant naujus LS modelius būtina atsižvelgti ị šiose sistemose taikomų lètinimo ịtaisų konstrukcijų netolygumus, dèl kurių susidaro nepageidaujami signalų atspindžiai, kurių pasekmé - siaurèja lètinimo sistemos ir viso įtaiso, kuriame jos naudojamos, darbo dažnių sritis. Todẻl tikslinga ieškoti naujų lètinimo sistemų konstrukcijų, leidžiančių praplèsti darbo dažnių sriti bei sumažinti šioje sistemoje esančius nepageidaujamus signalų atspindžius.

Skaičiavimo technikos pajègumai ir galimybès nuolat didejja, tačiau esamos LS analizès bei sintezès metodikos ir algoritmai neleidžia greitai ir efektyviai surasti lètinimo sistemų parametrus. Todèl yra aktualu ieškoti naujų automati- 
zuoto lètinimo sistemų analizès bei sintezès metodų, leidžiančių sumažinti šių sistemų projektavimo trukmę.

\section{Tyrimų objektas}

Darbo tyrimų objektas - daugialaidžių ir meandrinių mikrojuostelinių linijų matematiniai modeliai.

\section{Darbo tikslas}

Šio darbo tikslas - sukūrus modelius, grịstus baigtinių skirtumų laiko srities metodu, ištirti galinių ir kraštinių laidininkų netolygumų įtaką meandrinių mikrojuostelinių vėlinimo linijų laiko ir dažnio charakteristikoms, pasiūlyti meandrinių vèlinimo linijų konstrukcijų tobulinimo priemones.

\section{Darbo uždaviniai}

Tikslui pasiekti darbe reikia spręsti šiuos uždavinius:

1. Sudaryti modelius ir ištirti pavienès, susietujų ir daugialaidžių mikrojuostelinių linijų laiko ir dažnines charakteristikas, taikant baigtinių skirtumų bei baigtinių skirtumų laiko srities analizès metodus.

2. Sudaryti tolygios būdingosios varžos daugialaidžių mikrojuostelinių linijų sintezès ir meandrinių mikrojuostelinių vèlinimo linijų analizès algoritmus bei jų laiko ir dažninių charakteristikų skaičiavimo metodikas.

3. Imitacinių skaičiavimų būdu patikrinti siūlomų LS parametrų skaičiavimo metodų veiksmingumą ir efektyvumą.

\section{Tyrimų metodika}

Darbe taikomi elektrodinaminio uždavinio sprendimo metodai, pritaikyti lètinimo sistemų analizei ir sintezei - tai daugialaidžių linijų, skaitiniai laiko ir dažnio srities metodai. LS kompiuteriniai modeliai ir sukurtieji algoritmai igyvendinti naudojant programavimo kalbą $\mathrm{C}, \mathrm{C}++$, taip pat taikant programų paketą Mat$\mathrm{lab}^{\circledR}$ bei specialios paskirties programų paketus CST Microwave Studio ${ }^{\circledR}$ ir Sonnet $^{\circledR}$.

\section{Darbo mokslinis naujumas}

Rengiant disertaciją buvo gauti šie elektros ir elektronikos inžinerijos mokslui svarbūs nauji rezultatai: 
1. Sukurti baigtinių išmatavimų mikrojuostelinių perdavimo struktūrų modeliai, grịsti baigtinių skirtumų ir baigtinių skirtumų laiko srities metodais, bei ištirtos šių struktūrų elektrinès charakteristikos plačiame dažnių ruože.

2. Taikant daugialaidžių linijų, baigtinių skirtumų ir baigtinių skirtumų laiko srities metodus, sukurti ir igyvendinti algoritmai, leidžiantys ištirti meandrinių lètinimo sistemų (LS) galinių laidininkų ịtaką dažninėms charakteristikoms, kurių rezultatai panaudoti meandrinès tolygios būdingosios varžos LS sintezei.

3. Sudarytas meandrinès mikrojuostelinès lètinimo sistemos matematinis modelis, grịstas baigtinių skirtumų laiko srities metodu, leidžiantis ịvertinti LS kraštinių ir galinių laidininkų netolygumų ịtaką sistemos dažninèms charakteristikoms.

\section{Darbo rezultatų praktinè reikšmè}

Sudarytos analizès ir sintezès skaičiavimo metodikos, leidžiančios projektuoti lètinimo sistemas, ivvertinant sistemose esančius netolygumus - galinių ir kraštinių laidininkų įtaką LS savybėms. Sudaryti daugialaidžių linijų bei baigtinių skirtumų laiko srities metodais grịsti lètinimo sistemų dažninių charakteristikų skaičiavimo algoritmai, leidžiantys sumažinti LS projektavimo proceso trukmę. Sudarytieji modeliai ir pasiūlytieji algoritmai igyvendinanti naudojant $\mathrm{C}, \mathrm{C}++$ programavimo kalbas bei programų sistemą Matlab $^{\circledR}$ ir yra taikytini automatizuotose vėlinimo liniju projektavimo sistemose, siekiant padidinti analizès tikslumą ir pagerinti projektuojamų ịtaisų charakteristikas.

\section{Ginamieji teiginiai}

1. Sudarytasis meandrinès mikrojuostelinès vèlinimo linijos modelis, grịstas baigtinių skirtumų laiko srities metodu, leidžia įvertinti elektromagnetinio lauko sklaidos kraštiniuose ir galiniuose laidininkuose įtaką analizuojamų linijų charakteristikoms ir atskleide, kad galinių ir reguliariosios srities strypų būdingoji varža gali skirtis daugiau negu $15 \%$.

2. Pasiūlytasis daugialaidžių mikrojuostelinių linijų sintezès algoritmas leidžia suprojektuoti liniją, kurios signalinių laidininkų būdingosios varžos vertès skiriasi mažiau negu $1 \%$.

3. Meandrinès mikrojuostelinès vélinimo linijos, suprojektuotos pagal tolygios būdingosios varžos daugialaidès linijos modelị, pralaidumo juosta iki $20 \%$ platesnè negu linijos, suprojektuotos pagal periodinès daugialaidès linijos modeli. 
4. Daugialaidès mikrojuostelinès linijos, veikiančios sinfazinių arba priešfazinių normaliụjų bangų režimu, visais laidininkais sklindančių signalų vèlinimo trukmè skiriasi mažiau negu $1 \%$ plačiame dažnių diapazone.

\section{Darbo rezultatų aprobavimas}

Disertacijos tema yra atspausdinti 7 moksliniai straipsniai: trys - mokslo žurnaluose, itrauktuose i ISI Web of Science sąrašą (Pomarnacki et al. 2010; Krukonis, Urbanavičius 2011; Krukonis et al. 2013); trys - mokslo žurnaluose, cituojamuose Lietuvos mokslų tarybos patvirtintose duomenų bazèse (Krukonis et al. 2010 - 2012), vienas - recenzuojamoje tarptautinès konferencijos medžiagoje (Krukonis, Urbanavičius 2012).

- Pomarnacki, R.; Krukonis, A.; Urbanavičius, V. 2010. Parallel Algorithm for the Quasi-TEM Analysis of Microstrip Multiconductor Line, keturioliktoji tarptautinè konferencija „Elektronika 2010“. Vilnius, 2010 m. gegužès $18-20 \mathrm{~d}$.

- Krukonis, A. 2010. Tolygaus charakteringojo impedanso mikrojuostelinès daugialaidès linijos sintezès algoritmas, tryliktoji respublikinè Lietuvos jaunujų mokslininkų konferencija „Mokslas - Lietuvos ateitis“. Vilnius, $2010 \mathrm{~m}$. kovo $19 \mathrm{~d}$.

- Krukonis, A. 2011. Mikrojuostelinių perdavimo linijų dispersinès savybės, keturioliktoji respublikiné Lietuvos jaunujų mokslininkų konferencija „Mokslas - Lietuvos ateitis“. Vilnius, $2011 \mathrm{~m}$. kovo $19 \mathrm{~d}$.

- Krukonis, A.; Urbanavičius, V. 2011. Unclosed Microstrip Line Modelling Using FDTD Method, penkioliktoji tarptautinè konferencija „Elektronika 2011“. Vilnius, $2011 \mathrm{~m}$. gegužès 17-19 d.

- Krukonis, A.; Urbanavičius, V. 2011. MMCL Model Development Using FDTD Technique, tarptautinis seminaras ,Microwave and LightWave Systems“. Vilnius, $2011 \mathrm{~m}$. gruodžio $2 \mathrm{~d}$.

- Krukonis, A.; Mikučionis, Š. 2012. Susietųjų linijų nevienalytejje terpèje modelis, grịstas BSLS metodu, penkioliktoji respublikine Lietuvos jaunujų mokslininkų konferencija „Mokslas - Lietuvos ateitis“. Vilnius, $2012 \mathrm{~m}$. kovo $16 \mathrm{~d}$.

- Krukonis, A., Urbanavičius, V. 2012. Multiconductor microstrip line modelling using FDTD method. XXII International Conference on Electromagnetic Disturbances „EMD2012“. Vilnius, $2012 \mathrm{~m}$. rugsèjo 20-21 d.

- Krukonis, A. 2013. Impedanso netolygumo itaka meandrinių mikrojuostelinių vẻlinimo linijų charakteristikoms, šešioliktoji respublikinė Lietuvos jaunuju mokslininkų konferencija „Mokslas - Lietuvos ateitis“. Vilnius, $2013 \mathrm{~m}$. kovo $15 \mathrm{~d}$. 


\section{Disertacijos struktūra}

Disertaciją sudaro ịvadas, keturi skyriai, kitų autorių ir autoriaus literatūros sąrašai, bendrosios išvados.

Darbo apimtis yra 128 puslapiai, tekste panaudota 70 numeruotu formulių, 53 paveikslai ir 18 lentelių. Rašant disertaciją buvo panaudota 115 literatūros šaltinių. 


\section{1}

\section{Lètinimo ịtaisų sandaros ir analizès metodų apžvalga}

Šiame skyriuje apžvelgiamos lètinimo įtaisų konstrukcijos, jų taikymo sritys, vystymosi tendencijos bei sprendžiamos lètinimo itaisu tyrimo ir projektavimo problemos. Nagrinejami skaitiniai, analitiniai, hibridiniai analizès metodai ir jų taikymas lètinimo įtaisų projektavimo uždaviniams spręsti, formuluojamas disertacinio darbo tikslas ir uždaviniai.

\subsection{Lètinimo ịtaisai ir jų taikymo sritys}

Lètinimo itaisas (LI) - tai ịtaisas, kuriame elektromagnetinès bangos sklidimo greitis $v_{\mathrm{f}}$ daug mažesnis už šviesos greitį vakume $c_{0}$ ir bendruoju atveju tokio ịtaiso paskirtis yra elektromagnetinès bangos uždelsimas tam tikrai laiko trukmei (Vainoris 2004). LI plačiau pradèti nagrinèti nuo XX a. penktojo dešimtmečio pradžios, kai buvo sukurta bėgančiosios bangos elektroninio vamzdžio sistema. Lietuvoje LI tyrimus pradejjo prof. Vainorio vadovaujama mokslininku grupè, kuri sukūrè vieningą $L I$ İ analizès teoriją, ištyrè ir palygino daugelio LI charakteristikas ir savybes (Вайнорис et al. 1986). Prie elektrodinaminių LI tyrimo ir jų taikymo elektroniniuose įtaisuose problemų sprendimo daug prisidèjo profesoriai S. Štaras, R. Kirvaitis, L. Nickelson, R. Martavičius, J. Skudutis, 
V. Urbanavičius, docentai A. Gurskas, A. Jurjevas, V. Daškevičius, R. Pamarnacki, A. Katkevičius ir kiti. LI teoriniai ir eksperimentiniai tyrimai, ju gamybos ir taikymo problemos apibendrintos monografijoje (Štaras et al. 2012).

\subsubsection{Lètinimo ịtaisu sandara ir konstrukcijos}

Bendruoju atveju elektromagnetinè banga lètinimo ịtaisuose sklinda laidininkų ir dielektrikų visumoje. Atsižvelgus ị dielektrinès terpès sandarą LI gali būti vienalyčiai arba nevienalyčiai, pagal laidininkų išsidèstymo reguliarumą periodiniai arba neperiodiniai. Pagal taikymo sritis LI galima klasifikuoti ị lètinimo sistemas (LS), lètinimo ir kreipimo sistemas (LKS), vèlinimo linijas (VL) ir kitus lètinimo itaisus.

Mikrobanginių virpesių stiprintuvuose ir generatoriuose plačiai taikomos bėgančiosios ir atbulinès bangos elektroninių lempu sistemos, kuriose elektronų pluoštas sąveikaudamas su LS elektromagnetinès bangos, sklindančios šiek tiek léčiau negu elektronai, elektriniu lauku, igauna papildomos energijos. Bègančiosios ir atbulinès bangos lempose taikomos spiralinès, meandrinès, simetrinès ir nesimetrinès lètinimo sistemos (Štaras, Skudutis 1999; Sroka 2003). Šios lempos paverčia nuolatinę elektros srovès energiją i aukšto dažnio virpesių energiją, o ši transformacija pasiekiama panaudojant lètinimo įtaisą, kuris sukuria elektrinị lauką su stipria išilgine komponente, lygiagrečia elektronu judejjimo krypčiai. Nanosekundinių ir pikosekundinių impulsų bei kitų plataus dažninio spektro signalų registravimui ir stebejimui naudojami oscilografiniai bėgančiosios bangos vamzdžiai (BBV). Šiuose vamzdžiuose elektronų spindulys kreipiamas elektromagnetinès bangos, sužadinamos lètinimo ir kreipimo sistemoje, skersiniu elektrinio lauko sandu. BBV plačiai praleidžiamujų dažnių juostai užtikrinti LKS elektromagnetinès bangos greitis turi sutapti su elektronų spindulio greičiu. Kaip LKS gali būti taikomi tik nulinio krizinio dažnio LI, pvz. mikrojuostelinès linijos, spiralinès ir meandrinès sistemos (Štaras, Burokas 2006; Daškevičius et al. 2007).

Plačia praleidžiamujų dažnių juosta turi pasižymèti taip pat ir vẻlinimo linijos. VL paskirtis - uždelsti ja sklindanti signalą nustatytai trukmei, ženkliai neiškraipant delsimo signalo. Šiam tikslui pasiekti VL dažninès amplitudès charakteristikos (DACh) netolygumas signalo spektro ribose neturi viršyti $3 \mathrm{~dB}, \mathrm{o}$ vèlinimo trukmès dispersija turi būti tokia, kad dažninès fazès charakteristikos nukrypimas nuo tiesinès aukščiausiuose dažniuose neviršytų 0,35 radiano (Вайнорис et al. 1986).

Iš kitu lètinimo itaisų panaudojimo atveju galima išskirti planarinès konstrukcijos LI panaudojimą antenose, filtruose, rezonatoriuose, dispersinèse sistemose. Planariniai LI - tai plokščios konstrukcijos lètinimo įtaisai, gaminami pagal integrinių grandynų technologijas. Šia technologija lengvai suformuojama 
ịvairių konstrukcijų meandriniai, juosteliniai bei mikrojuosteliniai lètinimo įtaisai. Paskutiniame dvidešimtmetyje mažos galios elektronikos įtaisuose plačiausiai naudojamos meandrinès ir kitokios planarinès lètinimo sistemos. Tokių įtaisų konstrukcija santykinai nesudètinga: itaisą sudaro meandro formos laidininkas, suformuotas ant vienos dielektrinio pagrindo pusès, ir ištisinis laidus ekranas, esantis ant kitos dielektrinio pagrindo pusès. Sudètingesnès yra daugiasluoksnių planarinių LI gamybos technologijos (Hu, Xu 2009). Skirtingu konfigūracijų meandrinès lètinimo įtaisai pateikti (Kirvaitis 1994; GaWon et al. 2008) darbuose.

Atradus aukštatemperatūrius superlaidininkus (angl. high temperature superconductors - HTS), atsirado galimybè sukurti miniatiūrinius lètinimo įtaisus su labai plačia praleidžiamujjų dažnių juosta. Nuo 1986 m. padidèjo susidomèjimas ir darbų gausa su šių laidininkų pritaikymu ịvairiuose lètinimo įtaisuose (Liang et al. 1993; Yi et al. 2004). Didžiausias superlaidžių medžiagu pranašumas yra mažas jų paviršiaus pasipriešinimas, pasireiškiantis žemiau pereinamosios temperatūros. Tai leidžia gaminti aukštos kokybès planarinius lètinimo įtaisus. 1.1 paveiksle pateiktas vienas iš aukštos temperatūros superlaidininkinès vèlinimo linijos struktūrų eskizas.

Signalas susilpneja sklisdamas perdavimo linija, dèl nuostoliu laidininke ir dielektrike. Superlaidžiosios perdavimo linijos leidžia išvengti didesnio signalo

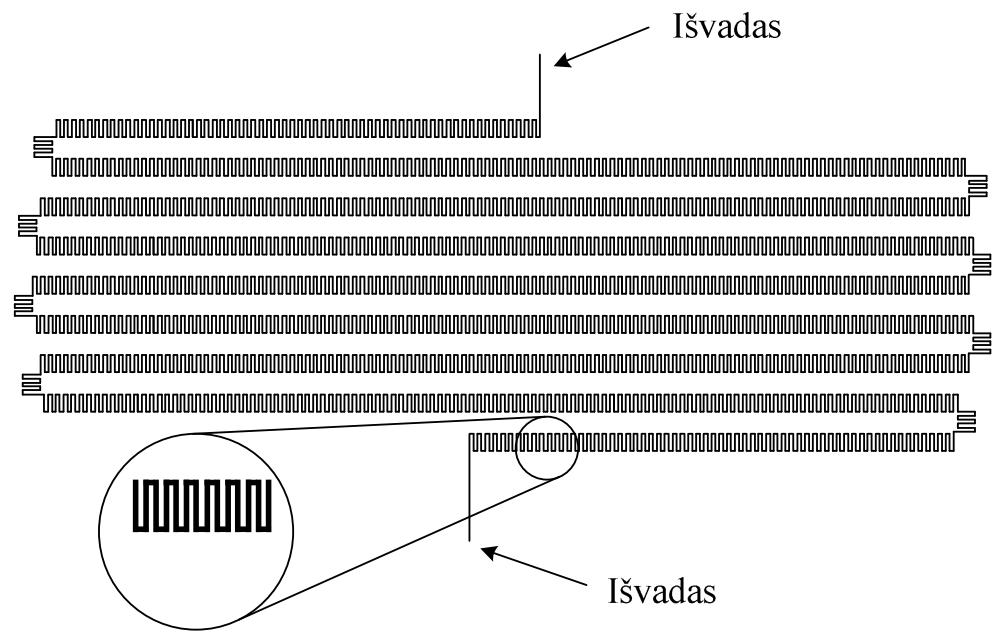

1.1 pav. Aukštatemperatūrio superlaidininko dvigubos meandrinès vèlinimo linijos struktūros eskizas (Tiong et al. 2008)

Fig. 1.1 The geometry of high temperature superconductor double spiral meander delay line (Tiong et al. 2008) 
susilpnejjimo. Šias linijas galima suskirstyti ị meandrines linijas, dvigubas spiralines linijas ir vienetinès ląstelès struktūras. Superlaidžiosios vélinimo linijos gali būti pritaikytos karinejje elektronikoje ir radarų sistemose, tokiose kaip momentinio dažnio matavimo posistemèse, dažniu moduliuotos nepertraukiamos bangos (angl. Frequency modulated continuous wave - FMCW) radaruose bei kitose signalo saugojimo ir apdorojimo sistemose (Tiong et al. 2008). Magnetiškai perderinami superlaidieji rezonatoriai ir filtrai pasižymi žemais įejjimo nuostoliais ir aukštu perderinimu. Šių ịtaisų kūrimui reikalingi programiniai įrankiai, kurie leidžia tiksliai modeliuoti struktūras atsižvelgiant ị laidininko ir dielektrinio sluoksnio nuostolius, pagrindo anizotropija, ypač aukštos temperatūros superlaidininkų sluoksnių mikrobangų charakteristikas ir įmagnetinto ferito anizotropiją (Kolmakov et al. 2002).

Atsiradus dirbtiniams dielektrikams (metamedžiagoms), nuo pirmųų darbų (Eleftheriades et al. 2002; Lai et al. 2004) kilo susidomejjimas dèl jų pritaikymo mikrobangu ịtaisuose. Metamedžiaginiai dielektrikai turi natūraliai gamtoje esančiose medžiagose neatsirandančias elektromagnetines savybes, pavyzdžiui: neigiama skvarba. Metamedžiaginès vèlinimo linijos skirtos dirbti plačiame dažnių ruože su mažais įèjimo nuostoliais ir leidžia kontroliuoti vèlinimo trukmę keičiant valdymo įtampą (Chen et al. 2006; Wenjia, Hongjoon 2009). Darbuose (Abielmona et al. 2007; Borja et al. 2011) autoriai pademonstravo dešininès/kairinès vélinimo linijas ir kooplanarinę perdavimo liniją, kurios dirba plačiame dažnių ruože. Pritaikius šio tipo LI antenose, gaunamas platesnis praleidžiamųjų dažnių diapazonas, didesnis efektyvumas ir geresnis suderinamumas (Niu 2010).

Apibendrinus galima teigti, kad kuriant ivvairios sandaros planarinius LI plačiai naudojami naujausi dielektrikai ir laidininkai. Pažymètina, kad letinimo įtaisuose naudojami ne tik vienalyčiai dielektrikai, tačiau ir jų sluoksnių bei formų kombinacijos (Nara, Koshiji 2006; Horii et al. 2005).

\subsubsection{Lètinimo ịtaisų panaudojimo sritys}

Plataus dažniu spektro $(\Delta f>1 \mathrm{GHz})$ ir didèlès galios $(P>50 \mathrm{~W})$ mikrobangų virpesiams generuoti ir stiprinti plačiai taikomos bėgančiosios ir atbulinės bangos elektroninès lempos, kurių veikimas gristas LS elektrinio lauko savybèmis. Bègančiosios ir atbulinès bangos lempos šiuo metu naudojamos komercinèje bei karinejje elektronikoje, matavimo įtaisuose, radarų sistemose (Manz 2009).

LS iš neiprasto pritaikymo pavyzdžiu galima paminèti elektromagnetinę patranką, kurios modeliavimas, atskirų konstrukcijos elementų tobulinimas šiuo metu intensyviai vykdomas daugelyje šaliu (Ulisse et al. 2012; Pinto et al. 2011; Yu-xiang et al. 2012). Karo pramonès elektroninès apsaugos (angl. electronic counter measures) ir elektroninio karo (angl. electronic warfare) sistemose tai- 
komos bėgančios ir atbulinès bangos lempos, kurios veikia plačiame dažnių diapazone ir yra didelès galios: $200 \mathrm{~W}, 6-18 \mathrm{GHz}$ bei $80 \mathrm{~W}, 18-40 \mathrm{GHz}$ (Trani, Antoine 2012). Šiose sistemose, taip pat pilotuojamuose ir bepiločiuose lèktuvuose taikomų bėgančios ir atbulinès bangos lempos reikalavimai: minimalūs matmenys ir svoris, didelis efektyvumas, veikimas didesniame dažnių ir temperatūros ruože bei veikimas dideliame aukštyje.

Bègančios ir atbulinès bangos lempos panaudojamos komercinèse palydovinèse komunikacijų sistemose: antžeminèse komunikacijų sistemose ir palydovuose. Ilgaamžiškumas (tarnavimo laikas didesnis nei 20 metų), mažas energijos suvartojimas, didelis patikimumas, efektyvumas ir atsparumas perkrovoms svarbūs bėgančios ir atbulinès bangos lempos parametrai tokiose sistemose. Šioms sistemoms skirtas bėgančios ir atbulinès bangos lempas gamina Thales imonè, kuri užima didelę rinkos dali (Coaker, Challis 2008).

Bègančios ir atbulinès bangos lempos taikomos submilimetriniu bangu ir $\mathrm{THz}$ dažnio ruožo stiprintuvuose, generatoriuose, siekiama sukurti konstrukcijas, kurios leistų aparatūrai veikti stabiliai platesniame dažnio diapazone (Kotiranta et al. 2010; Huarong et al. 2013).

Nors bėgančios ir atbulinès bangos lempos šiuo metu yra plačiai taikomos, tačiau lieka spręstinų ir tobulintinų klausimų. Tai rodo gausa straipsnių, kuriuose nagrinejjamos bėgančios ir atbulinės bangos lempos spiralinio laidininko struktūros įtaka dažninèms charakteristikoms (Štaras, Burokas 2006), atskirų bėgančios ir atbulinès bangos lempos struktūros elementų tobulinimas (Yanyan et al. 2012; Wujian et al. 2012), galios didinimas 18-40 GHz darbo dažnių diapazone (Chong et al. 2012) ir kt.

Planariniai meandriniai lètinimo įtaisai yra plačiausiai taikomi antenose, kurios naudojamos mažų gabaritinių matmenų ir mobiliuose įrenginiuose. Šios antenos vis daugiau taikomos belaidžio lokalaus tinklo (angl. wireless local area network - WLAN) sistemose, saugumo ir kontrolès įrenginiuose, kuriuose naudojamos identifikavimo radijo bangomis sistemos (angl. radio frequency identification - RFID) (Bentaher et al. 2011). Antenos dydis efektyviai sumažinamas antenos dipoliui panaudojant meandro formos laidininką, todel tokio tipo antenos integruojamos didelio integracijos laipsnio ir mažu gabaritu sistemose, be to šias antenos patrauklios dèl kompaktiško dydžio, žemo profilio, lengvos gamybos ir mažos kainos. Meandrinių antenų rezonansinis dažnis mažesnis nei tokio paties ilgio pasyvinių antenų. Nuo meandrų kilpų skaičiaus priklauso antenos efektyvumas, o nuo tarpo tarp meandru priklauso rezonansinis antenos dažnis didèjant tarpui, rezonansinis dažnis sumažeja (Ambhore, Dhande 2012). Nors meandrinès antenos praleidžiamujų dažnių juosta siauresnè nei ištisos antenos, tačiau jos turi ir kitą privalumą - tai dviguba dažnio pralaidumo juosta (Jahanbakhshi et al. 2012). Šiuo metu siekiama sukurti įvairias meandrinių antenų konstrukcijas, kurios dirbtų viename ar keliuose dažnių diapazonuose ir turètų 
mažus grižtamuosius nuostolius. Darbe (Misman et al. 2008) pristatoma lokalaus belaidžio tinklo antena, veikianti $2,4 \mathrm{GHz}$ dažnio diapazone (1.2 pav.). Ši antena turi $80 \mathrm{MHz}$ pralaidumo juosta ir mažus grižtamuosius nuostolius: $-37,7 \mathrm{~dB}$. Intensyviai tobulinamos dvigubos praleidžiamujų dažnių juostos meandrinių antenų konstrukcijos, darbe (Jamil et al. 2011) pristatoma didelio duomenų pralaidumo ir plačios dvigubos praleidžiamųu dažnių juostos antena: 2,291-2,553 GHz ir 5,141-5,874 GHz.

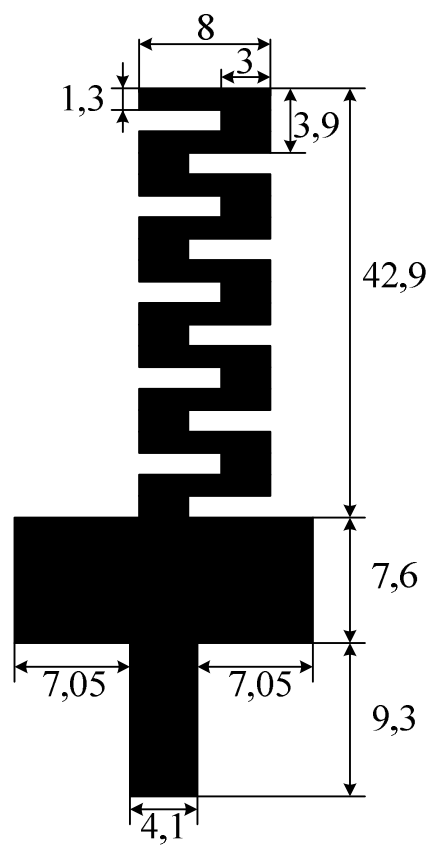

1.2 pav. Planarinès meandrinès $2,4 \mathrm{GHz}$ antenos struktūra ir matmenys milimetrais (Misman et al. 2008)

Fig. 1.2 Layout with dimensions of planar meander $2.4 \mathrm{GHz}$ antenna (Misman et al. 2008)

LI panaudojami ne tik kaip pačios antenos dalis, bet ir pagal savo tiesioginę paskirti antenų gardelèse (angl. antenna array). Antenų gardelių sistemos naudojamos radaruose ir komunikacijų sistemose dèl jų ultra plačiajuostiškumo (angl. ultra wideband - UWB), kryptingumo diagramos reguliavimo elektroniniu būdu, didelio signalo triukšmo santykio. Tokiose sistemose svarbus plačiajuosčio LI, veikiančio nuo 15 iki $40 \mathrm{GHz}$ dažnių ruože, igyvendinimas. LI bandyta igyvendinti naudojant optines (Tur 2009), mikroelektromechanines (Kim et al. 2001) priemones, kurios leido pasiekti tinkamą vèlinimą, tačiau yra didelių matmenų ir reikalauja papildomų apdorojimo procesų. Panaudojat metalo oksido 
puslaidininkius (angl. complementary metal oxide semiconductor - CMOS) su meandrine struktūra sumažinami LI gabaritai ir gaunamas norimas vèlinimo laikas (Sanggu, Sanggeun 2013).

Kitą planarinių meandrinių įtaisų grupę sudaro filtrai, kurie taikomi ultra plačiajuosčiuose arba kelių veikimo dažnių komunikacijos įrenginiuose. Nuo XXI a. kilo susidomejjimas ịvairių juostinių ir užtvarinių filtrų kūrimu ir jų konstrukcijų matmenų mažinimu. Norint sukurti mikrobangų filtrą reikia atsižvelgti ị daugybę parametrų: centrinị pralaidumo juostos dažnị, pralaidumo juostos plotị ir pralaidumo juostas, esančias keliuose skirtinguose dažnių ruožuose. Dviejų pralaidumo juostų filtrai igyvendinami skirtingomis konstrukcijomis: taikant vienodos pilnutinés varžos rezonatorius, žiedinius pilnutinès varžos rezonatorius, meandrinius kilpinius rezonatorius, asimetrinius rezonatorius, daugiasluoksnines susietąsias struktūras, daugialaidès mikrojuostelines linijas (Marimuthu et al. 2013) ir kt. Darbe (Maleki, Dousti 2012) pristatomas kompaktiškas dviejų juostų juostinis filtras, sukurtas panaudojant meandrinius kilpos rezonatorius. Šis filtras dirba dviejuose 1,8 ir $2,4 \mathrm{GHz}$ dažnių ruožuose, turi gerą selektyvumą, $30 \%$ procentų mažesni dydį nei kiti dviejų juostų filtrai. Meandriniai laidininkai taip pat naudojami projektuojant filtrus su plačia užtvarine dažnių juosta. (Ghazali, Pal 2012) darbe aptariamas filtras, kuris pasižymi plačia slopinimo juosta iki $18 \mathrm{GHz}$ ir praleidžiantis tik 5,725-5,825 GHz dažnių ruožą. Parodoma, kaip nuo meandrinių laidininkų skaičiaus bei konfigūracijos (laidininko pločio, tarpo tarp laidininkų ir atstumo tarp meandrų) priklauso praleidžiamų dažnių ruožas ir skaičius - galima sudaryti vieno, dviejų ir trijų praleidžiamųjų ruožų filtrą.

Šiuo metu dèl didesnio kiekio naudojamų belaidžių duomenų perdavimo irenginių, atsiranda poreikis stebèti aplinkos elektromagnetinių bangų spektrą realiuoju laiku. Tai daroma naudojant realaus laiko skaitmeninius arba analoginius signalo apdorojimo būdus. Žemuose dažniuose patrauklesni skaitmeniniai ìtaisai dèl jų mažo dydžio, žemos kainos, patikimumo. Tačiau aukštuose dažniuose (milimetrų eilès, pvz., $60 \mathrm{GHz}$ ) nukenčia skaitmeninių itaisų veikimo efektyvumas, dideja skaitmeninių analoginių (ir atvirkščiai) keitiklių kaina bei suvartojamos energijos kiekis. Kaip alternatyva tokiuose aukštuose dažniuose galima taikyti analoginius ịtaisus ir sistemas signalų realiuoju laiku apdorojimui. Tokie įtaisai ir sistemos veikia realiuoju laiku, nereikalauja papildomų duomenų buferių, palyginus nebrangūs ir sunaudoja mažiau energijos. Pagrindinis šių analoginių ịtaisų elementas yra dispersinis LI, pvz., meandrinè vẻlinimo linija. Plačiajuostis signalas sklisdamas šiose linijose išplečiamas laike, kadangi skirtingos signalo spektro komponentès keliauja skirtingu greičiu. Pasinaudojant šia savybe plačiajuostis signalas gali būti apdorotas realiuoju laiku (Qingfeng et al. 2013). LI dispersines savybès galima pritaikyti realaus laiko Furjè ir atvirkštinei Furjè transformacijai (Gupta, Caloz 2010), loginèse periodinèse antenose dispersijai 
kompensuoti (Gupta, Caloz 2011), realaus laiko spektro analizatoriuose (Nikfal et al. 2011).

Planarinès meandro formos linijos taip pat naudojamos projektuojant fazès keitiklius ir signalų šakotuvus, taikomus komunikacijų sistemose ar monolitiniuose mikrobangu integriniuose grandynuose. Darbe (Taufiqqurrachman 2012) pristatomas Wilkinson šakotuvas (1.3 pav.) veikiantis $456 \mathrm{MHz}$ dažnyje. Ši šakotuvą sudaro dvi meandrinès linijos, suderinančios iejjimą ir išejimus. Pasiūlytos konfigūracijos šakotuvo dydis mažesnis ir efektyvesnis nei tradicinès struktūros Wilkinson šakotuvų, sudarytų iš paskirstytų parametrų elementų.

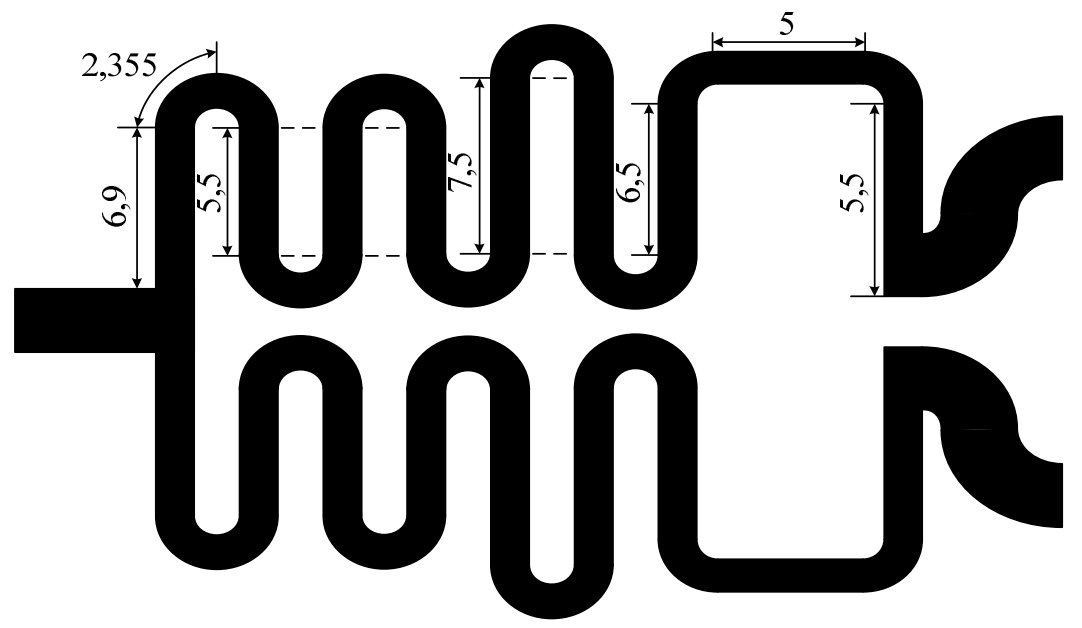

1.3 pav. Wilkinson galios daliklio eskizas, matmenys nurodyti milimetrais (Taufiqqurrachman 2012)

Fig. 1.3 Layout with dimensions in millimeters of Wilkinson power divider (Taufiqqurrachman 2012)

Apibendrinant galima teigti, kad šiuo metu yra labai daug lètinimo įtaisu ar jų pagrindų veikiančių sistemų taikymo sričių. Kuriant naujas elektronines sistemas tenka tobulinti LI ar jų struktūrų modelius, kadangi naudojami ir kuriami vis aukštesnio dažnio komunikacijų prietaisai.

\subsubsection{Lètinimo ịtaisų pagrindiniai parametrai ir jų skaičiavimas}

Lètinimo ịtaisų konstrukciniai matmenys didesni už juose sklindančias elektromagnetines bangas, todèl šių linijų projektavimui bei analizei panaudojamos grandinių ir ilgujų linijų teorijos. Ilgoji linija vadinama elektrine grandine, sudaryta iš dviejų ar daugiau laidininkų, atskirtų dielektriku, kai laidininkų ilgis yra vienos eilès arba didesnis už perduodamų virpesių bangos ilgị, o skerspjūvio 
matmenys yra daug mažesni už šios bangos ilgi (Vainoris 2004). Ilgosios linijos apibūdinamos pirminiais ilgosios linijos parametrais (ekvivalentinè schema pateikta $1.4 \mathrm{pav}$.): ilginiu induktyvumu $L_{1}$ (apibūdina linijos induktyvumą ilgio vienetui $(\mathrm{H} / \mathrm{m})$ ), ilgine talpa $C_{1}$ (apibūdina linijos talpą ilgio vienetui $(\mathrm{F} / \mathrm{m})$ ), aktyviaja varža $R_{1}$ (apibūdina nuostolius linijos laidininke $(\Omega / \mathrm{m})$ ) ir aktyviuoju laidžiu $Y_{1}$ (apibūdina linijos dielektriko laidumą $(\mathrm{S} / \mathrm{m})$ ).

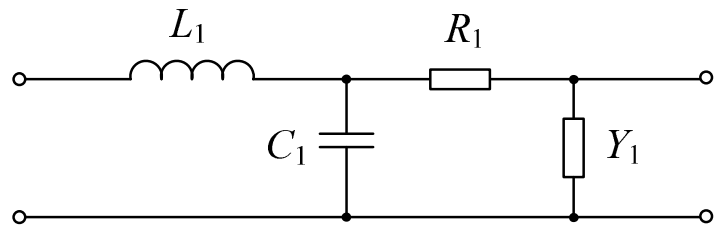

1.4 pav. Ilgosios perdavimo linijos ekvivalentinè schema

Fig. 1.4 Transmission line equivalent circuit

Pirminiai ilgosios linijos parametrai priklauso tiktai nuo linijos skerspjūvio matmenų ir laidininkus skiriančių dielektrikų elektrinių ir magnetinių savybių. Dèl skirtingos pirminių parametru priklausomybės perdavimo linijas galima suskirstyti į: vienalytes arba nevienalytes, pastovių arba kintamų parametrų, tiesines arba netiesines ir idealias arba su nuostoliais.

Ilgosios linijos, kartu su prijungtu elektrovaros šaltiniu bei apkrova, tikslias matematines išraiškas, aprašančias procesus tokioje sistemoje, galima gauti tik taikant Maksvelo (angl. Maxwell) lygtis. Sudaromos išraiškos būtų sudètingos ir ilgosios linijos parametrus būtų galima apskaičiuoti tik taikant skaitinius metodus. Kitas būdas aprašyti ilgojoje linijoje vykstančius procesus - taikant grandinių teorija arba analitinius metodus. Remiantis grandinių teorija, galima gauti tik apytikres formules, ivertinančias skersinių elektromagnetinių bangų (angl. transverse electromagnetic - TEM) sklidimą ilgojoje linijoje (Vainoris 2004). Lètinimo ịtaisai, kaip ir ilgosios linijos, gali būti apibūdinamos dažninèmis ir laiko charakteristikomis: elektromagnetinès bangos sklidimo faziniu greičiu, būdingają varža ir iejjimo varža. Bangos sklidimo fazinis greitis TEM artinio atveju apibūdinamas:

$$
v_{\mathrm{f}}=\frac{1}{\sqrt{L_{1} C_{1}}} .
$$

Ilgosiose linijose su nevienalyčiais dielektrikais (pvz., mikrojuostelinės linijos) bangos fazinis sklidimo greitis $v_{\mathrm{f}}$ priklauso nuo linijos konstrukcinių parametrų. Linijos būdingoji varža TEM artinio atveju apibūdinama: 


$$
Z_{\text {в }}=\sqrt{\frac{L_{1}}{C_{1}}} .
$$

Būdingoji varža $Z_{\mathrm{B}}$ nusako santykị tarp įtampos ir srovès ilgojoje linijoje ir, bendruoju atveju, yra dydis priklausantis nuo linijos laidininko parametrų ir dielektriko, supančio laidininkus, elektrinių ir magnetinių savybių. Dažninè būdingosios varžos priklausomybė apskaičiuojama iš įtampos ir srovès santykio tam tikrame linijos taške:

$$
Z_{\text {В }}(z, \omega)=\frac{U(z, \omega)}{I(z, \omega)},
$$

čia $U(z, \omega)$ ir $I(z, \omega)$ krintančios bangos įtampos ir srovès priklausomybè nuo dažnio tam tikrame taške $z$. Signalai lètinimo itaisais sklinda baigtiniu greičiu, t. y. sklinda tam tikro ilgio elektromagnetinè banga. Todèl įtampos ir srovès vertès yra skirtingos skirtinguose LI taškuose. Priklausomai nuo taško, kuriame skaičiuojama dažninè būdingosios varžos charakteristika, šis dydis gali būti skirtingai interpretuojamas: jei pasirenkamas iejjimo taškas $(z=0)$, tai šiame taške apskaičiuotą dydị galima interpretuoti kaip įjjimo varža.

Priklausomai nuo nagrinejamo ịtaiso paskirties greta aptartų charakteristikų naudojamos ir kitos charakteristikos. Tarkime, meandrinių mikrojuosteliniu vèlinimo linijų (MMVL) svarbiausios charakteristikos: vèlinimo trukmès dažninè charakteristika, dažninė amplitudès charakteristika, dažninė fazės charakteristika. Kompleksinè dažninè charakteristika apskaičiuojama pagal tokią išraišką:

$$
K(\mathrm{j} \omega)=\frac{\underline{U}_{\mathrm{I} \check{\mathrm{S}}}}{\underline{U}_{\mathrm{II}}}=K(\omega) \mathrm{e}^{\mathrm{j} \varphi(\omega)},
$$

čia $\underline{U}_{I \check{s}}$ ir $\underline{U}_{\underline{I} \text { Ė }}$ itampos kompleksinès amplitudès MMVL išèjime ir ièjime; $K(\omega)$ - dažninė amplitudès charakteristika; $\varphi(\omega)$ - dažninè fazès charakteristika; $\omega$ - kampinis dažnis.

Vèlinimo trukmès dažninè charakteristika apskaičiuojama taip:

$$
t_{\mathrm{v}}(\omega)=\frac{\varphi(\omega)}{\omega}, t_{\mathrm{v}}(\omega)=\frac{l}{v_{\mathrm{f}}(\omega)},
$$

čia $l$ - vèlinimo linijos ilgis.

LI laikinèms charakteristikoms gauti naudojama impulsinė $h(t)$ arba pereinamoji $g(t)$ charakteristikos. Šios charakteristikos vaizdžiai parodo perduodamų per LI impulsų formos iškraipymus, tačiau iš šių charakteristikų nematyti 
kodèl įvyko iškraipymai. Iškraipymų priežasties nustatymui naudojamos dažninès LI charakteristikos ir kurių sąryšis su laikinėmis charakteristikomis yra toks:

$$
\begin{gathered}
h(t)=\frac{K(0)}{2}+\frac{1}{\pi} \int \frac{K(\omega)}{\omega} \cdot \sin (\omega t+\varphi(\omega)) \mathrm{d} \omega, \\
g(t)=\frac{1}{2 \pi} \int K(\mathrm{j} \omega) \mathrm{e}^{\mathrm{j} \omega t} \mathrm{~d} \omega .
\end{gathered}
$$

Vèlinimo signalo formos iškraipymai LI turi būti leistino dydžio. Signalo iškraipymus lemia amplitudžių ir fazès dažninès charakteristikos. Vèlinimo linijose lemiamas vaidmuo tenka faziniams iškraipymams, šių iškraipymų nèra nedispersinèse vèlinimo linijose, t. y. linijose, kuriose elektromagnetinès bangos greitis nepriklauso nuo dažnio (tokių linijų fiziškai pagaminti neįmanoma). Faziniai iškraipymai LI leistini, jeigu vélinimo laiko pokytis aukščiausiam signalo spektro dažniui mažesnis už $\Delta t_{v}=0,5 / \omega$. Amplitudiniai iškraipymai leistini, jeigu signalo spektro ribose dažninès amplitudès charakteristikos netolygumai ne didesni nei $-3 \mathrm{~dB}$.

\subsection{Lètinimo ịtaisų analizès metodai}

Mikrobangų lètinimo ịtaisus sudaro komponentai, kurių matmenys yra tokios pačios ar mažesnès eilès, kaip ir juose sklindančios elektromagnetinès bangos ilgis. Todèl mikrobangų ịtaisų elektrinès charakteristikos smarkiai priklauso nuo jų struktūros matmenų ir konstrukcijos, taip pat ir nuo įtaisą supančios terpès charakteristikų. Šių ịtaisų pirminiai elektriniai parametrai apskaičiuojami iš Maksvelo lygčių, aprašančių elektrinius ir magnetinius laukus. LI gali būti labai sudètingi, o jų matematinis modelis turèti daugeli kintamujjų, aprašančiu ịtaiso struktūrą, tuo tarpu elektrinių parametrų, apibūdinančių ịtaiso veikimą, paprastai būna žymiai mažiau (Swanson, Hoefer 2003).

Žinant tam tikro LI konstrukcijos parametrus, galima gauti ịtaiso elektrinius parametrus atliekant ịtaiso analizę (ar modeliavimą) plačiame dažnių diapazone. Modeliuojamo LI analizès rezultatas turètų būti vienodas bei tenkinti paklaidos ribas nepriklausomai nuo pasirinkto modeliavimo metodo. Pasitelkiant ekvivalentiniu grandinių ir ilgụų linijų teorijas LI modeliavimui, sukurti labai efektyvūs analizès ịrankiai. Tačiau, naudojant šiuos metodus neatsižvelgiama ị visus nagrinejjamo įtaiso konstrukcinius parametrus. Siekiant ịvertinti visus įtaiso modelio kintamuosius - reikia naudoti metodus, kurie leistų įvertinti LI konstrukcinius parametrus ir jame sklindančias elektromagnetines bangas. Elektromagneti-

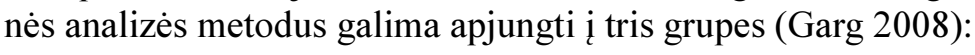


1. Analitiniai metodai. Šiuo atveju gaunami artimi sprendiniai (angl. closed form solution) išreikšti analitinèmis funkcijomis. Metodai supaprastina sprendžiamą uždavini, taip leidžia numatyti įrenginiuose vykstančius fizikinius procesus, tačiau nukenčia skaičiavimo tikslumas.

2. Skaitiniai metodai. Skaitiniai metodai transformuoja integralines ar diferencialines Maksvelo lygtis ị apytikres diskretines formas. Egzistuoja daugelis metodų, leidžiančių diskretiškai aprašyti nagrinèjamą elektromagnetinį uždavinị.

3. Hibridiniai metodai. Uždavinys sprendžiamas pasitelkus įvairių metodụ derini, pavyzdžiui neuronų tinklų arba neraiškiosios logikos naudojimas nagrinejjamo įtaiso parametrų nustatymui, panaudojant skaitiniais metodais sudarytą duomenų bazę.

Analitiniai metodai taikomi nesudètingos konstrukcijos įtaisų dvimačiams uždaviniams spręsti, nes matematiškai aprašyti komplikuotos konfigūracijos struktūras yra problematiška. Ši problema ịveikiama skaitiniais metodais, kuriais sprendžiami ịvairių dvimatès ir trimatès sandaros ịtaisų elektromagnetiniai uždaviniai. Skaitiniai metodai turi savų trūkumų - gaunami apytiksliai sprendiniai, dideli poreikiai kompiuterio ištekliams.

\subsubsection{Analitiniai lètinimo ịtaisų analizès metodai}

XX a. septintajame dešimtmetyje lètinimo įtaisų parametrams skaičiuoti buvo pritaikytas konforminių pakeitimų metodas, kurio pagrindu galima išvesti inžineriniams skaičiavimams patogias formules. Plačiausiai žinomi Vylerio (angl. Wheeler) (Wheeler 1964) ir Sneiderio (angl. Schneider) (Schneider 1972) pakeitimų būdai. Šneideris konforminiams pakeitimams naudojo elipsinius integralus, dèl šios priežasties jo išvestos išraiškos sudètingesnès nei Vylerio pateiktos.

Kitas analitinis metodas, plačiai naudojamas lètinimo sistemų analizei daugialaidžių linijų metodas, kuris nuodugniai aprašytas (Вайнорис et al. 1986; Weiss 1974) darbuose. Taikant daugialaidžių linijų metodą reikia žinoti ją modeliuojančios daugialaidès linijos būdingąsias varžas (arba būdinguosius laidumus) ir bangos sklidimo greiti. Bendruoju atveju pagal daugialaidžių linijų metodą laikoma, kad lygiagrečiai išdèstytų laidininkų skaičius yra begalinis modeliuojamas įtaisas yra periodinis (pavyzdys pateiktas 1.5 paveiksle). Daugialaidžių linijų metodas grịstas kvazi-TEM artiniu, t. y. daroma prielaida, kad nagrinèjamoje lètinimo sistemos skerspjūvio srityje egzistuoja tik skersinè elektromagnetine banga. Atsižvelgiant i kvazi-TEM artinị ir sklindančių bangų modas, galima užrašyti šios periodinès lètinimo sistemos įtampų ir srovès išraiškas (Kleiza, Štaras 2000): 


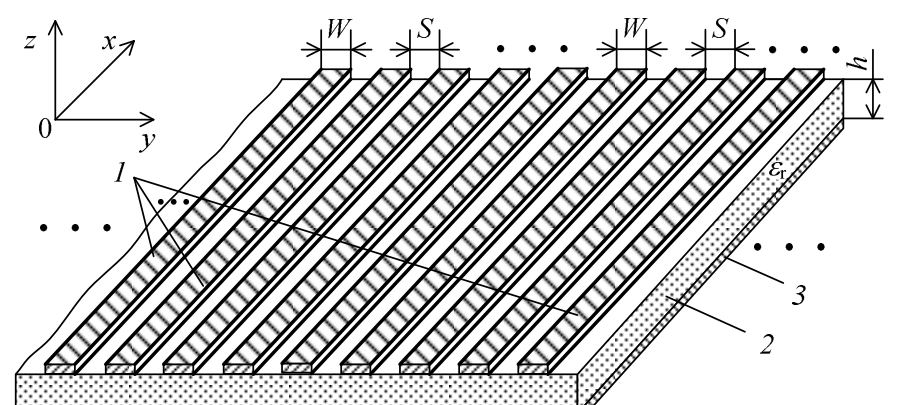

(a)

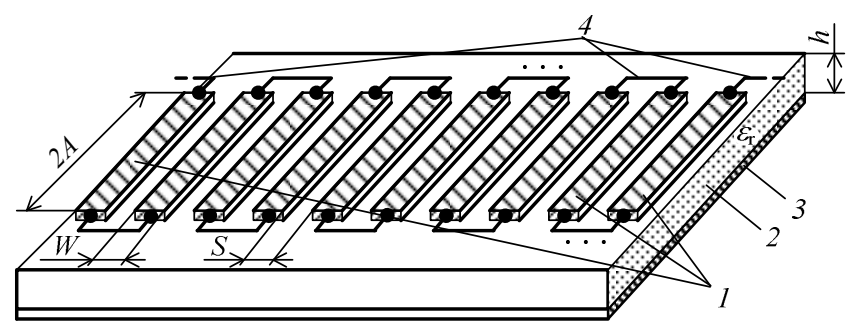

1.5 pav. Daugialaidès mikrojuostelinès linijos sandara (a) ir jos pagrindu sudarytos meandrinès mikrojuostelinès vẻlinimo linijos modelis (b); čia 1 - linijos laidininkai, 2 - dielektrinis pagrindas, 3 - ekranas, 4 - meandro strypu jungtys

Fig. 1.5. The generalized structure of the microstrip multiconductor line (a), and microstrip meander structure (b), where 1 - conductors of the line; 2 - a dielectric substrate; 3 - a reference conductor; 4 - connectors of the meander strips

$$
\begin{gathered}
\underline{U}_{n}=\sum_{i=0}^{N-1}\left(\underline{A}_{i} \sin k x+\underline{B}_{i} \cos k x\right) e^{-\mathrm{j} n \theta_{i}}, \\
\underline{I}_{n}=\mathrm{j} \sum_{i=0}^{N-1} Y\left(\theta_{i}\right)\left(\underline{A}_{i} \cos k x-\underline{B}_{i} \sin k x\right) e^{-\mathrm{j} n \theta_{i}},
\end{gathered}
$$

čia $N$ - daugialaidès linijos periode esančių laidininkų skaičius; $k$ - fazès koeficientas; $n$ - laidininko numeris linijoje; $\underline{A}_{i}, \underline{B}_{i}$ - amplitudžių koeficientai; $\theta_{i}-$ fazès kampas tarp îtampų ar srovių gretimuose linijos laidininkuose; $Y\left(\theta_{i}\right)-$ daugialaidès linijos būdingasis laidumas.

Lygčių (1.8) ir (1.9) amplitudžių koeficientų $\underline{A}_{i}$ ir $\underline{B}_{i}$ ryšys nustatomas užrašius laidininkų atkarpų galų srovių ir įtampų ribines sąlygas. Sudaroma nežinomų koeficientų $\underline{A}$ ir $\underline{B}$ lygčių sistema, iš kurios gaunama dispersinè lygtis, 
siejanti fazès kampą $\theta$ ir fazès koeficientą $k$. Taigi, lètinimo sistemų analizè daugialaidžių linijų metodu vykdoma keliais etapais (Kleiza, Štaras 2000):

1. Lètinimo sistemos modelio sudarymas iš daugialaidžių linijų atkarpų.

2. İtampos ir srovès lygčiu bei ribinių sąlygų daugialaidès linijos atkarpai užrašymas, dispersinių lygčių ir banginių varžų išraiškų gavimas.

3. Algoritmo lètinimo sistemos charakteristikoms skaičiuoti sudarymas.

Daugialaidžių linijų metodas plačiausiai taikytas meandrinių vèlinimo linijų (Burokas, Štaras 2008), ištęsto stačiakampio spiralinių lètinimo sistemų analizei (Štaras et al. 2010) ir kitų periodinių sistemų modeliavimui (Zyuryukin, Lyamin 2006). Daugialaidèmis linijomis modeliuotos LI lygiagrečių laidininkų atkarpos yra statmenos modeliuojamos sistemos ašiai, o skerspjūvio matmenys ir konstrukcija sutampa su nagrinèjama sistema. Daugialaidžių linijų metodas leidžia ivertinti laidininko konfigūraciją ir matmenis, tačiau dèl daromų prielaidų, jog laidininkų skaičius yra begalinis ir begalinio ilgio, neịvertinami mikrojuostelinės ar spiralinès linijos kraštų ir galų efektai. Skaičiuojant lètinimo koeficientą, reikia rasti modeliuojančios daugialaidès linijos būdinguosius laidžius ar būdingąsias varžas. Šiems parametrams apskaičiuoti taikytini dalinių talpų ir konforminių pakeitimų skaičiavimo analitiniai bei skaitiniai metodai (Śtaras et al. 2012).

\subsubsection{Skaitiniai lètinimo ịtaisu analizès metodai}

Visų skaitinių metodų taikymo tikslas - rasti kuo artimesnius Maksvelo lygčiu (ar lygčių išvestų iš jų) sprendinius, kurie tenkina nustatytas ribines ir pradines sąlygas. Sprendžiant elektromagnetinius uždavinius siekiama nurodyti savybes, kurias sprendinys turi tureti. Šios savybès apibūdinamos kaip lokaliosios (diferencialinès) arba globaliosios (integralinės) - tiek srities ribose, tiek prie srities ribų. Taigi, sprendžiamos diferencialinès arba integralinès lygtys, laikantis tam tikrų sąlygų (Swanson, Hoefer 2003).

Šio tipo sprendimu igyvendinimo kompiuteriuose pagrindas yra klasikine matematinè aproksimacija, kuomet nežinoma funkcija $f(x)$ aproksimuojama $n$ žinomų (bazinių) funkcijų $f_{n}(x)$ suma:

$$
f(x) \approx \sum_{n} \alpha_{n} \cdot f_{n}(x) .
$$

Kiekvienos bazinès funkcijos svoriai arba koeficientai $\alpha_{n}$ turi būti parinkti taip, kad bazinių funkcijų suma kuo arčiau priartètų prie ieškomos funkcijos. Pagrindiniai skirtumai tarp įvairių skaitinių metodų yra šie (Swanson, Hoefer 2003): 
a) aproksimuojamos elektromagnetinio uždavinio srities dydis (atvira arba uždara sritis);

b) bazinès funkcijos, kurios taikomos nežinomo sprendinio aproksimacijai;

c) bazinių funkcijų koeficientų nustatymo pasirinktas būdas.

Pasirinktos problemos sprendimui gali prireikti rasti elektrini ar magnetini lauką, potencialų, krūvių ir (arba) srovių pasiskirstymą. Išvardinti parametrai yra tarpusavyje susiję, tačiau jie turi skirtingas savybes ir skirtingus radimo būdus. Ieškant laukų stiprių ar potencialų verčių - reikalingos bazinès funkcijos erdvejje (diferencialiniai metodai), ieškant nežinomų krūvių ar srovių pasiskirstymo, išskaidomos i funkcijas, kurios aprašomos integralais (integraliniai metodai). Taip pat egzistuoja daugybe skirtingų būdų nežinomų koeficientų $\alpha_{n}$ apskaičiavimui: didelių matricų inversija, tiesioginè ir netiesioginès iteracijų schemos, evoliuciniai algoritmai ir t. t. (Bondeson et al. 2005). Dažniausiai naudojami skaitiniai metodai elektrodinaminiams uždaviniams spręsti yra šie:

- baigtinių skirtumų metodas - BSM (angl. finite difference methodFDM);

- baigtinių skirtumų laiko srities - BSLS (angl. finite difference time domain - FDTD);

- baigtinių elementų metodas - BEM (angl. finite element methodFEM);

- momentų metodas - MOM (angl. method of moments - MoM).

Pirmasis iš skaitinių metodų elektromagnetiniams uždaviniams spręsti buvo pritaikytas baigtinių skirtumų metodas. Šis metodas sukurtas XX a. trečiajame dešimtmetyje spręsti netiesinèms hidrodinamikos lygtims, tuomet buvo vadinamas kvadratų metodu (Thom, Apelt 1961). Nuo tụ laikų šis metodas plačiai taikomas įvairių sričių problemų sprendimams rasti. Baigtinių skirtumų metodas pagrịstas aproksimacija, t. y. dalinių išvestinių lygčių pakeitimas dalinių skirtumų lygtimis. Ši baigtinų skirtumų aproksimacija yra algebrinès formos ir ieškomo kintamojo vertè sprendimo srityje nustatoma iš greta esančių mazgų verčių. Sprendžiant uždavinius baigtinių skirtumų metodu, atliekami šie žingsniai:

1. Nagrinèjamo elektrodinaminio įtaiso sritis suskaidoma analizès tinkleliu.

2. Diferencialinė lygtis išreiškiama ekvivalentiška baigtinių skirtumų lygtimi, kurioje nagrinejjamo mazgo vertè priklauso nuo gretimų mazgų verčiu skirtumų.

3. Sudarytų skirtumų lygčiu sistema sprendžiama atsižvelgus ị tam tikras analizuojamos sistemos ribines ir (arba) pradines sąlygas.

Parinkus pradinius nagrinèjamo ịtaiso laidžiujų dalių potencialus, randamas potencialo pasiskirstymas nagrinejamoje srityje. Iš potencialo pasiskirstymo randami kiti analizuojamo ịtaiso parametrai. Skaičiavimo baigtinių skirtumų me- 
todu tikslumas didejja didinant tinklelio mazgų skaičių, tačiau dèl šios priežasties didejja duomenų masyvai ir skaičiavimo trukmè. Metodo pritaikymas elektromagnetinių uždavinių sprendimui išsamiai aptariamas (Sadiku 2009; Booton 1992) darbuose. Taikant ši metodą rastas elektrinio lauko pasiskirstymas mikrojuostelinio filtro skerspjūvyje (Huang, You 1998), šis metodas pritaikytas ir mikrojuostelinių bei juostelinių linijų skaičiavimams (Rosales, Suster 1995).

Laiko srities metodai plačiausiai taikomi ịvairių elektromagnetiniu problemu sprendimui (Bondeson et al. 2005). Vienas iš tokių metodų yra baigtinių skirtumu laiko srities metodas, kuris išsamiai aprašytas (Sadiku, Obiozor 2000) darbe. Modeliuojant mikrobangu ịtaisus baigtinių skirtumu laiko srities metodu, visa nagrinejjama sritis padalinama ị Yee gardeles (Yee 1966), kuriose išdèstomos elektrinių ir magnetinių laukų komponentès. Kiekviena elektrinio ir magnetinio lauko komponente apskaičiuojama aproksimuojant dalinių išvestinių Maksvelo lygtis centrinių skirtumų lygtimis. Šių laukų komponentès skaičiuojamos visoje nagrinejjamoje srityje, kiekviename analizuojamame laiko žingsnyje. Tam tikros lauko komponentès reikšmé priklauso nuo visų ją supančių komponenčių ir nuo buvusios šios komponentès reikšmių. Šiuo metodu nagrinejjant LI esančius atviroje erdvejje būtina sudaryti krintančiąsias elektromagnetines bangas sugeriančias ribines sąlygas, o tai padidina sudaromo modelio sudetingumą. Baigtinių skirtumų laiko srities metodu nagrinèjamos daugialaidès linijos (Feng et al. 2002) darbe, pritaikomas netolygiu perdavimo linijų analizei (Watanabe et al. 2009), taip pat analizuojami ịvairūs mikrobangu ịtaisai (Lingjiang et al. 2012; Mittal et al. 2012).

Harrington (Harrington 1993) pirmasis pavartojo momentų metodo pavadinimą sprendžiant elektromagnetinius uždavinius ir aprašè metodo ypatumus ir plètrą. Momentų metodas plačiai aprašytas (Gibson 2007) darbe, o atliekant elektrodinaminio įtaiso analizę šiuo metodu, reikia keturių etapų:

1. Tinkamos integralinès lygties išvedimas.

2. Integralinių lygčių konversija (diskretizacija) ị matricines lygtis, naudojantis pagrindinèmis (arba papildomomis) funkcijomis ir svorio (arba testinèmis) funkcijomis.

3. Matricos elementų įvertinimas.

4. Matricinių lygčių sprendimas ir ieškomų parametrų radimas.

Momentų metodas ir dalinių atvaizdų būdas pritaikytas įvairių mikrojuostelinių linijų analizei (Metlevskis, Urbanavičius 2011; Mikučionis, Urbanavičius 2011) darbuose. Momentų metodas sẻkmingai pritaikytas meandrinių vèlinimo linijų analizei ir projektavimui (Gurskas et al. 2010; Arash, Ramesh 2006), taip pat pritaikytas aukštos temperatūros superlaidžių daugialaidžių daugiasluoksnių linijų pilnosios bangos spektrinès srities analizei (Vendik et al. 2003). 
Baigtinių elementų metodas naudojamas kompleksinių netiesinių problemų elektrodinamikoje ir elektrostatikoje sprendimui. Šis metodas pagristas analizuojamos srities sudalinimu elementais (daugiakampiais) (Garg 2008). Daugiausia sudalinimui naudojami trikampiai, nes trikampiu tinkleliu galima lengviau aproksimuoti bet kokios formos paviršių, tačiau gali būt naudojami ir kiti daugiakampiai. Elementai (trikampiai) gali būti palyginus nedideli prie nagrinèjamų geometrinių detalių ir stambesni kitur. Nepriklausomai nuo elementų formos, laukas aproksimuojamas skirtingomis išraiškomis kiekviename elemente, tačiau vietose, kur elementai jungiasi (pvz.: trikampių kraštuose), laukas turi sutapti, kad būtų išlaikytas tęstinumas. Šiuo metodu nagrinëjamos meandrinių vèlinimo linijų charakteristikos (Topsakal, Volakis 2003), daugialaidès mikrojuostelinès linijos su nuostoliais (Bertazzi et al. 2003).

Apskaičiuotų verčių tikslumas ir algoritmo stabilumas yra labai svarbios sąvokos igyvendinant bet kuri skaitinį metodą, nes tuomet galima nusakyti ar gautas rezultatas yra patikimas ir taikytinas. Tikslumas apibūdina kiek skiriasi ieškomas sprendinys nuo tikrojo sprendinio. Stabilumas nusako ar naudojamas sprendimo būdas nepadidins bendros paklaidos skaičiavimus atliekant skirtingais laiko momentais. Skaitinis algoritmas yra stabilus, jei bendroji klaidu suma smarkiai nedideja bet kuriame sprendimo etape, kitu atveju jis yra nestabilus. Yra trys pagrindiniai klaidų tipai, kurių negalima išvengti sprendžiant fizikinius uždavinius skaitiniais metodais (Vemuri, Karplus 1981): modeliavimo klaidos; diskretizacijos klaidos; apvalinimo klaidos.

Nuo kiekvienos iš šių klaidų priklauso sprendimo tikslumas. Modeliavimo klaidos atsiranda dèl tam tikrų supaprastinamo prielaidų daromų matematiniame modelyje. Pavyzdžiui, netiesine sistema gali būti aprašyta tiesinèmis dalinèmis diferencialinèmis lygtimis.

Diskretizavimo klaidos atsiranda dèl to, kad skaitinèje analizèje galima naudoti tik baigtinius skaičius, o nagrinèjami procesai, uždaviniai aprašomi begalinėmis eilutemis. Pavyzdžiui, sudarant baigtinių skirtumų lygtis, kai kurie aukštesnès eilès Teiloro (angl. Taylor) eilutès dèmenys atmetami, dèl to atsiranda diskretizacijos paklaida. Diskretizacijos klaidos gali būti sumažinamos naudojant tankesni tinkleli arba naudojant didesnị kiekị dèmenų Teiloro eilutèje, sudarant aukštesnès eilès aproksimacijas. Tačiau, kai naudojamos aukštesnès eilès skirtumų lygtys nei nagrinèjamos dalinès diferencialinès lygtys, gali atsirasti nestabilumas, o dèl nestabilumo didèja skaičiavimų paklaida.

Apvalinimo klaidos atsiranda dèl to, kad kompiuteriai yra baigtinio tikslumo irenginiai (pvz.: registrai aritmetiniame procesoriaus įrenginyje yra baigtinio dydžio). Šios klaidos gali būti sumažinamos naudojant dvigubo tikslumo aritmetiką. Visiškai išvengti apvalinimo klaidų galima tiktai tuomet, kai visos operacijos aprašomos naudojant sveikujų skaičių aritmetiką, tačiau tai praktiškai ịgyvendinti neįmanoma. Baigtinių skirtumų metode tankinant tinkleli mažeja 
nukirtimo klaidos, tačiau apvalinimo klaidos atvirkščiai - didejja, dèl padidejusio skaičiaus aritmetinių operacijų.

Skaitiniais metodais gristi komerciniai specializuoti programų paketai, kurie leidžia modeliuoti įvairius mikrobangų įtaisus. Kiekvienas iš šių mikrobangų ịtaisu analizès programinių paketų turi turèti šiuos įrankius (Hoefer et al. 2003): įtaiso struktūros braižymo, medžiagų savybių bei kraštinių sąlygų parinkimo, tinklelio sudarymo, analizės uždavinio sprendimo, rezultatų pateikimas bei atvaizdavimo. Šiuo metu labiausiai paplitę elektromagnetinių uždavinių sprendimui skirti programinès įrangos paketai: EMSIM $^{\circledR}, \mathrm{COMSOL}^{\circledR}, \mathrm{CST}^{\circledR}$ Microwave Studio $^{\circledR}$, Sonnet ${ }^{\circledR}$, HFSS $^{\circledR}$, QWED $^{\circledR}$, MAFIA $^{\circledR}$, SPICE $^{\circledR}$. Programiniai paketai palengvina ir paspartina létinimo sistemų analizę, tačiau esminius analizès apribojimus lemia pakete igyvendintas skaitinis metodas. Nuo šio metodo priklauso ne tik tai, kokio sudètingumo mikrobangu įtaisą galima analizuoti, bet ir skaičiavimo trukmè bei tikslumas.

\subsection{Autoriaus indèlis ị problemos sprendimą}

Prie elektrodinaminių LI tyrimo ir jų taikymo elektroniniuose itaisuose problemų sprendimo daug prisidejo profesoriai S. Štaras, R. Kirvaitis, R. Martavičius, J. Skudutis, L. Nickelson, V. Urbanavičius, docentai A. Gurskas, A. Jurjevas, V. Daškevičius, R. Pamarnacki, A. Katkevičius ir kiti. Lietuvoje LI tyrimus pradèjo prof. Vainorio vadovaujama mokslininkų grupè, kuri sukūrẻ vieningą LI analizès teoriją, ištyre ir palygino daugelio LI charakteristikas ir savybes. S. Staras tyrè spiralinès ir meandrinès konstrukcijos lètinimo ir kreipimo sistemas. R. Kirvaitis nagrinejjo elektrodinaminių vèlinimo linijų savybes. R. Martavičius tyrè plačiajuostes planarines lètinimo sistemas. V. Urbanavičius tyré mikrojuostelines vèlinimo linijas skaitiniais metodais. J. Skudutis ir V. Daškevičius nagrinejjo spiralines ir meandrines lètinimo sistemas universaliaja programine ịrangą.

Disertacijos autorius sukūrè mikrojuostelinių perdavimo, susietujų, daugialaidžių ir meandrinių vẻlinimo linijų modelius, taikant baigtinių skirtumų laiko srities metodą ir ištyre šių linijų charakteristikas plačiame dažnių ruože. Autorius taip pat ištyre galinių ir kraštinių laidininkų netolygumų ịtaką meandrinių mikrojuostelinių vèlinimo linijų laiko ir dažnio charakteristikoms.

\subsection{Apibendrinimas. Uždavinių formulavimas}

Apžvelgus elektrodinaminius lètinimo įtaisus (LI), jų taikymo sritis ir analizès metodus galima teigti, kad:

1. Meandrinès konstrukcijos LI plačiai taikomi ịvairios paskirties mikrobangu įtaisuose: antenose, filtruose, vèlinimo linijose ir kt. 
2. Sprendžiami lètinimo ịtaisų aktualūs uždaviniai yra šie: konstrukcijų matmenų ir svorio mažinimas nesiaurinant praleidžiamujų dažnių juostos, t. y. nedidinant nuostolių ir fazės iškraipymų; periodinių netolygumų tyrimas ir modeliavimas; naujų medžiagų pritaikymo galimybių tyrimas.

3. Plačiausiai LI tyrimui taikomi analitiniai, skaitiniai ir hibridiniai metodai. Analitiniai metodai skirti nagrinèti paprastesnių konstrukcijų LI, kuomet neatsižvelgiama i visus matematinio modelio kintamuosius. Skaitiniais metodais galima nagrinèti sudètingų konstrukcijų LI, tačiau efektyvus skaitinių metodų taikymas reikalauja didelès apimties skaičiavimo išteklių. Hibridiniuose metoduose derinami skaitiniai ir analitiniai metodai siekiant gauti tikslesnius LI modelius, kurie nereikalautu igyvendinimui išteklių, viršijančių įprastų darbo stočių galimybių.

4. Taupant skaičiavimo išteklius LI modeliavimui plačiai naudojamas daugialaidžių linijų metodas, tačiau pagal jị modeliuojamas ịtaisas yra begalinis ir tokiu būdu neịvertinamas ịtaiso galinių ir kraštinių laidininkų parametrų nevienalytiškumas.

5. Programinès įrangos, skirtos modeliuoti mikrobangu įtaisus, esminius apribojimus lemia pasirinktas skaitinis metodas. Nuo jo priklauso ne tik tai, kokio sudètingumo LI galima nagrinèti, bet ir skaičiavimo trukmè bei tikslumas.

6. LI modeliavimas naudingas siekiant suprasti įtaisuose vykstančius fizikinius procesus, o tai leidžia tobulinti esamas įtaisų konstrukcijas bei kurti naujas.

Tikslinga tirti meandrinių lètinimo sistemų savybes ir analizès metodus, siekiant patobulinti šias lètinimo sistemas ir jų automatizuoto projektavimo metodika. Šiam tikslui pasiekti reikia išspręsti šiuos uždavinius:

1. Sudaryti modelius ir ištirti pavienès, susietujų ir daugialaidžių mikrojuostelinių linijų laiko ir dažnines charakteristikas, taikant baigtinių skirtumų bei baigtinių skirtumų laiko srities analizès metodus.

2. Sudaryti tolygios būdingosios varžos daugialaidžių mikrojuostelinių linijų sintezès ir meandrinių mikrojuostelinių vèlinimo linijų analizès algoritmus bei jų laiko ir dažninių charakteristikų skaičiavimo metodikas.

3. Imitacinių skaičiavimų būdu patikrinti siūlomų LI parametrų skaičiavimo metodų veiksmingumą ir efektyvumą. 



\section{2}

\section{Mikrojuostelinès perdavimo linijos modelių sudarymas ir tyrimas}

Elektromagnetinès bangos savybė sklisti dielektrineje terpeje, kurios santykinè skvarba didesnè už vienetą, lèčiau negu vakuume, plačiai naudojama lètinimo įtaisuose. Mikrojuostelinių įtaisų, kurių sandarą sudaro plokščias dielektrikas ir laidžiosios mikrojuostelès, gamybos technologija labai efektyvi. Mikrojuostelinè linija yra pagrindinis elementas daugelio planarinių lètinimo sistemų, pvz.: plokščiųjų spiralinių, meandrinių, kai tarpai tarp meandro strypų yra labai dideli, ir pan.

Šiame skyriuje tiriami mikrojuostelinès linijos modeliai, sudaryti dviem skirtingais skaitiniais metodais, siekiant parinkti metodus linijos konstrukcinių parametrų sintezei ir dažninių bei laiko charakteristikų analizei, o taip pat palyginti taikomų metodų tikslumą. Skaičiuojami mikrojuostelinès linijos elektriniai parametrai baigtinių skirtumų ir baigtiniu skirtumų laiko srities metodais, gauti rezultatai lyginami su kitų autorių gautais rezultatais.

Skyriaus tematika paskelbti du autoriaus straipsniai (Krukonis 2010; Krukonis, Urbanavičius 2011). 


\subsection{Mikrojuostelinès perdavimo linijos modelis, grịstas baigtinių skirtumų metodu}

Šiame poskyryje nagrinèjama baigtinių skirtumų metodo ir susietujų matricų būdo taikymo galimybè mikrojuostelinès perdavimo linijos (MPL) analizei. Mikrojuostelinès perdavimo linijos dažnai naudojamos siųstuvo ir antenos suderinimui, o šiam tikslui pasiekti - skaičiuojama linijos būdingoji varža. MPL taip pat plačiai naudojamos filtruose, šakotuvuose ir kituose itaisuose, gristuose tam tikru sklindančio signalo fazès kitimu. Šiuo atveju turi būti įvertinta MPL efektyvioji dielektrinè skvarba. MPL taip pat yra neatsiejamas daugelio planarinių lètinimo sistemų elementas, pvz.: plokščiųu, spiralinių, meandrinių ir pan.

\subsubsection{Elektrinių parametrų apskaičiavimo algoritmas}

Mikrojuostelinès linijos elektrinių parametrų - būdingosios varžos ir efektyviosios dielektrinès skvarbos paieška pagal baigtinių skirtumų (BS) metodą tai dvimatis elektrodinaminis uždavinys (sprendimo srities suskaidymo tinkleliu pavyzdys pateiktas 2.1 paveiksle). Dvimatèje srityje šiam uždaviniui spręsti BS metodu panaudojamos Puasono (angl. Poisson) elipsinių dalinių išvestinų lygtys dviejų koordinačių sistemoje (Sadiku 2000):

$$
\nabla^{2} \varphi=\frac{\partial^{2} \varphi}{\partial x^{2}}+\frac{\partial^{2} \varphi}{\partial y^{2}}=g(x, y),
$$

čia $\nabla^{2}$ - Laplaso (angl. Laplace) operatorius; $x, y$-koordinatès; $\varphi$-elektrinio lauko potencialas; $g(x, y)$ - elektrinio lauko sužadinimo šaltinis. Sprendžiant (2.1) lygti BS metodu dalinèms išvestinèms rasti, naudojama centrinių skirtumų aproksimacija. Kai nagrinejjama sritis padalinama kvadratinių lastelių tinkleliu $\Delta x=\Delta y=\Delta$ ir srityje nèra sužadinimo šaltinio, (2.1) lygti galima išreikšti Laplaso lygties forma:

$$
\varphi(i, j)=\frac{1}{4}[\varphi(i+1, j)+\varphi(i-1, j)+\varphi(i, j+1)+\varphi(i, j-1)],
$$

čia $i, j$ - indeksai nurodantys ieškomo potencialo poziciją dvimatėje srityje. Iš (2.2) išraiškos matyti, kad analizuojamos srities tinklelio kiekvieno mazgo potencialo dydis yra lygus ji supančių keturių mazgų potencialų vidurkiui. Pažymètina, kad tai nevienintelis būdas aproksimuoti Laplaso lygtị, gali būti naudojami ir stačiakampio, nuožulnaus trikampio aproksimavimo būdai, tačiau centrinių skirtumų aproksimacija paprasčiau igyvendinama programiniu kodu, neprarandant tikslumo (Sadiku 2009). 


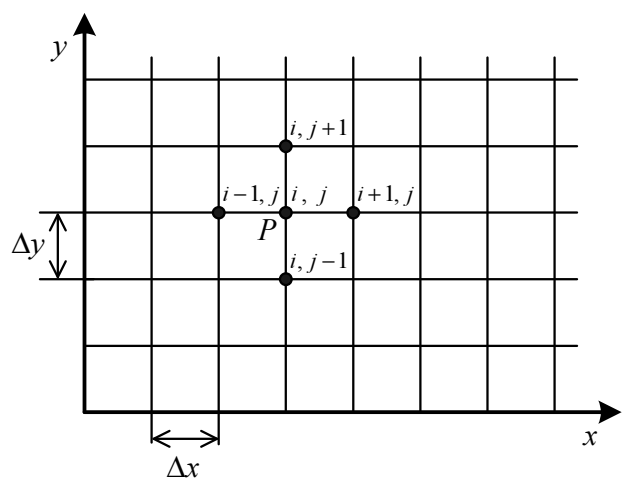

2.1 pav. Dvimatès analizuojamos srities tinklelis

Fig. 2.1. Grid of two-dimensional analysis field

Dalinių išvestinių lygčių sprendimas BS metodu veda prie didelių algebrinių lygčių sistemų sudarymo ir jų sprendimas yra didelè problema. Du pagrindiniai būdai naudojami tokių lygčių sistemų sprendimui:

- iteracinis;

- susietujų matricų.

BS sprendinio paieškos trukmè, taikant iteracinị skaičiavimo būdą, priklauso nuo siekiamo sprendimo tikslumo ir gali būti labai didelè. Skaičiavimams paspartinti taikytinas tiesioginis susietujų matricų būdas, pagal kuri baigtinių skirtumų sprendinys surandamas sudarius ir išsprendus tiesinių lygčių sistemą.

Iteracinis BS sprendinio paieškos būdas yra gerai aprašytas (Štaras 2008) darbe, todèl toliau išsamiau aptariamas tiesioginis susietųų matricų būdas. Pagal (2.2) tinklelio kiekvieno mazgo reikšmę veikia kiti artimiausi tinklelio mazgai, o tolimesni mazgai ịtakos neturi. Taigi analizuojamos srities tinklelio visų mazgų reikšmes galima rasti išsprendus lygti:

$$
[A] \times[X]=[B],
$$

čia $[A]$ - retoji matrica (angl. sparse matrix), turinti daugybę nulinių elementų; $[X]$ - vektorius, kuri sudaro nežinomos mazgų vertės; $[B]$ - vektorius, kurị sudaro žinomos mazgų vertès. Nežinomujjų vektoriaus $[X]$ reikšmès randamos naudojant, pvz., tokią išraišką:

$$
[X]=[A]^{-1} \times[B],
$$


čia $[A]^{-1}$ - atvirkštinè koeficientų matrica. Nežinomujų matricą taip pat galima rasti taikant mažiausių kvadratų metodą, ịvairius eliminavimo metodus (Gauso, Gauso Jordano ir kt.) (Davis 2006).

Išsprendus sudarytą tiesinių lygčių sistemą (2.3), gaunamas nežinomujų potencialų vektorius, kuris perkomponuojamas i potencialų pasiskirstymo matricą, o žinant potencialų pasiskirstymą galima rasti analizuojamo ịtaiso elektrinius parametrus: krūvio tankį, ilginę talpą ir pan.

Kuomet MPL sklindančios elektromagnetinès bangos ilgis yra mažesnis už dielektrinio pagrindo storị (praktiškai virpesių dažnis gali siekti dešimtis gigahercu), analizuojant liniją taikytinas kvazi-TEM artinys. Šiuo atveju MPL būdingoji varža $Z_{\mathrm{B}}$ ir santykinè efektiné dielektrinè skvarba $\varepsilon_{\mathrm{r} \text { ef }}$ gali būti apskaičiuotos žinant linijos ilgines talpas (Boutboul et al. 1998):

$$
\begin{gathered}
Z_{\mathrm{B}}=\frac{1}{c_{0} \sqrt{C_{1} C_{10}}}, \\
\varepsilon_{\mathrm{ref}}=\frac{C_{1}}{C_{10}},
\end{gathered}
$$

čia $c_{0}-$ šviesos greitis vakuume; $C_{1}-$ ilginè talpa; $C_{10}-$ MPL ilginè talpa, kai linijos dielektrinis pagrindas tariamai pakeičiamas oru.

Iš (2.5) ir (2.6) matyti, kad ieškant MPL elektrinių parametrų yra tik du nežinomieji - MPL ilginès talpos su vienalyčiu $C_{10}$ ir nevienalyčiu $C_{1}$ dielektriku. Ilginè talpa gali būti apskaičiuota taikant Gauso (angl. Gauss) dèsnị elektrinès indukcijos srautui arba sukauptos elektrinio lauko energijos sąvoką.

Taikant Gauso dèsni elektrinès indukcijos srautui, MPL supantis ilginis krūvis pagal BS metodą apskaičiuojamas sumuojant išilgai uždaro kontūro $L$, gaubiančio mikrojuostelę:

$$
q_{1}=-\sum_{L} \varepsilon \frac{\Delta \varphi}{2},
$$

čia $\Delta \varphi$ - potencialų skirtumas tarp dviejų artimiausių tinklelio mazgų vienas iš kurių yra kontūro viduje, o kitas - išorejje. Apejjimo kontūras $L$ parenkamas aplink mikrojuostelinę liniją (2.2 pav.). Siekiant sumažinti diskretizacijos paklaidą, kontūro atstumas nuo mikrojuostelinès linijos signalinio laidininko parenkamas kuo didesnis. Apskaičiavus visos mikrojuostelinès linijos potencialų pasiskirstymą tiek su vienalyčiu dielektriku (oru), tiek su nevienalyčiu dielektriku (oro ir dielektrinio pagrindo derinys), galima rasti MPL krūvị ilgio vienetui $q_{1}$. Žinant krūvị $q_{1}$, sutelktą MPL ilgio vienetui, bei signalinio laidininko potencialą $\varphi$, ilginè talpa apskaičiuojama taip: 


$$
C_{1}=\frac{q_{1}}{\varphi} .
$$

Taikant elektrinio lauko energijos sąvoką ilginès talpos apskaičiavimo formulè išvedama iš elektrinio lauko energijos, sukauptos tūryje išraiškos, ir užrašomos taip:

$$
C_{1}=\frac{2 W_{\mathrm{E}}}{\varphi^{2}},
$$

čia $W_{E}$ - elektrinio lauko energija nagrinejjamame tūryje. Potencialų skirtumą $\varphi$ prilyginus vienam voltui ir atsižvelgus ị tai, kad nagrinèjamas tūris MPL skerspjūvyje, (2.9) formulę galima išreikšti taip:

$$
C_{1}=\int_{A} \varepsilon|E|^{2} d A,
$$

čia $A$ - integravimo sritis. Iš šios lygties matyti, kad apskaičiuojant ilginę talpą būtina rasti elektrinio lauko stiprumo modulio kvadratą visoje pjūvio srityje. Pagal BS metodą kiekvieno srities tinklelio mazgo elektrinio lauko stiprio modulio kvadratas priklauso nuo šalia esančių potencialų skirtumų kvadrato:

$$
|E(P)|^{2} \cong \frac{\left(\varphi_{A}-\varphi_{C}\right)^{2}+\left(\varphi_{B}-\varphi_{D}\right)^{2}}{2 \Delta^{2}},
$$

čia $\Delta$ - tarpas tarp artimiausių tinklelio mazgų; $\varphi_{A-D}$ - potencialai esantys šalia analizuojamo taško. Apskaičiavus kiekvieno mazgo elektrinio lauko stiprumo modulio kvadratą, galima rasti visą mikrojuostelinès linijos ilginę talpą. Tokiu būdu apskaičiuojamos signalinio laidininko, esančio vienalyčiame dielektrike (ore) ir nevienalyčiame dielektrike, talpos, kurios panaudojamos būdingosios varžos ir efektyviosios dielektrinės skvarbos verčių apskaičiavimui.

Sudarant pavienès mikrojuostelinès linijos modeli svarbu parinkti ir susieti modelio parametrus (kintamuosius) ir realios modeliuojamos linijos konstrukcinius parametrus. Pagal BS metodą MPL laidininkams: signaliniam ir ekranui suteikiami žinomi potencialai (ekranui, dažniausiai, nulinis potencialas), o visa MPL analizuojama sritis tariamai išdèstoma laidžiajame, stačiakampio formos, ižemintame ekrane (2.2 pav., signalinis MPL laidininkas šiuo atveju yra dviejų terpių riboje - dielektrinis pagrindas apačioje ir oras iš viršaus). Pavienę mikrojuostelinę liniją apibūdinama šiais konstrukciniais parametrais (2.2 pav.): $m$ - analizuojamos srities plotis; $n$ - analizuojamos srities aukštis; $h$ - atstumas nuo apatinio ekrano iki signalinio laidininko (dielektrinio pagrindo storis); $h_{1}-$ atstumas nuo signalinio laidininko iki viršutinio ekrano; $W$ - signalinio laidininko plotis; $g$-atstumas nuo signalinio laidininko iki šoninio ekrano. 


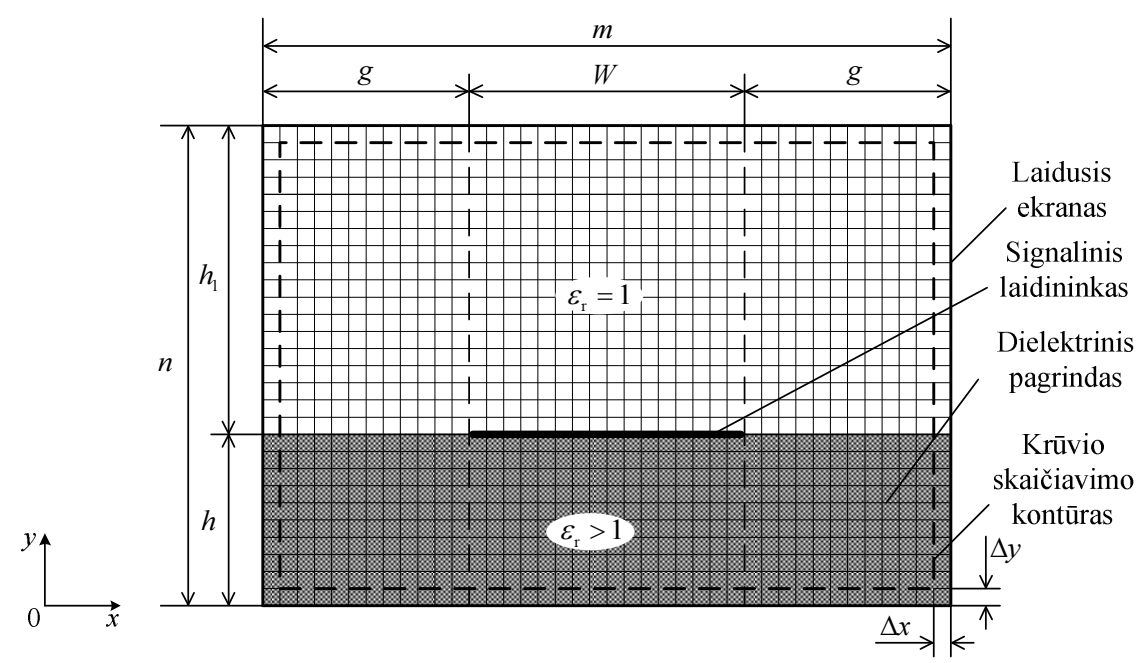

2.2 pav. Mikrojuostelinès linijos analizuojamos srities skerspjūvis padalintas tinkleliu

Fig. 2.2. Microstrip line cross section divided by mesh

Mikrojuostelinès linijos modelio, grịsto baigtinių skirtumų metodu, elektrinių parametrų apskaičiavimo algoritmas pateiktas 2.3 paveiksle. Algoritmą sudaro 10 žingsnių:

1. Ivedami analizuojamos MPL parametrai: $[m \times n]-$ analizuojamos srities dydis; $W$ - signalinio laidininko plotis; $\varphi_{\mathrm{sl}}$ - signaliniam laidininkui suteiktas potencialas; $\varepsilon_{\mathrm{r}}$ - dielektrinio pagrindo santykinė dielektrinè skvarba; $h$ - dielektrinio pagrindo storis. $[m \times n], W$ ir $h$ parametrai šiuo atveju matuojami tinklelio žingsniais $\Delta x$ arba $\Delta y$ $(\Delta x=\Delta y)$.

2. Atsižvelgiant i nurodytus konstrukcinius parametrus, sudaroma analizès sritis ir pradinè potencialų matrica $[\varphi]$, kurios viduryje oro ir dielektrinio pagrindo riboje suformuojama mikrojuostelinè linija.

3. Apskaičiuojamas nežinomų potencialų skaičius nagrinèjamoje srityje ir pagal (2.3) inicializuojama koeficientų matrica $[A]$ ir žinomų bei nežinomų potencialų $[X]$ ir $[B]$ vektoriai.

4. I atitinkamas pozicijas $[B]$ vektoriuje surašomos žinomų potencialų vertès. 
5. Apskaičiuojami ir $\mathfrak{i}$ atitinkamas pozicijas retojoje matricoje $[A]$ surašomi koeficientai. Atskirame vektoriuje išsaugojamos dielektrinio pagrindo ir oro terpių riboje esančių koeficientų pozicijos retojoje matricoje.

6. Taikant mažiausių kvadratų metodą sprendžiama tiesinių lygčių sistema ir gaunamas nežinomų potencialų $[X]$ vektorius. Iš $[X]$ vektoriaus potencialai surašomi atgal i atitinkamas pozicijas ieškomų potencialų $[\varphi]$ matricoje.

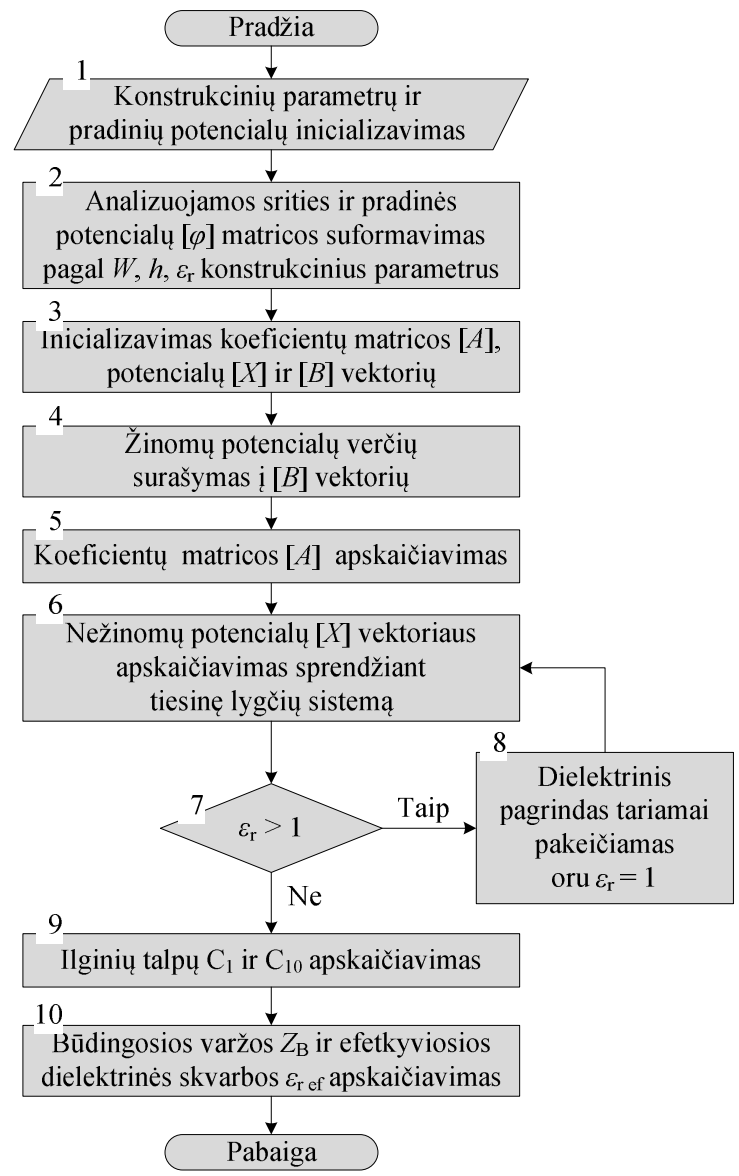

2.3 pav. Mikrojuostelinès linijos modelio, grịsto baigtinių skirtumų metodu, supaprastintas algoritmas

Fig. 2.3. The simplified algorithm of the microstrip line model based on finite difference method 
7. Patikrinama ar potencialų skaičiavimai atliekami esant nevienalytei analizuojamai sričiai (dielektrinis pagrindas ir oras virš jo) ar vienalytei sričiai (vietoje dielektrinio pagrindo - oras).

8. Koeficientų matricoje $[A]$ pakeičiamos terpių riboje esančių koeficientų vertès, kurios buvo išsaugotos 5 žingsnyje.

9. Sukuriamas ilginès talpos skaičiavimams reikalingas skaitmeninio integravimo kontūras ir apskaičiuojamos ilginès talpos tiek vienalytèje $C_{10}$ tiek nevienalytejje $C_{1}$ terpèje. Taikant elektrinio lauko energijos sąvoką ilginių talpų skaičiavimui, kiekvieno tinklelio mazgo energijos kvadratas randamas pagal (2.11) išraišką.

10. Pagal (2.5) ir (2.6) išraiškas atitinkamai apskaičiuojama būdingoji varža ir santykinè efektyvioji dielektrinè skvarba.

\subsubsection{Mikrojuostelinès linijos modelio tyrimas}

MPL modelio, grịsto BS metodu ir susietų matricų būdu, tyrimas buvo vykdomas dviem etapais: a) tikrinamas modelio adekvatumas, lyginant pagal ji gautus būdingosios varžos skaičiavimo rezultatus su kitų tyrèjų kitais metodais gautais rezultatais; b) nagrinejjamas modelio efektyvumas bei gautu skaičiavimo rezultatų priklausomybès nuo analizuojamos srities parametrų.

\section{Modelio adekvatumo patikra}

Mikrojuostelinès linijos elektrinių parametrų skaičiavimo rezultatams palyginti naudojami duomenys iš (Urbanavičius, Martavičius 2006; Cheng, Everard 1991) darbų. 2.1 lentelèje pateikti palyginamieji rezultatai gauti apskaičiuojant būdingają varžą atvirosios mikrojuostelinès linijos (t. y. iš šonų ir iš viršaus tokia linija neekranuota). Analizuojant 2.1 lentelèje pateiktus duomenis matyti, kad didžiausias santykinis skirtumas tarp būdingosios varžos skaičiavimo rezultatų, gautų taikant siūlomą modelị ir kitų tyrèjų kitais metodais gautų rezultatų neviršija 1,5\% (2.1 lentelè, eilutè $W / h=0,1)$. Tai rodo, kad siūlomas modelis leidžia pakankamai tiksliai analizuoti mikrojuostelinę liniją, esant ịvairiems linijos konstrukciniams parametrams.

\section{Modelio našumo ir tikslumo analizè}

MPL modelio elektriniai parametrai skaičiuojami iš ilginių talpų ((2.5) ir (2.6) išraiškos), kurios nustatomos iš BS metodu apskaičiuoto potencialo pasiskirstymo. Potencialo pasiskirstymo apskaičiavimo tikslumui turi įtakos MPL analizuojamos srities tinklelio tankumas ir, jeigu potencialai ieškomi iteraciniu būdu - skaičiavimo paklaida. 
2.1 lentelè. Trimis skirtingais metodais apskaičiuotos būdingosios varžos vertès

Table 2.1. Characteristic impedance values, calculated with three different methods

\begin{tabular}{|c|c|c|c|c|c|c|c|c|c|c|c|c|}
\hline \multirow{2}{*}{$W / h$} & \multicolumn{3}{|c|}{$\varepsilon_{\mathrm{r}}=6,0$} & \multicolumn{3}{c|}{$\varepsilon_{\mathrm{r}}=9,6$} & \multicolumn{3}{c|}{$\varepsilon_{\mathrm{r}}=13$} & \multicolumn{3}{c|}{$\varepsilon_{\mathrm{r}}=28$} \\
\cline { 2 - 14 } & $Z_{\mathrm{B}}, \Omega^{1}$ & $Z_{\mathrm{B}}, \Omega^{2}$ & $Z_{\mathrm{B}}, \Omega^{3}$ & $Z_{\mathrm{B}}, \Omega^{1}$ & $Z_{\mathrm{B}}, \Omega^{2}$ & $Z_{\mathrm{B}}, \Omega^{3}$ & $Z_{\mathrm{B}}, \Omega^{1}$ & $Z_{\mathrm{B}}, \Omega^{2}$ & $Z_{\mathrm{B}}, \Omega^{3}$ & $Z_{\mathrm{B}}, \Omega^{1}$ & $Z_{\mathrm{B}}, \Omega^{2}$ & $Z_{\mathrm{B}}, \Omega^{3}$ \\
\hline 0,1 & 136,7 & 134,7 & 134,8 & 110,6 & 109,0 & 109,1 & 96,06 & 94,66 & 94,72 & 66,55 & 65,58 & 65,61 \\
\hline 0,2 & 113,3 & 112,5 & 112,6 & 91,61 & 90,95 & 91,02 & 79,53 & 78,95 & 79,02 & 55,07 & 54,66 & 54,70 \\
\hline 0,4 & 90,95 & 90,38 & 90,48 & 73,44 & 72,97 & 73,05 & 63,72 & 63,31 & 63,38 & 44,07 & 43,78 & 43,84 \\
\hline 0,7 & 73,34 & 72,78 & 72,89 & 59,13 & 58,67 & 58,76 & 51,26 & 50,87 & 50,94 & 35,42 & 35,14 & 35,19 \\
\hline 1,0 & 62,23 & 61,88 & 61,99 & 50,10 & 49,82 & 49,90 & 43,41 & 43,16 & 43,24 & 29,97 & 29,79 & 29,84 \\
\hline 2,0 & 42,39 & 42,29 & 42,38 & 34,02 & 33,93 & 34,00 & 29,43 & 29,35 & 29,42 & 20,26 & 20,21 & 20,25 \\
\hline 4,0 & 26,44 & 26,45 & 26,50 & 21,13 & 21,14 & 21,18 & 18,25 & 18,25 & 18,28 & 12,53 & 12,53 & 12,56 \\
\hline
\end{tabular}

Pastabos: ${ }^{1}$ - vertė gauta taikant siūlomą modeli; ${ }^{2}$ - vertè gauta taikant momentų metodą (Urbanavičius, Martavičius 2006); 3 - vertė gauta taikant spektro srities (angl. spectral domain) metodą (Cheng, Everard 1991).

2.4 paveiksle pateikta būdingosios varžos, apskaičiuotos pagal siūlomą modeli $Z_{B}$ ir gautus kitų tyrèjų $Z_{\mathrm{B} 0}(2.1$ lentelè $)$ santykinio skirtumo $\delta Z_{\mathrm{B}}=\left(Z_{\mathrm{B}}-Z_{\mathrm{B} 0}\right) / Z_{\mathrm{B} 0} \cdot 100 \%$ priklausomybè nuo analizuojamos srities diskretizavimo tankio $W / W^{\prime}$ (čia $W^{\prime}-$ MPL signalinio laidininko plotį atitinkantis tinklelio žingsnių pradinis skaičius). Paveiksle matyti, kad didejjant MPL analizuojamos srities mazgų tankiui pradinès vertès atžvilgiu daugiau nei 2 kartus (t. y., kai signalinis laidininkas padalintas i daugiau nei 40 tinklelio mazgų, o dielektrinio pagrindo storis atitinkamai i daugiau nei 10 tinklelio mazgu) pagal siūlomą modeli, gauta būdingosios varžos vertè skiriasi nuo kitų tyrèjų verčių mažiau negu $1 \%$. Toliau didinant signalinio laidininko pločio ir dielektrinio pagrindo storio tinklelio mazgu skaičių t. y., kai $W / W^{\prime} \geq 4$, gaunamos didesnès diskretizacijos paklaidos ir santykinès būdingosios varžos reikšmė keičia ženklą. Kai MPL signalinio laidininko plotis užima mažiau nei 10 tinklelio mazgų $\left(W / W^{\prime} \leq 0,5\right)$, apskaičiuotos būdingosios varžos santykinis skirtumas tampa didesnis nei $2 \%$. Skirtumas dideja dèl pernelyg mažo dielektrinio pagrindo suskaidymo tinklelio žingsniais ( $h \leq 3$ tinklelio žingsnių).

BS metodu analizuojama MPL sritis yra uždaroji, t. y. iš visų pusių apribota laidžiuoju ekranu. Tuo atveju, kuomet tenka nagrinèti atvirają MPL, viršutinis ir šoniniai ekranai modelyje turi būti išdèstyti pakankamai toli nuo signalinio laidininko, kad neįnešti papildomos ilginès talpos. Būdingosios varžos skaičiavimo 


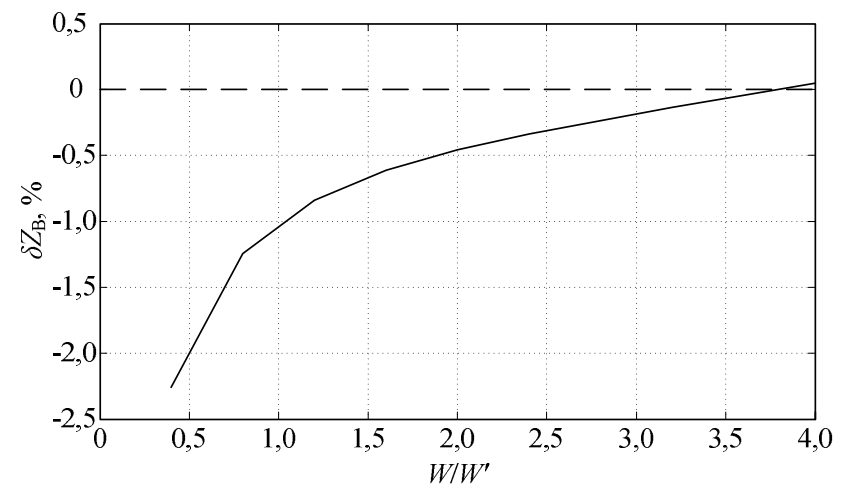

2.4 pav. Apskaičiuotos ir gautos kitų tyrèjų būdingosios varžos santykinio skirtumo priklausomybè nuo analizuojamos srities diskretizavimo tankumo, kai pradinis signalinio laidininko plotis $W^{\prime}=20$ tinklelio žingsnių;

$$
W / h=4,0 ; \varepsilon_{\mathrm{r}}=6,0
$$

Fig. 2.4. Calculated characteristic impedance relative difference with the other authors results dependence on mesh discretisation density, when initial signal conductor width $W^{\prime}=20$ mesh steps; $W / h=4.0 ; \varepsilon_{\mathrm{r}}=6.0$

tikslumo priklausomybes nuo šoninių ekranų atstumo BS metodu iteraciniu bei susietujjų matricų būdu, kai $W / h=4,0$ (2.5 pav.). Šiuo atveju MPL buvo padalinta ị 80 tinklelio žingsnių, o dielektrinis pagrindas - 20 žingsnių. 2.5 paveikslo kreivių analizè rodo, kad, kai nagrinejjama sritis palyginus nedidelè (analizuojamos srities kraštinè mažesnè nei 150 tinklelio žingsnių t. y. $g / h<7,5)$, būdingosios varžos santykinis skirtumas $\delta Z_{\mathrm{B}}$ yra didesnis nei $5 \%$. Santykinis skirtumas šiuo atveju dideja dèl arti esančių šoninių ekranų. Taigi, darytina išvada, kad MPL yra uždaroji, kai atstumas nuo signalinio laidininko krašto iki šoninio ekrano neviršija dviejų laidininko pločių t. y. $g / W \leq 2$.

Ieškant potencialo pasiskirstymo pagal BS metodo iteracinị būdą, būtina nurodyti skaičiavimo paklaidą $\delta$. Natūralu, kad kuo mažesnè $\delta$, tuo tikslesnis gaunamas potencialo pasiskirstymas, tačiau skaičiavimo procesas trunka žymiai ilgiau. 2.5 paviksle pateiktos būdingosios varžos skaičiavimo santykinio skirtumo priklausomybès nuo skaičiavimo paklaidos ir analizuojamos srities dydžio. Paveiksle matyti, kad skaičiuojant potencialo pasiskirstymą iteraciniu būdu su nustatyta skaičiavimo paklaida $\delta=10^{-5}$, gautų rezultatų tikslumas yra nepakankamas. Šiuo atveju net didinant analizuojamos srities dydi, potencialo pasiskirstymas nearteja prie atvirosios MPL potencialo pasiskirstymo ir apskaičiuotos būdingosios varžos vertès nenusistovi ties atvirosios MPL būdingaja varža. 


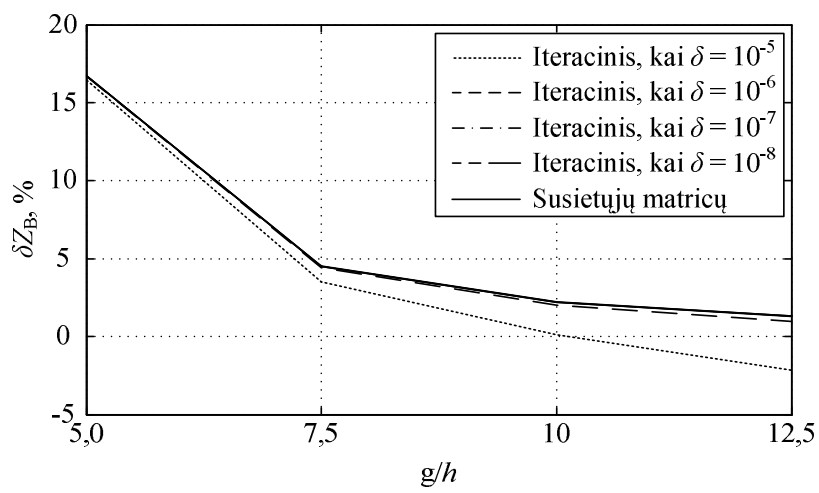

2.5 pav. Apskaičiuotos ir gautos kitų tyrejjų būdingosios varžos santykinio skirtumo priklausomybè nuo skaičiavimo paklaidos ir analizuojamos srities dydžio, kai $h=20$ tinklelio žingsnių; $W / h=4,0 ; \varepsilon_{\mathrm{r}}=6,0$

Fig. 2.5. Calculated characteristic impedance relative difference with the other authors results dependence on calculation errors and area size, when

$$
h=20 \text { mesh steps; } W / h=4.0 ; \varepsilon_{\mathrm{r}}=6.0
$$

Nagrinejjant kokiomis sąlygomis esant, mikrojuostelinę liniją galima laikyti atviraja, keičiamas nagrinėjamos srities dydis. Susietujų matricų būdu apskaičiuotų būdingujuc varžų dydžių santykinio skirtumo $\delta Z_{\mathrm{B}}$ priklausomybès nuo analizuojamos srities dydžio ir ivvairių MPL dielektrinio pagrindo skvarbų, kai signalinio laidininko plotis sąlyginai platus $(W / h=4,0)$ ir siauras $(W / h=0,2)$, pateiktos 2.6 paveiksle (a) ir (b) atitinkamai. Siekiant priarteti prie atvirosios MPL modelio, grịsto baigtinių skirtumų metodu, analizuojama sritis plečiama, t. y. tolinami ekranai iš šonu ir viršaus, paliekant nepakitusius MPL konstrukcinius parametrus $W$ ir $h$. Kai analizuojama sritis sąlyginai maža $(m / h \leq 7,5)$, būdingosios varžos dydžiui didelę itaką daro arti esantys ekranai ir santykinis skirtumas $\delta Z_{\mathrm{B}}$ viršija $10 \%$. Be to, dèl mažo integravimo kontūrą sudarančių žingsnių skaičiaus, skaičiuojant signalinių laidininkų sukauptą krūvị, gaunamos didesnès apvalinimo paklaidos. Ekranams tolstant nuo signalinio laidininko būdingosios varžos reikšmè artèja prie atvirosios mikrojuostelinès linijos būdingosios varžos reikšmès. Tarkime, kai analizuojamos srities kraštinė didesnè nei 200 mazgų $(m / h \geq 10)$, būdingosios varžos vertè, apskaičiuota pagal BS metodą, taikant susietujų matricų būdą, skiriasi nuo apskaičiuotų kitais metodais mažiau nei $2 \%$ nepriklausomai nuo pagrindo dielektrinès skvarbos $\varepsilon_{\mathrm{r}}$.

Būdingosios varžos skaičiavimo trukmės $t_{\mathrm{s}}$ priklausomybės nuo analizuojamos kvadratinès srities dydžio (kai srities kraštinès lygios $(m=n)$ ) iteraciniu 

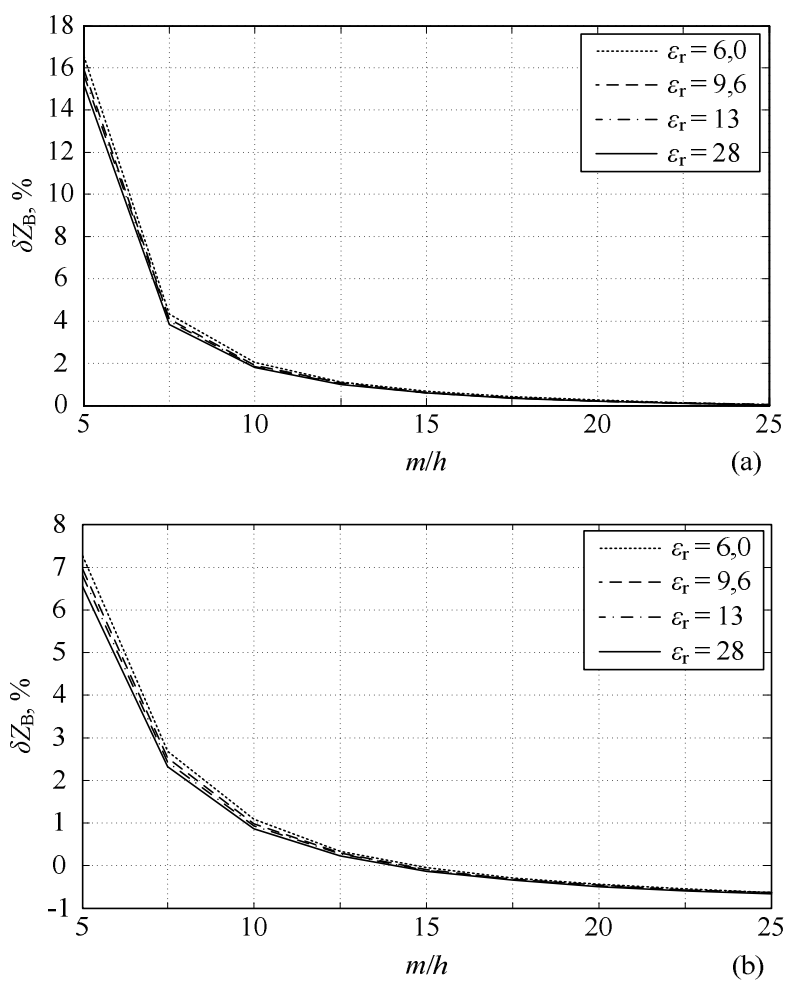

2.6 pav. Apskaičiuotos ir gautos kitų tyrèjų būdingosios varžos santykinio skirtumo priklausomybè nuo analizuojamos srities dydžio, kai $\varepsilon_{\mathrm{r}}=6,0$ ir a) $W / h=4,0$; b) $W / h=0,2$

Fig 2.6. Calculated characteristic impedance relative difference with the other authors results dependence on area size, when $\varepsilon_{\mathrm{r}}=6.0$ and

a) $W / h=4.0$; b) $W / h=0.2$

ir susietuju matricų būdais (2.7 pav.), kai $W / h=4,0$. Kai analizuojama sritis palyginus maža (analizuojamos srities kraštinè $m<150$ tinklelio žingsnių), skaičiavimai vyksta pakankamai sparčiai (mažiau $5 \mathrm{~s}$, taikant susietujų matricų būdą ir mažiau 6 minučių, taikant iteracinị būdą, esant tai pačiai kompiuterio konfigūracijai (PC suderinamas kompiuteris, $\mathrm{CPI}$ taktinis dažnis $-2 \mathrm{GHz}$, pagrindinès atminties talpa - 4 GB, operaciné sistema - MS Windows 7). Analizuojamai sričiai didejjant, didejja nežinomų potencialų verčiu skaičius ir skaičiavimo trukmé taip pat smarkiai didejja. Tarkime, kuomet analizuojamos srities dydis viršija 60000 taškų ( $m>250)$, taikant ịtaracininị būdą skaičiavimai gali trukti dešimtis minučių, o taikant susietųjų matricų būdą - dešimtis sekundžių. 


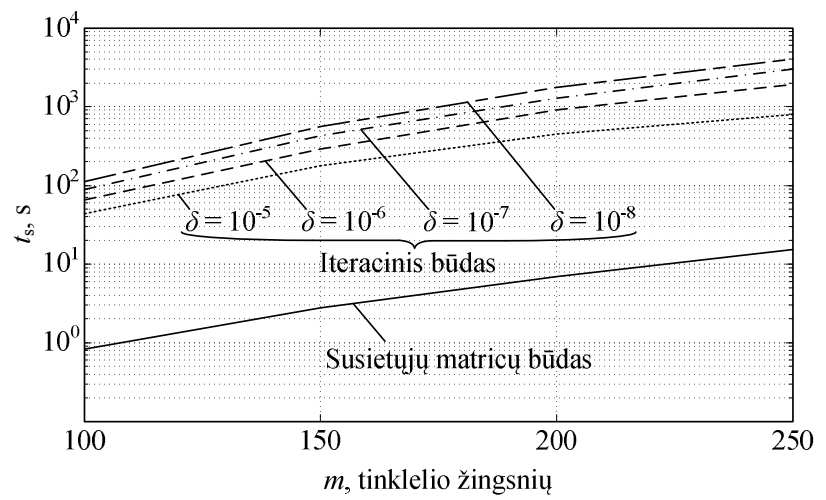

2.7 pav. Mikrojuostelinės linijos analizės trukmės priklausomybė nuo analizuojamos srities dydžio ir skaičiavimo būdo

Fig 2.7. Microstrip line analysis time dependence on analyzed area size and the method of calculation

Siekiant patikrinti būdingosios varžos skaičiavimo rezultatų priklausomybę nuo ilginès talpos skaičiavimo būdo, buvo atlikti skaičiavimai, taikant Gauso dèsni elektrinès indukcijos srautui (2.7) bei elektrinio lauko energijos sąvoką (2.9), (2.10). Skaičiavimo rezultatai pateikti 2.8 paveiksle.

Analizuojant 2.8 paveikslo kreives matyti, kad būdingosios varžos verčių

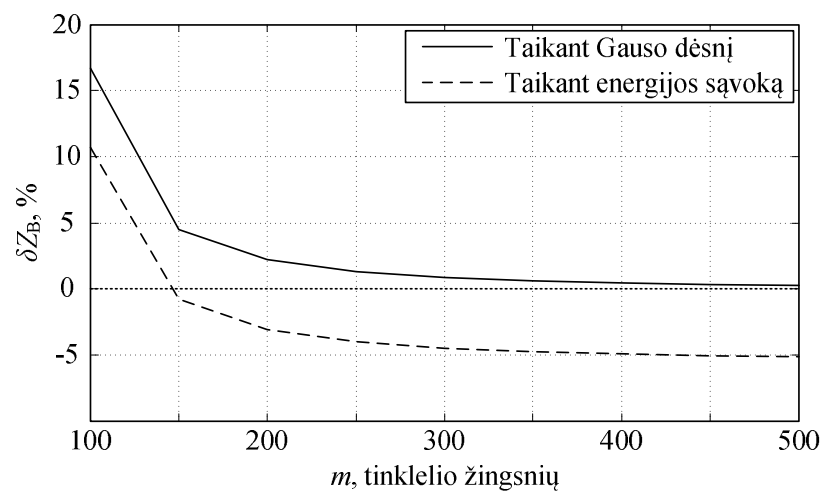

2.8 pav. Apskaičiuotos ir gautos kitụ tyrèjų būdingosios varžos santykinio skirtumo priklausomybè nuo skaičiavimo būdo ir analizuojamos srities dydžio, kai $h=20$ tinklelio žingsnių; $W / h=4,0 ; \varepsilon_{\mathrm{r}}=6,0$

Fig 2.8. Calculated characteristic impedance relative difference with the other authors results dependence on the method of calculation and area size, when $h=20$ mesh steps; $W / h=4.0 ; \varepsilon_{\mathrm{r}}=6.0$ 
kitimo pobūdis apskaičiuotas skirtingais būdais yra panašus. Būdingosios varžos, apskaičiuotos taikant Gauso dèsni elektrinès indukcijos srautui, santykinis skirtumas $\delta Z_{\mathrm{B}}$ skiriasi mažiau nei $1 \%$, kuomet analizuojamos srities dydis viršija 40000 tinklelio žingsnių ( $m>200$ ). Tačiau būdingosios varžos, apskaičiuotos taikant elektrinio lauko energijos sąvoką, santykinis skirtumas $\delta Z_{\mathrm{B}}$ pasiekia $5 \%$ didesnę vertę net didžiausios analizuojamos srities atveju (250 000 tinklelio žingsnių $(m=500))$. Šis skirtumas atsiranda dèl skaičių nukirtimo paklaidų, kurios pasireiškia esant beveik vienodų skaičių atimties veiksmams. Kadangi skaičiuojant elektrinio lauko sukauptą energiją vykdoma potencialų atimtis ir jų kèlimas kvadratu (2.11), o nuo signalinio laidininko nutolusių potencialų vertès yra mažos (artimos įžeminto ekrano potencialui) ir jų skirtumo kvadratas igauna vertes mažesnes nei $10^{-9} \mathrm{~V}^{2}$. Todèl didejant analizuojamos srities dydžiui apskaičiuota elektrinio lauko energija mažeja, o dèl šios priežasties būdingosios varžos vertė atitinkamai gaunama didesnè nei skaičiuojant kitais būdais.

\subsection{Mikrojuostelinès perdavimo linijos modelis, grịstas baigtinių skirtumų laiko srities metodu}

Šiame poskyryje nagrinèjama baigtinių skirtumų laiko srities (BSLS) metodo taikymo galimybè pavienès mikrojuostelinès perdavimo linijos analizei. Skaičiuojama linijos efektinè dielektrinè skvarba plačiame dažnių ruože bei vertinamas metodo tikslumas.

\subsubsection{Skaičiavimų algoritmas}

Modeliuojant MPL baigtiniu skirtumų laiko srities metodu, visa analizuojama sritis padalinama ị Yee gardeles (Yee 1966), kuriose išdėstomos elektrinių ir magnetinių laukų komponentès (2.9 pav.). Kiekviena elektrinio ir magnetinio lauko komponentė apskaičiuojama aproksimuojant dalinių išvestinių Maksvelo lygtis centrinių skirtumų lygtimis. Šių laukų komponentės skaičiuojamos visoje analizuojamoje srityje, kiekviename apskaičiuojamame laiko žingsnyje. Tam tikros lauko komponentès reikšmė priklauso nuo visų ją supančių esamų komponenčių ir nuo buvusių šios komponentès reikšmių.

Dèl baigtinių kompiuterio atminties resursų analizuojama atviroji MPL erdvè turi būti pakeista ị ribotą sriti, apsupant liniją absorbuojančiais sluoksniais. Šie sluoksniai modelyje taikomi siekiant nuslopinti bet kokias elektromagnetines bangas, pasiekiančias linijos atviruosius galus ir galinčias nuo šių galų atsispindèti bei sklisti atgaline kryptimi. Per daugeli metų nuo pirmo BSLS metodo pristatymo (Yee 1966) sukurta daug absorbuojančių sluoksnių variantų, kuriuos galima suskirstyti i analitinius, pvz.: Muro (Mur 1981), Higdono (Higdon 1986); 


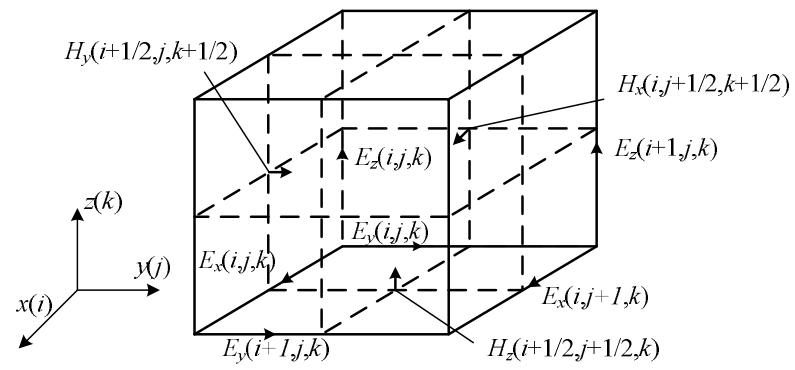

2.9 pav. Elektrinio ir magnetinio laukų komponenčių išdèstymas Yee gardeleje

Fig. 2.9. Yee cell with electric and magnetic field components positions

idealiai suderintus sluoksnius (angl. perfectly matching layer - PML), pvz.: vienaašius (Gedney 1996), konvoliucinius (Roden, Gedney 2000). Vadinamasis idealiai suderintas sluoksnis - tai tam tikro storio sluoksnis, gaubiantis analizuojamą sritị ir nuslopinantis ị ši sluoksnị krentančias elektromagnetines bangas. Bendruoju atveju absorbuojantis sluoksnis sudaromas taip, kad elektromagnetine banga, sklindanti analizuojamoje srityje neatsispindètų, t. y. analizuojamos srities ir absorbuojančio sluoksnio terpès būtų suderintos. Siūlomame MPL modelyje naudojamas vienaašis idealiai suderintas sluoksnis (angl. uniaxial perfectly matching layer). Šis vienaašis idealiai suderintas sluoksnis supa MPL iš visu pusių, išskyrus apatinị izžemintą laidujị ekraną (2.10 pav.).

Bendruoju atveju Maksvelo lygtys pagal BSLS metodą kartu su vienaašiu idealiai suderintu sluoksniu užrašomos taip (Taflove, Hagness 2005):

$$
\begin{gathered}
\nabla \times \vec{E}=-\mathrm{j} \omega \mu \vec{s} \vec{H}, \\
\nabla \times \vec{H}=\mathrm{j} \omega \varepsilon \vec{s} \vec{E},
\end{gathered}
$$

čia $\vec{E}$ ir $\vec{H}$ - elektrinio ir magnetinio laukų vektoriai; $\omega$ - kampinis dažnis; $\mu$ ir $\varepsilon-$ analizuojamos srities atitinkamai magnetinè ir dielektrinè skvarba; $\bar{s}$ - tenzorius, kuris aprašomas tokiu būdu:

$$
\bar{s}=\left[\begin{array}{ccc}
s_{x}^{-1} s_{y} s_{z} & 0 & 0 \\
0 & s_{x} s_{y}^{-1} s_{z} & 0 \\
0 & 0 & s_{x} s_{y} s_{z}^{-1}
\end{array}\right],
$$

čia $s_{x}, s_{y}$ ir $s_{z}$ - santykiniai kompleksinès dielektrinès skvarbos sandai atitinkamai $x, y$ ir $z$ kryptimis: 


$$
\begin{aligned}
& s_{x}=K_{x}+\frac{\sigma_{x}}{\mathrm{j} \omega \varepsilon}, \\
& s_{y}=K_{y}+\frac{\sigma_{y}}{\mathrm{j} \omega \varepsilon}, \\
& s_{z}=K_{z}+\frac{\sigma_{z}}{\mathrm{j} \omega \varepsilon} .
\end{aligned}
$$

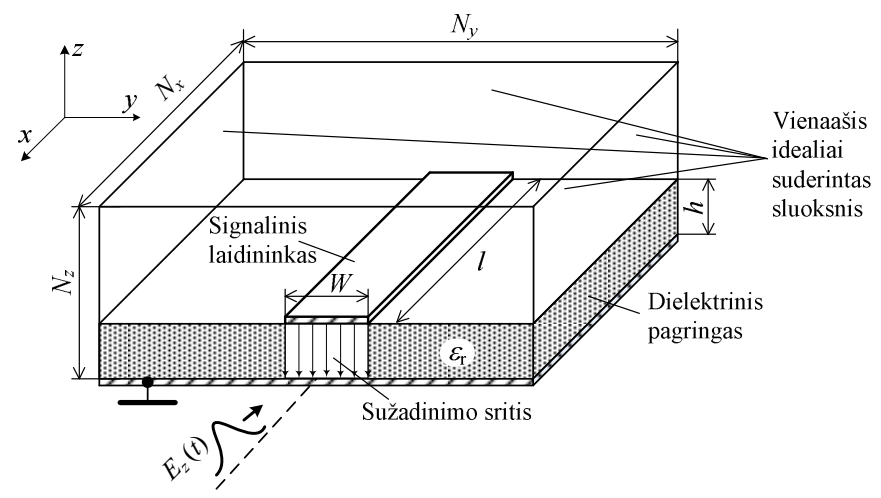

2.10 pav. Mikrojuostelinès linijos sandara skirta analizei baigtinių skirtumų laiko srities metodu

Fig. 2.10. Microstrip line structure for analysis by finite difference time domain method

Analizuojamoje srityje tenzoriaus $\bar{s}$ realiosios dalys $K_{i}$ prilyginamos vienetui, t. y. $K_{x}=K_{y}=K_{z}=1$, o elektriniai laidumai $\sigma_{x}, \sigma_{y}$ ir $\sigma_{z}$ apskaičiuojami atsižvelgus i medžiagos savybes tam tikroje gardelèje. Absorbuojančiame sluoksnyje tenzorių realiosios dalys ir elektriniai laidumai kinta, priklausomai nuo analizuojamo taško padèties sluoksnyje.

Krintančiosios elektromagnetinès bangos slopinimas absorbuojančiame sluoksnyje priklauso nuo bangos kritimo ị ši sluoksni kampo. Dél nevienodo pasiskirstymo elektrinio ir magnetinio lauku modelio analizuojamoje erdvejje (t. y. šių laukų komponentès pasiekia absorbuojanti sluoksni skirtingais laiko momentais) skaičiavimuose atsiranda atspindžių paklaidos. Siekiant sumažinti šias paklaidas Berenger (Berenger 1994) pasiūlè keisti idealiai sutampantị absorbuojantị sluoksnị i sluoksnius, kurių slopinimas kinta nuo 0 iki didžiausio nustatyto slopinimo dydžio. (Berenger 1994) darbe ši procedūra vadinosi gradavimu (angl. grading). Nuo absorbuojančio sluoksnio gardelių skaičiaus priklauso ir gradavimo lygių skaičius. Iprastai graduojama taikant geometrinès progresijos 
arba polinominès eilutès principą. Ju ịgyvendinimas analizuojamo įtaiso matematiniame modelyje nèra sudètingas ir vieno ar kito gradavimo principo parinkimas skaičiavimo rezultatams didesnès itakos neturi, todèl šiame darbe MPL modeliavimui pasirinktas polinominis gradavimas (Taflove, Hagness 2005):

$$
\begin{gathered}
\sigma_{i}(i)=\left(\frac{i}{d}\right)^{m} \sigma_{i, \max }, \\
K_{i}(i)=1+\left(K_{i, \max }-1\right) \cdot\left(\frac{i}{d}\right)^{m},
\end{gathered}
$$

čia $d$ - idealiai sutampančio absorbuojančio sluoksnio storis; $i$ - indeksas nurodantis krypti erdvèje $\left(x, y\right.$ ar $z$ ); $\sigma_{i, \max }$ - didžiausias sluoksnio laidumas; $m$ - gradavimo parametras, kurio dydi rekomenduojama parinkti tokiame ruože: $3 \leq m \leq 4$ (Berenger 1994). MPL skaičiavimams šis parametras parinktas 4 . Didžiausias sluoksnio laidumas apskaičiuojamas taip:

$$
\sigma_{i, \max }=-\frac{(m+1) \ln [R(\theta)]}{2 Z_{\mathrm{B}} d},
$$

čia $R(\theta)$ - atspindžių paklaida, kurios dydis parenkamas atsižvelgiant i absorbuojančio sluoksnio storị.

Skaičiavimų, grịstų BSLS metodu, tikslumas ir stabilumas priklauso nuo pasirinkto laiko žingsnio $\Delta t$ bei gardelès matmenų $\Delta x, \Delta y$ ir $\Delta z$. Skaičiavimų rezultatas taip pat priklauso nuo analizuojamos srities diskretizavimo paklaidų, kurios visoje nagrinejjamoje srityje, sudarytoje iš Yee gardelių, atsiranda dèl analizuojamos srities dispersiniu savybių ir anizotropijos, t. y. sklindančios bangos fazinis ir grupinis greičiai priklauso nuo dažnio ir sklidimo kampo. Siekiant, kad fazès skaičiavimo paklaida neviršytų $1^{\circ}$ per bangos ilgị, gardelès dydis rekomenduojamas (Gedney 2011):

$$
\Delta \leq \frac{\lambda_{\min }}{20},
$$

čia $\Delta=\Delta x=\Delta y=\Delta z$ gardelès dydis $x, y$ ir $z$ kryptimis; $\lambda_{\min }-$ mažiausias sužadinimo impulso bangos ilgis.

BSLS metodo stabilumas priklauso nuo laiko žingsnio $\Delta t$, kurio dydi apibrèžia Koranto (angl. Courant) sąlyga. Ši sąlyga susieja gardelès dydi $\Delta$ ir sklindančios bangos greitị nagrinėjamoje srityje. Kadangi nagrinėjama struktūra yra nevienalyte, t. y. sudaryta iš dielektrinio pagrindo ir oro $(2.10$ pav.), tai pasirenkamas tos terpès sklindančios bangos greitis, kurioje šis greitis didžiausias. Tuomet laiko žingsnis apibrěžiamas tokia išraiška (Taflove, Hagness 2005): 


$$
\Delta t=\frac{0,99}{\mathrm{c}_{0} \cdot \sqrt{\left(\frac{1}{\Delta x}\right)^{2}+\left(\frac{1}{\Delta y}\right)^{2}+\left(\frac{1}{\Delta z}\right)^{2}}} .
$$

Pagal BSLS metodą sudarytame itaiso modelyje elektrinis ir magnetinis laukai kinta laike, todèl ir jų sužadinimui turi būti naudojamas šaltinis, generuojantis laike kintantị signalą. Parenkant sužadinimo impulsą turi būti atsižvelgta ị sprendžiamo uždavinio pobūdį ir modeliuojamo įtaiso konstrukcijos ypatumus. Vienas iš dažniausiai naudojamų BSLS metodu grịstuose modeliuose sužadinimo impulsų - Gauso impulsas:

$$
E_{z}(t)=\exp \left[\frac{\left(t-t_{0}\right)^{2}}{t_{\mathrm{w}}^{2}}\right],
$$

čia $t_{0}$ - impulso uždelsimo trukmè, $t_{w}$ - impulso trukmè (plotis). Siekiant sumažinti aukštesnių dažnių triukšmus skaičiavimo rezultatuose, impulso uždelsimo trukmè turètų būti parinkta bent keturis kartus didesnè nei impulso trukmè. Gauso sužadinimo impulso spektro aukščiausia dažnio komponentẻ gali būti rasta pagal tokią formulę (Gedney 2011):

$$
f_{\mathrm{h}}=\frac{2}{\pi t_{\mathrm{w}}} .
$$

Sužadinimo impulsas MPL modelio ịejjime siunčiamas ị signalinị laidininką, esantị iškart už absorbuojančio sluoksnio. Signalinis laidininkas pratęsiamas ị absorbuojantị sluoksnị taip modeliuojant suderintą MPL bei apsaugant nuo atspindžių, atsiradusių esant nesuderintai apkrovai.

Pagal BSLS metodą galimi du sužadinimo būdai: kietasis bei minkštasis. Kietojo sužadinimo būdo atveju visą modeliavimo laiką elektrinio lauko stipris sužadinimo plokštumoje (2.10 pav.) priklauso nuo parinkto įtampos dydžio. Šiuo būdu modeliuojamas idealus ịtampos šaltinis ir bet kokios elektrinès bangos, krintančiosios ị sužadinimo sritị, atsispindès nuo jos kaip nuo idealaus laidininko. Siekiant modeliuoti ịtampos maitinimo šaltinị su tam tikra vidine varža, turi būti modifikuotos BSLS elektrinio lauko skaičiavimo lygtys atitinkamoje sužadinimo plokštumoje. Minkštojo sužadinimo atveju elektrinio lauko stipris sužadinimo plokštumoje priklauso nuo sklindančio ir sužadinamo elektrinių laukų superpozicijos. Šiuo atveju modeliuojamo šaltinio vidinè varža bus begalinè, t. y. atvira grandine - idealus srovès šaltinis. Siekiant imituoti realias MPL, modeliavimui buvo pasirinktas kietojo sužadinimo būdas.

BSLS metodu nagrinèjant mikrobanginius įrenginius skaičiuojamos įtampos, srovès, iejjimo varžos ir t. t. įvairiuose analizuojamos srities taškuose. Šiuo 
atveju minètų parametrų vertės yra tiesiogiai apskaičiuojamos iš elektrinio ir magnetinio laukų stiprio verčių.

Itampa tarp laidininko ir apatinio ekrano apskaičiuojama naudojant kvaziTEM artini, aproksimuojant elektrinio lauko skersines komponentes:

$$
U=\int_{L} \vec{E} \cdot \mathrm{d} \vec{l},
$$

čia $L$ - integravimo kelias tarp apatinio ekrano ir signalinio laidininko (2.11 pav., a); $\vec{E}$ - elektrinio lauko stiprio vektorius srityje tarp ekrano ir signalinio laidininko. Pritaikius (2.25) formulę BSLS metodui, diskrečiosios įtampos išraiška tampa:

$$
U^{t_{\mathrm{n}}+\frac{1}{2}}=\sum_{k=k_{1}}^{k_{2}-1} E_{z}^{t_{\mathrm{n}}+\frac{1}{2}}\left(i, j_{\mathrm{c}}, k\right) \cdot \Delta z,
$$

čia indeksai $k_{1}$ ir $k_{2}$ žymi atitinkamai apatinio ekrano bei signalinio laidininko apačios koordinatès $z$ ašies kryptimi; $j_{\mathrm{c}}$ - signalinio laidininko centro koordinatė $y$ ašies kryptimi; $t_{\mathrm{n}}$ - laiko žingsnis; $\Delta z$-gardelès žingsnis $z$ ašies kryptimi.

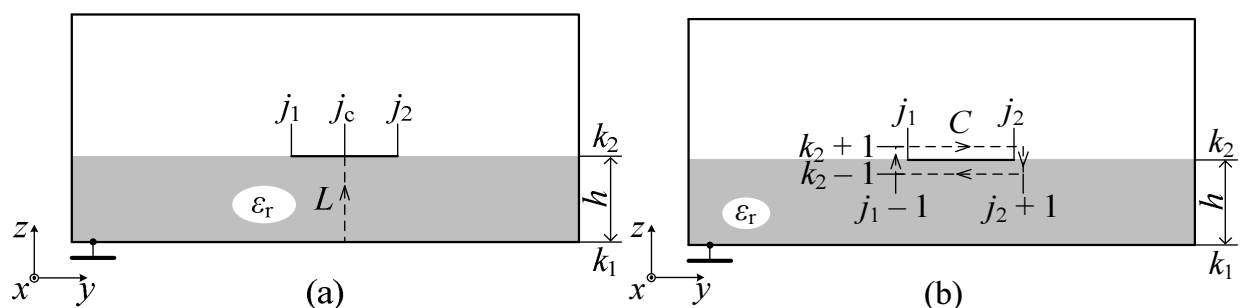

2.11 pav. İtampos (a) ir srovès (b) skaičiavimo mikrojuostelinės perdavimo linijos skerspjūvyje iliustracija

Fig. 2.11. Voltage (a) and current (b) calculation iliustration in cross section of microstrip transmission line

Panaudojant minètą kvazistatinị artinị, galima panašiai išreikšti sužadinimo impulso diskretuji elektrinio lauko stiprį:

$$
E_{z}^{t_{\mathrm{n}}+\frac{1}{2}}\left(i, j_{\mathrm{c}}, k\right)=-\frac{U^{t_{\mathrm{n}}+\frac{1}{2}}}{\Delta z \cdot h},
$$

čia $h$-dielektrinio pagrindo storis (gardelių skaičius $z$ kryptimi). Daroma prielaida, kad elektrinio lauko stipris po signaliniu laidininku (t. y. srityje tarp apatinio ekrano ir tašku $j_{1}$ bei $j_{2}$ ) yra vienodas. Impulso įtampos dydis bei ženklas modelyje gali būti parenkamas laisvai. 
Signaliniu laidininkais tekanti srovė apskaičiuojama naudojant kvazistatinę Ampero dèsnio aproksimaciją:

$$
I=\oint_{C} \vec{H} \cdot \mathrm{d} \vec{l},
$$

čia $C$ - kontūro apejjimo kelias srovei skaičiuoti (2.11 pav., b); $\vec{H}$ - magnetinio lauko stiprio vektorius srityje aplink signalinị laidininką. 2.11 pav., b matyti, kad kontūro apejjimo kelias yra arti signalinio laidininko ir skaičiavimams naudojama $H_{z}$ komponente yra išsidèsčiusi viena gardele toliau iš abiejų laidininko pusių, o $H_{y}$ komponentė yra toje pačioje gardelejje kaip ir signalinio laidininko viršutinis paviršius, bei viena gardele žemiau nei laidininko apatinis paviršius. Pritaikius (2.28) formulę BSLS metodui, diskrečiosios srovès išraiška tampa:

$$
\begin{aligned}
& I^{t_{\mathrm{n}}}=\sum_{j=j_{1}}^{j_{2}}\left[H_{y}^{t_{\mathrm{n}}}\left(i, j, k_{2}-\frac{1}{2}\right)-H_{y}^{t_{\mathrm{n}}}\left(i, j, k_{2}+\frac{1}{2}\right)\right] \cdot \Delta y+ \\
& +\left[H_{z}^{t_{\mathrm{n}}}\left(i, j_{2}+\frac{1}{2}, k_{2}\right)-H_{z}^{t_{\mathrm{n}}}\left(i, j_{1}-\frac{1}{2}, k_{2}\right)\right] \cdot \Delta z .
\end{aligned}
$$

Panaudojus (2.26) ir (2.29) išraiškas pagal BSLS metodą, gaunamos įtampos $U(t)$ ir srovès $I(t)$ laikinės charakteristikos, o atlikus šių charakteristikų Furje transformaciją gaunamos įtampos ir srovès kompleksinès dažninės charakteristikos:

$$
\begin{aligned}
& \underline{U}(\omega)=\int_{-\infty}^{\infty} U(t) \mathrm{e}^{-\mathrm{j} \omega t} \mathrm{~d} t, \\
& \underline{I}(\omega)=\int_{-\infty}^{\infty} I(t) \mathrm{e}^{-\mathrm{j} \omega t} \mathrm{~d} t .
\end{aligned}
$$

Magnetinio lauko komponentès $H_{z}$ ir $H_{y}$ erdvejje pasiskirsčiusios per puse gardelès žingsnio, o laiko atžvilgiu visos elektrinio ir magnetinio lauko komponentès pasiskirsčiusios per puse laiko žingsnio. Dèl šio nevienodo pasiskirstymo atsiranda skaičiavimo paklaidos ieškant kitų elektrinių parametrų (pvz.: būdingosios varžos, laidžio, iejjimo varžos ir t. t.). Siekiant išvengti šiu paklaidų (Gedney 2011) darbe siūloma apskaičiuoti srovès geometrini vidurkị analizuojamos srities skerspjūvyje bei pridèti prie įtampos fazès pusę laiko žingsnio:

$$
\begin{gathered}
\underline{U}(\omega)=\underline{U}(\omega) e^{-\mathrm{j} \omega \frac{\Delta t}{2}}, \\
\underline{I}(\omega)=\sqrt{\underline{I^{+}}(\omega)+\underline{I^{-}}(\omega),}
\end{gathered}
$$


čia $\underline{I}^{+}(\omega)$ - srovès kompleksinè dažninè charakteristika apskaičiuota, kai $H_{z}$ komponentè yra nutolusi per puse gardelès žingsnio $(\Delta x+1 / 2)$ toliau už analizuojamą skerspjūvị, $\underline{I}^{-}(\omega)$ - srovès kompleksinè dažninè charakteristika apskaičiuota, kai $H_{z}$ komponentè yra prieš skerspjūvị per puse gardelès žingsnio $(\Delta x-1 / 2)$.

Signalinio laidininko bangos fazès koeficiento dažninè charakteristika apskaičiuojama pagal tokią išraišką:

$$
\beta(\omega)=\frac{\varphi_{2}(\omega)-\varphi_{1}(\omega)}{\Delta x \cdot n_{x}},
$$

čia $\varphi_{1}(\omega)$ ir $\varphi_{2}(\omega)$ - analizuojamo signalinio laidininko atitinkamai ièjimo ir išèjimo signalų fazių priklausomybės nuo dažnio, $n_{x}$ - gardelių skaičius $x$ kryptimi tarp laidininko iejjimo ir išèjimo. Signalinio laidininko efektyviosios dielektrinès skvarbos priklausomybè nuo dažnio iš fazès koeficiento dažninès charakteristikos apskaičiuojama pagal tokią išraišką:

$$
\varepsilon_{\mathrm{ref}}(\omega)=\frac{\mathrm{c}_{0}^{2} \beta^{2}(\omega)}{\omega^{2}} .
$$

Būdingosios varžos dažninè priklausomybe apskaičiuojama iš ịtampos ir srovès dažninių charakteristikų santykio:

$$
Z(\omega)=\frac{U(\omega)}{I(\omega)} .
$$

Mikrojuostelinès linijos, grịstos baigtinių skirtumų laiko srities metodu, elektrinių parametrų skaičiavimo algoritmas pateiktas 2.12 paveiksle. Algoritmą sudaro 9 žingsniai:

1. Ivedami analizuojamos mikrojuostelinès linijos konstrukciniai parametrai: $h$ - dielektrinio pagrindo storis; $\varepsilon_{\mathrm{r}}$ - pagrindo dielektrinè skvarba; $l$-ilgis; $W$ - signalinio laidininko plotis; $d$ - absorbuojančio sluoksnio storis. Inicializuojamos elektrinès $[D]$ ir magnetinès $[B]$ indukcijos, elektrinio $[E]$ bei magnetinio $[H]$ lauku stiprio matricos.

2. Inicializuojamos ir apskaičiuojamos absorbuojančio sluoksnio koeficientụ matricos.

3. Atsižvelgiant ị nurodytus konstrukcinius parametrus, analizuojamoje srityje formuojamas mikrojuostelinès linijos modelis. 
4. Pradedamas skaičiavimo ciklas. Skaičiavimas vykdomas tol, kol pasiekiamas maksimalus nurodytas laiko žingsnis $t_{\max }$.

5. Ciklas pradedamas, kai laiko žingsnis $t_{\mathrm{n}}$ lygus nuliui, kiekvieno sekančio ciklo metu laiko žingsnis inkrementuojamas.

6. MPL kiekvienu ciklu perskaičiuojamas Gauso sužadinimo impulsas. Sužadinimas vykdomas sudarant atitinkamo stiprio elektrinị lauką dielektrinio pagrindo pjūvyje (2.10 pav.) per visą signalinio laidininko plotą.

7. Kiekviename laiko žingsnyje perskaičiuojamas elektrinès ir mangnetinès indukcijos bei laukų stiprių komponenčių matricos. Taip pat kiekviename žingsnyje išsaugomos $E_{z}$ komponentès reikšmès MPL įejime ir išèjime.

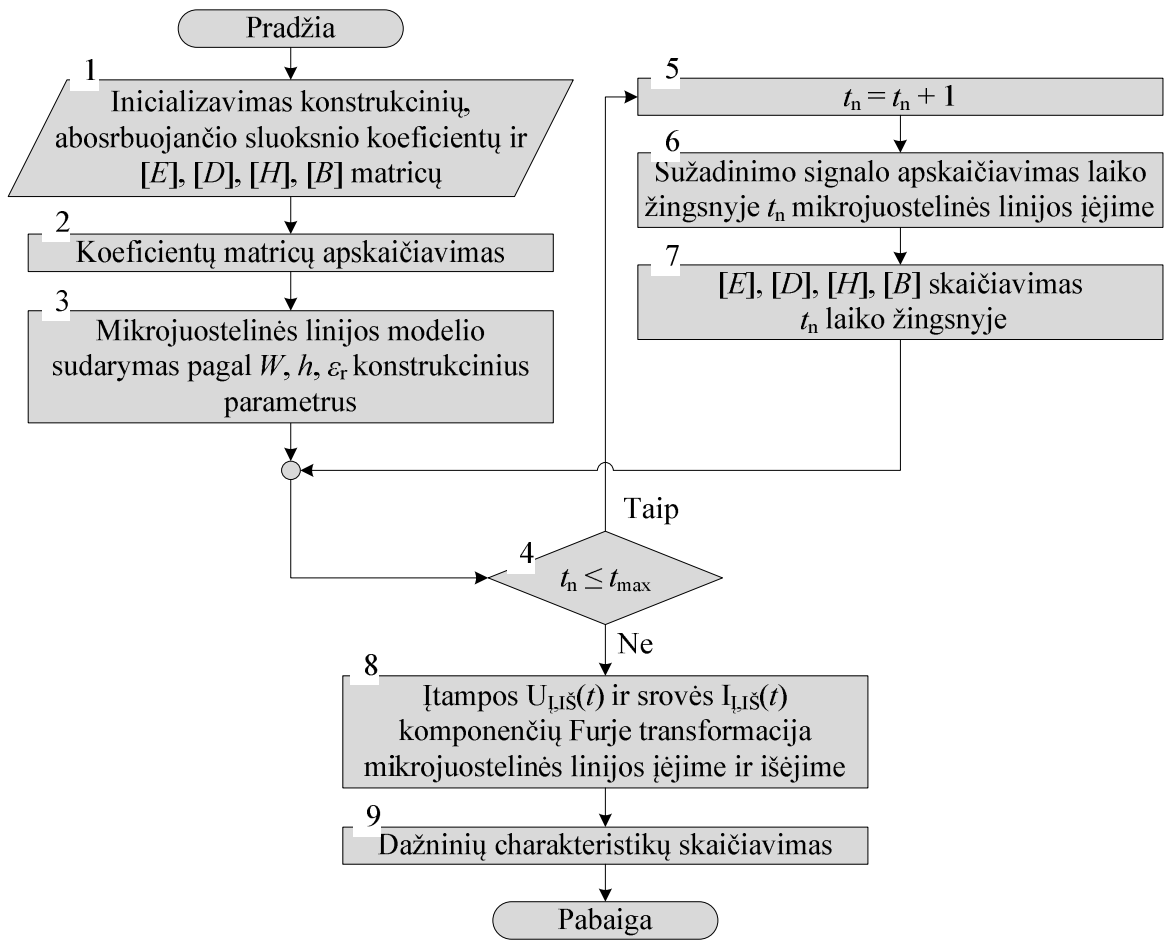

2.12 pav. Mikrojuostelinės linijos modelio, grịsto baigtinių skirtumų laiko srities metodu, supaprastintas algoritmas

Fig. 2.12. The simplified algorithm of the microstrip line model based on finite difference time domain method 


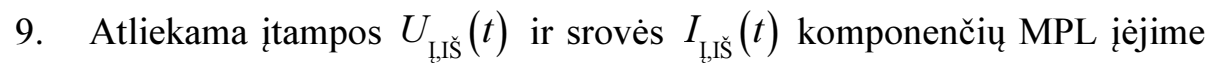
ir išejime Furje transformacija, gaunamos itampos ir srovès kompleksinès dažninès charakteristikos MPL įejime ir išèjime.

10. Iš įtampos kompleksinių dažninių charakteristikų apskaičiuojamos fazių dažninès priklausomybès MPL įejjime ir išèjime, o iš šių, pagal (2.34) išraišką, apskaičiuojama fazès koeficiento dažninè charakteristika $\beta(\omega)$. Iš bangos fazès koeficiento $\beta(\omega)$ apskaičiuojama efektinè dielektrinè skvarba. Iš ịtampos ir srovès kompleksinių dedamujų apskaičiuojama būdingoji varža.

\subsubsection{Mikrojuostelinès linijos modelio tyrimas}

Pasiūlytas mikrojuostelinès linijos modelis, grịstas BSLS metodu, buvo tiriamas dviem etapais: pirma, tikrinamas matematinio modelio adekvatumas lyginant ịvairių konstrukciniu parametrų MPL analizės rezultatus su kitų tyrejjų, kitais metodais gautais rezultatais; antra, tiriama konstrukciniu parametru ịtaka MPL efektinès dielektrinès skvarbos ir būdingosios varžos dažninèms priklausomybès.

\section{Modelio adekvatumas}

Publikacijose (York, Compton 1990) ir (Jain, Brown 1997) pateikti eksperimentinių MPL efektinès dielektrinès skvarbos matavimų rezultatai plačiame dažnių ruože. Atliekant skaičiavimus pagal siūlomą MPL modelį, linijos konstrukciniai parametrai buvo parinkti tokie patys kaip ir šių tyrejjų matuojamų įtaisų.

Darbe (York, Compton 1990) pateikti MPL dispersinès charakteristikos matavimų, atliktų pagal susietųjų plyšinių rezonatorių metodą 1-18 GHz dažnių ruože, rezultatai. Šio darbo bei pagal siūlomą MPL modeli gauti skaičiavimų rezultatai pateikti 2.13 paveiksle. Analizuojamos MPL konstrukciniai parametrai: dielektrinio pagrindo skvarba $\varepsilon_{\mathrm{r}}=9,8$; pagrindo storis $h=0,655 \mathrm{~mm}$; signalinio laidininko pločio ir pagrindo storio santykis $W / h=0,85$. Analizuojama sritis suskaidyta ị kubines gardeles, kurių diskretizacijos intervalas $\Delta$ parinktas 10 kartų mažesnis nei MPL konstrukcijos mažiausias parametras (pagrindo storis $h$ ). Tokios intervalo reikšmès parinkimas leidžia skaičiuoti plačiame dažnių diapazone ir išvengti diskretizacijos klaidų aukštuose dažniuose. 2.13 paveiksle pateiktų charakteristikų analizè rodo, kad pagal siūlomą MPL modelị apskaičiuotų ir išmatuotų charakteristikų santykinis skirtumas neviršija $3 \%$. Pastebètina, kad santykinis skirtumas yra mažesnis nei $1 \%$, kai analizuojamas dažnis didesnis nei $10 \mathrm{GHz}$ ir skirtumas didèja dažniui mažejjant, ir nors dažninių charakteristikų santykinis skirtumas nèra didelis, tačiau lyginant su momentų meto- 


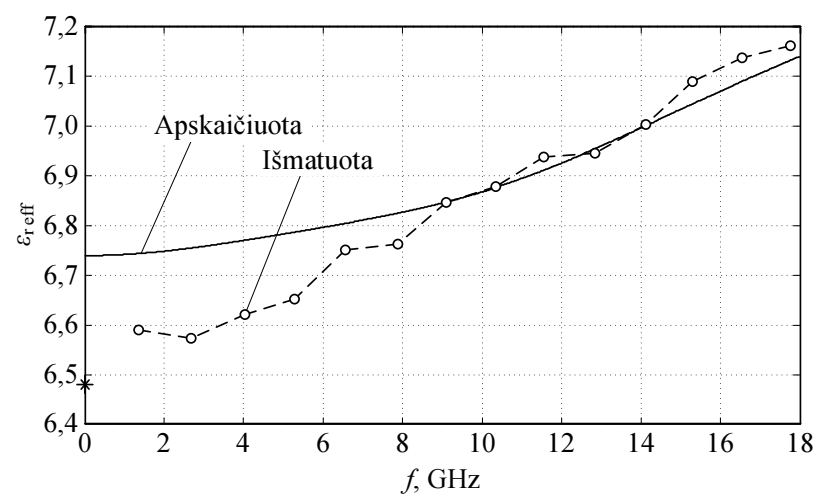

2.13 pav. Mikrojuostelinès linijos santykinès efektyvios dielektrinès skvarbos apskaičiuotos pagal siūlomą modelị (ištisinè linija) ir eksperimentiškai išmatuota (York, Compton 1990) darbe (brūkšninė linija) dažninès priklausomybès, kai $\varepsilon_{\mathrm{r}}=9,8 ; h=0,655 \mathrm{~mm} ; W / h=0,85$.

Žvaigždute pažymèta momentų metodu apskaičiuota vertè

Fig. 2.13. Effective permittivity of microstrip line, calculated by proposed model (solid curves) and measured (dashed curves) in (York, Compton 1990) work dependency on frequency, when $\varepsilon_{\mathrm{r}}=9.8 ; h=0.655 \mathrm{~mm}$;

$W / h=0.85$. Values calculated using the method of moments are pointed by asterisks

du apskaičiuota vertè statiniu atveju šis skirtumas siekia $4 \%$.

Darbe (Jain, Brown 1997) atlikti ant stiklo pagrindo $\left(\varepsilon_{\mathrm{r}}=4,0\right)$ pagamintų MPL efektyviosios dielektrinès skvarbos dažninių charakteristikų matavimai, taikant susietujų plyšinių ir žiedinių rezonatorių metodus. Matuotos ir pagal siūlomą modeli apskaičiuotos dviejų skirtingo pločio mikrojuostelinių linijų ( $W / h=0,5$ ir $W / h=2,0)$ dispersinès charakteristikos pateiktos 2.14 paveiksle. Kaip ir anksčiau aprašytu atveju (2.13 pav.) išmatuotų ir apskaičiuotų verčių santykinis skirtumas neviršija $3 \%$, o kreivių kitimo pobūdis išlieka panašus visame dažnių diapazone ir nepriklauso nuo MPL signalinio laidininko pločio t. y. santykinis skirtumas išlieka $3 \%$ ribose.

\section{Konstrukcinių parametrų ịtaka MPL dažninèms charakteristikoms}

Isitikinus siūlomo modelio adekvatumu ir nustačius, kad gaunami skaičiavimų rezultatai skiriasi nuo kitų tyrejų eksperimentiškai išmatuotų ne daugiau kaip $3 \%$, išanalizuota konstrukcinių parametrų įtaka MPL būdingosios varžos ir efektyviosios dielektrinès skvarbos dažninėms priklausomybėms. 


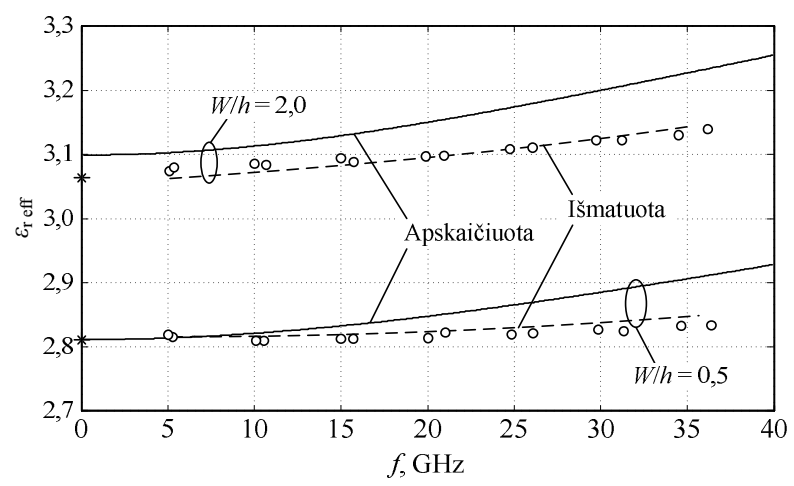

2.14 pav. Mikrojuostelinès linijos santykinès efektyvios dielektrinès skvarbos apskaičiuotos pagal siūlomą modelị (ištisinė linija) ir eksperimentiškai išmatuota (Jain, Brown 1997) darbe (brūkšninė linija) dažninès priklausomybès, kai $\varepsilon_{\mathrm{r}}=4,0 ; h=0,2 \mathrm{~mm}$; Žvaigždute pažymėta momentų metodu apskaičiuota vertė

Fig. 2.14. Effective permittivity of microstrip line, calculated by proposed model (solid curves) and measured (dashed curves) in (Jain, Brown 1997)

work dependency on frequency, when $\varepsilon_{\mathrm{r}}=4.0 ; h=0.2 \mathrm{~mm}$. Values calculated using the method of moments are pointed by asterisks

Normalizuotos efektinès dielektrinès skvarbos priklausomybès nuo dažnio ir signalinio laidininko pločio pateiktos 2.15 paveiksle. Šiame paveiksle matyti, kad didejjant virpesių dažniui, visų analizuojamų MPL, ir siaurų $(W / h=0,2)$ ir plačių $(W / h=4,0)$, efektyvioji dielektrinè skvarba didèja, o plačiųjų MPL atveju net artejja prie pagrindo dielektrinès skvarbos vertès. Tai galima paaiškinti tuo, kad elektrinis laukas didejjant dažniui koncentruojasi dielektriniame pagrinde ir MPL efektyvioji dielektrinè skvarba tampa artimesnè dielektrinio pagrindo vertei. Taip pat pastebėtina, kad mikrojuostelinių linijų su siauresniais signaliniais laidininkai efektyviosios skvarbos pokytis, kintant dažniui, yra mažesnis negu platesnių laidininkų atveju (atitinkamai $7 \%$ ir $12 \%$ ). Šis kitimas taip pat gali būti paaiškintas tuo, kad MPL su platesniu laidininku didesnè elektrinio lauko dalis susikoncentravusi dielektriniame pagrinde ir, didejant dažniui, elektrinis laukas dielektrike ties platesniuoju laidininku koncentruojasi greičiau, negu ties siauresniuoju. 


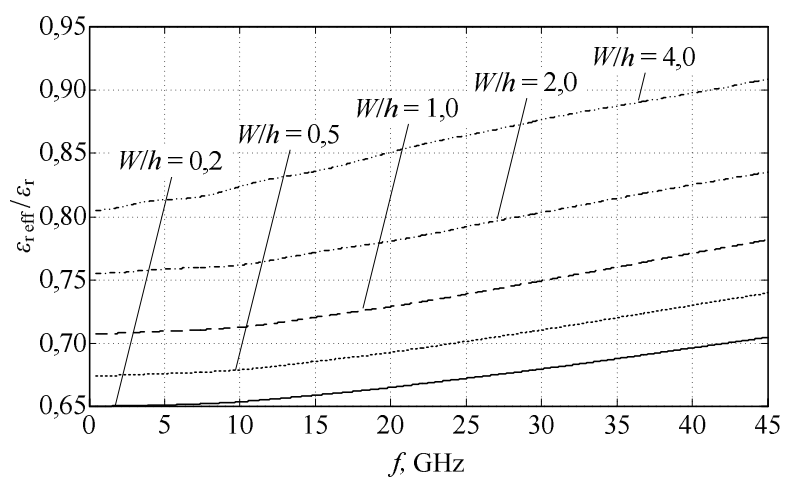

2.15 pav. Mikrojuostelinės linijos apskaičiuotų normalizuotų efektyviụjų dielektrinių skvarbų priklausomybè nuo dažnio su skirtingais $W / h$ ir

$$
\varepsilon_{\mathrm{r}}=6
$$

Fig. 2.15. Calculated normalized frequency dependencies of effective permittivity of microstrip line with different $W / h$ and $\varepsilon_{\mathrm{r}}=6$

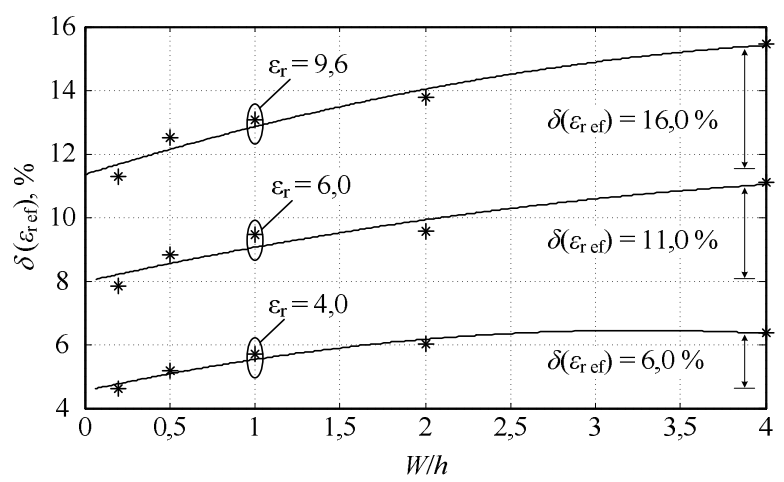

2.16 pav. Mikrojuostelinès linijos efektyviosios dielektrinès skvarbos santykinio pokyčio, didejjant dažniui, priklausomybės nuo signalinio laidininko pločio ir pagrindo dielektrinès skvarbos (žvaigždutėmis pažymėtos apskaičiuotos vertès, ištisinès kreivės - aproksimuotos priklausomybès)

Fig. 2.16. Dependences of the relative change of microstrip line effective permittivity of the at increase frequency, on the width of the microstrip and on a dielectric constant of the substrate (Calculated values marked as crosses, as solid lines - approximated values)

2.16 paveiksle pateiktos MPL efektyviosios dielektrinès skvarbos santykinio skirtumo priklausomybès nuo dažnio, signalinio laidininko pločio ir pagrin- 
do dielektrinès skvarbos. Santykinis dielektrinès skvarbos skirtumas, esant aukštiesiems ir žemiesiems dažniams:

$$
\delta\left(\varepsilon_{\text {ref }}\right)=\frac{\varepsilon_{\text {ref }}(45)-\varepsilon_{\text {ref }}(0)}{\varepsilon_{\text {ref }}(0)} \cdot 100 \%,
$$

čia $\varepsilon_{\text {r ef }}(45)$ - mikrojuostelinès linijos efektyviosios dielektrinès skvarbos vertè, apskaičiuota esant $45 \mathrm{GHz}$ virpesių dažniui (aukštieji dažniai); $\varepsilon_{\mathrm{ref}}(0)$ - efektyviosios dielektrinès skvarbos verte, apskaičiuota statiniam atvejui (žemieji daniai). 2.16 paveiksle matyti, kad efektyviosios dielektrinès skvarbos santykinis skirtumas aukštuose ir žemutiniuose dažniuose yra didesnis linijų, kurių pagrindo dielektrinè skvarba didesnè, nepriklausomai nuo signalinio laidininko pločio. Be to paveiksle matyti, kad platejjant signaliniam laidininkui nuo $W / h=0,2$ iki $W / h=4,0$, santykinès dielektrinès skvarbos skirtumas taip pat labiau didejja linijose, kurių pagrindo dielektrinè skvarba didesnè $\left(\delta\left(\varepsilon_{\mathrm{r} \text { ef }}\right) \cong 16 \%\right.$, kai $\varepsilon_{\mathrm{r}}=9,6$ ir $\delta\left(\varepsilon_{\mathrm{r} \text { ef }}\right) \cong 6 \%$, kai $\left.\varepsilon_{\mathrm{r}}=4,0\right)$.

\subsection{Antrojo skyriaus išvados}

Remiantis atliktais tyrimais ir jų rezultatų analize galima daryti šias išvadas:

1. Pasiūlyti mikrojuostelinių perdavimo linijų (MPL) modeliai, gristi baigtinių skirtumų (BS) ir baigtinių skirtumų laiko srities metodais (BSLS) bei susietujų matricų ir idealiai absorbuojančio sluoksnio būdais. Modeliai igyvendinti MATLAB ${ }^{\circledR}$ terpeje ir $\mathrm{C}, \mathrm{C}++$ programavimo kalbomis ir tinka atskleisti meandrinių lètinimo sistemų su labai dideliais tarpais tarp meandro strypų elektrinių parametrų kitimo pobūdi plačiame dažnių diapazone.

2. Tyrimai parodè, kad analizuojant MPL baigtinių skirtumų metodu, būtina suskaidyti linijos laidininko plotị ir dielektrinio pagrindo stori i ne mažiau kaip 5 tinklelio žingsnius, kitu atveju mažejja skaičiavimo tikslumas.

3. Taikant baigtinių skirtumų metodą ir susietujų matricų būdą potencialo pasiskirstymas MPL skerspjūvyje randamas išsprendus tiesinių lygčių sistemą. Tokio pobūdžio skaičiavimai atliekami žymiai sparčiau, nei taikant iteracinį būdą.

4. Tyrimai parodè, kad MPL būdingosios varžos vertè apskaičiuojama $5 \%$ tiksliau derinant BS metodą ir Gauso dèsnị elektrinès indukcijos srautui, nei taikant sukaupto elektrinio lauko energijos sąvoką. 
5. Tyrimai parodè, kad, taikant BSLS metodu grịstą MPL analizès modelį, elektrinių parametrų skaičiavimo rezultatai skiriasi nuo kitų autorių skelbiamų matavimų duomenų mažiau negu $3 \%$.

6. Mikrojuostelinès linijos analizè naudojant BS metodu grịstą modelị vyksta žymiai sparčiau, negu naudojant BSLS metodu grịstą modeli, esant tiems patiems kompiuterio ištekliams. Pavyzdžiui, naudojant PC suderinamą kompiuterị (CPI taktinis dažnis $-2 \mathrm{GHz}$, pagrindinès atminties talpa - 4 GB, operaciné sistema - MS Windows 7) ir taikant BS metodu grịstą modelį, MPL analizè trunka apie 120 sekundžių, o naudojant BSLS metodu grịstą modeli apie 120 minučių. Todèl BS metodas labiau tinka pradinei MPL konstrukcinių parametru sintezei, o susintezuotos linijos elektriniams parametrams plačiame dažnių diapazone analizuoti naudotinas BSLS metodas. 


\section{Daugialaidès mikrojuostelinès linijos modelio sudarymas ir tyrimas}

Daugelio lètinimo įtaisų, tame tarpe ir mikrojuostelinių, sandara yra periodine - sudaryta iš dielektriniame pagrinde reguliariai išdèstytų laidininkų. Tokị laidininkų išdèstymą atitinka daugialaide mikrojuostelinè linija, kuri yra plačiai naudojama modeliuojant periodinius lètinimo ịtaisus, reguliarias arba nereguliarias meandrines mikrojuostelines vèlinimo linijas.

Ankstesniame skyriuje nagrinètas baigtinių skirtumų ir baigtinių skirtumų laiko srities metodu taikymas mikrojuostelinių linijų analizei. Pastebèta, kad mikrojuostelinès linijos analizè, taikant baigtinių skirtumų metodą, trunka žymiai mažiau negu taikant baigtinių skirtumų laiko srities metodą. Taigi baigtinių skirtumu metodas tinkamesnis mikrojuostelinès linijos ir jos pagrindu sukurtu itaisu konstrukcinių parametrų sintezei, o baigtinių skirtumų laiko srities metodas laiko ir dažninèms charakteristikoms apskaičiuoti. Atsižvelgdami ị tai šiame skyriuje, sudaromi susietujjų ir daugialaidžių mikrojuostelinių linijų modeliai ir tiriamos šių linijų dažninių charakteristikų priklausomybės nuo konstrukcinių parametrų. Pateikiamos tolygios ir netolygios būdingosios varžos daugialaidès linijos sintezès metodikos.

Skyriaus tema paskelbti keturi autoriaus straipsniai (Pomarnacki et al. 2010; Pomarnacki, Krukonis 2011; Krukonis, Urbanavičius 2012; Krukonis, Mikučionis 2013). 


\subsection{Susietụjų mikrojuostelinių linijų modelis, grịstas baigtinių skirtumų laiko srities metodu}

Susietosios mikrojuostelinès linijos (SML) plačiai taikomos filtruose (Mohra 2009), rezonatoriuose (Bogdanov, Ludwig 2002), fazès keitikliuose (Sheng, Ong 2012) ir kituose mikrobangu elektronikos itaisuose. Be to, SML analizès metodika remiasi daugialaidžių mikrojuostelinių linijų modeliavimu. Siekiant suderinti SML ar jų pagrindu sudarytus įtaisus su kitų elektroninių prietaisų signaliniu traktu, būtina žinoti SML būdingosios varžos ir santykinès efektyviosios dielektrinès skvarbos dažnines charakteristikas.

Poskyryje pateikiamas susietujų mikrojuostelinių linijų matematinis modelis, gristas baigtiniu skirtumų laiko srities metodu (BSLS) ir idealiai suderinto absorbuojančio sluoksnio paradigma. Aptariamos siūlomos įtampos, srovès, būdingosios varžos ir efektyviosios dielektrinès skvarbos dažninių charakteristikų skaičiavimo metodikos.

\subsubsection{Susietujų mikrojuostelinių linijų modelis ir elektrinių pa- rametrų skaičiavimo metodikos}

Susietujų mikrojuostelinių linijų konstrukcijos eskizas pateiktas 3.1 paveiksle. Tokias konstrukcijas sudaro du mikrojuosteliniai signaliniai laidininkai suformuoti dielektrinio pagrindo paviršiuje. Signalinių laidininkų plotis $W_{i}$, gali skirtis. Tarpas $S$ tarp signalinių laidininkų lemia jų elektromagnetinį sąryšį. Šių laidininkų būdingoji varža ir efektyvioji dielektrinè skvarba priklauso nuo SML konstrukcinių parametrų: $W_{i}, S, h$ ir $\varepsilon_{\mathrm{r}}$ bei nuo signalinių laidininkų sužadinimo būdo.

SML itampos ir srovès dažninès charakteristikos tam tikruose analizuojamos srities taškuose apskaičiuojamos panašiu būdu kaip ir mikrojuostelinès linijos atveju, t. y. iš elektrinio ir magnetinio laukų stiprio verčių nurodytame taške, esant kvazi-TEM artiniui. İtampos tarp $i$-tojo signalinio laidininko ir apatinio ekrano apskaičiuojamos pagal tokią išraišką:

$$
U_{i}=\int_{L_{i}} \overrightarrow{E_{i}} \cdot \mathrm{d} \vec{l},
$$

čia $L_{i}$ - integravimo kelias tarp apatinio ekrano ir $i$-tojo signalinio laidininko (3.2 pav., a); $\overrightarrow{E_{i}}$ - elektrinio lauko stiprio vektorius srityje tarp ekrano ir $i$-tojo signalinio laidininko. Pritaikius (2.25) formulę BSLS metodui, diskrečiosios itampos išraiška tampa: 


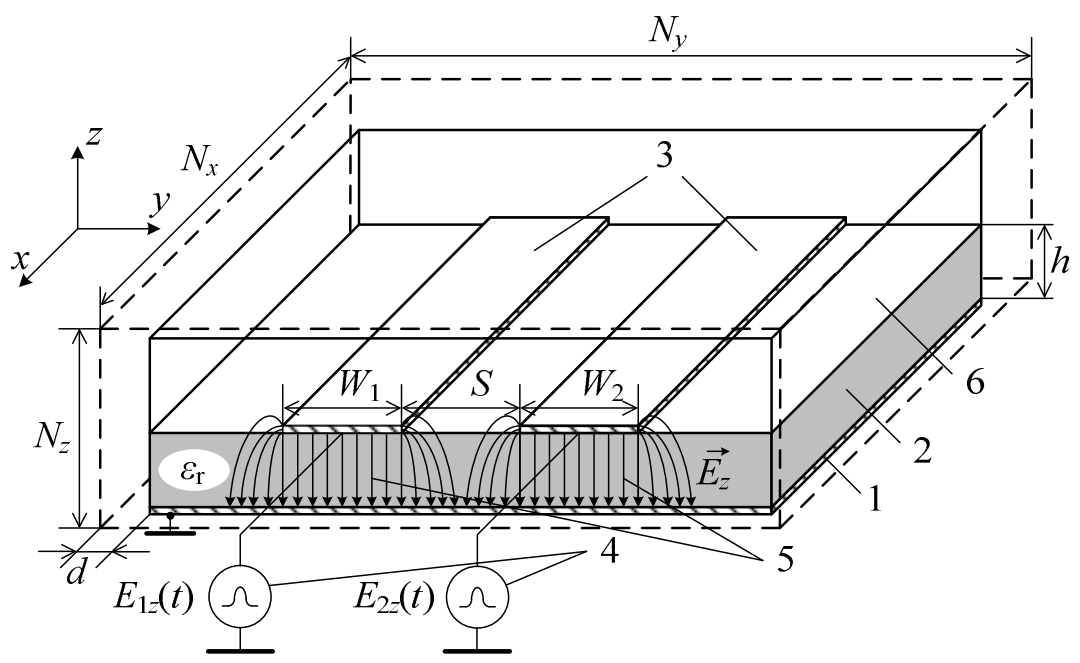

3.1 pav. Susietujų mikrojuostelinių linijų sandara skirta analizei BSLS metodu: 1 - ižemintas ekranas; 2 -dielektrinis pagrindas; 3 -signaliniai laidininkai; 4 - signalų šaltiniai; 5 - sužadinimo sritis (pažymèta tiesiomis, be šoninès sklaidos, elektrinio lauko stiprio jègos linijomis) skerspjūvyje;

6 - idealiai suderintas absorbuojantis sluoksnis

Fig. 3.1. Coupled microstrip structure for analysis by FDTD method:

1 - reference conductor; 2 - dielectric substrate; 3 - signal conductors;

4 - signal sources; 5 - excitation area (marked as straight, without side spread, electric field lines) in cross section; 6 - perfectly matching layer

$$
U_{i}^{t_{\mathrm{n}}+\frac{1}{2}}=\sum_{k=k_{1}}^{k_{2}-1} E_{z}^{t_{\mathrm{n}}+\frac{1}{2}}\left(i, j_{i \mathrm{c}}, k\right) \cdot \Delta z,
$$

čia indeksai $k_{1}$ ir $k_{2}$ žymi atitinkamai apatinio ekrano bei signalinio laidininko apačios koordinates $z$ ašies kryptimi; $j_{i c}-i$-tojo signalinio laidininko centro koordinatè $y$ ašies kryptimi; $t_{n}$ - laiko žingsnis; $\Delta z$-gardelès žingsnis $z$ ašies kryptimi.

Gauso sužadinimo impulso diskretusis elektrinio lauko stipris SML atveju išreiškiamas:

$$
E_{i z}^{t_{\mathrm{n}}+\frac{1}{2}}\left(i, j_{i \mathrm{c}}, k\right)=-\frac{U_{i}^{t_{\mathrm{n}}+\frac{1}{2}}}{\Delta z \cdot h},
$$

čia $h$-dielektrinio pagrindo storis (gardelių skaičius $z$ kryptimi). Daroma prielaida, kad elektrinio lauko stipris po tam tikru signaliniu laidininku (t. y. srityse 


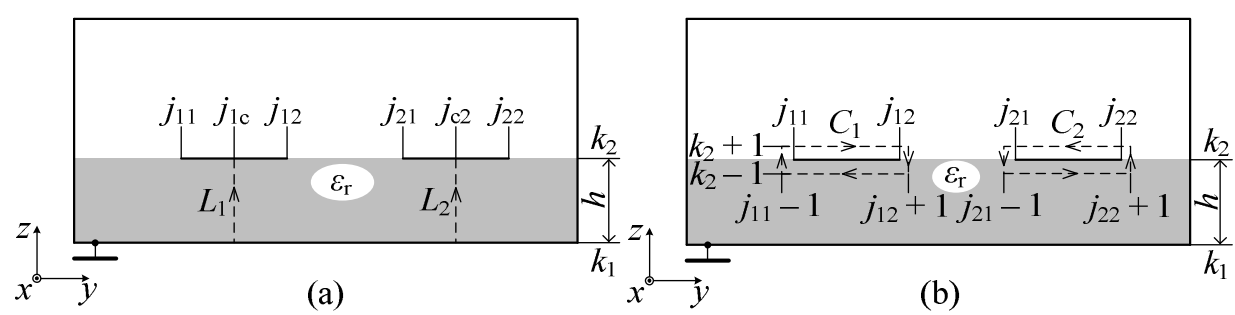

3.2 pav. İtampos (a) ir srovès (b) skaičiavimo susietujų mikrojuostelinių linijų skerspjūvyje iliustracija

Fig. 3.2. Voltage (a) and current (b) calculation iliustration in the cross section of coupled microstrip lines

tarp apatinio ekrano ir taškų $j_{11}, j_{12}$ bei $j_{21}, j_{22}$ ) yra vienalytis - nepaisoma lauko sklaidos ties laidininkų kraštais. Impulso įtampos dydis bei ženklas SML modelyje gali būti parenkamas laisvai.

Signaliniais laidininkais tekanti srovè apskaičiuojama naudojant kvazistatinę Ampero dèsnio aproksimaciją:

$$
I_{i}=\oint_{C_{i}} \overrightarrow{H_{i}} \cdot \mathrm{d} \vec{l},
$$

čia $C_{i}$ - kontūro apèjimo kelias $i$-tojo laidininko srovei skaičiuoti (3.2 pav., b); $\overrightarrow{H_{i}}$ - magnetinio lauko stiprio vektorius srityje aplink $i$-tajj signalinį laidininką. Pritaikius (2.28) formulę BSLS metodui, $i$-tojo signalinio laidininko diskrečiosios srovès išraiška tampa:

$$
\begin{aligned}
& I_{i}^{t_{\mathrm{n}}}=\sum_{j=j_{1}}^{j_{2}}\left[H_{y}^{t_{\mathrm{n}}}\left(i, j, k_{2}-\frac{1}{2}\right)-H_{y}^{t_{\mathrm{n}}}\left(i, j, k_{2}+\frac{1}{2}\right)\right] \cdot \Delta y+ \\
& +\left[H_{z}^{t_{\mathrm{n}}}\left(i, j_{2}+\frac{1}{2}, k_{2}\right)-H_{z}^{t_{\mathrm{n}}}\left(i, j_{1}-\frac{1}{2}, k_{2}\right)\right] \cdot \Delta z .
\end{aligned}
$$

Panaudojus (2.26) ir (2.29) išraiškas pagal BSLS metodą, gaunamos įtampos ir srovès laikinès charakteristikos, o atlikus šių charakteristikų Furje transformaciją, gaunamos įtampos ir srovès nurodytame taške dažninès charakteristikos.

$i$-tojo SML signalinio laidininko efektyviosios dielektrinès skvarbos priklausomybè nuo dažnio apskaičiuojama taip:

$$
\varepsilon_{i \mathrm{ref}}(\omega)=\frac{\mathrm{c}_{0}^{2} \beta_{i}^{2}(\omega)}{\omega^{2}} .
$$

i-tojo SML signalinio laidininko būdingosios varžos dažninès priklausomybès išraiška tampa: 


$$
Z_{i}(\omega)=\frac{U_{i}(\omega)}{I_{i}(\omega)} .
$$

\subsubsection{Susietujų mikrojuostelinių linijų modelio tyrimas}

Susietosioms mikrojuostelinès linijoms tirti BSLS metodu kompiuteriniame modelyje buvo sudaryta $200 \times 140 \times 40$ kubiniu gardeliu analizés sritis. Toks srities dydis parinktas siekiant modeliuoti tiek siaurus $\left(W_{1,2} \geq 0,159 \mathrm{~mm}\right)$, tiek plačius $\left(W_{1,2} \leq 3,175 \mathrm{~mm}\right)$ signalinius laidininkus. Parinktas absorbuojančio sluoksnio storis - 10 gardelių, kurių pakanka atspindžių paklaidai $R(\theta) \cong \mathrm{e}^{-16}$ pasiekti. Dielektrinio pagrindo storis parinktas $0,635 \mathrm{~mm}$ (Rodgers ${ }^{\circledR}$ imonès dvipusès folijuoto aukštadažnio dielektriko storis (Rodgers 2013)) ir ji sudaro 8 gardelès, laiko žingsnis apskaičiuojamas pagal (2.22) išraišką. Modelio tyrimams pasirinktos SML būdingosios varžos ir efektyviosios dielektrinès skvarbos dažninès charakteristikos, todèl, siekiant gauti šias charakteristikas plačiame dažnių ruože, susietosios linijos sužadinamos Gauso impulsu, kurio spektro plotis yra $35 \mathrm{GHz}$. Siekiant užtikrinti normaliujų bangų sklidimą susietosiose mikrojuostelinèse linijose, t. y. kai bangu sklidimo faziniai greičiai yra vienodi (angl. eigen mode), būtina laikytis tam tikrų žadinimo sąlygų:

- Vienodo pločio laidininkų susietosios linijos žadinamos lyginiu arba nelyginiu būdu, t. y. siunčiant ị laidininkus vienodo dydžio ir atitinkamai vienodo (angl. even mode) arba priešingo (angl. odd mode) ženklo įtampas.

- Skirtingo pločio laidininkų susietosios linijos žadinamos sinfaziniu (angl. c-mode) arba priešfaziniu (angl. $\pi$-mode) būdu, t. y. siunčiant i laidininkus tam tikro dydžio (itampų dydis priklauso nuo laidininko pločio) ir atitinkamai vienodo arba skirtingo ženklo įtampas.

Siūlomas susietuju mikrojuostelinių linijų modelis ištirtas dviem etapais. Pirma, atliekant SML analizę ir lyginant gautus skaičiavimo rezultatus su kitais metodais gautais rezultatais, įsitikinta modelio adekvatumu. Antra, išnagrinèta konstrukcinių parametrų ịtaka SML efektyviosios dielektrinès skvarbos ir būdingosios varžos dažninemis priklausomybèms.

\section{Modelio adekvatumas}

SML modelio, gristo BSLS metodu, adekvatumui patikrinti buvo sumodeliuotos ịvairaus signalinio laidininko pločio ir tarpo tarp jų susietosios linijos, veikiančios normaliujų bangų režimais. Apskaičiuotos jų efektyviosios dielektrinés skvarbos ir būdingosios varžos, o gautos vertès palygintos su vertemis, gautomis kitais analizès metodais. 
3.1-3.4 lentelèse pateikti SML, sužadintų lyginiu ir nelyginiu būdu, efektyviosios dielektrinès skvarbos ir būdingosios varžos vertès, gautos pagal siūlomą modelį, esant žemiesiems dažniams, ir apskaičiuotos pagal momentu metodą kvazistatiniam artiniui. Lentelèse taip pat pateikti minètų dydžių santykiniai skirtumai:

$$
\delta \varepsilon_{\mathrm{ref}}=\frac{\varepsilon_{\mathrm{ref}}(0)-\varepsilon_{\mathrm{ref}}^{\mathrm{MoM}}}{\varepsilon_{\mathrm{ref}}^{\mathrm{MoM}}} \cdot 100 \%,
$$

čia $\varepsilon_{\mathrm{r} \text { ef }}(0)$ ir $\varepsilon_{\mathrm{r} \text { ef }}^{\mathrm{MoM}}$ - atitinkamai SML santykinè efektyvioji dielektrinè skvarba, esant žemiesiems dažniams, apskaičiuota pagal siūlomą modelị ir kvazistatinị artinị, apskaičiuotą pagal momentų metodą:

$$
\delta Z_{\mathrm{B}}=\frac{Z_{\mathrm{B}}(0)-Z_{\mathrm{B}}^{\mathrm{MoM}}}{Z_{\mathrm{B}}^{\mathrm{MoM}}} \cdot 100 \%,
$$

čia $Z_{\mathrm{B}}(0)$ ir $Z_{\mathrm{B}}^{\mathrm{MoM}}$ - atitinkamai SML būdingosios varžos, esant žemiesiems dažniams, apskaičiuotos pagal siūlomą modelị ir kvazistatinị artinị, apskaičiuotą pagal momentų metodą.

3.1 lentelè. Susietujų mikrojuosteliniụ linijų, veikiančių lyginės normaliosios bangos režimu, santykinès efektyviosios dielektrinès skvarbos ir būdingosios varžos vertès, apskaičiuotos pagal baigtinių skirtumų laiko srities ir momentų metodą grịstus modelius bei šių dydžių santykiniai skirtumai, kai $\varepsilon_{\mathrm{r}}=9,6 ; h=0,635 \mathrm{~mm} ; S / h=1,0$

Table 3.1. Coupled microstrip lines, operated in even mode, relative effective permittivity and characteristic impedance values calculated by finite difference time domain and method of moments models and their values relative differences, when $\varepsilon_{\mathrm{r}}=9.6 ; h=0.635 \mathrm{~mm} ; S / h=1.0$

\begin{tabular}{|c|c|c|c|c|c|c|}
\hline$W / h$ & $\varepsilon_{\text {ref }}(0)$ & $\varepsilon_{\text {ref }}^{\mathrm{MoM}}$ & $\delta \varepsilon_{\text {ref }}, \%$ & $Z_{\mathrm{B}}(0), \Omega$ & $Z_{\mathrm{B}}^{\mathrm{MoM}}, \Omega$ & $\delta Z_{\mathrm{B}}, \%$ \\
\hline 0,25 & 7,16 & 6,36 & 12,6 & 95,5 & 96,9 & $-1,44$ \\
\hline 0,5 & 7,36 & 6,64 & 10,8 & 77,4 & 76,9 & 0,65 \\
\hline 1,0 & 7,67 & 6,99 & 9,73 & 57,1 & 56,2 & 1,60 \\
\hline 2,0 & 8,12 & 7,49 & 8,41 & 38,3 & 37,4 & 2,41 \\
\hline 5,0 & 8,75 & 8,21 & 6,58 & 19,5 & 19,5 & 0,00 \\
\hline
\end{tabular}


3.2 lentelè. Susietujų mikrojuostelinių linijų, veikiančių nelyginès normaliosios bangos režimu, santykinès efektyviosios dielektrinès skvarbos ir būdingosios varžos vertès, apskaičiuotos pagal baigtinių skirtumų laiko srities ir momentų metodą grịstus modelius bei šių dydžių santykiniai skirtumai, kai $\varepsilon_{\mathrm{r}}=9,6 ; h=0,635 \mathrm{~mm} ; S / h=1,0$

Table 3.2. Coupled microstrip lines, operated in odd mode, relative effective permittivity and characteristic impedance values calculated by finite difference time domain and method of moments models and their values relative differences, when $\varepsilon_{\mathrm{r}}=9.6 ; h=0.635 \mathrm{~mm} ; S / h=1.0$

\begin{tabular}{|c|c|c|c|c|c|c|}
\hline$W / h$ & $\varepsilon_{\text {ref }}(0)$ & $\varepsilon_{\text {ref }}^{\mathrm{MoM}}$ & $\delta \varepsilon_{\text {ref }}, \%$ & $Z_{\mathrm{B}}(0), \Omega$ & $Z_{\mathrm{B}}^{\mathrm{MoM}}, \Omega$ & $\delta Z_{\mathrm{B}}, \%$ \\
\hline 0,25 & 5,28 & 5,45 & $-3,12$ & 70,3 & 73,5 & $-4,35$ \\
\hline 0,5 & 5,40 & 5,55 & $-2,70$ & 57,8 & 57,7 & 0,17 \\
\hline 1,0 & 5,77 & 5,75 & 0,35 & 44,9 & 43,2 & 3,94 \\
\hline 2,0 & 6,42 & 6,14 & 4,56 & 31,45 & 30,1 & 4,49 \\
\hline 5,0 & 7,54 & 6,91 & 9,12 & 17,2 & 16,4 & 4,88 \\
\hline
\end{tabular}

3.3 lentelè. Susietujų mikrojuosteliniu linijų, veikiančių lyginės normaliosios bangos režimu, santykinès efektyviosios dielektrinès skvarbos ir būdingosios varžos vertès, apskaičiuotos pagal baigtinių skirtumų laiko srities ir momentų metodą grịstus modelius bei šių dydžių santykiniai skirtumai, kai $\varepsilon_{\mathrm{r}}=9,6 ; h=0,635 \mathrm{~mm} ; W_{1,2} / h=1,0$

Table 3.3. Coupled microstrip lines, operated in even mode, relative effective permittivity and characteristic impedance values calculated by finite difference time domain and method of moments models and their values relative differences, when $\varepsilon_{\mathrm{r}}=9.6 ; h=0.635 \mathrm{~mm} ; W_{1,2} / h=1.0$

\begin{tabular}{|c|c|c|c|c|c|c|}
\hline$S / h$ & $\varepsilon_{\mathrm{ref}}(0)$ & $\varepsilon_{\mathrm{ref}}^{\mathrm{MoM}}$ & $\delta \varepsilon_{\mathrm{ref}}, \%$ & $Z_{\mathrm{B}}(0), \Omega$ & $Z_{\mathrm{B}}^{\mathrm{MoM}}, \Omega$ & $\delta Z_{\mathrm{B}}, \%$ \\
\hline 0,25 & 7,56 & 6,95 & 8,78 & 65,3 & 63,2 & 3,32 \\
\hline 0,5 & 7,60 & 6,99 & 8,73 & 61,8 & 60,2 & 2,66 \\
\hline 1,0 & 7,67 & 6,99 & 9,73 & 57,1 & 56,2 & 1,60 \\
\hline 2,0 & 7,51 & 6,88 & 9,16 & 53,5 & 52,6 & 1,71 \\
\hline 5,0 & 7,23 & 6,60 & 9,55 & 51,6 & 50,6 & 1,98 \\
\hline
\end{tabular}


3.4 lentelè. Susietujų mikrojuostelinių linijų, veikiančių nelyginès normaliosios bangos režimu, santykinès efektyviosios dielektrinès skvarbos ir būdingosios varžos vertès, apskaičiuotos pagal baigtinių skirtumų laiko srities ir momentų metodą grịstus modelius bei šių dydžių santykiniai skirtumai, kai $\varepsilon_{\mathrm{r}}=9,6 ; h=0,635 \mathrm{~mm} ; W_{1,2} / h=1,0$

Table 3.4. Coupled microstrip lines, operated in even mode, relative effective permittivity and characteristic impedance values calculated by finite difference time domain and method of moments models and their values relative differences, when $\varepsilon_{\mathrm{r}}=9.6 ; h=0.635 \mathrm{~mm} ; W_{1,2} / h=1.0$

\begin{tabular}{|c|c|c|c|c|c|c|}
\hline$S / h$ & $\varepsilon_{\mathrm{ref}}(0)$ & $\varepsilon_{\mathrm{r} \text { ef }}^{\mathrm{MoM}}$ & $\delta \varepsilon_{\mathrm{ref}}, \%$ & $Z_{\mathrm{B}}(0), \Omega$ & $Z_{\mathrm{B}}^{\mathrm{MoM}}, \Omega$ & $\delta Z_{\mathrm{B}}, \%$ \\
\hline 0,25 & 5,39 & 5,52 & $-2,36$ & 31,6 & 33,0 & $-4,24$ \\
\hline 0,5 & 5,49 & 5,61 & $-2,14$ & 38,3 & 38,0 & 0,79 \\
\hline 1,0 & 5,77 & 5,75 & 0,35 & 44,9 & 43,2 & 3,94 \\
\hline 2,0 & 6,21 & 5,99 & 3,67 & 48,8 & 47,1 & 3,61 \\
\hline 5,0 & 6,69 & 6,28 & 6,53 & 50,7 & 49,3 & 2,84 \\
\hline
\end{tabular}

Analizuojant 3.1-3.4 lentelèse pateiktus duomenis matyti, kad SML efektyvioji dielektrinè skvarba, apskaičiuota pagal siūlomą modelị, visuomet yra didesnè nei skvarba, apskaičiuota pagal momentų metodą, ir lyginio ir nelyginio sužadinimo atveju. Didžiausias santykinis skirtumas efektyviosios dielektrinès skvarbos, apskaičiuotos skirtingais būdais, neviršija $13 \%$. Pastebėtina, kad būdingoji varža, apskaičiuota pagal siūlomą SML modelị, esant ịvairiems konstrukcinių parametrų deriniams, yra ir mažesnè, ir didesnė už varžą, gautą pagal momentų metodą, tačiau didžiausias santykinis skirtumas šiuo atveju neviršija 5 $\%$.

Pagal siūlomą SML modeli apskaičiuotų efektyviosios dielektrinès skvarbos ir būdingosios varžos dažninių priklausomybių adekvatumui patikrinti buvo sumodeliuota ir išanalizuota linija, kurios konstrukciniai parametrai atitinka (Jansen 1978) darbe integralinių lygčių metodu tiriamą liniją. Šios linijos analizès rezultatai pateikti 3.3 paveiksle.

Apskaičiuotos dažninių priklausomybių kreivès, pateiktos 3.3 paveiksle, rodo, kad BSLS metodu grịsto modelio ir integralinių lygčių metodo apskaičiuotų verčių santykinis skirtumas neviršija $6 \%$ efektyviosios dielektrinès skvarbos atveju ir $5 \%$ būdingosios varžos atveju. Pastebėtina, kad santykinis skirtumas yra mažesnis nei 5 \%, kai analizuojamas dažnis didesnis nei $12 \mathrm{GHz}$ ir skirtumas didèja dažniui mažèjant. Iš gautų rezultatų galima teigti, kad BSLS metodu grịsto modelio tikslumas yra pakankamas susietujų linijų analizei. 


\section{Konstrukcinių parametrų ịtaka SML dažninèms charakteristikoms}

Vienodo pločio susietuju linijų efektyviosios dielektrinès skvarbos ir būdingosios varžos dažninès priklausomybès lyginio sužadinimo atveju pateiktos 3.4 paveiksle, o priklausomybių santykiniai pokyčiai - 3.1 lentelèje. Analizuojant 3.4 paveikslo kreives matyti, kad, kaip ir pavienès mikrojuostelinès linijos atveju, platesnių signalinių laidininkų efektyvioji dielektriné skvarba yra didesné ir, didejjant dažniui, artèja prie pagrindo dielektrinès skvarbos. Kuo platesni signaliniai laidininkai, tuo skirtumas tarp efektyviosios dielektrinės skvarbos verčiu
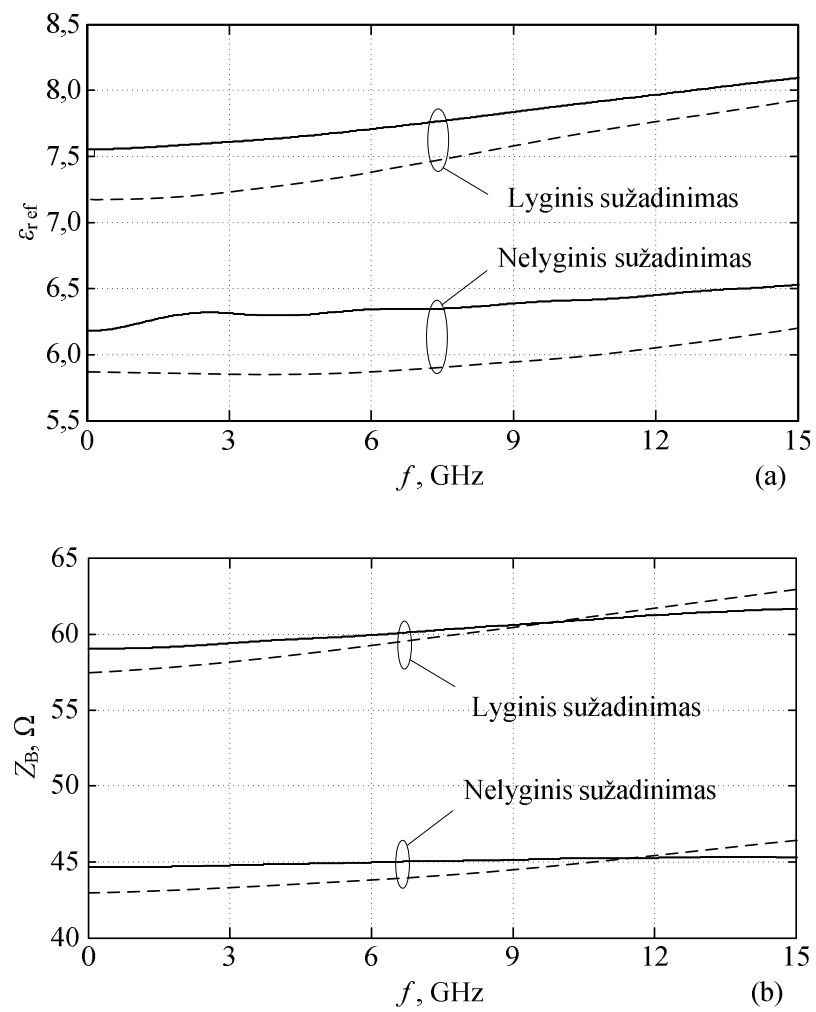

3.3 pav. Susietujų mikrojuostelinių linijų santykinės efektinès dielektrinės skvarbos (a) ir būdingosios varžos (b) dažninès priklausomybės, apskaičiuotos pagal baigtinių skirtumų laiko srities metodu grịstą modelị

(ištisinès linijos) ir pagal (Jansen 1978) integralinių lygčių metodą (brūkšninès linijos), kai $h=0,64 \mathrm{~mm}, W_{1,2}=0,6 \mathrm{~mm} ; S=0,6 \mathrm{~mm} ; \varepsilon_{\mathrm{r}}=9,6$ Fig. 3.3. Effective dielectric constant (a) and characteristic impedance (b) dependencies on frequency of coupled microstrip line, calculated by finite difference time domain method model (straight lines) and by (Jansen 1978) integral equation method (dashed lines), when $h=0.64 \mathrm{~mm} ; W_{1,2}=0.6 \mathrm{~mm}$;

$$
S=0.6 \mathrm{~mm} ; \varepsilon_{\mathrm{r}}=9.6
$$


aukštuosiuose dažniuose ir verčių žemuosiuose dažniuose yra mažesnis nei siauresnių laidininkų atveju (3.5 lentelè). Tai galima paaiškinti tuo, kad didžioji dalis elektrinio lauko yra susikoncentravusi dielektriniame pagrinde, esant platesniems signaliniams laidininkams, ir, didejjant dažniui, elektrinio lauko koncentracija pagrinde šiuo atveju padideja nežymiai. Panašus skirtumas pastebimas tarp siauresnių ir platesnių signalinių laidininkų būdingưjų varžų priklausomybių (3.4 pav., b). Lyginant žemuosiuose dažniuose efektyviosios dielektrinès skvarbos apskaičiuotas vertes su statiniu momentu metodu gautomis vertemis, nustatyta, kad santykinis skirtumas neviršija $13 \%$, o būdingosios varžos analogiškas santykinis skirtumas neviršija $5 \%$.

3.5 lentelè. Susietujų mikrojuostelinių linijų, veikiančių lyginès normaliosios bangos režimu, dažninių charakteristikų santykiniai pokyčiai

Table 3.5. Coupled microstrip lines, operated in even mode, relative changes of the frequency characteristics

\begin{tabular}{|c|c|c|}
\hline$W / h$ & $\delta \varepsilon_{\text {ref }}(f)^{*}$ & $\delta Z_{\mathrm{B}}(f)^{* *}$ \\
\hline 0,25 & 13,7 & 37,0 \\
\hline 0,5 & 13,8 & 22,0 \\
\hline 1,0 & 13,4 & 12,0 \\
\hline 2,0 & 11,4 & 15,0 \\
\hline 5,0 & 6,64 & 16,2 \\
\hline
\end{tabular}

Pastabos: ${ }^{*}-\delta \varepsilon_{\text {ref }}(f)=\left[\varepsilon_{\text {ref }}(30 \mathrm{GHz})-\varepsilon_{\text {ref }}(0)\right] / \varepsilon_{\text {ref }}(0) \cdot 100 \%$;

${ }^{* *}-\delta Z_{\mathrm{B}}(f)=\left[Z_{\mathrm{B}}(30 \mathrm{GHz})-Z_{\mathrm{B}}(0)\right] / Z_{\mathrm{B}}(0) \cdot 100 \%$.

Vienodo pločio, bet skirtingo tarpo tarp laidininkų susietosios mikrojuostelinès linijos efektyviosios dielektrinès skvarbos ir būdingosios varžos skaičiavimų rezultatai pateikti 3.5 paveiksle. Apskaičiuotos vertės žemuosiuose dažniuose buvo lyginamos su momentu metodu gautomis vertemis, kurios pažymètos kreives atitinkančiais simboliais. Kaip ir ankstesniame kompiuteriniame eksperimente, laidininkų pločių keitimo atveju (3.4 pav.), būdingosios varžos santykinis skirtumas, tarp dviem būdais (BSLS ir momentų metodu) gautų rezultatų, neviršija $3 \%$, efektyviosios dielektrinès skvarbos - $10 \%$. 3.5 paveiksle matyti, kad didejjant tarpui tarp susietujų mikrojuostelinių linijų laidininkų, būdingosios varžos vertès mažèja ir artėja prie atitinkamo pločio pavienès mikrojuostelinès linijos būdingosios varžos vertès, tačiau kreivių kitimo pobūdis, dažniui didèjant, išlieka toks pat. 

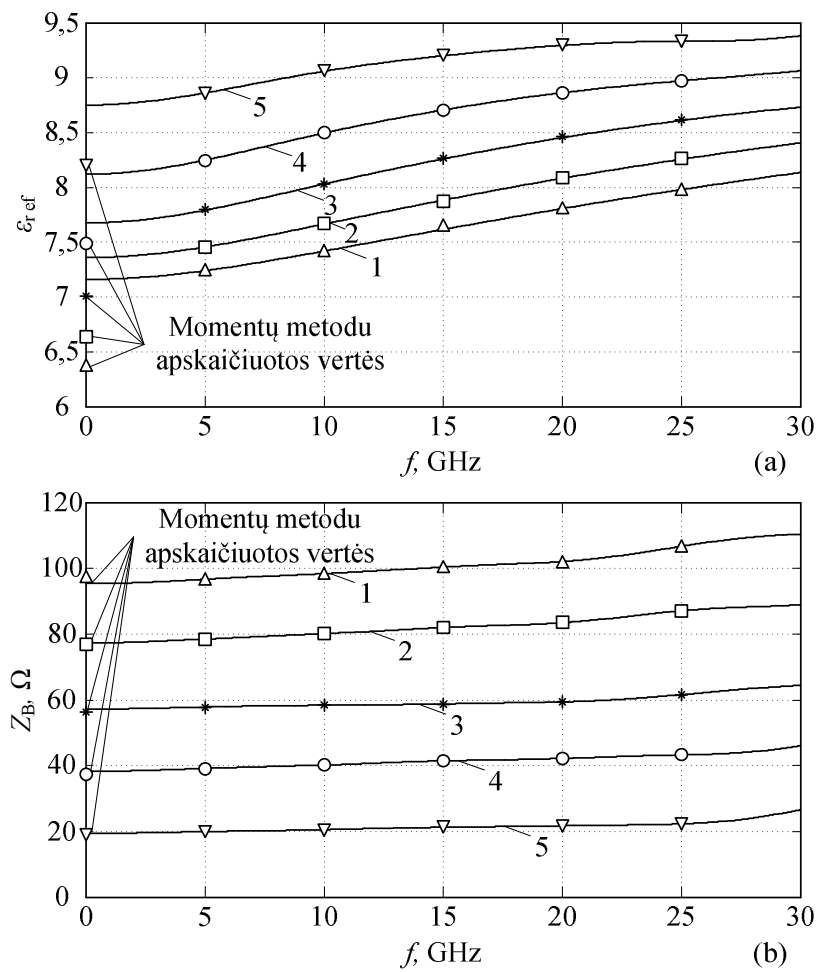

3.4 pav. Susietujų mikrojuostelinių linijų, veikiančių lyginių normaliụjų bangų režimu, efektyviosios dielektrinès skvarbos (a) ir būdingosios varžos

(b) priklausomybès nuo dažnio ir laidininkų pločio, kai $h=0,635 \mathrm{~mm}$, $W_{1} / h=W_{2} / h=W / h, S / h=1,0 ; \varepsilon_{\mathrm{r}}=9,6: 1-W / h=0,25 ; 2-W / h=0,5 ;$

$$
3-W / h=1,0 ; 4-W / h=2,0 ; 5-W / h=5,0
$$

Fig. 3.4. Effective dielectric constant (a) and characteristic impedance (b) dependencies on frequency and conductor widths of coupled microstrip line operating in even mode, when $h=0.635 \mathrm{~mm}, W_{1} / h=W_{2} / h=W / h, S / h=1.0$, $\varepsilon_{\mathrm{r}}=9,6:$ Signal conductors widths are changed: $1-W / h=0.25$; $2-W / h=0.5 ; 3-W / h=1.0 ; 4-W / h=2.0 ; 5-W / h=5.0$

Skirtingų pločių laidininkų SML efektyviosios dielektrinès skvarbos skaičiavimo rezultatai, esant sinfaziniam ir priešfaziniamui sužadinimui, pateikti 3.6 paveiksle, a ir b atitinkamai. Būdingosios varžos skaičiavimai, esant SML sinfaziniam ir priešfaziniamui sužadinimui, pateikti 3.7 paveiksle, a ir b atitinkamai. Tiriant skirtingo pločio laidininkų SML buvo siekiama gauti abiejų laidininkų vienodą efektyviają dielektrinę skvarbą, nes tik tuo atveju linijose vyrauja normalių bangų režimas. Ittampos kiekvienam iš laidininkų sužadinti buvo apskaičiuotos naudojant momentų metodu grịstą SML modeli (Mikučionis, Urbanavičius 2011). 
Iš 3.6 paveikslo, a ir b kreivių pobūdžio matyti, kad efektyviosios dielektrinès skvarbos skirtumas tarp dviejų laidininkų nèra didelis ir sinfazinio sužadinimo atveju santykinis skirtumas neviršija $1 \%$, o priešfazinio sužadinimo atveju $3 \%$. Pastebètina, kad siauresnių signalinių laidininkų efektyviosios dielektrinès
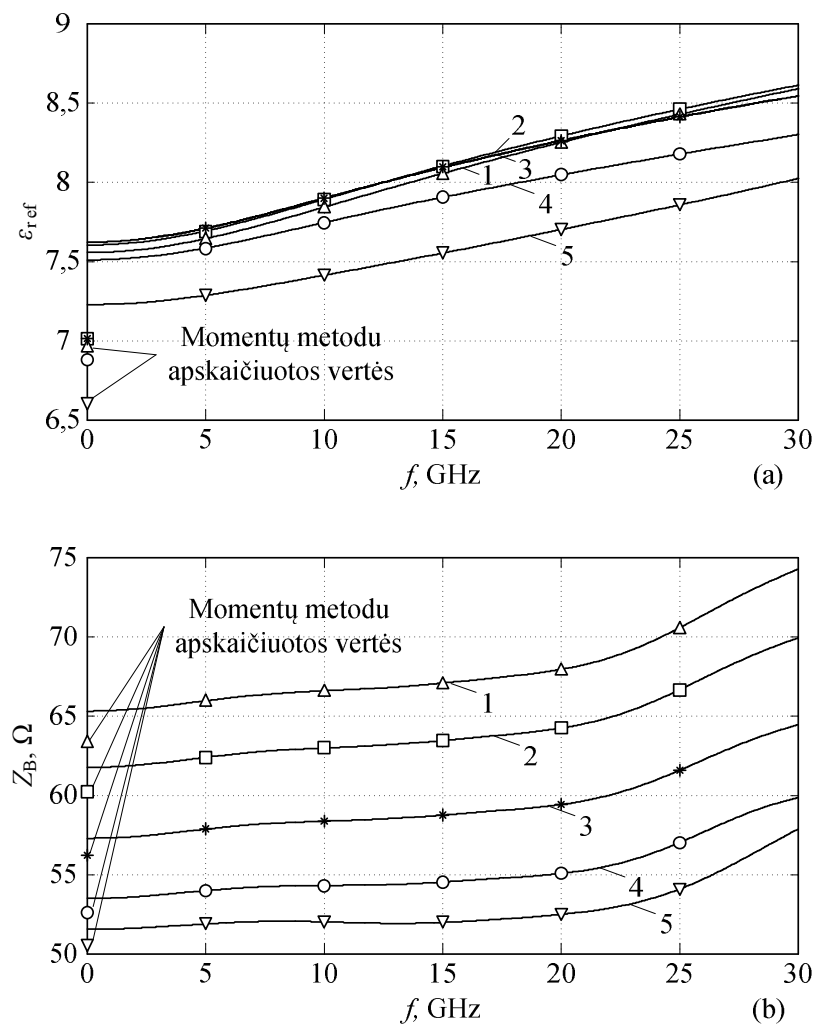

3.5 pav. Susietujų mikrojuostelinių linijų, veikiančių lyginių normaliujų bangų režimu, efektyviosios dielektrinès skvarbos (a) ir būdingosios varžos

(b) priklausomybès nuo dažnio ir tarpo tarp laidininkų dydžio, kai

$$
\begin{gathered}
W_{1} / h=W_{2} / h=W / h=1, h=0,635 \mathrm{~mm}, \varepsilon_{\mathrm{r}}=9,6: 1-S / h=0,25 ; \\
2-S / h=0,5 ; 3-S / h=1 ; 4-S / h=2 ; 5-S / h=5
\end{gathered}
$$

Fig. 3.5. Effective dielectric constant (a) and characteristic impedance (b) dependencies on frequency and space size between conductors of coupled microstrip lines operating on even mode, when $W_{1} / h=W_{2} / h=W / h=1$, $h=0.635 \mathrm{~mm}, \varepsilon_{\mathrm{r}}=9.6: 1-S / h=0.25 ; 2-S / h=0.5 ; 3-S / h=1$;

$$
4-S / h=2 ; 5-S / h=5
$$


skvarbos vertė didesnè nei platesnių laidininku žemuosiuose dažniuose, o aukštuosiuose (daugiau nei $20 \mathrm{GHz}$ ) - atvirkščiai. Šis kitimas panašus tiek sinfazinio tiek priešfazinio sužadinimo atvejais.

Lyginant žemuosiuose dažniuose apskaičiuotas efektyviosios dielektrinès skvarbos vertes ir momentų metodu gautas vertes, matyti, kad santykinis skirtumas neviršija $10 \%$, būdingosios varžos $-3 \%$.
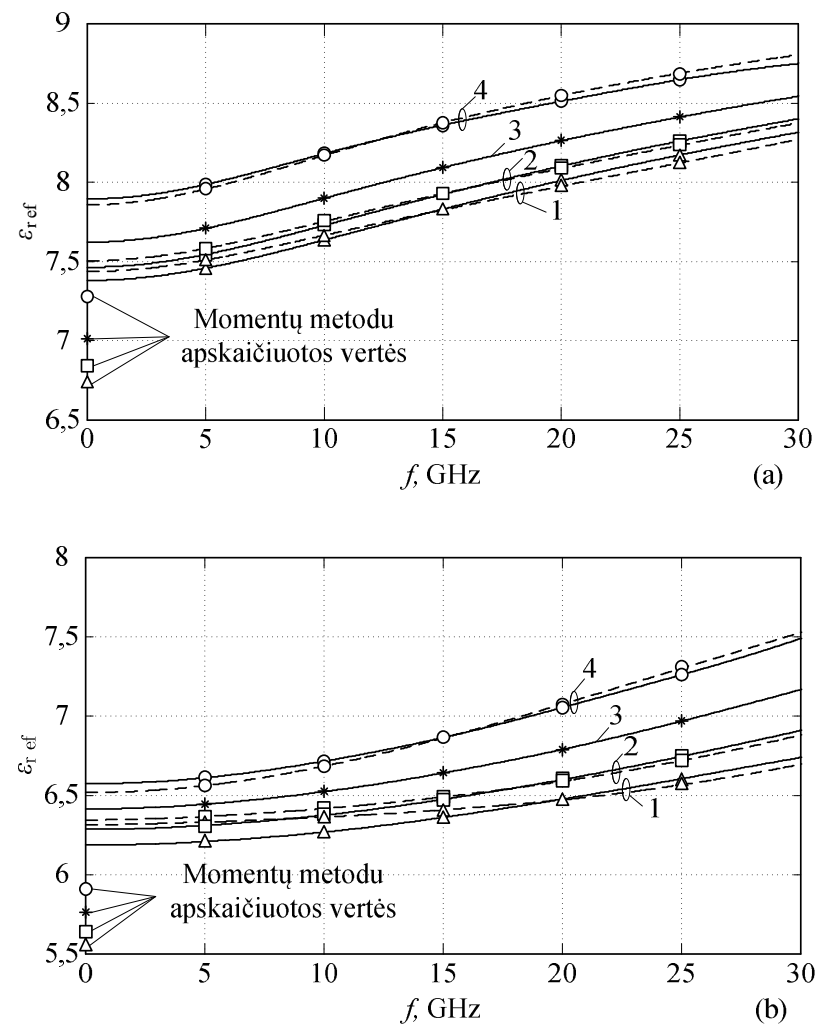

3.6 pav. Susietujų mikrojuostelinių linijų, sužadintų sinfaziškai (a) ir priešfaziškai (b), efektyviosios dielektrinès skvarbos priklausomybès nuo

dažnio ir laidininkų pločio santykių, kai $W_{1} / h=S / h=1, \varepsilon_{\mathrm{r}}=9,6$ :

$1-W_{2} / W_{1}=0,25 ; 2-W_{2} / W_{1}=0,5 ; 3-W_{2} / W_{1}=1 ; 4-W_{2} / W_{1}=2$.

Brūkšninėmis linijomis žymimos $\mathrm{W}_{2}$ laidininko priklausomybės, tiesiomis $-W_{1}$

Fig. 3.6. Coupled microstrip lines, operating in $\mathrm{c}$ and $\pi$ mode, effective dielectric constant dependencies on frequency and conductors width, when $W_{1} / h=S / h=1, \varepsilon_{\mathrm{r}}=9.6: 1-W_{2} / W_{1}=0.25 ; 2-W_{2} / W_{1}=0.5 ; 3-W_{2} / W_{1}=1$;

$4-W_{2} / W_{1}=2 . W_{2}$ values marked as dashed lines, $W_{1}$ as solid lines 

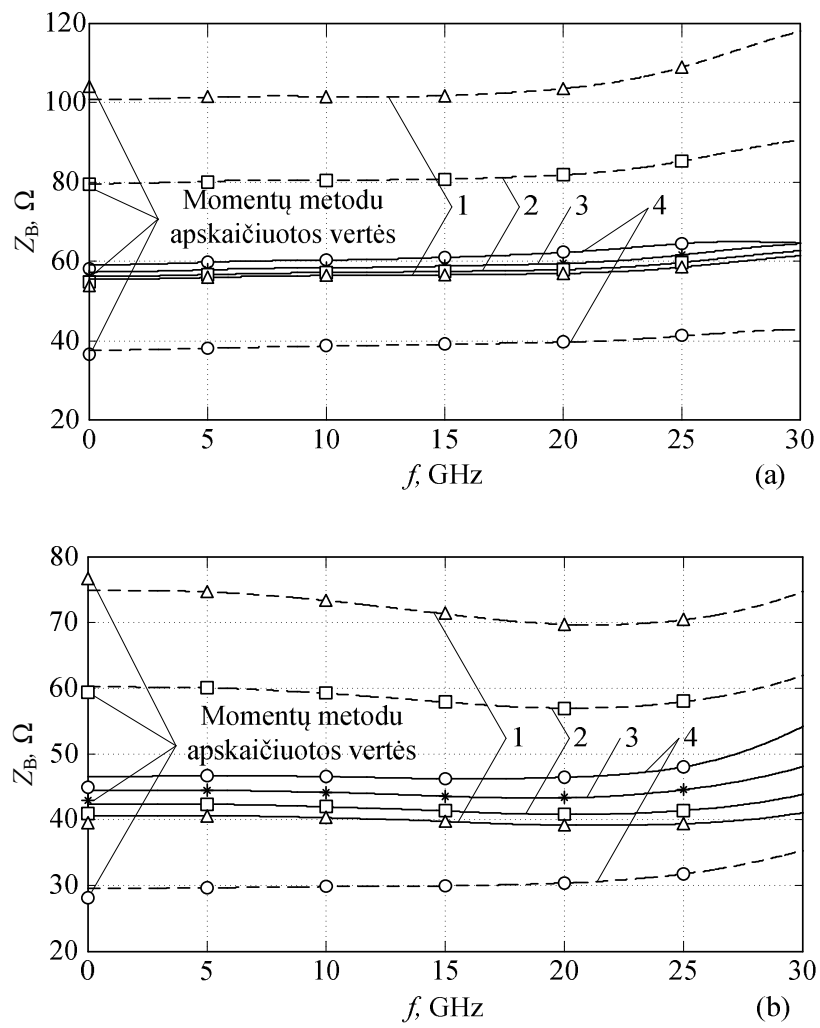

3.7 pav. Susietųu mikrojuostelinių linijų, sužadintų sinfaziškai (a) ir priešfaziškai (b), būdingosios varžos priklausomybès nuo dažnio ir laidininkų pločio santykių, kai $W_{1} / h=S / h=1, \varepsilon_{\mathrm{r}}=9,6: 1-W_{2} / W_{1}=0,25$; $2-W_{2} / W_{1}=0,5 ; 3-W_{2} / W_{1}=1 ; 4-W_{2} / W_{1}=2$. Brūkšninėmis linijomis žymimos $\mathrm{W}_{2}$ laidininko priklausomybès, tiesiomis $-W_{1}$

Fig. 3.7. Coupled microstrip lines, operating in $\mathrm{c}$ and $\pi$ mode, characteristic impedance dependencies on frequency and conductors width, when $W_{1} / h=S / h=1, \varepsilon_{\mathrm{r}}=9.6: 1-W_{2} / W_{1}=0.25 ; 2-W_{2} / W_{1}=0.5 ; 3-W_{2} / W_{1}=1$; $4-W_{2} / W_{1}=2$. $W_{2}$ values marked as dashed lines, $W_{1}$ as solid lines

Būdingosios varžos kitimo pobūdis, didejant dažniui (3.7 pav.), tiek vieno, tiek kito signalinio laidininko išlieka panašus, tačiau dèl skirtingų laidininkų pločių skiriasi jų būdingųjų varžų vertès. Kai SML antrasis laidininkas siauresnis už pirmajji laidininką, jo būdingoji varža didesnè ir atvirkščiai, kai pirmasis siauresnis - būdingoji varža mažesnè. Lyginant žemuosiuose dažniuose apskaičiuotas būdingosios varžos vertes ir momentų metodu gautas vertes, matyti, kad santykinis skirtumas neviršija $3 \%$, o efektyviosios dielektrinès skvarbos $-10 \%$. 
Iš konstrukcinių parametrų analizès matyti, kad visais atvejais, tiek esant nevienodiems signalinių laidininku pločiams, tiek tarpams tarp jų, efektyvioji dielektrinè skvarba, didèjant dažniui, didejja, dèl elektrinio lauko koncentracijos dielektriniame pagrinde. SML galima suderinti normaliujų bangų darbo režimui (sinfaziniam arba priešfaziniam), tačiau tokiu atveju skiriasi laidininkų būdingosios varžos.

\subsection{Daugialaidès mikrojuostelinès linijos modelis, grịstas baigtinių skirtumų laiko srities metodu}

Daugialaidès mikrojuostelinès linijos (DML) yra plačiai taikomos įvairiuose mikrobangu įtaisuose: filtruose, antenose, lètinimo sistemose ir vèlinimo įrenginiuose. Periodinès DML, sudarytos iš vienodo pločio signalinių laidininkų, elektromagnetinès bangos sklidimo greitis ties kiekvienu laidininku teoriškai yra vienodas, taip pat vienoda ir būdingoji varža. Ši prielaida leidžia idealiai suderinti DML su signalo šaltiniais bei apkrovomis. Tačiau realios DML gaminamos tik iš tam tikro skaičiaus laidininku - šios linijos neperiodinès ir jas sudarančių signalinių laidininkų elektriniai parametrai bendruoju atveju yra skirtingi.

Poskyryje aptariamas DML matematinis modelis grịstas baigtinių skirtumų laiko srities metodu, analizuojamos DML laikinès ir dažninès charakteristikos.

\subsubsection{Daugialaidès mikrojuostelinès linijos analizès algoritmas}

Daugialaidès mikrojuostelinès linijos sandaros eskizas pateiktas 3.8 paveiksle. Tokias linijas sudaro trys ir daugiau signalinių laidininkų, išdèstytų dielektrinio pagrindo paviršiuje, kurių plotis ir tarpas tarp jų gali skirtis.

Daugialaidès mikrojuostelinès linijos, grịstos baigtinių skirtumų laiko srities metodu, elektriniu parametru skaičiavimo algoritmas pateiktas 3.9 paveiksle. Algoritmą sudaro 14 žingsnių:

1. Ivedami analizuojamos daugialaidès mikrojuostelinès linijos konstrukciniai parametrai: $h$-dielektrinio pagrindo storis, $\varepsilon_{\mathrm{r}}$ - pagrindo dielektrinè skvarba; $l$ - signalinių laidininkų ilgis; $W_{1 \ldots N}-$ kiekvieno signalinio laidininko pločiai; $S_{1 \ldots N-1}-$ tarpų tarp signalinių laidininkų pločiai; $d$-absorbuojančio sluoksnio storis. Inicializuojamos elektrinès ir magnetinès indukcijos bei elektrinio ir magnetinio laukų stiprio matricos $[D],[B],[E]$ ir $[H]$ atitinkamai.

2. Inicializuojamos ir apskaičiuojamos vienaašio idealiai suderinto absorbuojančio sluoksnio koeficientų matricos. 


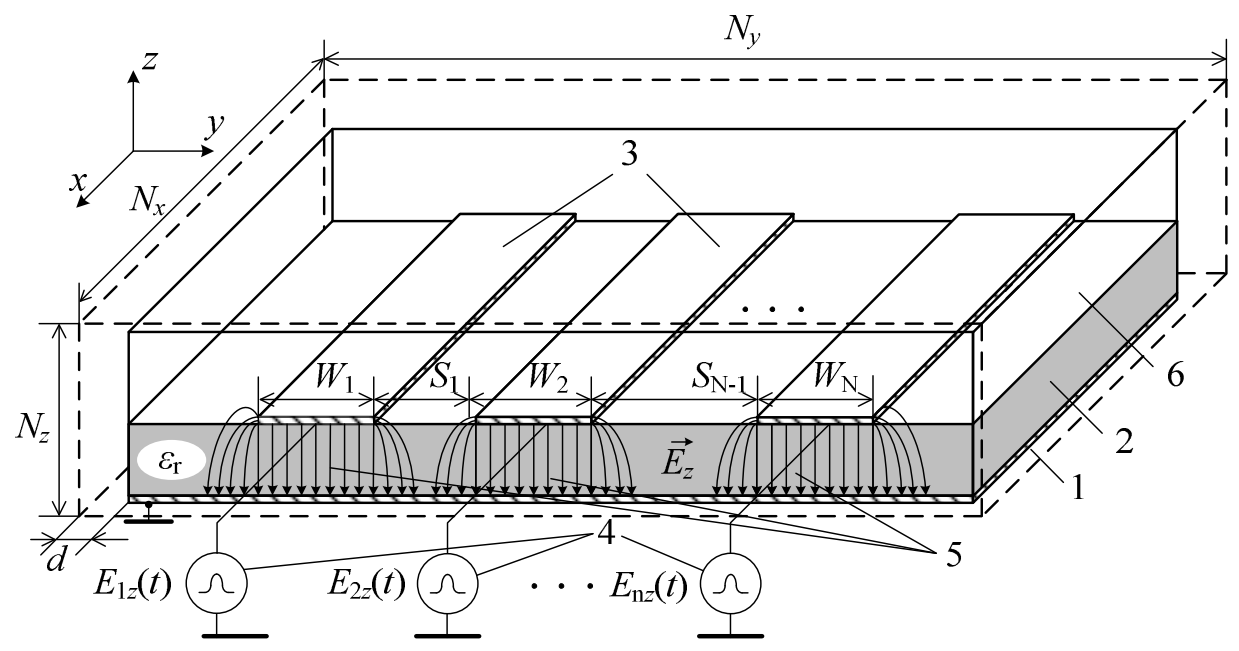

3.8 pav. Daugialaidès mikrojuostelinès linijos sandara: 1 - ekranas;

2 - dielektrinis pagrindas; 3 - signaliniai laidininkai; 4 - signalų šaltiniai;

5 - sužadinimo sritis (pažymèta tiesiomis, be šoninès sklaidos, elektrinio lauko stiprio jègos linijomis) skerspjūvyje; 6 - idealiai suderintas absorbuojantis sluoksnis

Fig. 3.8. Multiconductor microstrip structure for analysis: 1 - reference conductor; 2 - dielectric substrate; 3 - signal conductors; 4 - signal source;

5 - excitation area (marked as straight, without side spread, electric field lines) in cross section; 6 - perfectly matching layer

3. Inicializuojamos daugialaidès mikrojuostelinès linijos $E_{x}, E_{y}$ elektrinių ir $H_{z}$ magnetinio stiprio laukuose išsidèstymo koordinačių vektoriai atitinkamai $[d E x],[d E y]$. Šie išsidèstymo koordinačių vektoriai nurodo, kaip išsidèsčiusi DML nagrinejamoje srityje.

4. Apskaičiuojamos pirmojo DML laidininko, kurio plotis $W_{1}$ ir ilgis $l$ pozicija nagrinejjamoje srityje.

5. Pradedamas likusių laidininkų $W_{i}$ išsidėstymo koordinačių apskaičiavimo ciklas. Lyginama ar apskaičiuotas $i$-tasis signalinis laidininkas yra paskutinis DML. Ciklas baigiamas, kai apskaičiuojamos paskutinio $N$ tojo laidininko išsidèstymo koordinatès.

6. Analizuojamos DML išsidèstymo koordinačių apskaičiavimas pradedamas nuo antrojo $(i=2)$ signalinio laidininko išsidèstymo koordinačių elektriniuose $E_{x}, E_{y}$ ir magnetiniame $H_{z}$ laukuose, kai tarpas tarp prieš tai skaičiuoto signalinio laidininko ir skaičiuojamo yra $S_{i-1}$. 


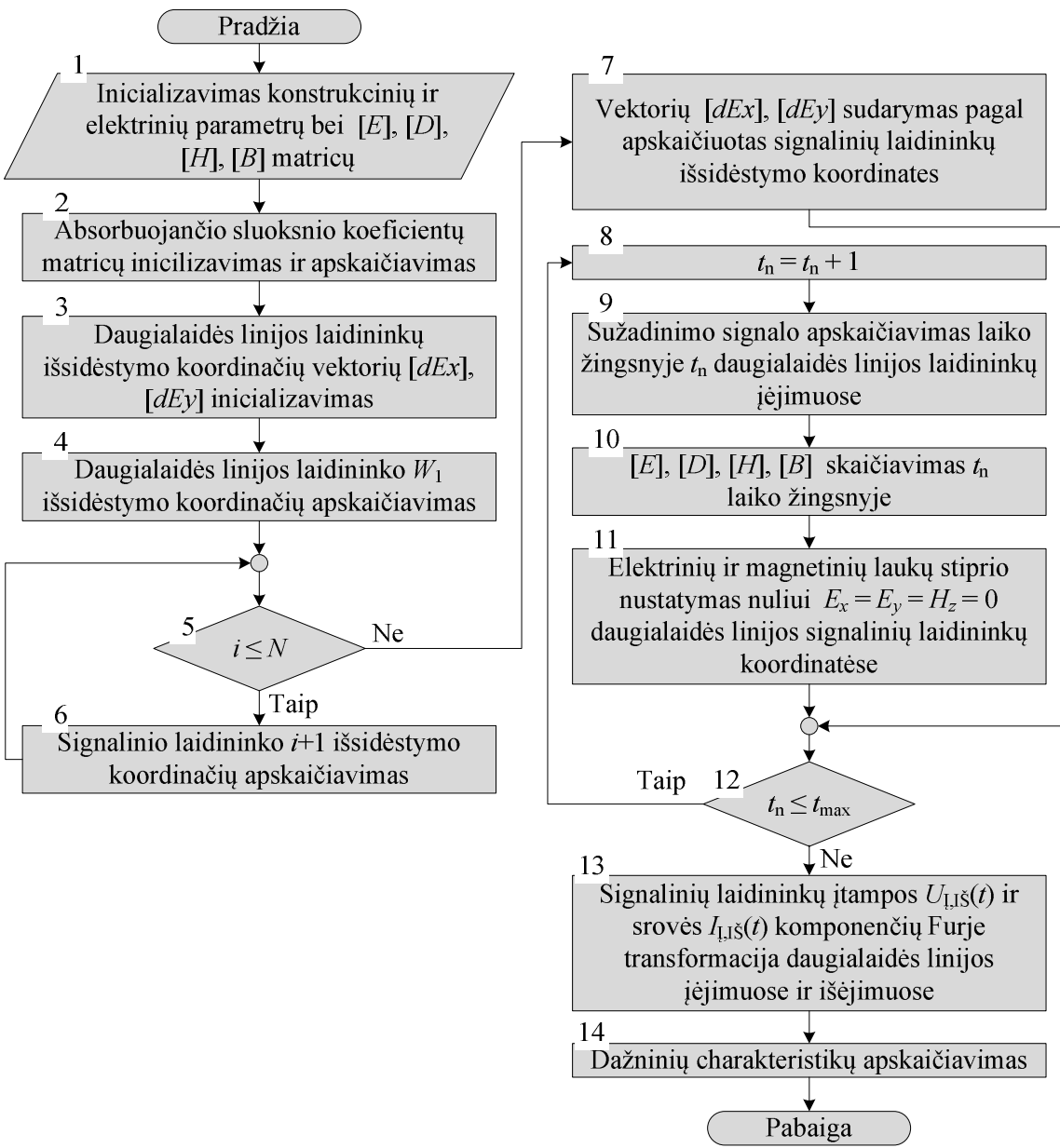

3.9 pav. Daugialaidès mikrojuostelinès linijos modelio, grịsto baigtinių skirtumų laiko srities metodu, supaprastintas algoritmas

Fig 3.9. The simplified algorithm of the multiconductor microstrip line model based on finite difference time domain method

7. Pagal apskaičiuotas DML signalinių laidininkų išsidèstymo koordinates sudaromos $[d E x],[d E y]$ koordinačių vektoriai. Siekiant modeliuoti suderintajji signalų šaltinị ir apkrovą, signalinių laidininkų iejjimai ir išèjimai tariamai pratęsiami ị absorbuojantị sluoksnị.

8. Skaičiavimų ciklas pradedamas, kai laiko žingsnis $t_{\mathrm{n}}$ lygus nuliui, kiekvieno sekančio ciklo metu laiko žingsnis inkrementuojamas vienetu.

9. Kiekvieno ciklo metu signalinių laidininkų ịejimuose perskaičiuojamas Gauso sužadinimo impulsas. Sužadinimas vykdomas nurodant atitinka- 
mo stiprio elektrini lauką dielektriniame pagrinde (3.8 pav.) per visą kiekvieno signalinio laidininko plotą.

10. Kiekviename analizès laiko žingsnyje $t_{\mathrm{n}}$ perskaičiuojamos elektrinès ir mangnetinès indukcijos bei laukų stiprių komponenčių matricos. Be to, tame pačiame laiko žingsnyje $t_{\mathrm{n}}$ apskaičiuojamos ir išsaugomos itampos ir srovès momentinès reikšmès DML įejime ir išèjime.

11. Kiekviename analizès laiko žingsnyje, atsižvelgus ị koordinačių vektorius $[d E x],[d E y]$, elektrinio ir magnetinio laukų stiprio komponentès $E_{x}, E_{y}$ ir $H_{z}$ prilyginamos nuliui, taip modeliuojant idealius signalinius laidininkus.

12. Pradedamas signalo sklidimo išilgai signalinio laidininko skaičiavimo ciklas. Skaičiavimo procesas šiuo atveju vykdomas tol, kol pasiekiamas didžiausias nurodytas analizès laiko žingsnis $t_{\text {max }}$.

13. Siekiant apskaičiuoti DML dažnines charakteristikas atliekama įtampos $U_{\text {t,Ĭ }}(t)$ ir srovès $I_{\mathrm{t}, \check{S}}(t)$ ièjime ir išèjime Furje transformacija.

14. Iš įtampos $U(\omega)$ ir srovès $I(\omega)$ santykio apskaičiuojama DML būdingoji varža, o iš ịtampos iejjime ir išejime santykio apskaičiuojama bangos sklidimo fazès koeficiento priklausomybè nuo dažnio $\beta(\omega)$. Iš bangos fazès koeficiento $\beta(\omega)$ apskaičiuojama efektinè dielektrinè skvarba $\varepsilon_{\mathrm{r}}(\omega)$.

\subsubsection{Daugialaidès mikrojuostelinès linijos modelio tyrimas}

Pasiūlytas daugialaidès mikrojuostelinès linijos modelis, grịstas baigtinių skirtumu laiko srities metodu, buvo tikrinamas dviem etapais. Pirma, tikrinamas matematinio modelio adekvatumas lyginant apskaičiuotas dispersines charakteristikas su (Liu et al. 2002) darbe skelbiamais rezultatais. Šiems skaičiavimams panaudota trijų laidininku daugialaide linija, kurios konstrukciniai parametrai yra šie: $h=0,635 \mathrm{~mm} ; W_{1}=0,3 \mathrm{~mm} ; S_{1}=0,2 \mathrm{~mm} ; W_{2}=0,6 \mathrm{~mm} ; S_{2}=0,4 \mathrm{~mm}$; $W_{3}=1,2 \mathrm{~mm}$; dielektrinio pagrindo skvarba $\varepsilon_{\mathrm{r}}=9,8$. Signalinių laidininkų sužadinimo itampos, skirtos sužadinti skirtingoms normaliosioms bangoms (modoms), gautos interpoliuojant (Liu et al. 2002) darbo rezultatus ir pateiktos 3.6 lenteleje. Antra, tiriama konstrukcinių parametru i itaka DML vèlinimo trukmès dažninèms priklausomybėms. Kiekvieno $k$-tojo DML signalinio laidininko 
tikslios vèlinimo trukmès $t_{\mathrm{dk}}$, esant žemiesiems dažniams, ir vèlinimo trukmès dažninès priklausomybès $t_{\mathrm{dk}}(f)$ apskaičiavimas yra svarbus, kai DML panaudojama signalų sinchronizavimui.

3.6 lentelè. İtampų, sąlygojančių normaliujų bangų (modų) sužadinimą trijų laidininkų linijoje, vertès, kai $\varepsilon_{\mathrm{r}}=9,6 ; h=0,635 \mathrm{~mm} ; S_{1}=0,2 \mathrm{~mm} ; S_{2}=0,4 \mathrm{~mm}$

Table 3.6. Values of voltages of three conductors for different normal wave excitation (modes), when $\varepsilon_{\mathrm{r}}=9.6 ; h=0.635 \mathrm{~mm} ; S_{1}=0.2 \mathrm{~mm} ; S_{2}=0.4 \mathrm{~mm}$

\begin{tabular}{|c|c|c|c|}
\hline \multirow{2}{*}{ Laidininko plotis, $\mathrm{mm}$} & \multicolumn{3}{|c|}{ Sužadinimo įtampos } \\
\cline { 2 - 4 } & $\begin{array}{c}\text { Priešfazinė } \\
\text { (A moda) }\end{array}$ & $\begin{array}{c}\text { Kombinuotoji } \\
\text { (B moda) }\end{array}$ & $\begin{array}{c}\text { Sinfazine } \\
\text { (C moda) }\end{array}$ \\
\hline$W_{1}=0,3$ & $1 \mathrm{~V}$ & $1 \mathrm{~V}$ & $1 \mathrm{~V}$ \\
\hline$W_{2}=0,6$ & $-0,876 \mathrm{~V}$ & $0,593 \mathrm{~V}$ & $1,180 \mathrm{~V}$ \\
\hline$W_{3}=1,2$ & $0,186 \mathrm{~V}$ & $-0,562 \mathrm{~V}$ & $1,081 \mathrm{~V}$ \\
\hline
\end{tabular}

Iš 3.10 paveikslo kreivių analizès matyti, kad efektyvioji dielektrinè skvarba, apskaičiuota pagal siūlomą modeli, skiriasi nuo apskaičiuotu ir paskelbtų (Liu et al. 2002) darbe ne daugiau kaip $10 \%$. Apskaičiuotose dažninèse priklausomybèse matyti, kad efektyviosios dielektrinès skvarbos santykinis skirtumas su (Liu et al. 2002) rezultatais yra didesnis viduriniuose dažniuose, iki $20 \mathrm{GHz}$ ruože (tačiau neviršija $10 \%$ ), ir mažesnis aukštesniuose dažniuose. Apskaičiuotos efektyviosios dielektrinès skvarbos santykinis skirtumas taip pat priklauso nuo sužadinimo modos. Kai visų laidininkų sužadinimo įtampos yra to paties ženklo santykinis skirtumas neviršija $3 \%$. Tačiau, kai sužadinimo įtampos yra skirtingo ženklo ir skirtumas tarp šių ịtampų verčių didesnis (A moda, tai vadintina priešfaziniu sužadinimu), efektyviosios dielektrinès skvarbos santykinis skirtumas su (Liu et al. 2002) darbe skelbiamais rezultatais išauga ir siekia $10 \%$. Taip pat pastebètina, kad esant idealiam tam tikros normaliosios bangos (modos) sužadinimui, efektyviosios dielektrinès skvarbos ties signaliniais laidininkais turi visiškai sutapti. Tačiau 3.10 paveikslo kreivès, žyminčios ties tam tikru laidininku apskaičiuotą efektyviaja skvarbą, nesutampa. Didžiausias nesutapimas pastebimas B modos atveju, siekiantis $3 \%$. Tai rodo, kad interpretuojant (Liu et al. 2002) darbo rezultatus nepavyko išvengti nuokrypių. 


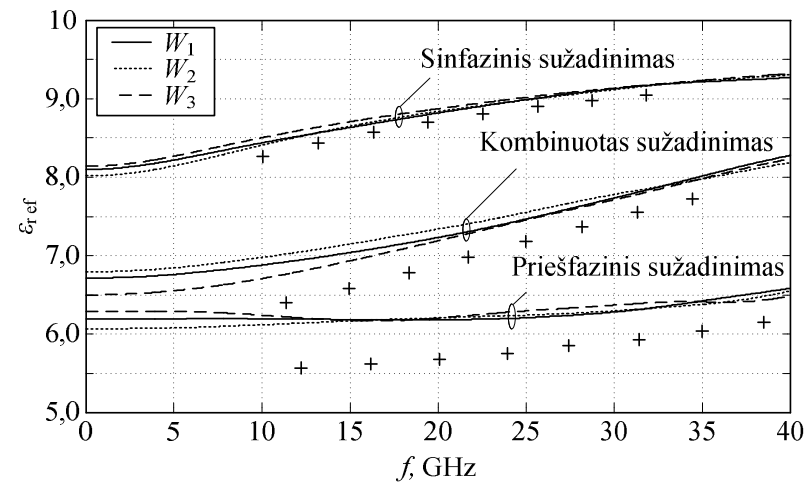

3.10 pav. Trijų laidininkų daugialaidès mikrojuostelinès linijos efektyviosios dielektrinès skvarbos priklausomybės nuo dažnio ir sužadinimo modos. Kryžiukais sužymèti (Liu et al. 2002) darbe gauti rezultatai

Fig. 3.10. Effective permittivity of three conductors multiconductor microstrip line dependencies on frequency and on mode. Values calculated by (Liu et al. 2002) work marked as crosses

Dispersijos ir sąryšio efektai DML yra pagrindinès priežastys įtakojančios šiose linijose sklindančius signalus. Dèl šių faktorių sumažeja sklindančių signalų amplitude ir išsiplečia signalų forma laike. Laikinių parametrų skaičiavimams panaudota šešių laidininkų daugialaidè linija, kurios konstrukciniai parametrai yra šie: $h=0,635 \mathrm{~mm} ; W_{1-6}=0,6 \mathrm{~mm} ; S_{1-5}$ kinta nuo $0,6 \mathrm{~mm}$ iki $1,8 \mathrm{~mm}$, $0,6 \mathrm{~mm}$ žingsniu; dielektrinio pagrindo skvarba $\varepsilon_{\mathrm{r}}=9,8$; signalinių laidininkų ilgis $L=30 \mathrm{~mm}$.

Kiekvieno laidininko vèlinimo trukmès priklausomybė nuo dažnio gali būti apskaičiuojama naudojant išraišką:

$$
t_{\mathrm{d} k}(f)=\frac{L \sqrt{\varepsilon_{\mathrm{ref} k}(f)}}{c_{0}},
$$

čia $L$ - atstumas tarp laidininko įèjimo ir išèjimo signalų; $\varepsilon_{\text {ref } k}(f)-k$-ojo signalinio laidininko efektyviosios dielektrinès skvarbos dažninè charakteristika.

Kiekvieno signalinio laidininko vèlinimo trukmè apskaičiuota kylančio fronto viduryje tarp iejjimo ir išejimo signalų pateikta 3.11 paveiksle. Kadangi DML konstrukcija simetriška (t. y. pirmo ir šešto, antro ir penkto, trečio ir ketvirto laidininko elektriniai parametrai sutampa), analizuojama tik puse linijos laidininkų. Kiekvienas signalinis laidininkas įprastinio sužadinimo atveju sužadinamas tos pačios amplitudès Gauso impulsu. 


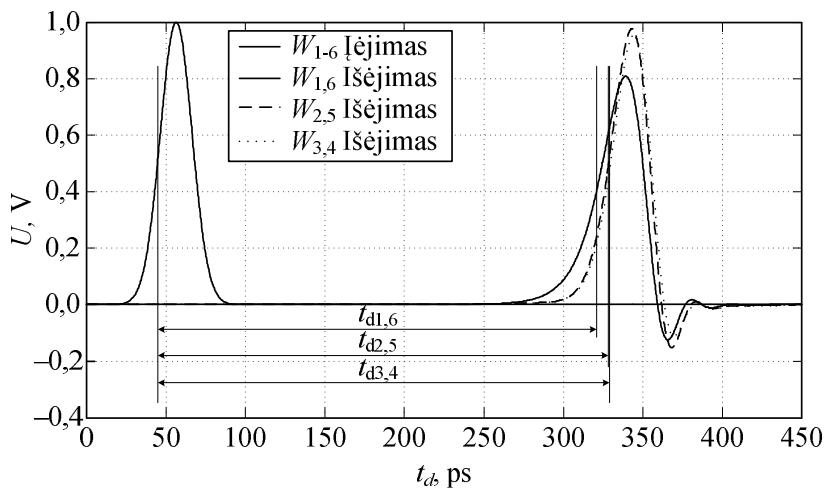

3.11 pav. Šešių laidininkų daugialaidès mikrojuostelinès linijos ịejimo ir išẻjimo signalų kitimas laike bei jų vèlinimo priklausomybès nuo laidininko pozicijos, kai tarpas tarp laidininkų $\mathrm{S}_{1-5}=1,8 \mathrm{~mm} ; \varepsilon_{\mathrm{r}}=9,8 ; h=0,635 \mathrm{~mm}$;

$$
W_{1-6}=0,6 \mathrm{~mm}
$$

Fig. 3.11. Input and output signals of 6-conductors multiconductor microstrip line and their time delay dependencies on conductor number, when space between them $\mathrm{S}_{1-5}=1.8 \mathrm{~mm} ; \varepsilon_{\mathrm{r}}=9.8 ; h=0.635 \mathrm{~mm}$;

$$
W_{1-6}=0.6 \mathrm{~mm}
$$

Dèl dispersijos ir sąryšio efekto kiekvieno signalinio laidininko vèlinimo trukmè yra skirtinga (3.11 pav.) ir priklauso nuo tarpo tarp signalinių laidininkų (3.7 lentelè). Didžiausias vèlinimo trukmès skirtumas analizuojamoje DML pastebimas tarp vidinių ir išorinių signalinių laidininkų. Modeliuojamos DML šis skirtumas sudaro $6,2 \%$, kai tarpas tarp laidininku yra 0,6 mm. Didinant tarpą tarp signalinių laidininkų, sąryšio efektas tarp laidininkų mažeja ir, kai tarpas tarp jų yra $1,8 \mathrm{~mm}$, skirtumas tarp išorinių ir vidinių laidininkų vélinimo laiko tesudaro tik $2,8 \%$.

Sąryšio efektas tarp signaliniu laidininku išryškèja, kai DML sužadinamas tik vienas laidininkas (3.12 pav.). Iš paveiksle pateiktų kreivių matyti, kad DML signalinio laidininko $W_{1}$ iejjime sužadinus Gauso impulsą, impulsai taip pat susižadina ir $W_{2}$ bei $W_{3}$ laidininkuose. Linijoje sklindant signalui, dèl laidininkų tarpusavio sąryšio efekto įtampos impulsai atsiranda ir kituose laidininkuose. DML išèjime $W_{2-6}$ laidininkuose susižadinusios įtampos dydis priklauso nuo atstumo nuo $W_{1}$ laidininko ir nuo signalo nueito atstumo.

$N$ laidininkų daugialaidès mikrojuostelinès linijos gali dirbti $N$ skirtingais normaliujų bangų darbo rěžimais (sužadinimo modomis). Nagrinejjamu šešių laidininkų DML atveju buvo tiriami tik trys skirtingi darbo réžimai (3.13 pav.): iprastinis (kai visi signaliniai laidininkai sužadinami tos pačios amplitudès (1 V) Gauso impulsai), sinfazinis bei priešfazinis. Sinfazinio sužadinimo atveju 


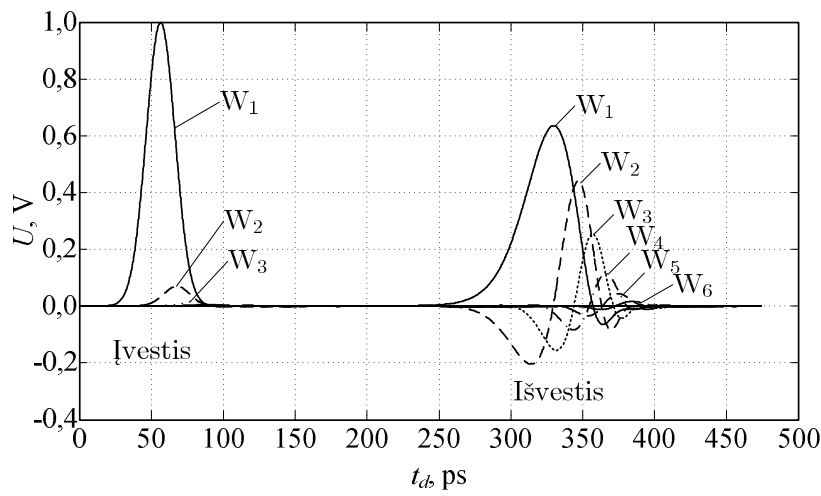

3.12 pav. Šešių laidininkų daugialaidès mikrojuostelinès linijos ịjjimo ir išèjimo signalai ir jų priklausomybès nuo laidininko pozicijos, kai signalas sužadinamas tik $W_{1}$ laidininke ir tarpas tarp laidininkų $\mathrm{S}_{1-5}=1,8 \mathrm{~mm}$;

$$
\varepsilon_{\mathrm{r}}=9,8 ; h=0,635 \mathrm{~mm} ; W_{1-6}=0,6 \mathrm{~mm}
$$

Fig. 3.12. Input and output signals of 6-conductors multiconductor microstrip line and their time dependencies on conductor number, when excited only $W_{1}$ conductor and space between conductors $\mathrm{S}_{1-5}=1.8 \mathrm{~mm}$;

$$
\varepsilon_{\mathrm{r}}=9.8 ; h=0.635 \mathrm{~mm} ; W_{1-6}=0.6 \mathrm{~mm}
$$

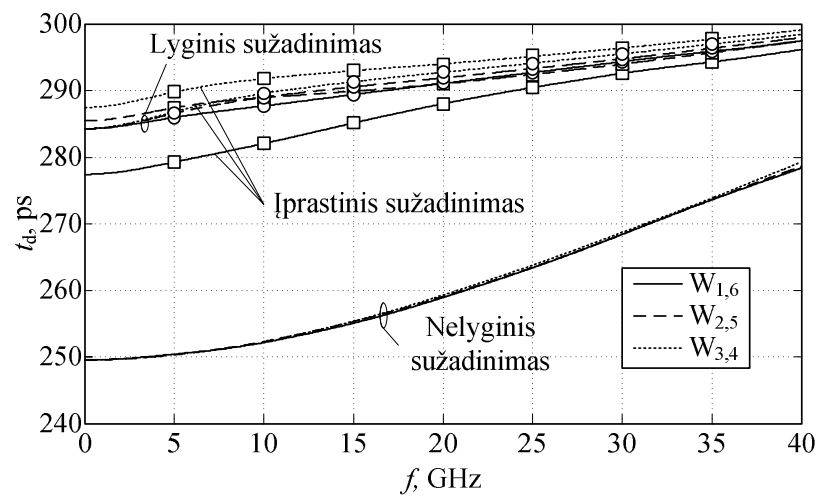

3.13 pav. Šešių signalinių laidininkų daugialaidès mikrojuostelinès linijos, veikiančios normaliujų ir mišriujų bangų darbo rěžimais, vèlinimo trukmès priklausomybės nuo dažnio, kai $\mathrm{S}_{1-5}=1,8 \mathrm{~mm} ; \varepsilon_{\mathrm{r}}=9,8 ; h=0,635 \mathrm{~mm}$;

$$
W_{1-6}=0,6 \mathrm{~mm}
$$

Fig. 3.13. Time delay dependencies on frequency of six conductors multiconductor microstrip line, operated in normal and mixed wave mode, when $\mathrm{S}_{1-5}=1.8 \mathrm{~mm} ; \varepsilon_{\mathrm{r}}=9.8 ; h=0.635 \mathrm{~mm} ; W_{1-6}=0.6 \mathrm{~mm}$ 
kiekvieno laidininko Gauso impulsų amplitudžių vertès nustatytos: $U_{1,6}=$ $0,608 \mathrm{~V} ; U_{2,5}=0,869 \mathrm{~V} ; U_{3,4}=1 \mathrm{~V}$. Priešfazinio sužadinimo atveju kiekvieno laidininko Gauso impulsų amplitudžių vertès nustatytos: $U_{1,6}=\mp 0,373 \mathrm{~V} ; U_{2,5}=$ $\pm 0,7784 \mathrm{~V} ; U_{3,4}=\mp 1 \mathrm{~V}$. Sinfazinio ir priešfazinio sužadinimo amplitudžių itampos apskaičiuotos naudojant momentų metodą ir tikrinès vertès radimo būdą. Analizuojant 3.13 paveiksle pateiktas kreives matyti, kad signalų, sklindančių ties DML laidininkais, vèlinimo trukmès dažninių priklausomybių skirtumai yra minimalūs, kai linija dirba sinfazinès arba priešfazinès normaliosios bangos režimu.

Padaryta prielaida, kad nagrinejjamos DML konstrukcinès medžiagos yra idealios, taigi ji yra tiesinis įtaisas be nuostoliu, todèl joje vyrauja faziniai iškraipymai ir jos praleidžiamujų dažnių ruožas nustatomas iš DFCh, t. y. apskaičiuo-

3.7 lentelè. Signalinių laidininkų vẻlinimo trukmių apskaičiuotos vertės, esant ịvairiems tarpams tarp laidininku, kai $\varepsilon_{\mathrm{r}}=9,8 ; h=0,635 \mathrm{~mm} ; W_{1-6}=0,6 \mathrm{~mm}$

Table 3.7. Delay time calculation from time domain characteristics with different spaces, when $\varepsilon_{\mathrm{r}}=9.8 ; h=0.635 \mathrm{~mm} ; W_{1-6}=0.6 \mathrm{~mm}$

\begin{tabular}{|c|c|c|c|}
\hline \multirow{2}{*}{ Laidininko numeris } & \multicolumn{3}{|c|}{ Vèlinimo trukmé, ps } \\
\cline { 2 - 4 } & $S=0,6 \mathrm{~mm}$ & $S=1,2 \mathrm{~mm}$ & $S=1,8 \mathrm{~mm}$ \\
\hline$t_{\mathrm{d} 1,6}$ & 283,2 & 278,8 & 276,1 \\
\hline$t_{\mathrm{d} 2,5}$ & 298,4 & 289,7 & 283,4 \\
\hline$t_{\mathrm{d} 3,4}$ & 301,9 & 293,7 & 284,3 \\
\hline
\end{tabular}

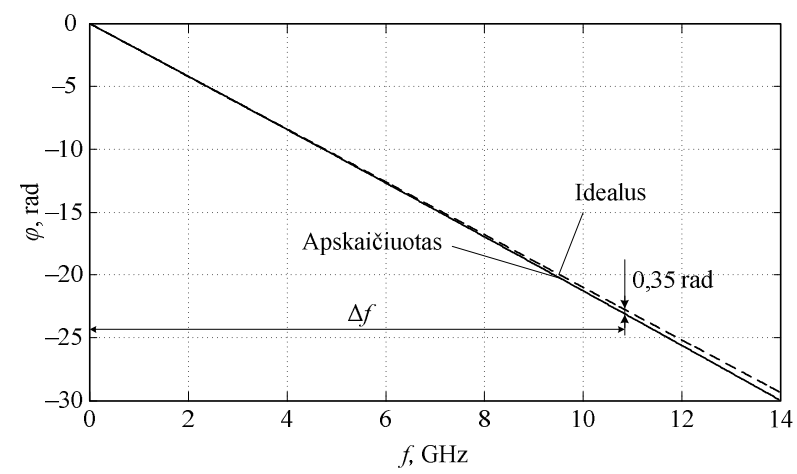

3.14 pav. Šešių laidininkų mikrojuostelinès linijos pralaidumo juostos nustatymas, kai $\varepsilon_{\mathrm{r}}=9,6 ; h=0,635 \mathrm{~mm} ; \mathrm{S}_{1-5}=1,8 \mathrm{~mm} ; W_{1-6}=0,6 \mathrm{~mm}$

Fig. 3.14. Bandwidth calculation of six conducotrs multiconductor microstrip line, when $\varepsilon_{\mathrm{r}}=9.6 ; h=0.635 \mathrm{~mm} ; \mathrm{S}_{1-5}=1.8 \mathrm{~mm} ; W_{1-6}=0.6 \mathrm{~mm}$ 
jamas idealių ir realių fazinių dažninių charakteristikų skirtumas. Idealios DFCh atveju DML išejime signalo forma tokia pati kaip ir iejjime, tik šis signalas pastumtas per vèlinimo trukmę, kuri randama panaudojant apskaičiuotą kiekvieno laidininko efektyviąą dielektrinę skvarbą, įstatant ją i (3.10) išraišką. Kadangi DML išorinių laidininkų signalai išèjime labiau iškraipyti nei vidinių laidininkų, t. y. išorinių signalinių laidininkų praleidžiamų dažnių juosta siauresnè, todèl šie laidininkai ir pasirenkami siekiant nustatyti DML praleidžiamųjų dažnių juostą. Nagrinejjamos DML išorinių laidininkų idealiosios ir realiosios DFCh pateiktos 3.14 paveiksle.

Paveiksle matyti, kad 0,35 rad skirtumas tarp idealios ir realios DFCh susidaro ties $10,75 \mathrm{GHz}$, taigi, teigtina, kad šios daugialaidès linijos praleidžiamujuc dažnių juosta taip pat siekia $10,75 \mathrm{GHz}$.

\subsection{Daugialaidès mikrojuostelinès linijos konstrukciniụ parametrụ sintezès algoritmai}

Meandrinès mikrojuostelinès vèlinimo linijos (MMVL) modeliavimui, dèl jos periodinès struktūros, plačiai taikomas daugialaidžių linijų metodas (Daškevičius et al. 2010). Siekiant gauti norimų elektrinių parametrų MMVL, sprendžiama sintezès problema. Sintezès problemos aktualios, siekiant automatizuoti mikrobangu įtaisų projektavimo darbus. Daugelis tyrejų visame pasaulyje sprende sintezès problemas, pvz., (Rawat, Ghannouchi 2009) darbe pateikiamos matematinès išraiškos, siejančios projektuojamo įtaiso elektrines charakteristikas ir šio itaiso konstrukcinius parametrus. (Hong-Ming, Chih-Ming 2009) darbe pateikiamos matematinès išraiškos, leidžiančios nustatyti trijų laidininkų DML elektrines charakteristikas pagal ekvivalentinès schemos parametrus. (Mikučionis, Urbanavičius 2010) darbe pateikiamos keturių laidininkų DML, veikiančios normaliujų bangų režimu, sintezès metodika.

Poskyryje pateikiamos tolygios ir netolygios būdingosios varžos daugialaidès mikrojuostelinès linijos konstrukcinių parametrų sintezès algoritmai, grịsti baigtinių skirtumų metodu.

\subsubsection{Konstrukcinių parametrų sintezès algoritmas}

Sintezuojant elektronini ịtaisą tenka daug kartų vykdyti šio įtaiso matematinio modelio analizę. Siekiant sumažinti projektavimo trukmę, taikytini ekstremumo paieškos metodai (Pomarnacki 2010), skiltinio artèjimo (Neapolitan, Naimipour 2004) arba uždavinį išskaidant lygiagrečioje kompiuterizuotoje sistemoje.

Siekiant sudaryti DML, kurią sudaro didelis skaičius $(N>10)$ signalinių laidininkų, analizuojamos srities dydis, kuris proporcingas laidininkų skaičiui, 
gali smarkiai padidèti. Tačiau, jeigu DML sudaryta iš vienodo pločio signalinių laidininkų ir lygių tarpų tarp jų, DML modelyje galima ịvertinti linijos periodiškumą ir simetriją nagrinèjant tik mažają DML dalį, kuri 3.15 paveiksle parodyta tarp 6,8 bei 7,8 plokštumų.

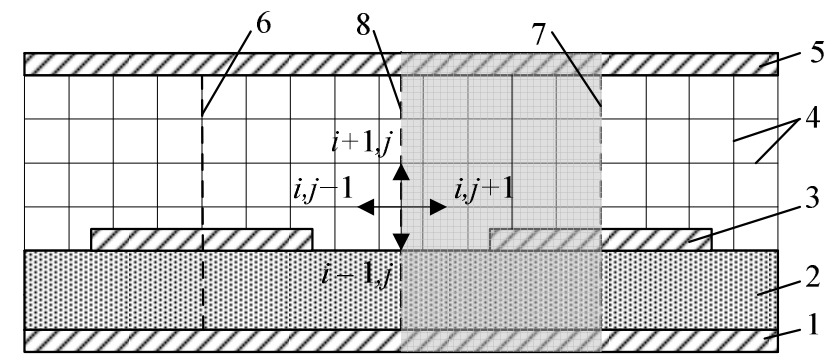

3.15 pav. Daugialaidès mikrojuostelinès linijos su periodinėmis plokštumomis modelis (analizuojama sritis patamsinta): 1 - apatinis

ekranas; 2 - dielektrinis pagrindas; 3 - signalinis laidininkas; 4 - analizuojamos srities gardelè; 5 - viršutinis ekranas; 6, 7 - signalinių laidininkų periodiškumą įvertinančios, atitinkamai, kairioji ir dešinioji plokštumos; 8 - tarpų tarp signalinių laidininkų periodiškumą ịvertinanti plokštuma

Fig. 3.15. The model of the multiconductor microstrip lines with symmetric areas (area of analysis is shaded): 1 - bottom reference conductor; 2 - dielectric substrate; 3 - microstrips; 4 - grid of the area of analyses; 5 - upper reference conductor; 6,7 - planes where microstrips conductors are symmetric; 8 - plane where space between microstrips conductors is symmetric

Atsižvelgus i DML simetriškumą ties 3.15 paveikslo pateiktomis 6,7 ir 8 plokštumomis, baigtinių skirtumų metodo potencialų skaičiavimo lygtis (2.2) turi būti pakeista (Štaras 2008). Šiuo atveju (2.2) lygtis ties 3.15 paveikslo 7 ir 8 plokštumomis atitinkamai tampa:

$$
\begin{aligned}
& \varphi(i, j)=\frac{1}{4}[2 \varphi(i+1, j)+\varphi(i, j+1)+\varphi(i, j-1)], \\
& \varphi(i, j)=\frac{1}{4}[2 \varphi(i-1, j)+\varphi(i, j+1)+\varphi(i, j-1)],
\end{aligned}
$$

čia $\varphi$ - elektrinio lauko potencialas; $i, j$ - indeksai nurodantys ieškomo potencialo poziciją dvimateje srityje.

(3.11) ir (3.12) lygtimis įvertinamas analizuojamos DML periodiškumas ir sumažinamas analizuojamos srities dydis, o tai savo ruožtu paspartina skaičiavimus. 
Remiantis šiuo modeliu sudarytas DML konstrukcinių parametru sintezès algoritmas (3.16 pav.), grịstas baigtinių skirtumų ir skiltinio artejimo metodais, kuris, pagal nurodyta būdingosios varžos vertę ir nuokrypi nuo jos, sintezuoja tam tikrų konstrukcinių parametrų DML. Sintezès metu randami šie konstrukciniai parametrai: dielektrinio pagrindo storis $h$; santykinè dielektrinè skvarba $\varepsilon_{\mathrm{r}}$, laidininkų pločiai $W$ ir tarpai tarp jų $S$. Algoritmą sudaro 20 žingsnių:

1. İvedami daugialaidès mikrojuostelinès linijos konstrukciniai parametrai: $h_{\min }$ ir $h_{\max }-$ minimalus ir maksimalus dielektrinio pagrindo storis; $\varepsilon_{\mathrm{r} \min }$ ir $\varepsilon_{\mathrm{r} \max }-$ minimali ir maksimali pagrindo dielektrinè skvarba; $W_{\min }$ ir $W_{\max }-$ minimalus ir maksimalus signalinio laidininko plotis; $S_{\min }$ ir $S_{\max }$ - minimalaus ir maksimalaus tarpo tarp signalinių laidininkų plotis; $Z_{\text {Bnom }}$ - nominali (norima) būdingosios varžos vertė; $\delta$ - leistinas būdingosios varžos nuokrypis.

2. Iš pateiktų konstrukcinių parametrų minimalių ir maksimalių verčių apskaičiuojami vidurkiai bei atliekama konstrukcijos pirminė analizė - apskaičiuojama būdingoji varža.

3. Pradedami skiltinio artejjimo ciklai ir pirma patikrinama ar dielektrinès skvarbos ribos nėra viršytos. Jeigu ribos viršytos, nutraukiamas darbas ir pereinama i 20 žingsnị, kuriame pateikiama, kad tokiose ribose neįmanoma rasti norimos būdingosios varžos vertès DML.

4. Patikrinama ar tarpų tarp signalinių laidininkų pločio ribos nèra viršytos. Jei ribos neviršytos pereinama ị 5 žingsni, jei viršytos - i 16 žingsnị.

5. Patikrinama ar signalinių laidininkų pločių ribos nèra viršytos. Jei ribos neviršytos pereinama ị 6 žingsni, jei viršytos - i 12 žingsnį.

6. 12. 16. Žingsniuose apskaičiuojamos vidutinès signalinių laidininkų pločio $W_{\text {vid, }}$ tarpo tarp jų $S_{\text {vid }}$ ir dielektrinès skvarbos $\varepsilon_{\mathrm{r} \text { vid }}$ reikšmès tarp nustatytų minimalių ir maksimalių verčių.

7. Apskaičiuojama būdingosios varžos vertè, esant vidutinei laidininkų pločių, tarpo pločių tarp laidininkų ir dielektrinès skvarbos vertei.

8. 13. 17. Žingsniuose atliekamas palyginimas ar apskaičiuota būdingoji varža didesnè ar mažesnè už nominalią būdingosios varžos vertę.

9. 14. 18. Žingsniuose atliekamas signalinių laidininkų pločio, tarpo pločio tarp laidininkų ir dielektrinès skvarbos koregavimas. Jei apskaičiuota būdingosios varžos verte mažesnè už nominalią, nustatoma atitinkamo parametro nauja maksimali galima riba (maksimali riba prilyginama prieš tai apskaičiuotai vidutinei $W_{\text {vid, }} S_{\text {vid }}$ arba $\varepsilon_{\text {r vid }}$ vertei). 


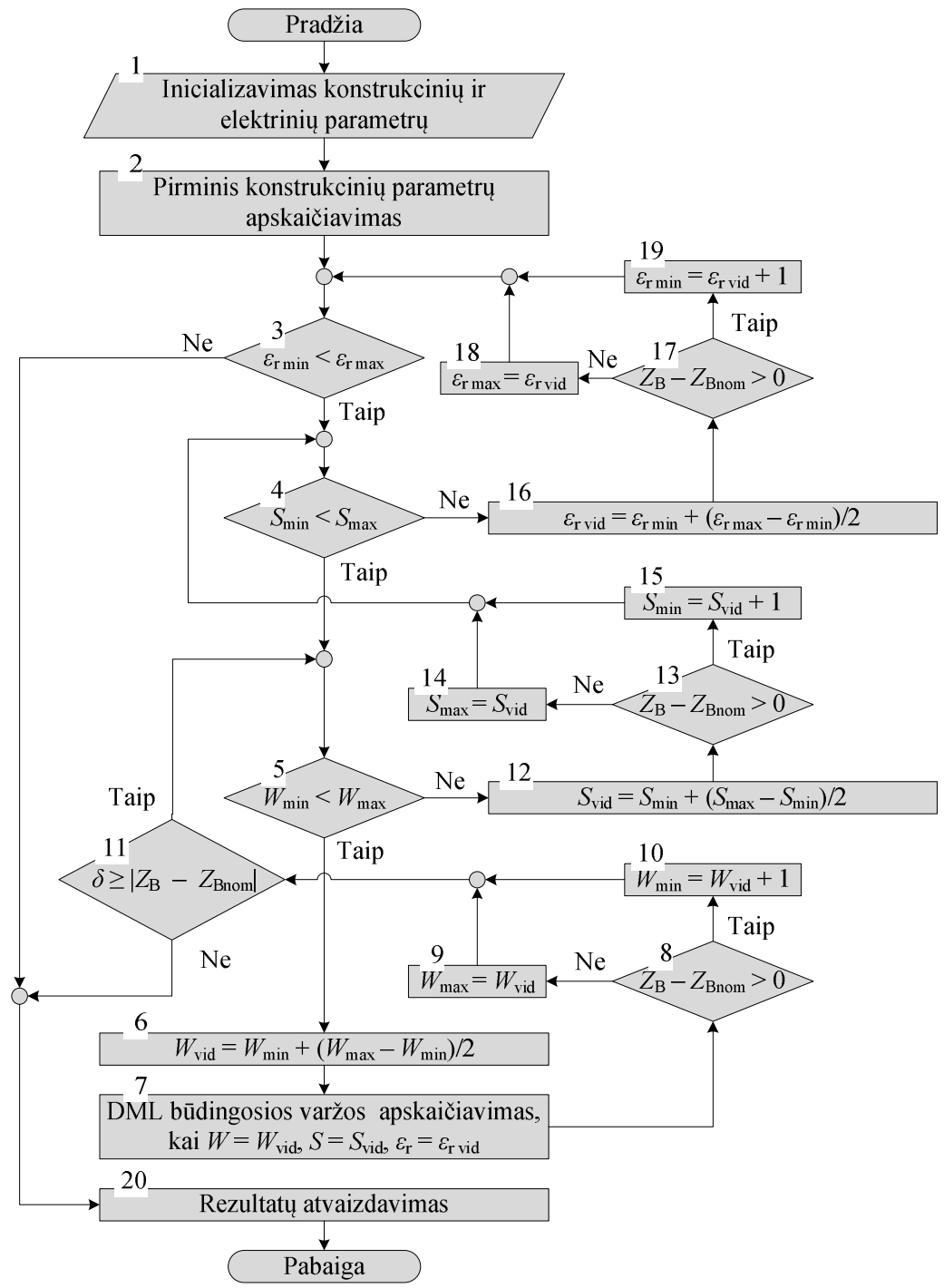

3.16 pav. Daugialaidès mikrojuostelinès linijos konstrukcinių parametrų sintezès, grịstos baigtinių skirtumų metodu, supaprastintas algoritmas

Fig 3.16. The simplified synthesis algorithm of the multiconductor microstrip line structural parameters, based on finite difference method

10. 15. 19. Žingsniuose atliekamas signalinių laidininkų pločio, tarpo pločio tarp laidininkų ir dielektrinès skvarbos koregavimas. Jei apskaičiuota būdingosios varžos vertè mažesnè už nominalią, nustatoma atitinkamo 
parametro nauja minimali galima riba (minimali riba prilyginama prieš tai apskaičiuotai vidutinei $W_{\text {vid }}, S_{\text {vid }}$ arba $\varepsilon_{\text {r vid }}$ vertei).

11. Atliekamas palyginimas ar apskaičiuotos ir nominalios būdingosios varžos absoliutus skirtumas neviršija leistino būdingosios varžos nuokrypio $\delta$. Jei nuokrypio neviršija, pereinama ị 20 žingsni, kitu atveju vèl pereinama ị 5 žingsnị.

20. Atvaizduojami rezultatai su nustatytais konstrukciniais parametrais ir gauta būdingaja varža, esant tiems patiems konstrukciniams parametrams. Jei nepavyksta rasti konstrukcinių parametrų tam tikrai būdingajai varžai - parodomas atitinkamas pranešimas.

Sudarytas DML konstrukcinių parametrų radimo pagal nurodytą nominalią būdingosios varžos vertę algoritmas leidžia greitai surasti norimus konstrukcinius parametrus. Tačiau, realiai gaminamų MMVL, sudarytų pagal DML konstrukcinius parametrus, strypų skaičius yra baigtinis ir skiriasi šoninių strypų būdingujų varžų charakteristikos. Naudojant periodinès DML sintezės algoritmą, galima sudaryti tam tikro strypu skaičiaus MMVL, tačiau bus neįvertinti šoninių laidininkų elektriniai parametrai.

\subsubsection{Tolygios būdingosios varžos sintezès algoritmas}

Siekiant įvertinti MMVL, sudarytos pagal DML konstrukcinius parametrus, šoninių strypų būdingosios varžos įtaką ir suvienodinti ją visoje MMVL, sudaromas tolygios būdingosios varžos DML konstrukcinių parametrų sintezės algoritmas.

Daugialaidès mikrojuostelinès linijos, grịstos baigtinių skirtumų metodu, konstrukciniu parametru pagal nurodytą (nominalią) būdingosios varžos vertę sintezès algoritmas pateiktas 3.17 paveiksle. Algoritmą sudaro 11 žingsnių:

1. İvedami daugialaidès mikrojuostelinès linijos pradiniai konstrukciniai parametrai: $h$-dielektrinio pagrindo storis; $\varepsilon_{\mathrm{r}}$ - pagrindo dielektrinè skvarba; $W$ - signalinio laidininko plotis; $S$ - tarpo tarp signalinių laidininkų plotis; $Z_{\text {Bnom }}$ - nominali (norima) būdingosios varžos verte;; $\delta$ - leistinas būdingosios varžos nuokrypis; $N$ - laidininkų skaičius; $m$ - sužadinimo būdas (sinfazinis arba priešfazinis).

2. Apskaičiuojama kiekvieno signalinio laidininko būdingoji varža pagal nurodytus pradinius konstrukcinius parametrus.

3. Palyginama vidurinių DML laidininkų ir nominalios būdingujų varžų absoliutus skirtumas. Jei apskaičiuota vidurinių laidininkų būdingoji varža didesnè arba mažesnè nei leistinas būdingosios varžos nuokrypis $\delta$, pereinama i 4 žingsni, jeigu neviršija leistino nuokrypio pereinama i 5 žingsni. 


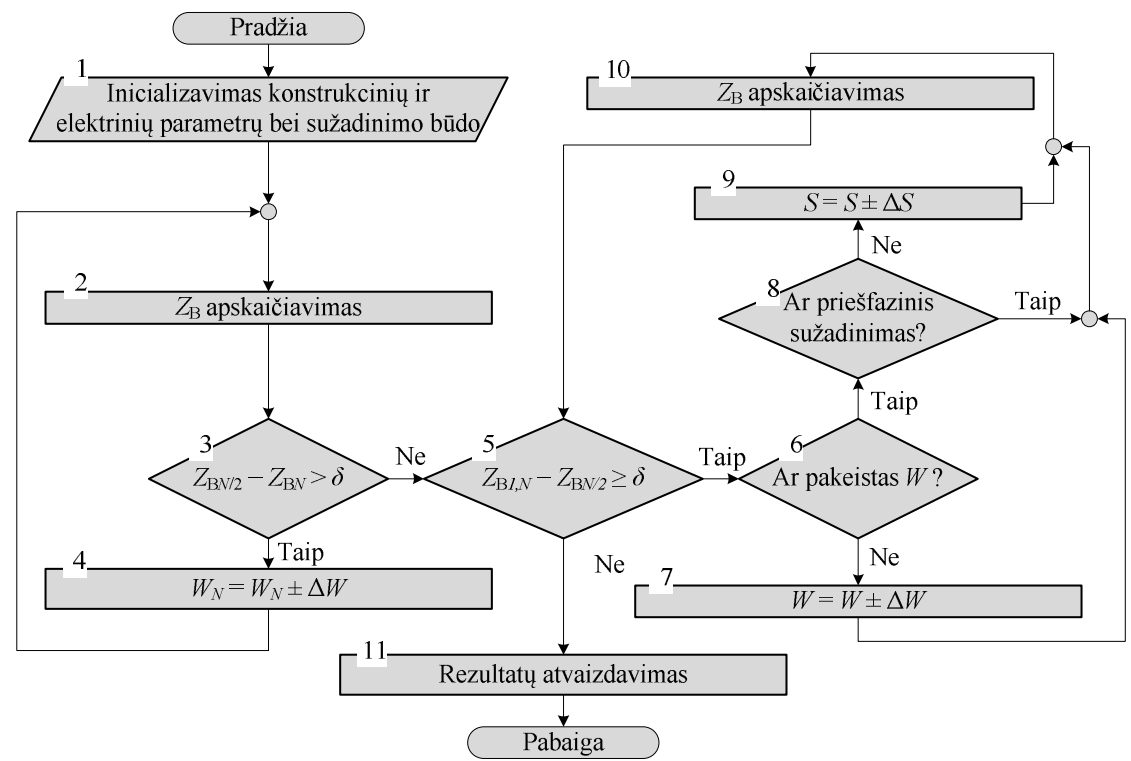

3.17 pav. Daugialaidès mikrojuostelinès linijos tolygios būdingosios varžos konstrukcinių parametrų sintezės, grịstos baigtinių skirtumų metodu, supaprastintas algoritmas

Fig 3.17. The simplified synthesis algorithm of the multiconductor microstrip line with uniform characteristic impedance structural parameters, based on finite difference method

4. Pagal apskaičiuotą būdingosios varžos vertę, padidinamas arba sumažinamas visų signalinių laidininkų plotis. Vietoj 2, 3, 4 žingsnių galima panaudoti periodinès DML konstrukcinių parametrų sintezès algoritmą sinfazinio sužadinimo atveju, kuris leidžia platesnị konstrukcinių parametrų pasirinkimą.

5. Tikrinamas išorinių ir vidinių signalinių laidininkų būdingụu varžų absoliutus skirtumas. Jeigu skirtumas didesnis nei nurodytas leistinas būdingosios varžos nuokrypis - pereinama į 6 žingsnį. Jeigu skirtumas mažesnis - pereinama ị 11 žingsnį.

6. Tikrinama ar buvo prieš tai keistas išorinių signalinių laidininkų plotis. Jei nebuvo keistas plotis - pereinama į 7 žingsni, jei buvo keistas plotis pereinama ị 8 žingsnị.

7. Padidinamas arba sumažinamas išorinių signalinių laidininkų plotis priklausomai nuo to ar šių laidininkų būdingosios varžos didesnès arba mažesnès nei leistinas būdingosios varžos nuokrypis. 
8. Tikrinama ar pasirinktas priešfazinis sužadinimo būdas. Jei šis būdas pasirinktas pakanka keisti tik išorinių laidininkų plotị, norint suvienodinti būdingąsias varžas ir pereinama ị 10 žingsnị. Jei pasirenkamas sinfazinis sužadinimo būdas, pakaitomis keičiamas išorinių signalinių laidininkų plotis ir tarpo plotis tarp išorinių ir vidinių signalinių laidininkų.

9. Padidinamas arba sumažinamas tarpo plotis tarp išorinių ir vidinių signalinių laidininkų, priklausomai nuo to ar šių laidininkų būdingosios varžos didesnès arba mažesnès nei leistinas būdingosios varžos nuokrypis.

10. Apskaičiuojama kiekvieno signalinio laidininko būdingoji varža pagal nurodytus pradinius konstrukcinius parametrus.

11. Atvaizduojami rezultatai su nustatytais konstrukciniais parametrais ir gauta būdingają varžą, esant tiems patiems konstrukciniams parametrams. Jei nepavyksta rasti konstrukcinių parametrų tam tikrai būdingajai varžai, parodomas atitinkamas pranešimas.

Sudarytas sintezės algoritmas leidžia gauti DML konstrukcinius parametrus, kai DML sužadinama sinfaziniu arba priešfaziniu būdu.

\subsubsection{Sintezès algoritmų tyrimas}

Sintezès algoritmų patikra buvo vykdoma dviem etapais. Pirmuoju etapu buvo patikrinta DML būdingosios varžos ir konstrukcinių parametrų sintezès nuokrypis nuo nominalių verčių. Antruoju etapu tikrinamas tolygios būdingosios varžos sintezės algoritmas ir šio algoritmo sintezuojamos būdingosios varžos nuokrypis nuo nominalios vertès (sintezuojama 8 bei 20 laidininkų DML, 3.18 ir

3.8 lentelè. Periodinės daugialaidès mikrojuostelinės linijos sintezės algoritmo patikros rezultatai

Table 3.8. Results of periodic multiconductor microstrip line synthesis algorithm

\begin{tabular}{|c|c|c|c|}
\hline \multirow{2}{*}{ DML konstrukciniai parametrai } & \multicolumn{3}{|c|}{$Z_{\text {Bnom }}, \Omega$} \\
\cline { 2 - 4 } & 50 & 75 & 120 \\
\hline$W / h$ & 2,25 & 1,4 & 0,8 \\
\hline$S / h$ & 1,0 & 0,8 & 0,6 \\
\hline$\varepsilon_{\mathrm{r}}$ & 6,0 & 6,0 & 6,0 \\
\hline Gauta būdingoji varža, $\Omega$ & 49,9 & 74,6 & 121,7 \\
\hline Nominalios vertės paklaida, \% & $-0,2$ & $-0,53$ & 1,42 \\
\hline
\end{tabular}




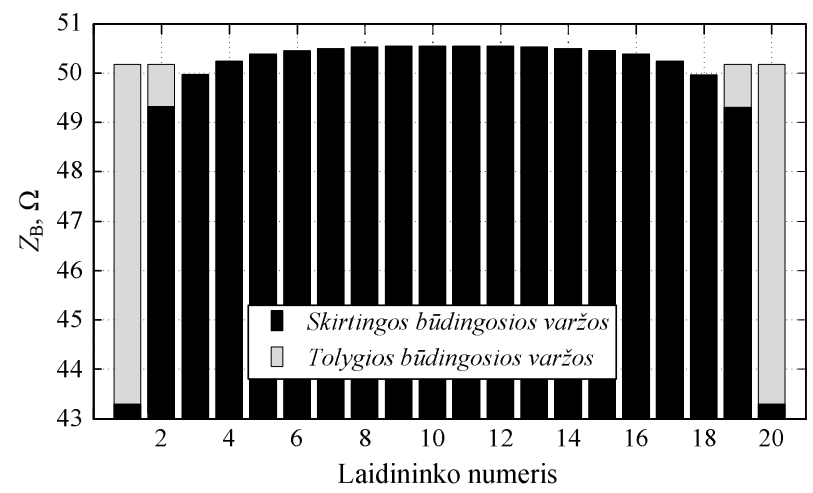

3.18 pav. Daugialaidès mikrojuostelinès linijos, grịstos periodinès daugialaidès mikrojuostelinès linijos (juoda spalva) ir tolygios būdingosios varžos (pilka spalva) sintezès algoritmų būdingosios varžos priklausomybès nuo laidininko numerio, kai $\varepsilon_{\mathrm{r}}=9,6 ; h=0,5 \mathrm{~mm}$;

$$
W=0,6 \mathrm{~mm} ; S=0,5 \mathrm{~mm} ; N=20
$$

Fig. 3.18. Conductors characteristic impedance of multiconductor microstrip line based on periodic multiconductor microstrip line (black color) and uniform characteristic impedance (grey color) synthesis algorithms, when $\varepsilon_{\mathrm{r}}=9.6 ; h=0.5 \mathrm{~mm} ; W=0.6 \mathrm{~mm} ; S=0.5 \mathrm{~mm} ; N=20$

3.19 paveikslai). Siūlomo algoritmo tikslumui patikrinti buvo susintezuotos trys DML (3.8 lentelè), kurių nominalios būdingosios varžos vertès yra atitinkamai 50,75 ir $120 \Omega$.

Pagal 3.8 lenteleje pateiktus duomenis matyti, kad periodinès daugialaidès mikrojuostelinès linijos sintezès nuokrypis nuo nominalios būdingosios varžos vertès neviršija $2 \%$. Skaičiavimo trukmès tyrimai šiuo atveju neatliekami, nes visi sintezuojamų linijų konstrukciniai parametrai gauti per trumpesnį laiką nei minute.

Atliekant tolygios būdingosios varžos DML sintezès algoritmo tyrimus, sintezuotos 20 ir 8 signalinių laidininkų daugialaidès mikrojuostelinès linijos. Kaip matyti iš pateiktų 3.18 ir 3.19 paveikslų, didžiausias būdingosios varžos skirtumas tarp vidinių ir išorinių laidininku yra vienodo pločio signalinių laidininkų DML atveju. Absoliutus skirtumas tarp vidinių ir išorinių laidininku gali siekti iki $14 \Omega$. Siekiant suvienodinti signalinių laidininkų būdingosios varžos vertes pakanka keisti tik išorinių laidininkų pločius. Nagrinèjamu atveju užtenka dešimties iteracijų, norint pasiekti $2 \Omega$ absoliutų skirtumą, mažesnis absoliutus 

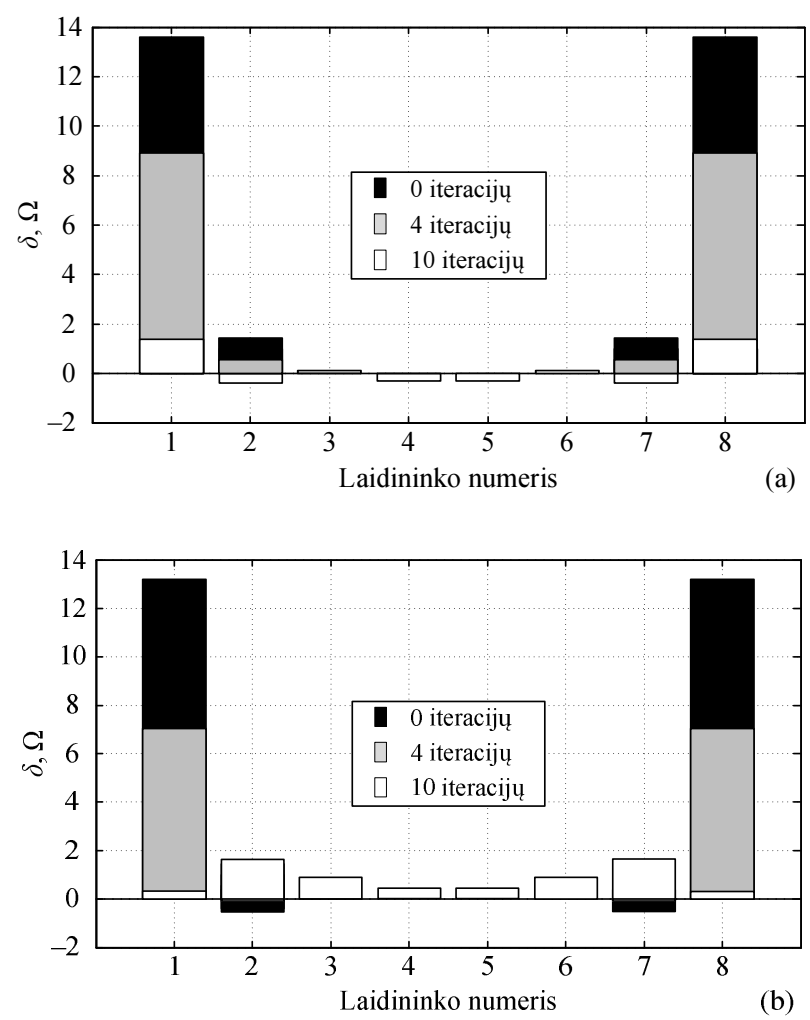

3.19 pav. Daugialaidès mikrojuostelinès linijos, grịstos tolygios būdingosios varžos sintezės algoritmu, kiekvieno laidininko absoliutus skirtumas tarp nominalios ir apskaičiuotos būdingosios varžos sinafazinio

(a) ir priešfazinio (b) sužadinimo atvejais, kai $\varepsilon_{\mathrm{r}}=9,6 ; h=0,5 \mathrm{~mm}$; $W=0,6 \mathrm{~mm} ; S=0,5 \mathrm{~mm} ; N=8$

Fig. 3.19. Conductors absolute difference of calculated and nominal characteristic impedance value of multiconductor microstrip line based on uniform characteristic impedance synthesis algorithm and operating in c (a) and $\pi$ (b) modes, when $\varepsilon_{\mathrm{r}}=9.6 ; h=0.5 \mathrm{~mm} ; W=0.6 \mathrm{~mm} ; S=0.5 \mathrm{~mm}$; $N=8$

skirtumas pasiekiamas mažinant tinklelio žingsnį, tačiau išauga iteracijų skaičius. DML signalinių laidininkų būdingają varžą galima suvienodinti tik tam tikram, konkrečiam linijos sužadinimo tipui. 


\subsection{Trečiojo skyriaus išvados}

Remiantis atliktais tyrimais ir jų rezultatų analize galima daryti šias išvadas:

1. Pasiūlyti susietųjų mikrojuostelinių linijų (SML) ir daugialaidžių mikrojuostelinių linijų (DML) modeliai, grịsti baigtinių skirtumų ir baigtinių skirtumų laiko srities metodais, leidžia tirti nereguliarias meandrines mikrojuostelines vélinimo linijas, sudarytas iš baigtinio strypu skaičiaus.

2. Pasiūlytos SML ir DML srovès ir įtampos skaičiavimo metodikos leidžia iš elektrinio ir magnetinio laukų pokyčių laike apskaičiuoti linijų būdingưjų varžų ir efektyviưjų dielektrinių skvarbų dažnines priklausomybes. Nustatyta, kad santykinis skirtumas apskaičiuotu verčių, gautų taikant sudarytuosius modelius bei pasiūlytąsias skaičiavimo metodikas, ir verčių, pateiktų kitų tyrèjų, neviršija $10 \%$.

3. Sudarytieji SML ir DML modeliai leidžia analizuoti linijas veikiančias normaliųjų bangų režimu (angl. eigen mode), kuomet ties laidininkais sklindančių elektromagnetinių bangų faziniai greičiai yra vienodi. Kompiuterinis SML ir DML imitavimas, taikant sudarytuosius modelius, parodè, kad linijos, veikiančios normaliosios bangos rěžimu ir sužadintos sinfaziniu būdu (angl. c-mode), santykinis skirtumas efektyviosios dielektrinès skvarbos ties signaliniais laidininkais neviršija $1 \%$, o linijos, sužadintos priešfaziniu būdu (angl. $\pi$-mode) $-3 \%$.

4. Sudarytuose SML ir DML modeliuose taikomas kvazistatinis artinys, todèl įtampos bei srovès skaičiavimuose neįvertinamos elektrinio ir magnetinio laukų išilginès komponentès atsirandančios aukštesniuosiuose analizès dažniuose. Didejjant dažniui šios išilginès komponentès didèja, kartu didejja ir skaičiavimo rezultatų neapibrěžtis. Siekiant mažesnès analizès neapibréžties, minètas išilgines komponentes ịvertinti būtina tai artimiausios ateities uždavinys.

5. Kompiuteriniai eksperimentai, atlikti taikant DML modeli parodè, kad elektromagnetinès bangos sklidimo fazinio greičio dispersija ir išilgai mikrojuostelių sklindančių signalų tarpusavio įtaka didesnè, kai tarpai tarp laidininkų siauresni, o dèl šios priežasties vidinių laidininkų vèlinimo trukmè yra didesné, kai DML sužadinama vienodo dydžio įtampomis.

6. Tyrimai parodè, kad didžiausią įtaka DML būdingosios varžos tolygumui daro išoriniai laidininkai. Taigi, norint suvienodinti būdingają varžą visoje linijoje, užtenka keisti tik išorinių laidininkų plotị.

7. Pasiūlyti netolygios ir tolygios būdingosios varžos DML sintezès algoritmai leidžia rasti periodinès ir neperiodinès daugialaidès mikrojuoste- 
linès linijos konstrukcinius parametrus, kai būdingosios varžos santykinis skirtumas neviršija $1 \%$ ir $2 \%$ atitinkamai. 


\section{4}

\section{Meandrinès mikrojuostelinès vèlinimo linijos modeliu sudarymas ir tyrimas}

Šiame skyriuje sudaromi du meandrinès mikrojuostelinès vèlinimo linijos (MMVL) modeliai, grịsti atitinkamai baigtiniu skirtumų laiko srities (BSLS) metodu ir daugialaidžių linijų bei baigtinių skirtumų metodų deriniu ir tiriamos šių vèlinimo linijų dažninių charakteristikų priklausomybès nuo linijos konstrukcinių parametrų. Pasiūlytų MMVL modelių analizès rezultatai lyginami su rezultatais gautais, naudojant specializuotus programu paketus CST Microwave Studio $^{\circledR}$ bei Sonnet ${ }^{\circledR}$. Nagrinejjama daugialaides mikrojuostelinès linijos (DML) laidininkų parametrų netolygumo įtaka MMVL charakteristikoms.

Skyriaus tema paskelbtas vienas autoriaus straipsnis (Krukonis et al. 2013).

\subsection{Meandrinès mikrojuostelinès vẻlinimo linijos modelis, grịstas baigtinių skirtumų laiko srities metodu}

Mikrojuostelinès meandrinès vèlinimo linijos plačiai taikomos įvairiose elektroninèse sistemose, pvz., analoginių signalų apdorojimui realiuoju laiku 
(Horii et al. 2012), analogas - skaičius keitikliuose (Guansheng et al. 2009), signalų sinchronizavimo itaisuose (Hsi-Chou, Jyh-Horng 2007), o taip pat kaip svarbi ịvairių kitų elektrodinaminių ir elektroninių prietaisų dalis (Daškevičius et al. 2010; Kim et al. 2007).

Šiuo metu plačiai naudojamos iš aktyviujų elementų sudarytos vèlinimo linijos (VL) (Kim et al. 2007; Wei-Tsung et al. 2013). Tačiau elektrodinaminès VL pasižymi daugeliu pranašumu, pvz.: plati, nuo nulio prasidedanti pralaidumo juosta, charakteristiku tiesiškumas ir stabilumas, mažesnis energijos poreikis (Urbanavičius et al. 2009). Elektrodinaminèse VL vèlinimas sąlygojamas baigtiniu elektromagnetinès bangos sklidimo greičiu išilgai nustatyto kelio ir apibūdinamas vèlinimo trukme. Siekiant padidinti vèlinimo trukmę, nedidinant VL matmenų, elektromagnetinès bangos sklidimo kelias ilginamas formuojant meandro arba spiralès formos signalų laidininką. Tokiu būdu VL struktūra tampa periodine, turinčia savitą meandro strypų arba spiralès vijų atsikartojimo periodą, todėl tokių linijų analizei ir modeliavimui plačiai taikomas daugialaidžių liniju metodas (Daškevičius et al. 2010). Šis metodas reikalauja palyginus mažai skaičiavimo resursų, o tai ypač svarbu VL sintezei (Katkevičius et al. 2012; Štaras et al. 2012) projektuojant mikrobangu ịtaisus. Remiantis šiuo metodu, modeliuojama daugialaide linija ir ją atitinkančios VL yra periodinès ir be galo ilgos, sudarytos iš be galo daug vienodo pločio laidžiujų strypų, atstumai tarp kurių taip pat vienodi. Realių VL, grịstų begaline daugialaide linija, kurių dydis yra baigtinis, parametru pasiskirstymas laidininkuose yra netolygus dèl elektromagnetinio lauko sklaidos linijos galuose ir kraštuose (Metlevskis, Urbanavičius 2011).

Poskyryje pateikiamas MMVL matematinis modelis, grịstas baigtinių skirtumų laiko srities metodu ir idealiai suderinto absorbuojančio sluoksnio paradigma. Sudaromas algoritmas, leidžiantis analizuoti MMVL, nurodant konstrukcinius parametrus, ir tiriamos vélinimo linijos elektrinès charakteristikos plačiame dažnių diapazone.

\subsubsection{Meandrinès mikrojuostelinès vèlinimo linijos analizès algoritmas}

Apibendrintas meandrinès mikrojuostelinès vèlinimo linijos konstrukcijos eskizas pateiktas 4.1 paveiksle. MMVL sudaro meandro formos signalo laidininkas suformuotas ant dielektrinio pagrindo, kurio kita pusé dengta ištisiniu laidžiu sluoksniu (ekranu). Pagrindiniai MMVL elektriniai parametrai ir charakteristikos yra šie: vèlinimo trukmè $t_{\mathrm{v}}$, būdingoji varža $Z_{\mathrm{B}}$, praleidžiamujų dažnių juosta $\Delta f$, vèlinimo trukmès $t_{\mathrm{v}}(\omega)$ ir būdingosios varžos $Z_{\mathrm{B}}(\omega)$ priklausomybès nuo dažnio. 


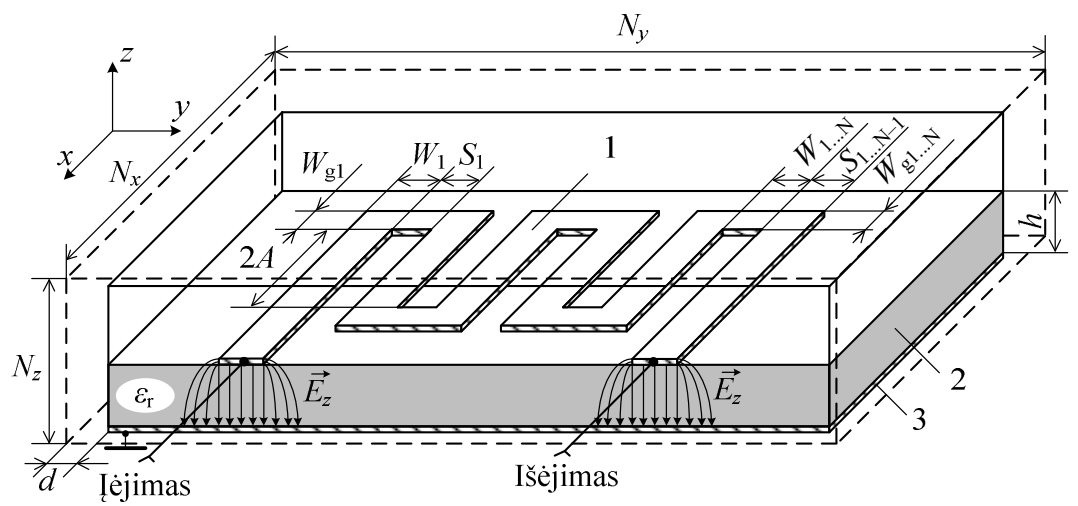

4.1 pav. Meandrinès mikrojuostelinès vèlinimo linijos sandara: 1 - signalo laidininkas; 2 - dielektrinis pagrindas; 3 - ištisinis laidininkas (ekranas)

Fig. 4.1. Structure of meander microstrip delay line: 1 - signal conductors; 2 - dielectric substrate; 3 - reference conductor (shield)

Mikrojuostelinès meandrinès vèlinimo linijos, grịstos baigtinių skirtumų laiko srities metodu, elektrinių parametru skaičiavimo algoritmas pateiktas 4.2 paveiksle. Algoritmą sudaro 16 žingsnių:

1. Ivedami analizuojamos meandrinès mikrojuostelinès vèlinimo linijos konstrukciniai parametrai: $h$-dielektrinio pagrindo storis, $\varepsilon_{r}$ - pagrindo dielektrinè skvarba; $2 A$ - meandro aukštis; $W_{1 \ldots N}-$ meandro strypu pločiai; $S_{1 \ldots N-1}-$ tarpų tarp meandro strypu pločiai; $W_{g 1 \ldots N}-$ kraštinių trumpiklių, jungiančių meandro strypų galus, pločiai; $d$ - absorbuojančio sluoksnio storis. Inicializuojamos elektrinès ir magnetinès indukcijos bei elektrinio ir magnetinio lauku stiprio matricos $[D],[B],[E]$ ir $[H]$ atitinkamai.

2. Inicializuojamos ir apskaičiuojamos vienaašio idealiai suderinto absorbuojančio sluoksnio koeficientų matricos.

3. Inicializuojamos meandrinès mikrojuostelinès vèlinimo linijos išsidèstymo $E_{x}, E_{y}$ elektrinių ir $H_{z}$ magnetinio laukų komponenčių koordinačių matricos - atitinkamai $[m E x],[m E y]$ ir $[m H z]$. Šios išsidèstymo koordinačių matricos nurodo, kaip išsidèsčiusi MMVL nagrinèjamoje srityje.

4. Apskaičiuojamos pirmojo MMVL meandrinio strypo, kurio plotis $W_{1}$ ir aukštis $2 A$ pozicija nagrinejjamoje srityje. 


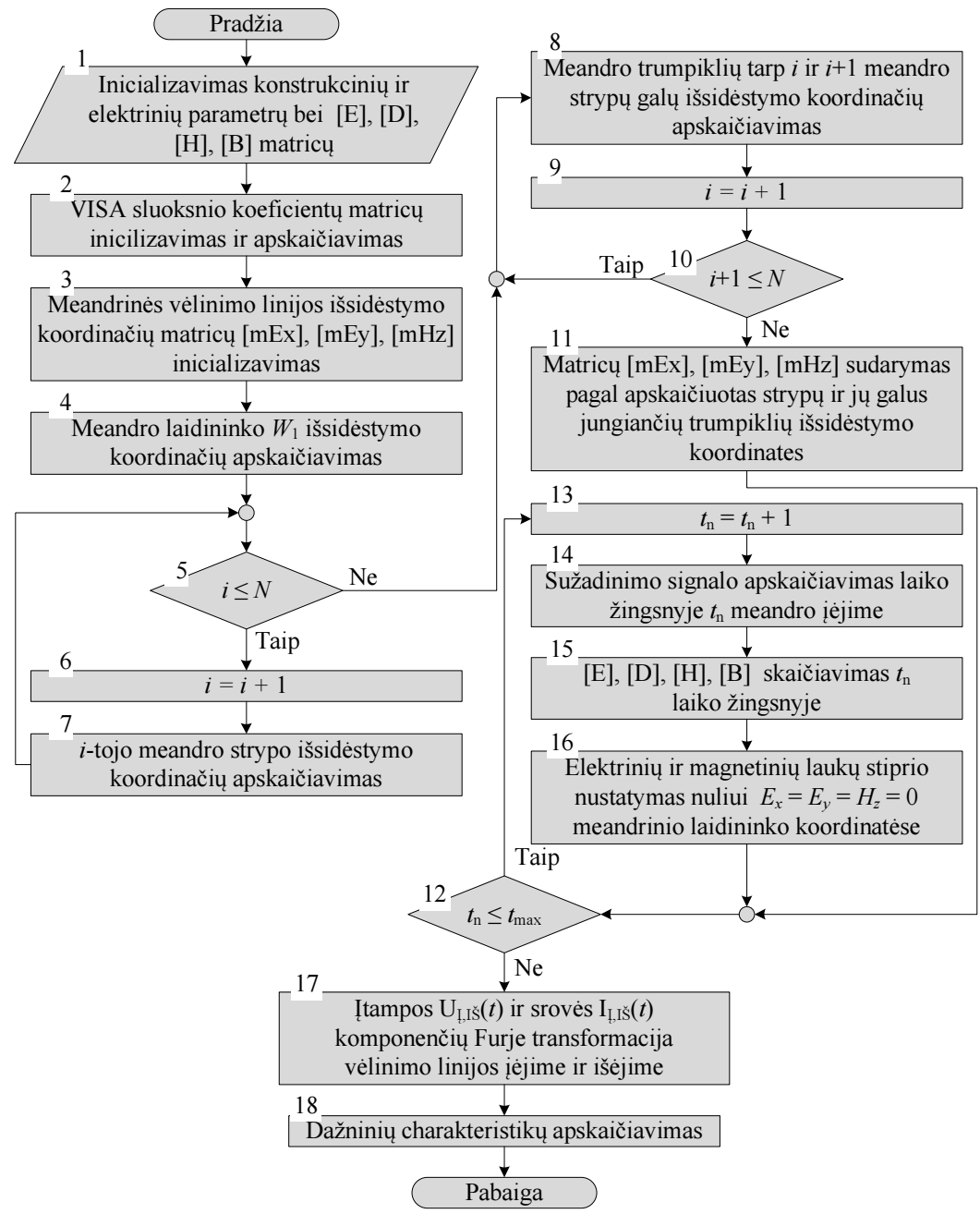

4.2 pav. Meandrinės mikrojuostelinès vèlinimo linijos modelio, grịsto baigtinių skirtumų laiko srities metodu, supaprastintas algoritmas

Fig. 4.2. The simplified algorithm of the meander microstrip delay line model based on finite difference time domain method

5. Pradedamas likusių strypų $W_{i}$ išsidèstymo koordinačių apskaičiavimo ciklas. Lyginama ar apskaičiuotas $i$-tasis strypas yra paskutinis MMVL. Ciklas baigiamas, kai apskaičiuojamos paskutinio $N$-tojo meandro strypo išsidèstymo koordinatès.

6. 9. Žingsniuose padidinamas strypo numeris vienetu. 
7. Analizuojamos VL išsidèstymo koordinačių apskaičiavimas pradedamas nuo antrojo $(i=2)$ meandro strypo išsidèstymo koordinačių elektriniame $E_{x}, E_{y}$ ir magnetiniame $H_{z}$ laukuose, kai tarpas tarp prieš tai skaičiuoto strypo ir skaičiuojamo yra $S_{i-1}$.

8. Vykdomas meandro strypų trumpiklių $W_{g i}$ išsidèstymo koordinačių apskaičiavimas (skaičiavimas pradedamas tarp pirmojo ir antrojo strypu).

10. Trumpiklių išsidèstymo koordinačių skaičiavimu ciklas vykdomas tol, kol apskaičiuojamos visos meandro strypų galų koordinatès.

11. Pagal apskaičiuotas meandro strypų ir jų galų trumpiklių išsidèstymo koordinates sudaromos $[m E x],[m E y]$ ir $[m H z]$ koordinačių matricos. Siekiant modeliuoti suderintajj signalu šaltini ir apkrovą pirmojo strypo iejjimas ir paskutiniojo strypo išèjimas tariamai pratęsiami ị absorbuojantị sluoksnį. Apskaičiuojamos pratęstų strypų išsidèstymo koordinatès.

12. Pradedamas signalo sklidimo išilgai meandrinio laidininko skaičiavimo ciklas. Skaičiavimo procesas šiuo atveju vykdomas tol, kol pasiekiamas didžiausias nurodytas analizès laiko žingsnis $t_{\text {max }}$.

13. Skaičiavimų ciklas pradedamas, kai laiko žingsnis $t_{\mathrm{n}}$ lygus nuliui, kiekvieno sekančio ciklo metu laiko žingsnis inkrementuojamas vienetu.

14. Kiekvieno ciklo metu MMVL iejjime perskaičiuojamo Gauso sužadinimo impulso momentinès vertès. Sužadinimas modeliuojamas nurodant atitinkamą elektrinio lauko stiprị dielektriniame pagrinde (4.1 pav.) visame signalinio laidininko plote $W_{1}$.

15. Kiekviename analizès laiko žingsnyje $t_{\mathrm{n}}$ perskaičiuojamos elektrinès ir magnetinès indukcijos bei elektrinio ir magnetinio laukų stipriu komponenčių matricos. Be to, tame pačiame laiko žingsnyje $t_{\mathrm{n}}$ apskaičiuojamos ir išsaugomos įtampos ir srovès momentinès reikšmès MMVL iejjime ir išèjime.

16. Kiekviename analizès laiko žingsnyje, atsižvelgus ị koordinačių matricas $[m E x],[m E y]$ ir $[\mathrm{mHz}]$, elektrinio ir magnetinio laukų stiprio komponentès $E_{\mathrm{x}}, E_{\mathrm{y}}$ ir $H_{\mathrm{z}}$ prilyginamos nuliui, taip modeliuojant idealuji meandrini laidininką.

17. Siekiant apskaičiuoti MMVL dažnines charakteristikas atliekama įtampos $U_{\mathrm{I}, \breve{s}}(t)$ ir srovès $I_{\mathrm{t}, \breve{s}}(t)$ ièjime ir išèjime Furje transformacija.

18. Iš įtampos $U(\omega)$ ir srovès $I(\omega)$ santykio apskaičiuojama MMVL būdingoji varža, o iš įtampos iejjime ir išejime santykio apskaičiuojama bangos sklidimo fazès koeficiento priklausomybè nuo dažnio $\beta(\omega)$. Iš bangos fazès koeficiento $\beta(\omega)$ apskaičiuojama efektinè dielektrinè skvarba $\varepsilon_{\mathrm{r}}(\omega)$. 


\subsubsection{Meandrinès mikrojuostelinès vèlinimo linijos modelio tyrimas}

Pasiūlytas meandrinès mikrojuostelinès vèlinimo linijos modelis, grịstas baigtinių skirtumų laiko srities metodu, tikrinamas pasitelkiant specializuotą programų paketą Sonnet ${ }^{\circledR}$. MMVL modelio adekvatumas tikrinamas lyginant apskaičiuotas MMVL dažnines charakteristikas su analogiškomis charakteristikomis, gautomis analizuojant tos pačios topologijos modelius, sudarytus Sonnet $^{\circledR}$ specializuotu programų paketu. Šiems skaičiavimams panaudota penkių
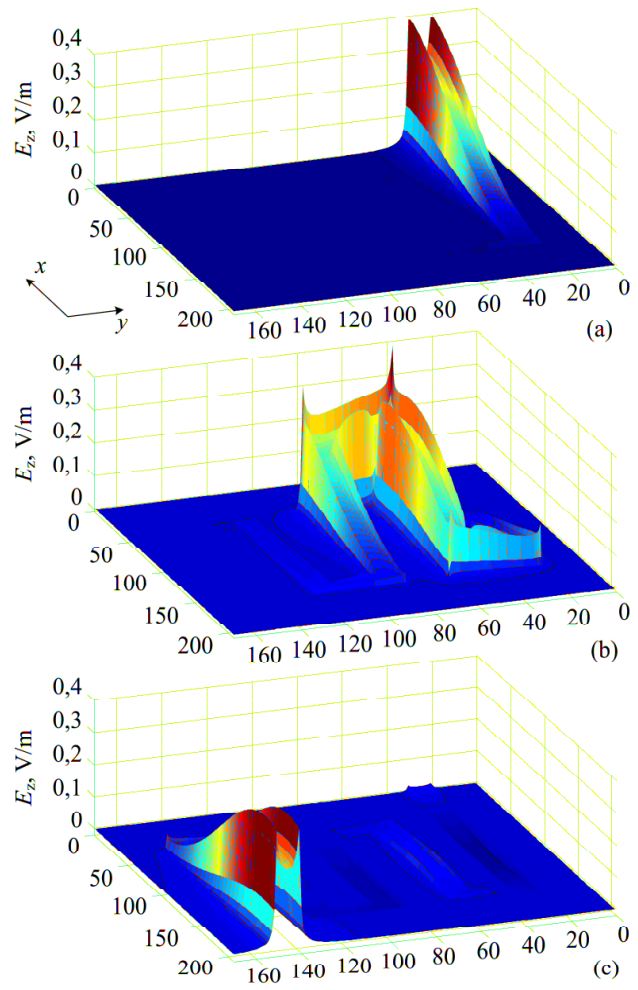

4.3 pav. Gauso impulso sklidimo iliustracija meandrinèje vèlinimo linijoje: a) impulsas linijos ièjime; b) impulsas linijos vidurinèje dalyje; c) impulsas linijos išejime

Fig. 4.3. Illustration of Gauss impulse propagation in meander delay line: a) impulse in the beginning of the line; b) impulse in the middle of the line; c) impulse at the end of the line 
$(N=5)$ strypų MMVL, kurios konstrukciniai parametrai yra šie: dielektrinio pagrindo storis $h=0,5 \mathrm{~mm}$; dielektrinio pagrindo skvarba $\varepsilon_{\mathrm{r}}=9,6$; meandro strypų ir strypų galus jungiančių trumpiklių pločiai $W_{1 . .5}=W_{g}=1 \mathrm{~mm}$; tarpai tarp meandro strypu $S_{1 \ldots 4}=1 \mathrm{~mm}$.

Gauso impulso sklidimo penkių laidininkų meandrinès mikrojuostelinès linijos ịvairiose vietose iliustracija pateikta 4.3 paveiksle. Šiose iliustracijose matyti elektrinio lauko stiprio $E_{\mathrm{z}}$ komponentès pasiskirstymas po signaliniu laidininku, sklindant Gauso impulsui.

Iš 4.4 paveikslo matyti, kad baigtinių skirtumų laiko srities metodu apskaičiuoto sklaidos parametro $S_{12}$ modulio dažninè charakteristika ne visai sutampa su Sonnet ${ }^{\circledR}$ programu paketu apskaičiuota analogiška charakteristika. Tarkime, dažnių srityje nuo 0 iki $2 \mathrm{GHz}$ minètų charakteristikų skirtumas neviršija $2 \mathrm{~dB}$, tačiau srityje virš $2 \mathrm{GHz}$ pagal siūlomą modeli apskaičiuota charakteristika laipsniškai mažeja, tuo tarpu Sonnet ${ }^{\circledR}$ programų paketu apskaičiuotoje charakteristikoje pastebimas rezonanso požymis ties $4,7 \mathrm{GHz}$ dažniu. Toks charakteristikų skirtumas gali būti visų pirma paaiškintas sistemine priežastimi - Sonnet ${ }^{\circledR}$ programų paketas grịstas momentų metodu. Kita vertus neįmanoma visiškai suvienodinti siūlomo MMVL modelio ir Sonnet ${ }^{\circledR}$ analizès parametrų, pvz., erdvinès gardelès, laiko ir dažnio žingsnių. Pastebètina, kad nepaisant vizualaus $\mathrm{S}_{12}$ parametro dažninių charakteristikų skirtumo, praleidžiamujų dažnių juostų skirtumas, nustatytas pagal šias charakteristikas, neviršija $25 \%$.

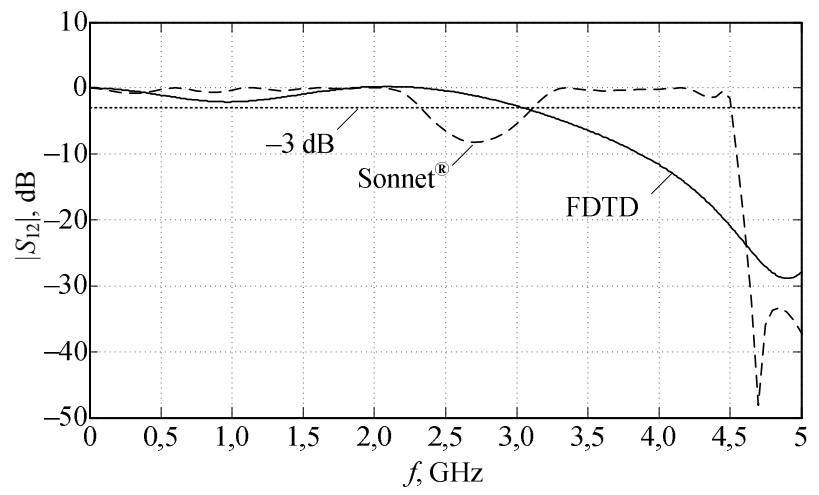

4.4 pav. Meandrinès mikrojuostelinès vèlinimo linijos perdavimo charakteristikos ( $S_{21}$ parametras) modulio priklausomybė nuo dažnio, kai $\varepsilon_{\mathrm{r}}=9,6 ; h=0,5 \mathrm{~mm} ; 2 A=20 \mathrm{~mm} ; S_{4}=1 \mathrm{~mm} ; W_{1 . .5}=W_{\mathrm{g}}=1 \mathrm{~mm} ; N=5$

Fig. 4.4. Frequency response of parameter $S_{21}$ magnitude of the meander microstrip delay line which design parameters are following: $\varepsilon_{\mathrm{r}}=9.6$;

$h=0.5 \mathrm{~mm}, 2 A=20 \mathrm{~mm} ; S_{4}=1 \mathrm{~mm} ; W_{1 . .5}=W_{\mathrm{g}}=1 \mathrm{~mm} ; N=5$ 

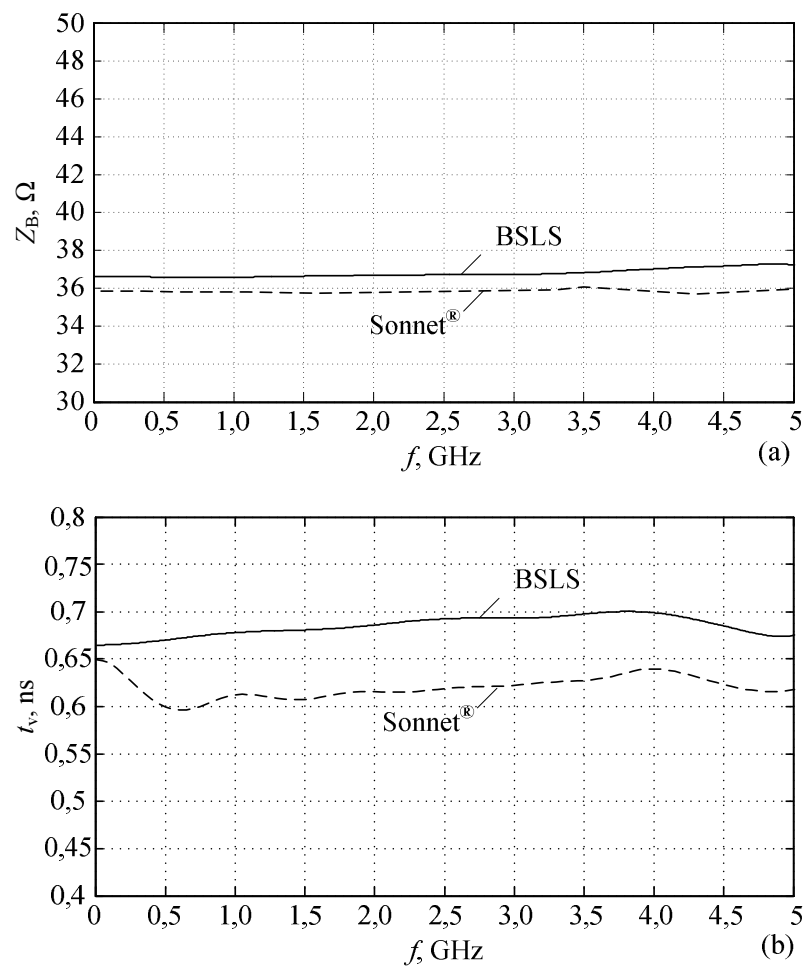

4.5 pav. Meandrinès mikrojuostelinès vèlinimo linijos būdingosios varžos

(a) ir vèlinimo laiko (b) priklausomybè nuo dažnio, kai $\varepsilon_{\mathrm{r}}=9,6$;

$$
\begin{gathered}
h=0,5 \mathrm{~mm} ; 2 A=20 \mathrm{~mm} ; S_{1 \ldots 4}=1 \mathrm{~mm} ; \\
W_{1 \ldots 5}=W_{\mathrm{g}}=1 \mathrm{~mm} ; N=5
\end{gathered}
$$

Fig. 4.5. Characteristic impedance (a) and delay time (b) dependency on frequency of the meander microstrip delay line which design parameters are following: $\varepsilon_{\mathrm{r}}=9.6, h=0.5 \mathrm{~mm}, 2 A=20 \mathrm{~mm}, S_{4}=1 \mathrm{~mm}$;

$$
W_{1 \ldots 5}=W_{\mathrm{g}}=1 \mathrm{~mm} ; N=5
$$

Iš 4.5 paveikslo a ir b kreivių matyti, kad abiem būdais apskaičiuotos būdingosios varžos bei vèlinimo laiko dažninès charakteristikos kitimas yra panašaus pobūdžio. Santykinis skirtumas tarp BSLS metodu grịsto modelio ir Sonnet $^{\circledR}$ programų paketu gautų rezultatų būdingosios varžos atveju neviršyja $3 \%$, vèlinimo trukmès atveju neviršyja $15 \%$. 


\subsection{Meandrinès mikrojuostelinès vèlinimo linijos modelio, grịsto daugialaidès linijos metodu, sudarymas ir tyrimas}

İvairiems įtaisams mikrobangų diapazone modeliuoti vis dažniau taikomi specializuoti programų paketai (Metlevskis, Martavičius 2012). Šiame poskyryje, siekiant atskleisti meandro strypų sąryšio įtaką vèlinimo linijų savybèms, sudaryti ir ištirti dviekranių meandrinių mikrojuostelinių vèlinimo linijų (DMMVL) modeliai, grịsti daugialaidžių linijų metodu, o taip pat taikant specializuotus programų paketus CST Microwave Studio ${ }^{\circledR}$ ir Sonnet ${ }^{\circledR}$. Sudarytuose DMMVL modeliuose keičiant meandro žingsni taip, kad bendras DMMVL signalinio laidininko ilgis išliktų nepakitęs, apskaičiuotos vèlinimo trukmès dažninès priklausomybès. Gautos priklausomybès išanalizuotos ir palygintos su (Rubin, Singh 2000) darbe skelbtais rezultatais.

\subsubsection{Dviekranès meandrinès mikrojuostelinès vèlinio linijos tyrimo modeliai}

Nagrinejjamų DMMVL struktūros sudarytos remiantis (Rubin, Singh 2000) darbu. Siame darbe DMMVL matmenys pateikti JAV matavimo vienetais - coliais ir colių tūkstantosiomis dalimis, todèl tiriamų struktūrų matmenys pagal SI sistemą parenkami kaip galima artimesni pateiktoms straipsnyje ir suapvalinti iki antrojo, trečiojo ženklo po kablelio. Iš viso nagrinèjamos penkios vẻlinimo struktūros (4.6 pav.): tiesi dvieekrané perdavimo linija, kurios ilgis - 140,5 mm bei keturios meandrinès vèlinimo linijos, kurių signalinio laidininko bendras ilgis išlieka toks pats $-140,5 \mathrm{~mm}$, tačiau ilgis $x$ ašies kryptimi yra $104,9 \mathrm{~mm}$ (toks tariamasis ilgio sumažinimas susidaro dèl to, kad meandrinèse vèlinimo linijose signalas sklinda zigzagu). Kiekvieną DMMVL sudaro keturiolika $W \cong 0,084 \mathrm{~mm}$ pločio ir $2 A \cong 2,372 \mathrm{~mm}$ aukščio meandro strypų. Viena nuo kitos DMMVL tesiskiria tarpais tarp meandro strypu $S$, kurie, didejjimo tvarka, yra tokie: $0,17 \mathrm{~mm}, 0,297 \mathrm{~mm}, 0,678 \mathrm{~mm}$ ir $1,44 \mathrm{~mm}$. Meandro žingsnis $L-$ atstumas tarp gretimų strypų centrų, šiuo atveju taip pat skirtingas ir, atitinkamai, yra toks: $0,254 \mathrm{~mm}, 0,381 \mathrm{~mm}, 0,762 \mathrm{~mm}$ ir $1,524 \mathrm{~mm}$. Nagrinejjamas meandrines vélinimo linijas ir tiesią perdavimo liniją gaubia dielektriné terpé, kurios santykinè dielektrinè skvarba $\varepsilon_{\mathrm{r}}=3,9$. Šią terpę iš išorès dengia du laidieji ekranai. Dielektrinès terpès storis $-h=h_{1}+h_{2}=0,404 \mathrm{~mm}$. Signalinis laidininkas - varis, kurio savitasis laidumas yra $5,4 \cdot 10^{4} \mathrm{~S} / \mathrm{m}$, laidininko storis $0,03 \mathrm{~mm}$. 


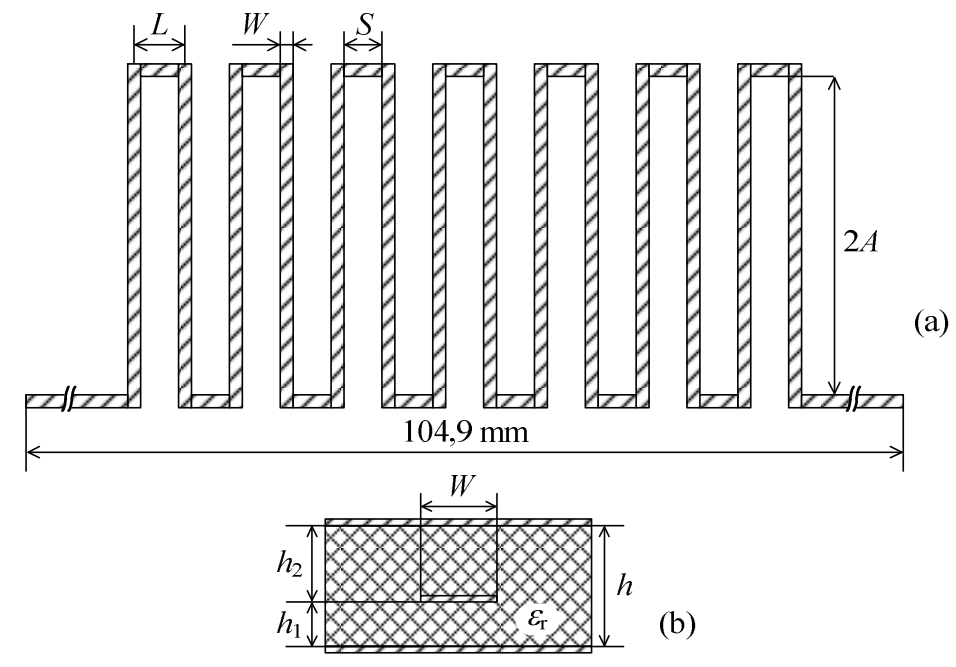

4.6 pav. Nagrinejjamų vèlinimo struktūrų topologija (a) ir skersinis pjūvis (b)

Fig. 4.6. Topology (a) and cross-section (b) of investigated time delay structures

Tyrimams atlikti naudojamas daugialaidžių linijų metodas ir du specializuoti programų paketai: Sonnet ${ }^{\circledR}$, kuriame naudojamas momentų analizès metodas, ir CST Microwave Studio ${ }^{\circledR}$, kuriame naudojamas baigtinių skirtumų laiko srities metodas.

\subsubsection{Dviekranių meandrinių mikrojuostelinių vèlinimo linijų modeliavimo rezultatai}

Modeliuojamų DMMVL vèlinimo trukmès dažninès priklausomybès, apskaičiuotos naudojant specializuotus programų paketus CST Microwave Studio ${ }^{\circledR}$ ir Sonnet ${ }^{\circledR}$, pateiktos 4.7 paveiksle, o 4.1 lentelèje - vèlinimo trukmių vertès, apskaičiuotos žemuosiuose ir aukštuosiuose nagrinejjamo ruožo dažniuose. Čia pat, palyginimui, pateiktos ir (Rubin, Singh 2000) darbe gautos vèlinimo trukmès vertès. Pažymètina, kad (Rubin, Singh 2000) darbe vèlinimo trukmé nustatoma kaip laiko skirtumas tarp sumodeliuotų impulsų šlaitų 0,5 lygyje tam tikros vèlinimo struktūros iejejime ir išejime, tuo tarpu specializuotų programų paketų CST Microwave Studio ${ }^{\circledR}$ ir Sonnet ${ }^{\circledR}$ atveju vèlinimo trukmè nustatoma iš sumodeliuotos struktūros sklaidos parametro $S_{12}$ argumento pagal tokią formulę:

$$
t_{d}(f)=\frac{\theta}{2 \pi f},
$$


čia $\theta$ - fazių skirtumas tarp iejjimo ir išèjimo virpesių ( $S_{12}$ parametro argumentas), radianais.

Vèlinimo trukmės priklausomybėse, pateiktose 4.7 paveiksle, pastebimi pasikartojantys netolygumai - kas $450 \mathrm{MHz}$ pasikartojantys ,išmetimai“ priklausomybèse, gautose naudojant CST Microwave Studio ${ }^{\circledR}$ programų paketą ir $550 \mathrm{MHz}$ gęstantys periodiški svyravimai priklausomybèse, gautose naudojant Sonnet ${ }^{\circledR}$ programų paketą. Periodiškumas šių netolygumų atitinka pusė bangos ilgio, telpančio tarp nagrinèjamų vèlinimo struktūrų ịejimo ir išejjimo pjūvių ir gali būti sąlygojami atspindžiais nuo nesuderinamų tarp signalinių traktų struktūros, signalų šaltinio ir apkrovos.
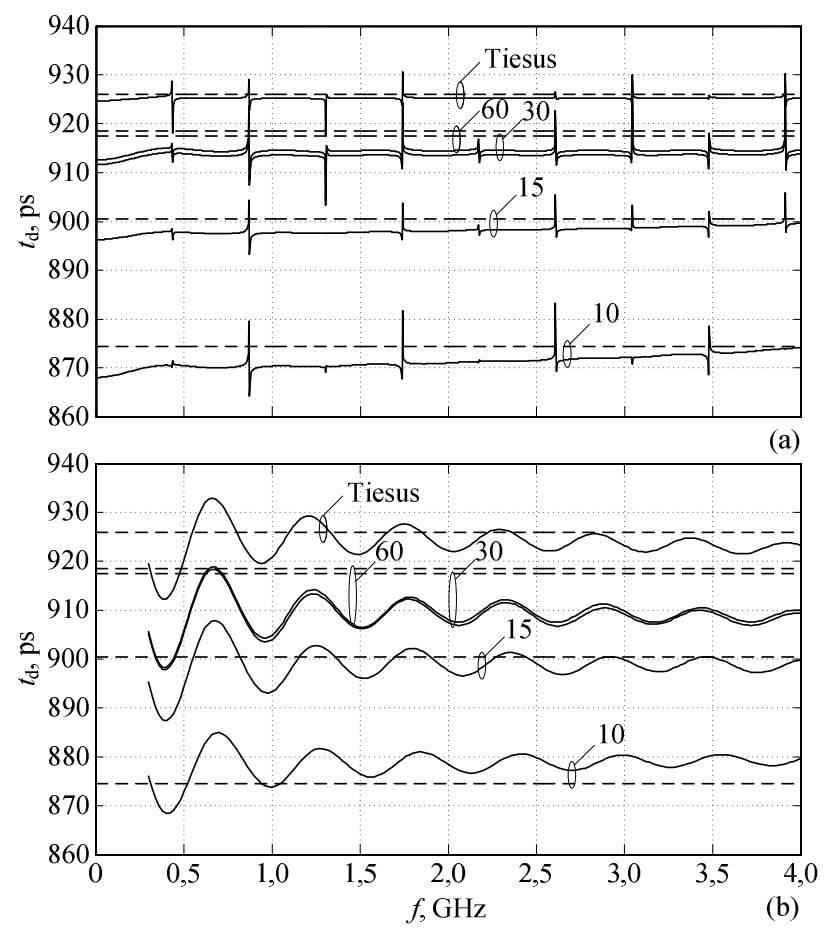

4.7 pav. Vèlinimo trukmès priklausomybès nuo dažnio, gautos CST Microwave Studio $^{\circledR}$ (a) ir Sonnet ${ }^{\circledR}$ (b) programų paketais. Brūkšninèmis linijomis pažymètos (Rubin, Singh 2000) darbe gautos vèlinimo trukmès vertès

Fig. 4.7. Delay time dependency on frequency, calculated with CST Microwave Studio $^{\circledR}$ (a) and Sonnet ${ }^{\circledR}$ (b) program packages. Delay time calculated values by (Rubin, Singh 2000) are marked as dashed lines 
Dèl 4.7 paveiksle pasirinkto mastelio dažninių priklausomybių netolygumai atrodo dideliais, tačiau, jie neviršija \pm 12 ps visame analizuojamų dažnių ruože, t. y. modeliuojamų DMMVL faziniai iškraipymai nustatyti iš nelygybès:

$$
\Delta t_{\mathrm{d}}(f) \leq \frac{0,0557}{f} .
$$

Iškraipymai neviršija $\pm 0,35$ rad (4.1 lentelè) ir tokiu būdu neturi įtakos linijų praleidžiamujų dažnių juostai.

Lyginant tarpusavyje įvairiais programų paketais modeliuotu DMMVL vèlinimo trukmių vertes, matyti, kad nepaisant to, jog signalų sklidimo kelias visų liniju vienodas - 140,5 mm - zigzagu t. y. meandriniu laidininku sklindančio signalo vèlinimo trukmè visuomet mažesnè negu signalo, sklindančio tiesine perdavimo linija (4.2 lentelè). Šj signalo „pagreitèjimą“ galima paaiškinti meandro strypu ilginès talpos mažèjimu, lyginant su tiesiniu laidininku, dèl abipusio strypu sąryšio, o taip pat papildomu DMMVL ilginès talpos sumažejimu meandrinio laidininko sulinkimo vietose (,posūkiuose“).

4.1 lentelè. Vèlinimo trukmès nukrypimai tarp vèlinimo linijos idealios ir realios FDCh, neviršijantys $\pm 0,35 \mathrm{rad}$

Table 4.1. Deviations of time delay between delay line ideal and real phase frequency characteristics, which doesn't exceeds $\pm 0.35 \mathrm{rad}$

\begin{tabular}{|c|c|c|c|c|c|c|c|}
\hline$f, \mathrm{GHz}$ & 0,01 & 0,1 & 0,5 & 1,0 & 2,0 & 3,0 & 4,0 \\
\hline$\Delta t_{\mathrm{d}}, \mathrm{ps}$ & \pm 5570 & \pm 557 & $\pm 111,4$ & $\pm 55,7$ & $\pm 27,8$ & $\pm 18,7$ & $\pm 13,9$ \\
\hline
\end{tabular}

4.2 lentelè. Dviekranių meandrinių mikrojuostelinių vèlinimo linijų modelių vèlinimo trukmès pokyčiai tiesios perdavimo linijos atžvilgiu

Table 4.2. Delay time variations of two shielded microstrip delay line in respect of straight transmission line

\begin{tabular}{|c|c|c|c|}
\hline \multirow{2}{*}{$\begin{array}{c}\text { Linijos } \\
\text { modelis }\end{array}$} & \multicolumn{3}{|c|}{ Vèlinimo trukmės pokytis, \% } \\
\cline { 2 - 4 } & $\begin{array}{c}\text { CST Microwave }_{\text {Studio }^{\circledR}(f=4 \mathrm{GHz})} \\
\text { Perdavimo linija }^{\text {Sonnet }}{ }^{\circledR} \\
(f=4 \mathrm{GHz})\end{array}$ & $\begin{array}{c}\text { Straipsnis } \\
\text { (Rubin, Singh 2000) }^{(}\end{array}$ \\
\hline DMMVL-60 & $-1,16$ & 0 & 0 \\
\hline DMMVL-30 & $-1,24$ & $-1,4$ & $-0,81$ \\
\hline DMMVL-15 & $-2,8$ & $-2,5$ & $-0,92$ \\
\hline DMMVL-10 & $-5,5$ & $-4,7$ & $-2,8$ \\
\hline
\end{tabular}


Iš 4.3 lentelejje pateiktų rezultatų matyti, kad esant žemiesiems dažniams iki $200 \mathrm{MHz}$ Sonnet ${ }^{\circledR}$ programų paketu gautų vèlinimo trukmių santykinis skirtumas su (Rubin, Singh 2000) darbe pateiktais duomenimis skiriasi $5 \%$ tiesios perdavimo linijos atveju ir daugiau nei $115 \%$ meandrinių vèlinimo linijų atveju.

4.3 lentelè. Dviekranių meandrinių mikrojuostelinių vèlinimo linijų modelių konstrukciniai parametrai

Table 4.3. Structural parameters of two shielded microstrip delay line models

\begin{tabular}{|c|c|c|c|c|c|c|c|}
\hline $\begin{array}{c}\text { Linijos } \\
\text { modelis }\end{array}$ & $S / h_{1}$ & $L / h_{1}$ & $W / h_{1}$ & $2 A / h_{1}$ & $h_{2} / h_{1}$ & $h_{1}, \mathrm{~mm}$ & $\varepsilon_{\mathrm{r}}$ \\
\cline { 1 - 3 } DMMVL-60 & 12,6 & 13,33 & & & & & \\
\cline { 1 - 3 } DMMVL-30 & 5,93 & 6,67 & \multirow{2}{*}{0,73} & 20,81 & 2,53 & 0,114 & 3,9 \\
\cline { 1 - 4 } DMML-15 & 2,6 & 3,33 & & & & & \\
\hline DMMVL-10 & 1,49 & 2,22 & & & & & \\
\hline
\end{tabular}

4.4 lentelė. Dviekranių meandrinių mikrojuostelinių vèlinimo linijų modelių, sudarytų CST Microwave Studio ${ }^{\circledR}$ ir Sonnet ${ }^{\circledR}$ programu paketuose, vèlinimo trukmès vertes, apskaičiuotos žemuosiuose ir aukštuosiuose dažniuose

Table 4.4. Delay time values of two shielded microstrip delay line, which are created in CST Microwave Studio ${ }^{\circledR}$ and Sonnet ${ }^{\circledR}$ program packages, calculated in lower and upper frequencies

\begin{tabular}{|c|c|c|c|c|c|}
\hline \multirow{3}{*}{$\begin{array}{l}\text { Linijos } \\
\text { modelis }\end{array}$} & \multicolumn{5}{|c|}{ Vèlinimo trukmè, ps } \\
\hline & \multicolumn{2}{|c|}{$\begin{array}{l}\text { CST Microwave } \\
\text { Studio }^{\circledR}\end{array}$} & \multicolumn{2}{|c|}{ Sonnet $^{\circledR}$} & \multirow{2}{*}{$\begin{array}{c}\text { Straipsnis } \\
\text { (Rubin, Singh 2000) }\end{array}$} \\
\hline & $200 \mathrm{MHz}$ & $4 \mathrm{GHz}$ & $200 \mathrm{MHz}$ & $4 \mathrm{GHz}$ & \\
\hline Perdavimo linija & 925,0 & 925,3 & 943,8 & 923,3 & 925,3 \\
\hline DMMVL- 60 & 913,7 & 914,6 & 929,0 & 910,0 & 917,8 \\
\hline DMMVL-30 & 912,8 & 913,8 & 928,4 & 909,4 & 916,8 \\
\hline DMMVL- 15 & 897,1 & 899,6 & 918,5 & 899,8 & 899,8 \\
\hline D M M V L - 10 & 869,3 & 874,1 & 893,9 & 879,6 & 873,8 \\
\hline
\end{tabular}

Kai dažnis didesnis nei $200 \mathrm{MHz}$, santykinis skirtumas nedidesnis nei $3 \%$ ir, dažniui pasiekus $300 \mathrm{MHz}$, - skirtumas sumažeja iki $2 \%$ ir toks išlieka likusiame dažnių ruože. CST Microwave studio ${ }^{\circledR}$ programų paketu gauti rezultatai tikslesni visame dažnių ruože ir santykinis skirtumas atitinkamai neviršija 2 \% (kai 


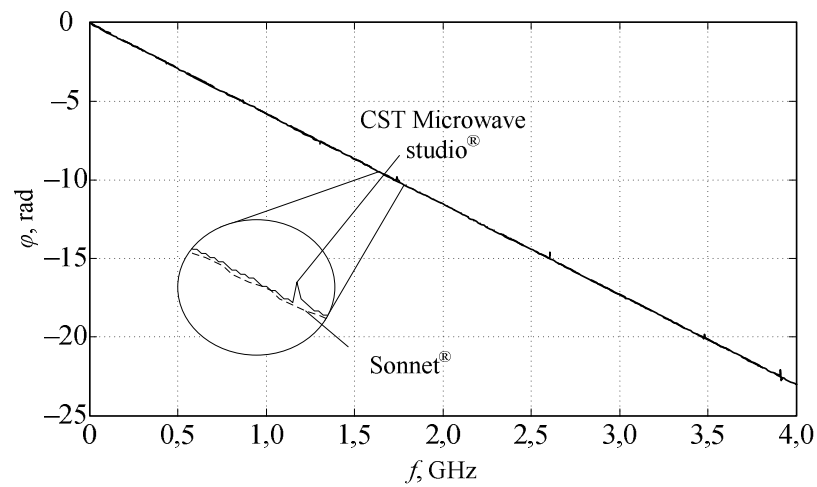

4.8 pav. Fazės iškraipymų dažninès priklausomybės gautos skirtingais programų paketais

Fig. 4.8. Phase distortion frequency dependency of program package

dažnis lygus $1 \mathrm{MHz}$ ) ir $1 \%$ (kai dažnis lygus $4 \mathrm{GHz}$ ). İèjimo ir išèjimo signalų fazių skirtumu priklausomybès nuo dažnio, gautos Sonnet ${ }^{\circledR}$ ir CST Microwave Studio ${ }^{\circledR}$ programų paketais, pateiktos 4.8 paveiksle. CST Microwave Studio ${ }^{\circledR}$ programu paketu gauti signalo fazių skirtumo iškraipymai, tai matyti 4.8 paveiksle, - linijos analizès modelio netolygumas. Šie netolygumai sumažeja padidinus tinklelio ląstelių skaičių, tačiau atitinkamai pailgèja ir skaičiavimo laikas. Atliekant meandrinių linijų modeliavimus abejų paketų skaičiavimo trukmès panašios $\sim 1$ val.

Atliktų keturių skirtingo žingsnio MMVL vèlinimo laikų skaičiavimų, taikant daugialaidžių linijų metodą, ir lyginimų su programų paketais rezultatai pateikti 4.5 lentelèje. Kadangi nagrinejjamos struktūros yra homogenineje aplinkoje (signalinius meandrinès linijos laidininkus gaubia vienodas dielektrikas), todèl bangos skaičius tokioje aplinkoje gaunamas pagal išraišką:

$$
k=\frac{\operatorname{arctg}\left[\sqrt{\left.\frac{Y(\theta+\pi)}{Y(\theta)}\right]} \cdot \operatorname{tg} \frac{\theta}{2}\right.}{A \cdot \sqrt{\varepsilon_{\mathrm{r}}}},
$$

čia $A$ - pusè meandro ilgio; $Y(\theta)$ ir $Y(\theta+\pi)$ - daugialaidès mikrojuostelinès linijos banginiai laidumai, esant fazių tarp įtampos ar srovès gretimuose linijos laidininkuose skirtumui $\theta$ ir $\theta+\pi$ atitinkamai. Šie laidumai randami taikant išraiškas:

$$
Y(\theta)=Y_{\mathrm{c}} \cos ^{2} \frac{\theta}{2}+Y_{\pi} \sin ^{2} \frac{\theta}{2},
$$




$$
Y(\theta+\pi)=Y_{\mathrm{c}} \sin ^{2} \frac{\theta}{2}+Y_{\pi} \cos ^{2} \frac{\theta}{2},
$$

čia $\theta$ - sklindančios bangos fazinis poslinkis tarp dviejų gretimų daugialaidès linijos laidininkų; $Y_{\mathrm{c}}$ ir $Y_{\pi}$-daugialaidès mikrojuostelinès linijos banginiai laidumai, esant atitinkamai lyginiam ir nelyginiam sužadinimui.

Mikrojuostelinès daugialaidès linijos banginiai laidumai, esant lyginiam ir nelyginiam sužadinimui, apskaičiuoti naudojantis baigtinių skirtumų metodu ir susietujų matricų būdu MATLAB ${ }^{\circledR}$ terpeje. Gautus lyginio ir nelyginio sužadinimo banginius laidumus įstačius i (4.4) ir (4.5) išraiškas, o šias i (4.3) - apskaičiuoti bangos skaičiai esant skirtingiems bangos fazinių skirtumams tarp dviejų gretimų daugialaidès linijos laidininkų. Fazès ir dažnio priklausomybè buvo rasta panaudojus išraišką:

$$
f=\frac{k \cdot c_{0}}{2 \pi} .
$$

Gauti skaičiavimo rezultatai pateikti 4.5 lenteleje. Joje pateikti rezultatai: meandro dalies apskaičiuotos daugialaidžių linijų metodu ir tiesaus laidininko teorinès dalies, šių dalių sumos bei (Rubin, Singh 2000) darbe pateiktų vèlinimo laikų santykinis skirtumas. Kaip matyti iš rezultatų, didejjant tarpui tarp gretimų signalinių laidininkų, santykinis skirtumas taip pat didejja. Šis padidejimas vyksta dèl vèlinimo laiko neįvertinimo tarp gretimų signalinių laidininkų modelyje, grịstame daugialaidès linijos metodu. Laikoma, kad banga sklinda toje dalyje akimirksniu ir, didejant atstumams tarp gretimų signalinių laidininkų, santykinis skirtumas tik dideja. 4.6 lenteleje pateikti rezultatai įvertinus šiuos atstumus ir santykinis skirtumas šiuo atveju neviršija 7 \%.

4.5 lentelè. Dviekranių meandrinių mikrojuostelinių vèlinimo linijų modelių, sudarytų pagal daugialaidžių linijų metodą, vèlinimo trukmès apskaičiuotos vertès

Table 4.5. Delay time values of two shielded microstrip delay line models, which are created by multiconductor line method

\begin{tabular}{|c|c|c|c|c|}
\hline \multirow{2}{*}{$\begin{array}{c}\text { Linijos } \\
\text { modelis }\end{array}$} & \multicolumn{2}{|c|}{ Vèlinimo trukmé,ps } & \multicolumn{2}{c|}{$\begin{array}{c}\text { Santykinis skirtumas specializuotuc } \\
\text { programų paketų atžvilgiu }{ }^{*} \%\end{array}$} \\
\cline { 2 - 5 } & $f=200 \mathrm{MHz}$ & $f=4 \mathrm{GHz}$ & $f=200 \mathrm{MHz}$ & $f=4 \mathrm{GHz}$ \\
\hline DMMVL-60 & 848,9 & 842,7 & $-7,86$ & $-7,63$ \\
\hline DMMVL-30 & 913,3 & 907,2 & $-0,79$ & $-0,49$ \\
\hline DMMVL-15 & 933,6 & 928,2 & 2,84 & 3,16 \\
\hline DMMVL-10 & 924,9 & 920,6 & 4,91 & 4,99 \\
\hline
\end{tabular}


4.6 lentelè. Daugialaidžių linijų metodu gauti rezultatai, ịvertinus atstumus tarp gretimų laidininku

Table 4.6. Calculation results of multiconductor line method, when taking into account distance between conductors

\begin{tabular}{|c|c|c|c|c|}
\hline \multirow{2}{*}{$\begin{array}{c}\text { Linijos } \\
\text { modelis }\end{array}$} & \multicolumn{2}{|c|}{ Vèlinimo trukmé, ps } & \multicolumn{2}{c|}{$\begin{array}{c}\text { Santykinis skirtumas specializuotų } \\
\text { programų paketų atzilgiu*, \% }\end{array}$} \\
\cline { 2 - 5 } & $f=200 \mathrm{MHz}$ & $f=4 \mathrm{GHz}$ & $f=200 \mathrm{MHz}$ & $f=4 \mathrm{GHz}$ \\
\hline DMMVL-60 & 972,2 & 966,0 & 5,52 & 5,89 \\
\hline DMMVL-30 & 971,4 & 965,2 & 5,52 & 5,88 \\
\hline DMMVL-15 & 959,0 & 953,6 & 5,64 & 5,99 \\
\hline DMMVL-10 & 939,5 & 935,1 & 6,57 & 6,65 \\
\hline
\end{tabular}

Pastabos: ${ }^{*}$ CST Microwave Studio ${ }^{\circledR}$ ir Sonnet ${ }^{\circledR}$ programu paketu gautos vertes suvidurkintos.

\subsection{Tolygios būdingosios varžos meandrinès mikrojuostelinès vẻlinimo linijos sudarymas ir tyrimas}

Poskyryje nagrinejami meandrinès mikrojuostelinès vèlinimo linijos būdingosios varžos netolygumai $\left(Z_{\mathrm{B} i} \neq Z_{\mathrm{B} j}\right.$, čia $i$ ir $j$ yra MMVL strypų numeriai, $\left.i \neq j\right)$, kurie atsiranda dèl vienodo visu meandro strypų pločio (4.9 pav.). Aptariama daugialaidès mikrojuostelinès linijos (DML) parametru netolygumo ịtakos MMVL dažninėms charakteristikoms tyrimo metodika. Pasiūlytu algoritmu sintezuojamos tolygios būdingosios varžos $\left(Z_{\mathrm{B} i}=Z_{\mathrm{B} j}\right)$ DML. Remiantis sintezuotųjų DML konstrukciniais parametrais Sonnet ${ }^{\circledR}$ elektrodinaminių įtaisų modeliavimo terpeje sukuriami atitinkamu MMVL kompiuteriniai modeliai ir randamos jų dažninès charakteristikos. Apskaičiuotos MMVL charakteristikos lyginamos su charakteristikomis analogiškų vèlinimo linijų, kurių visų laidininkų pločiai vienodi, t. y. pasireiškia elektromagnetinio lauko sklaida galuose, o atitinkamų DML elektriniai parametrai - netolygūs.

\subsubsection{Tolygios būdingosios varžos meandrinès mikrojuostelinès linijos modelis}

Remiantis daugialaidžių linijų metodu, MMVL modeliuojama pagal DML, kurios struktūra pavaizduota 4.10 paveiksle, a. MMVL ir atitinkamos DML konstrukciniai parametrai yra šie: pagrindo storis $h$ ir santykinė dielektrinè skvarba $\varepsilon_{\mathrm{r}}$, bei laidininkų pločiai $W$ ir tarpai tarp jų $S$. Sudarant meandrinès mikrojuostelinès 


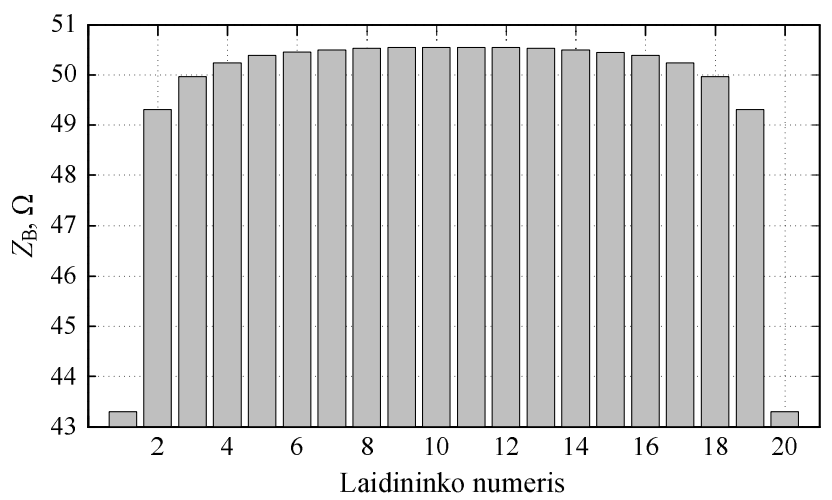

4.9 pav. Mikrojuostelinès meandrinès vėlinimo linijos, grịstos periodine daugialaidè mikrojuosteline linija, strypų būdingoji varža, kai $\varepsilon_{\mathrm{r}}=9,6$;

$h=0,5 \mathrm{~mm} ; W=0,6 \mathrm{~mm} ; S=0,5 \mathrm{~mm} ; 2 A=20 \mathrm{~mm} ; N=20$

Fig. 4.9. Conductors characteristic impedance of meander microstrip delay line based on periodic multiconductor microstrip line, when $\varepsilon_{\mathrm{r}}=9.6$; $h=0.5 \mathrm{~mm} ; W=0.6 \mathrm{~mm} ; S=0.5 \mathrm{~mm} ; 2 A=20 \mathrm{~mm} ; N=20$
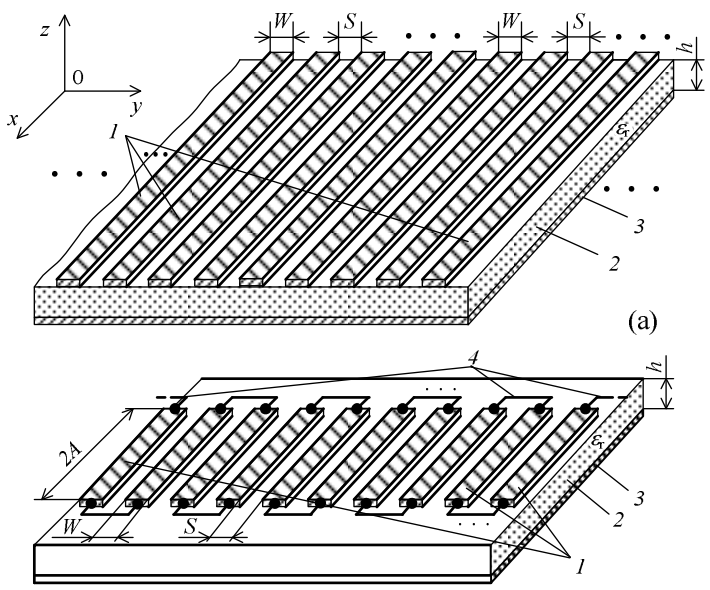

(b)

4.10 pav. Daugialaidès mikrojuostelinès linijos sandara (a) ir jos pagrindu sudarytos meandrinès mikrojuostelinès vėlinimo linijos modelis (b); čia 1 - linijos laidininkai, 2 - dielektrinis pagrindas, 3 - ekranas, 4 - meandro strypu jungtys

Fig. 4.10. The generalized structure of the microstrip multiconductor line (a), and microstrip meander structure (b), where 1 - conductors of the line; 2 - a dielectric substrate; 3 - a reference conductor; 4 - connectors of the meander strips 
linijos matematinị modeli, daugialaidè mikrojuostelinè linija laikoma begaline $x$ ir $y$ kryptimis. Meandrinè struktūra sudaroma iš DML atskiriant $2 A$ ilgio jos dali $x$ kryptimi, ir atitinkamai sujungiant strypu galus (4.10 pav., b).

Siekiant suderinti bet kokią perdavimo liniją, tarp jų ir MMVL, su likusiu signalo perdavimo traktu, MMVL ir perdavimo trakto būdingosios varžos turi būti vienodos. Daugialaide linija grịstos MMVL meandro strypų būdingosios varžos yra laikomos vienodomis, ir strypu pločiai taip pat vienodi (4.10 pav., a). Tačiau praktiškai gaminamų MMVL strypų skaičius yra baigtinis, todèl elektrinio lauko struktūra ties galiniais strypais yra netolygi, dèl to galinių strypų būdingosios varžos skiriasi nuo linijos viduryje esančių strypų būdingujjų varžų (4.9 pav.). Tokiu atveju bendras signalo perdavimo traktas - nesuderintas.

\subsubsection{Tolygios būdingosios varžos meandrinès mikrojuostelinès linijos modelio tyrimas}

Atliekant tolygios būdingosios varžos MMVL tyrimus, nagrinejjamos sklaidos parametrų dažninès priklausomybès. MMVL sklaidos $S_{21}$ parametro dažninè priklausomybè pateikta 4.11 paveiksle. Pagal $S_{21}$ parametro modulio dažninę priklausomybę matyti, kad MMVL pasireiškia rezonansas. Šio rezonanso dažnis susijęs su signalo, sklindančio MMVL bangos ilgiu ir konstrukciniais parametrais, ir apytiksliai išreiškiamas tokia formule:

$$
f_{k}=\frac{\mathrm{c}_{0} k}{\sqrt{\varepsilon_{\mathrm{r} \mathrm{ef}}}(2 \cdot 2 A+S)},
$$

čia $c_{0}$ - šviesos greitis vakuume, $k$-rezonanso eilès numeris, $\varepsilon_{\text {ref }}-$ DML efektyvioji dielektrinè skvarba, $2 A$ ir $S$ - meandro topologijos dydžiai (4.10 pav., b). Tolygios būdingosios varžos MMVL rezonansas yra šiek tiek pasislinkęs aukštesniujjų dažnių link (tokiu būdu praplatejja ir pralaidumo juosta), lyginant su atitinkama netolygios būdingosios varžos MMVL. Šis rezonanso poslinkis paaiškinamas tuo, kad tolygios būdingosios varžos MMVL siauresnių galinių strypų efektyvioji dielektrinè skvarba yra mažesne, jais sklindančios elektromagnetinės bangos greitis yra didesnis, todèl rezonanso dažnis, apskaičiuotas pagal (4.7) aukštesnis.

Pažymėtina, kad medžiagų, naudojamų gaminant realias MMVL, laidumo ir dielektriniai nuostoliai yra nykstamai maži, todèl tokių linijų pralaidumo juosta yra vertinama pagal fazès charakteristikos iškraipymus, o ne pagal amplitudès. Pavyzdžiui, tolygios būdingosios varžos MMVL pralaidumo juosta, nustatyta pagal amplitudès dažninę charakteristiką ( $S_{21}$ modulis) (4.11 pav., a) lygi $2,38 \mathrm{GHz}$, o nustatyta pagal fazès dažninę charakteristiką $\left(S_{21}\right.$ argumentas) (4.11 pav., b), tik 1,05 GHz. Todèl, tolimesnèje MMVL analizejje pralaidumo 
juosta bus laikomas dažnių ruožas, kuriame fazès charakteristikos nuokrypis nuo idealios ne didesnis nei $0,5 \mathrm{rad}$.

Vèlinimo trukmè $t_{\mathrm{d}}$ ir pralaidumo juostos plotis $\Delta F$ yra pagrindinès MMVL charakteristikos. Pagrindo dielektrinè skvarba $\varepsilon_{\mathrm{r}}$, meandro strypų skaičius $N$ ir jų ilgis $2 A$ labiausiai veikia minètąsias charakteristikas. Taip pat paminètina, kad vèlinimo trukmè $t_{\mathrm{d}}$ ir juostos plotis $\Delta F$ yra atvirkščiai proporcingi, t. y. keičiant MMVL konstrukcinius parametrus ir siekiant padidinti vèlinimo trukmę, pralaidumo juosta siaureja, atvirkštinis teiginys taip pat teisingas. Todèl, siekiant ịvertinti konstrukcinių parametrų įtaką MMVL charakteristikoms, naudotinas integruotas vèlinimo linijų įvertis - vadinamasis $D$-faktorius, kuris išreiškiamas kaip vèlinimo trukmès ir pralaidumo juostos sandauga:
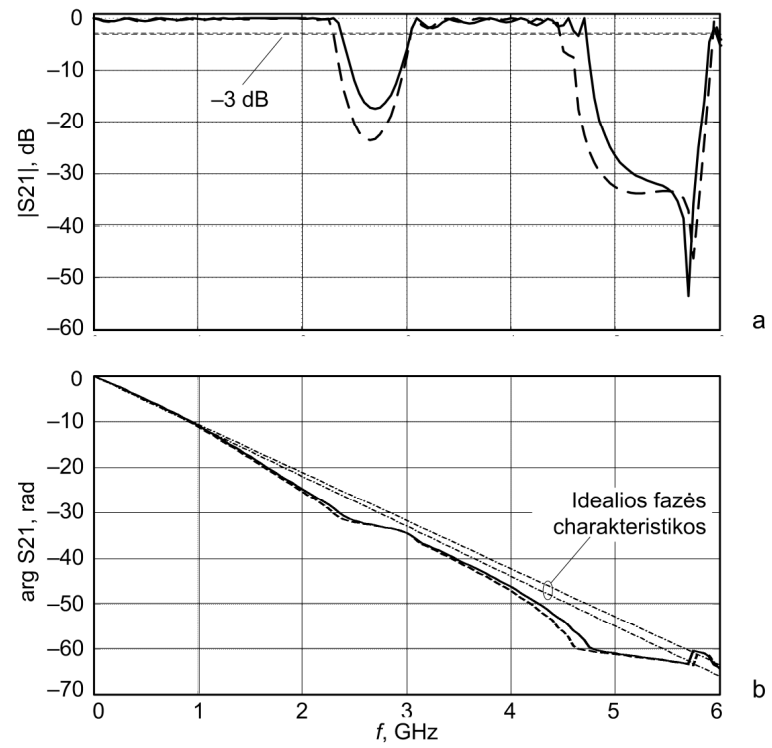

4.11 pav. Meandrinès mikrojuostelinès vėlinimo linijos perdavimo charakteristikos ( $S_{21}$ parametro) (a) - modulis, (b) - argumentas (fazè), kai $\varepsilon_{\mathrm{r}}=9,6 ; h=0,5 \mathrm{~mm} ; 2 A=20 \mathrm{~mm} ; N=10$. Vientisos kreivès - tolygios būdingosios varžos; brūkšninès kreivès - netolygios būdingosios varžos meandrinès mikrojuostelinès vèlinimo linijos

Fig. 4.11. Magnitude (a) and phase (b) response of parameter $S_{21}$ of the meander microstrip delay line which design parameters are following: $\varepsilon_{\mathrm{r}}=9.6, h=0.5 \mathrm{~mm}, 2 A=20 \mathrm{~mm}, N=10$. Solid curves corresponds the uniform impedance, and dashed ones corresponds the non-uniform impedance of meander microstrip delay line. 


$$
D_{(\mathrm{u}, \mathrm{u}-\mathrm{n})}=t_{\mathrm{d}(\mathrm{u}, \mathrm{u}-\mathrm{n})} \cdot \Delta F_{(\mathrm{u}, \mathrm{u}-\mathrm{n})},
$$

čia apatinis indeksas u (angl. uniform) reiškia tolygiu parametrų MMVL (t. y. tolygios būdingosios varžos), indeksas n-u - netolygiu (angl. non-uniform) parametru MMVL.

Pirmojoje tyrimų dalyje nagrinejjama MMVL strypų būdingosios varžos suvienodinimo įtaka MMVL charakteristikoms. Tolygios ir netolygios būdingosios varžos MMVL charakteristikų priklausomybè nuo linijos konstrukcinių parametru pateikta 4.7-4.10 lentelèse. Šiose lentelèse taip pat pateikiami santykiniai skirtumai tarp tolygios ir netolygios būdingosios varžos MMVL charakteristikų. Vèlinimo trukmès santykinis skirtumas:

$$
\delta t_{\mathrm{d}}=\frac{t_{\mathrm{d}(\mathrm{u})}-t_{\mathrm{d}(\mathrm{n}-\mathrm{u})}}{t_{\mathrm{d}(\mathrm{n}-\mathrm{u})}} 100 \%,
$$

čia $t_{\mathrm{d}(\mathrm{u})}$ - tolygios būdingosios varžos MMVL vèlinimo trukmè, $t_{\mathrm{d}(\mathrm{n}-\mathrm{u})}-$ netolygios būdingosios varžos MMVL vèlinimo trukmè. Pralaidumo juostos santykinis skirtumas:

$$
\delta \Delta F=\frac{\Delta F_{(\mathrm{u})}-\Delta F_{(\mathrm{n}-\mathrm{u})}}{\Delta F_{(\mathrm{n}-\mathrm{u})}} 100 \%,
$$

čia $\Delta F_{(\mathrm{u})}$ - tolygios būdingosios varžos MMVL pralaidumo juosta, $\Delta F_{(\mathrm{n}-\mathrm{u})}-$ netolygios būdingosios varžos MMVL pralaidumo juosta. $D$-faktoriaus santykinis skirtumas:

$$
\delta D=\frac{D_{(\mathrm{u})}-D_{(\mathrm{n}-\mathrm{u})}}{D_{(\mathrm{n}-\mathrm{u})}} 100 \%,
$$

čia $D_{(\mathrm{u})}$ - tolygios būdingosios varžos MMVL $D$-faktorius, $D_{(\mathrm{n} \text {-u })}-$ netolygios būdingosios varžos MMVL $D$-faktorius.

4.11 paveikslo ir 4.7-4.10 lenteliu analizė atskleidžia, kad esant analogiškiems konstrukciniams parametrams, tolygios būdingosios varžos MMVL vèlinimo trukmé $t_{\mathrm{d}(\mathrm{u})}$ visais atvejais mažesnè nei netolygios būdingosios varžos MMVL $t_{\mathrm{d}(\mathrm{n}-\mathrm{u})}$. Šs skirtumas atsiranda dèl mažesnès tolygios būdingosios varžos MMVL siauresnių galinių strypų efektyviosios dielektrinès skvarbos ties kuriais, kaip pasekmè, elektromagnetinė banga sklinda greičiau. 


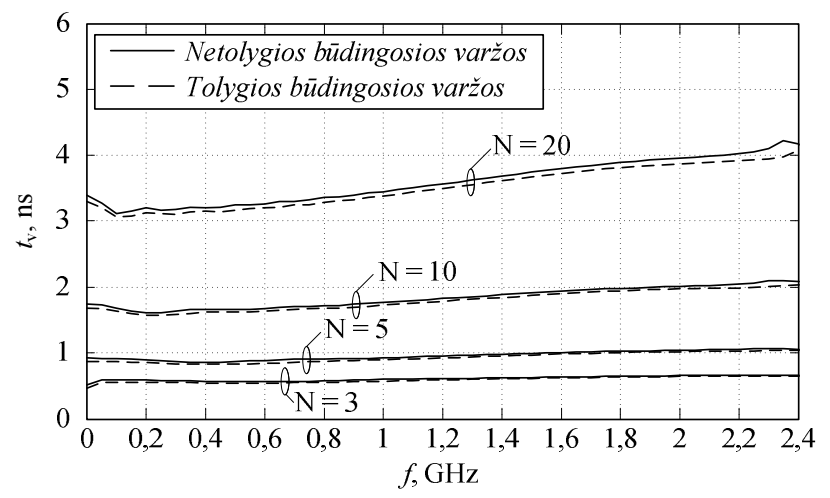

4.12 pav. Meandrinès mikrojuostelinès vèlinimo linijos vèlinimo trukmès priklausomybė nuo dažnio ir meandro strypų skaičiaus, kai $\varepsilon_{\mathrm{r}}=9,6$;

$$
h=0,5 \mathrm{~mm} ; 2 A=20 \mathrm{~mm}
$$

Fig. 4.12. Delay time dependence on frequency of the meander microstrip delay line and number of meander strips, which design parameters are following: $\varepsilon_{\mathrm{r}}=9.6, h=0.5 \mathrm{~mm}, 2 A=20 \mathrm{~mm}$

4.7 lentelè. Tolygios ir netolygios būdingosios varžos meandrinès mikrojuostelinès vèlinimo linijos charakteristikų priklausomybè nuo meandro strypų skaičiaus, kai $\varepsilon_{\mathrm{r}}=9,6 ; h=0,5 \mathrm{~mm} ; 2 A=20 \mathrm{~mm}$

Table 4.7. Dependence of characteristics of the uniform and non-uniform characteristic impedance meander microstrip delay line on number of the meander strips, when $\varepsilon_{\mathrm{r}}=9.6 ; h=0.5 \mathrm{~mm} ; 2 A=20 \mathrm{~mm}$

\begin{tabular}{|c|c|c|c|c|c|}
\hline \multirow{2}{*}{ MMVL charakteristika } & \multicolumn{5}{|c|}{ Meandro strypu skaičius $N$} \\
\cline { 2 - 6 } & 3 & 5 & 10 & 20 & 40 \\
\hline$t_{\mathrm{d}(\mathrm{u})}, \mathrm{ns}$ & 0,46 & 0,87 & 1,68 & 3,3 & 6,54 \\
\hline$t_{\mathrm{d}(\mathrm{n}-\mathrm{u})}, \mathrm{ns}$ & 0,52 & 0,92 & 1,75 & 3,4 & 6,69 \\
\hline$\delta t_{\mathrm{d}}, \%$ & -11 & -6 & $-3,8$ & $-2,9$ & $-2,2$ \\
\hline$\Delta F_{(\mathrm{u})}, \mathrm{GHz}$ & 1,3 & 1,2 & 1,05 & 0,3 & 0,14 \\
\hline$\Delta F_{(\mathrm{n}-\mathrm{u})}, \mathrm{GHz}$ & 1,55 & 1,3 & 1,15 & 0,25 & 0,13 \\
\hline$\delta F, \%$ & -16 & -8 & -9 & 20 & 7,7 \\
\hline$D_{(\mathrm{u})}$ & 0,598 & 1,044 & 1,764 & 0,99 & 0,916 \\
\hline$D_{(\mathrm{n}-\mathrm{u})}$ & 0,806 & 1,196 & 2,013 & 0,85 & 0,87 \\
\hline$\delta D, \%$ & -26 & -13 & -12 & 16 & 5,3 \\
\hline
\end{tabular}


MMVL, sudarytos iš didesnio skaičiaus strypu $N$, vèlinimo trukmè, beveik proporcingai $N$, yra didesnè (4.7 lentelè). Tuo tarpu MMDL turinčios daugiau strypų pralaidumo juosta yra ženkliai siauresnè. Atlikti tyrimai parodè, kad strypų būdingujų varžų suvienodinimas duoda teigiamą efektą tik esant meandrinèje linijoje didesniam strypų skaičiui $N$. 4.7 lenteleje matyti, kad, kai $N=20$, tolygios būdingosios varžos MMVL pralaidumo juosta yra $20 \%$ platesnè, nei analogiškos netolygios būdingosios varžos MMVL. Tolygios būdingosios varžos MMVL $D$-faktorius šiuo atveju taip pat didesnis $16 \%$ nei atitinkamos netolygios būdingosios varžos MMVL. Iš 4.12 paveiksle pateiktų priklausomybių matyti, kad vèlinimo trukmès priklausomybè po būdinguju varžų suvienodinimo išlieka panaši, tačiau elektromagnetinè banga ties tolygios būdingosios varžos MMVL sklinda iki 7 \% greičiau.

MMVL vèlinimo trukmé taip pat beveik proporcingai didèja, didinant meandro strypų aukšti $2 A$ (4.8 lentelè). Tačiau pralaidumo juosta šiuo atveju beveik proporcingai mažèja. Iš 4.8 lentelès matyti, kad tolygios būdingosios varžos MMVL pralaidumo juosta daugeliu atveju didesnè nei netolygios būdingosios varžos MMVL. Tik esant itin dideliam meandro strypu aukščiui $(2 A=40 \mathrm{~mm}$, arba $2 A / h=80)$, t. y. kuomet silpnejja meandro kraštų netolygumo itaka, tolygios ir netolygios būdingosios varžos MMVL pralaidumo juostos pločiai sutampa. Tolygios būdingosios varžos MMVL $D$-faktorius $16 \%$ didesnis, nei netolygios būdingosios varžos MMVL (išskyrus minètą atvejị, kai $2 A / h=$ 80). Iš MMVL amplitudès perdavimo charakteristikos (4.13 pav.) matyti, kad

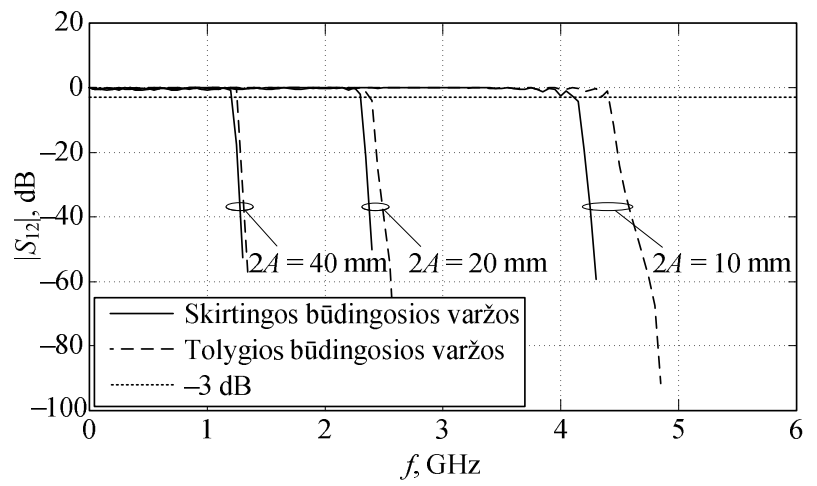

4.13 pav. Meandrinės mikrojuostelinės vèlinimo linijos perdavimo charakteristikos ( $S_{12}$ parametro) modulio kitimas kintant meandro strypu aukščiui, kai $\varepsilon_{\mathrm{r}}=9,6 ; h=0,5 \mathrm{~mm} ; N=20$

Fig. 4.13. Magnitude response of parameter $S_{12}$ with different height meander strips of the meander microstrip delay line, which design parameters are following: $\varepsilon_{\mathrm{r}}=9.6 ; h=0.5 \mathrm{~mm} ; N=20$ 
4.8 lentelè. Tolygios ir netolygios būdingosios varžos meandrinès mikrojuostelinès vèlinimo linijos charakteristikų priklausomybè nuo meandro strypų aukščio, kai $\varepsilon_{\mathrm{r}}=9,6$; $h=0,5 \mathrm{~mm} ; N=20$

Table 4.8. Dependence of characteristics of the uniform and non-uniform characteristic impedance meander microstrip delay line on height of the meander strips, when $\varepsilon_{\mathrm{r}}=9.6 ; h=0.5 \mathrm{~mm} ; N=20$

\begin{tabular}{|c|c|c|c|}
\hline \multirow{2}{*}{ MMVL charakteristika } & \multicolumn{3}{|c|}{ Meandro strypu ilgis $2 A, \mathrm{~mm}$} \\
\cline { 2 - 4 } & 10 & 20 & 40 \\
\hline$t_{\mathrm{d}(\mathrm{u})}, \mathrm{ns}$ & 1,8 & 3,3 & 6,3 \\
\hline$t_{\mathrm{d}(\mathrm{n}-\mathrm{u})}, \mathrm{ns}$ & 1,89 & 3,4 & 6,4 \\
\hline$\delta t_{\mathrm{d}}, \%$ & $-4,5$ & $-2,9$ & -2 \\
\hline$\Delta F_{(\mathrm{u})}, \mathrm{GHz}$ & 0,55 & 0,3 & 0,15 \\
\hline$\Delta F_{(\mathrm{n}-\mathrm{u})}, \mathrm{GHz}$ & 0,45 & 0,25 & 0,15 \\
\hline$\delta F, \%$ & 22 & 20 & 0 \\
\hline$D_{(\mathrm{u})}$ & 0,99 & 0,99 & 0,945 \\
\hline$D_{(\mathrm{n}-\mathrm{u})}$ & 0,851 & 0,85 & 0,96 \\
\hline$\delta D, \%$ & 16,4 & 16 & $-1,6$ \\
\hline
\end{tabular}

4.9 lentelè. Tolygios ir netolygios būdingosios varžos meandrinès mikrojuostelinės vèlinimo linijos charakteristiku priklausomybè nuo dielektrinio pagrindo skvarbos, kai $h=0,5 \mathrm{~mm} ; 2 A=20 \mathrm{~mm} ; N=20$

Table 4.9. Dependence of characteristics of the uniform and non-uniform characteristic impedance meander microstrip delay line on permittivity of the dielectric substrate, when at $h=0.5 \mathrm{~mm} ; 2 A=20 \mathrm{~mm} ; N=20$

\begin{tabular}{|c|c|c|c|}
\hline \multirow{2}{*}{ MMVL charakteristika } & \multicolumn{3}{|c|}{ Dielektrinio pagrindo skvarba, $\varepsilon_{\mathrm{r}}$} \\
\cline { 2 - 4 } & 4,5 & 9,6 & 16 \\
\hline$t_{\mathrm{d}(\mathrm{u})}, \mathrm{ns}$ & 2,5 & 3,3 & 4,12 \\
\hline$t_{\mathrm{d}(\mathrm{n}-\mathrm{u})}, \mathrm{ns}$ & 2,59 & 3,4 & 4,2 \\
\hline$\delta t_{\mathrm{d}}, \%$ & $-3,3$ & $-2,9$ & $-1,9$ \\
\hline$\Delta F_{(\mathrm{u})}, \mathrm{GHz}$ & 1,25 & 0,3 & 0,2 \\
\hline$\Delta F_{(\mathrm{n}-\mathrm{u})}, \mathrm{GHz}$ & 0,55 & 0,25 & 0,2 \\
\hline$\delta F, \%$ & 127 & 20 & 0 \\
\hline$D_{(\mathrm{u})}$ & 3,125 & 0,99 & 0,824 \\
\hline$D_{(\mathrm{n}-\mathrm{u})}$ & 1,425 & 0,85 & 0,84 \\
\hline$\delta D, \%$ & 120 & 16 & $-1,9$ \\
\hline
\end{tabular}


didinant meandro aukšti $2 A$ pralaidumo juosta tolygios būdingosios varžos MMVL, nustatyta iš dažnio amplitudès charakteristikos, visuomet yra platesnè nei skirtingos būdingosios varžos MMVL.

Vèlinimo trukmé gali būti didinama, nedidinant MMVL gabaritu, parenkant didesnès dielektrinès skvarbos pagrindą (4.9 lentelè). Svarbu paminèti, kad padidinus pagrindo skvarbą apie $70 \%(16 / 9,6 \cong 1,7)$, paliekant kitus konstrukcinius parametrus pastoviais, vèlinimo trukmè padideja tik $25 \%(4,12 / 3,3 \cong 1,24)$, tuo tarpu pralaidumo juostos plotis sumažèja apie $50 \%(0,55 / 0,25 \cong 2,2)$. Kai kurios tolygios būdingosios varžos MMVL charakteristikos šiuo atveju keičiasi daugiau neigiama linkme, lyginant su netolygios būdingosios varžos MMVL. Pavyzdžiui, didinant pagrindo skvarbą, kaip anksčiau minètame pavyzdyje, $70 \%$, tolygios būdingosios varžos $D$-faktorius mažeja $20 \%(0,99 / 0,824 \cong 1,2)$, o netolygios būdingosios varžos MMVL $D$-faktorius išlieka beveik nepakitęs.

4.10 lentelè. Tolygios ir netolygios būdingosios varžos meandrinès mikrojuostelinès vèlinimo linijos charakteristiku priklausomybė nuo tarpo tarp meandro strypų dydžio, kai $\varepsilon_{\mathrm{r}}=9,6 ; h=0,5 \mathrm{~mm} ; 2 A=20 \mathrm{~mm} ; N=20$

Table 4.10. Dependence of characteristics of the meander microstrip delay line on space between meander strips at $\varepsilon_{\mathrm{r}}=9.6 ; h=0.5 \mathrm{~mm} ; 2 A=20 \mathrm{~mm} ; N=20$

\begin{tabular}{|c|c|c|c|c|}
\hline \multirow{2}{*}{ MMVL charakteristika } & \multicolumn{4}{|c|}{ Tarpas tarp meandro strypu $S, \mathrm{~mm}$} \\
\cline { 2 - 5 } & 0,25 & 0,5 & 1,0 & 2,0 \\
\hline$t_{\mathrm{d}(\mathrm{u})}, \mathrm{ns}$ & 3,11 & 3,3 & 3,56 & 3,78 \\
\hline$t_{\mathrm{d}(\mathrm{n}-\mathrm{u})}, \mathrm{ns}$ & 3,26 & 3,4 & 3,61 & 3,79 \\
\hline$\delta t_{\mathrm{d}}, \%$ & $-4,4$ & $-2,9$ & $-1,4$ & $-0,33$ \\
\hline$\Delta F_{(\mathrm{u})}, \mathrm{GHz}$ & 0,15 & 0,3 & 1,05 & 1,1 \\
\hline$\Delta F_{(\mathrm{n}-\mathrm{u})}, \mathrm{GHz}$ & 0,15 & 0,25 & 1,0 & 1,1 \\
\hline$\delta F, \%$ & 0 & 20 & 5,0 & 0 \\
\hline$D_{(\mathrm{u})}$ & 0,467 & 0,99 & 3,738 & 4,158 \\
\hline$D_{(\mathrm{n}-\mathrm{u})}$ & 0,489 & 0,85 & 3,61 & 4,169 \\
\hline$\delta D, \%$ & $-4,6$ & 16 & 3,6 & $-0,26$ \\
\hline
\end{tabular}

MMVL pralaidumo juosta gali būti padidinta, nemažinant vèlinimo trukmès, padidinant tarpus tarp meandro strypu $S$. MMVL charakteristikų priklausomybė nuo tarpo tarp strypų pločio pateikta 4.10 lentelèje. Šio dydžio keitimas daro didelę itaką MMVL charakteristikoms. Pavyzdžiui, padidinus tarpą 4 kartus (nuo $0,25 \mathrm{~mm}$ iki $1 \mathrm{~mm}$ ), pralaidumo juosta plateja 7 kartus $(1,05 / 0,15 \cong 7$ ). 
Taip pat pažymètina, kad tolygios būdingosios varžos MMVL charakteristikos yra jautresnès tarpo tarp strypu pokyčiui, nei netolygios būdingosios varžos MMVL. Pavyzdžiui, didinant tarpą du kartus, tolygios būdingosios varžos MMVL $D$-faktorius didejja 0,99/0,467 = 2,5 karto, o netolygios būdingosios varžos MMVL $D$-faktorius šiuo atveju dideja tik $0,85 / 0,489 \cong 1,7$ karto (tolygios būdingosios varžos MMVL šiuo atveju yra $20 \%$ jautresnè už netolygios būdingosios varžos MMVL).

\subsection{Ketvirtojo skyriaus išvados}

Remiantis atliktais tyrimais ir jų rezultatų analize galima daryti šias išvadas:

1. Pasiūlytas ir igyvendintas programiniu kodu meandrinès mikrojuostelinès vèlinimo linijos (MMVL) modelis, grịstas baigtiniu skirtumų laiko srities (BSLS) metodu, leidžia gauti linijos laiko charakteristikas, o atlikus iejjimo ir išèjimo signalų Furje transformaciją - dažnines charakteristikas.

2. Pasiūlyto MMVL modelio adekvatumas patikrintas Sonnet ${ }^{\circledR}$ programų paketu. Dažninè amplitudès charakteristika, gauta taikant pasiūlytą modeli, praleidžiamujų dažnių juostos srityje skiriasi nuo Sonnet ${ }^{\circledR}$ programų paketu apskaičiuotos charakteristikos mažiau negu $2 \mathrm{~dB}$, o būdingosios varžos priklausomybès nuo dažnio - $4 \%$.

3. Atlikti skaičiavimai parodè, kad MMVL vèlinimo trukmé visuomet mažesnè negu tokio pat ilgio ir analogiškų skersinių konstrukcinių parametrų tiesès mikrojuostelinès perdavimo linijos dèl MMVL pirminių parametrų mažesnių verčių, sąlygotų meandro strypų tarpusavio sąveikos.

4. MMVL modelių, sudarytų pagal daugialaidžiu linijų metodą, analizès rezultatai atitinka CST Microwave Studio ${ }^{\circledR}$ ir Sonnet ${ }^{\circledR}$ specializuotu programų paketu gautus rezultatus - vèlinimo trukmès santykinis skirtumas neviršija $10 \%$. Ivertinus meandro kraštų jungiklių baigtinį ilgi minètas skirtumas sumažeja iki $7 \%$.

5. Meandrinès mikrojuostelinès vèlinimo linijos, grịstos tolygios būdingosios varžos daugialaidès mikrojuostelinès linijos modeliu, yra geriau suderintos su signalo perdavimo traktu, todèl jų pralaidumo juosta gali būti iki $20 \%$ platesnè, nei netolygios būdingosios varžos MMVL.

6. Vèlinimo trukmè tolygios būdingosios varžos MMVL atveju visada mažesnè, nei atitinkamų konstrukcinių parametrų netolygios būdingosios varžos MMVL. 



\section{Bendrosios išvados}

1. Pasiūlyti mikrojuostelinès perdavimo linijos, susietujų mikrojuostelinių linijų ir daugialaidžių mikrojuostelinių linijų modeliai, grįsti baigtinių skirtumų ir baigtinių skirtumų laiko srities metodais, leidžia tirti reguliarias ir nereguliarias meandrines mikrojuostelines vèlinimo linijas, sudarytas iš baigtinio strypų skaičiaus. Sudarytų modelių adekvatumas patikrintas lyginant sudarytais modeliais gautas elektrinių parametrų vertes su kitų autorių pateiktais analogiškų parametrų matavimų vertėmis.

2. Kompiuteriniais eksperimentais parodyta, kad sudarytieji meandrinès mikrojuostelinès vèlinimo linijos modeliai, grịsti baigtinių skirtumų laiko srities metodu, leidžia ịvertinti elektrinio lauko sklaidą laidininkuose ir elektrinių parametrų ties laidininkais kitimo pobūdị plačiame dažnių diapazone.

3. Kompiuteriniai tyrimai parodè, kad sinfazinè ir priešfazinè normaliosios bangos negali sklisti vienu metu tam tikros konstrukcijos daugialaide mikrojuosteline linija, galimas tik vienas iš dviejų darbo rěžimų. Taigi tolygiosios būdingosios varžos daugialaidè mikrojuostelinè linija gali būti susintezuota tik vienam sužadinimo būdui.

4. Kompiuteriniais eksperimentais parodyta, kad tolygios būdingosios varžos daugialaidžių mikrojuostelinių linijų sintezès algoritmas leidžia suprojektuoti liniją, kurios signalinių laidininkų būdingosios varžos vertès 
skiriasi mažiau negu $1 \%$, o tai leidžia gauti meandrinę mikrojuostelinę vèlinimo liniją, kurios pralaidumo juosta iki $20 \%$ platesnè nei linijos, suprojektuotos pagal periodinès daugialaidès linijos modeli.

5. Tyrimai parodè, kad išoriniai daugialaidès mikrojuostelinès linijos laidininkai daro didžiausią įtaka daugialaidès mikrojuostelinès linijos būdingosios varžos tolygumui ir, norint geriau suderinti meandrinę mikrojuostelinę vèlinimo liniją su signalo perdavimo traktu, užtenka keisti tik išorinių meandro strypu plotį.

6. Sudarytas tolygios būdingosios varžos daugialaidès mikrojuostelinès linijos sintezès algoritmas, paremtas baigtinių skirtumų metodo ir susietųjų matricų būdu, leidžia paspartinti meandrinès mikrojuostelinès vèlinimo linijos projektavimą kelis kartus lyginant su algoritmais, gristais baigtinių skirtumų metodu ir iteraciniu skaičiavimo būdu. 


\section{Literatūra ir šaltiniai}

Abielmona, S.; Gupta, S.; Caloz, C. 2007. Experimental Demonstration and Characterization of a Tunable CRLH Delay Line System for Impulse/Continuous Wave. Microwave and Wireless Components Letters 17(12): 864-866.

Ambhore, V. B.; Dhande, A. P. 2012. An Overview on Properties, Parameter Consideration And Design of Meandering Antenna, International Journal of Smart Sensors and Ad Hoc Networks (IJSSAN) 1(4): 59-62.

Arash, K.; Ramesh, A. 2006. Design of Compact Meander Delay Lines on Si Substrate, in Electrical Performance of Electronic Packaging, 141-144.

Bentaher, K.; Choubani, F.; Vuong, T. H.; David, J. 2011. Design of Non Uniform Meander Line Antennas for Passive RFID Tags in the UHF Band, in PIERS Proceedings, Marrakesh, Morocco, 400-403.

Berenger, J. P. 1994. A perfectly matched layer for the absorp-tion of electromagnetic waves, Journal of Computational Physics 114(2): 185-200.

Bertazzi, F.; Ghione, G.; Goano, M. 2003. Efficient quasi-TEM frequency-dependent analysis of lossy multiconductor lines through a fast reduced-order FEM model, IEEE Transactions on Microwave Theory and Techniques 51(9): 2029-2035.

Bogdanov, G.; Ludwig, R. 2002. Coupled microstrip line trans-verse electromagnetic resonator model for high-field magnetic resonance imaging, Magnetic Resonance in Medicine 47(3): 579-593. 
Bondeson, A.; Rylander, T.; Ingelström, P. 2005. Computational Electromagnetics. New York: Springer. 244 p.

Booton, R. C. 1992. Computational Methods for Electromagnetics and Microwaves. New York: Wiley-Interscience. 192 p.

Borja, A. L.; Belenguer, A.; Cascon, J.; Esteban, H.; Boria, V. E. 2011. Wideband Passband Transmission Line Based on Metamaterial-Inspired CPW Balanced Cells, IEEE Antennas and Wireless Propagation Letters 10: 1421-1424.

Boutboul M. S.; Kokabi H.; Pyée M. 1998. Modeling of microstrip quasi-TEM superconducting transmission lines, comparison with experimental results, Physica C: Superconductivity 309(1-2): 71-78.

Burokas, T.; Staras, S. 2008. Properties of the Retard System Models Based on the Complex Cross Section Multiconductor Lines, Electronics and Electrical Engineering 4(84): 3-8.

Chen, L.; Zhu, Q.; Xu, S. 2006. Delay lines based on left-handed transmission line structure, in IEEE Antennas and Propagation Society International Symposium, Albuquerque, Mexico, 1189-1192.

Cheng, K. K. M.; Everard, J. K. A. 1991. Accurate formulas for efficient calculation of the characteristic impedance of microstrip line, IEEE Transactions on Microwave Theory and Techniques 39(9): 1658-1661.

Chong, C. K.; Layman, D. A.; Stolz, R. J.; Levush, B.; Pasour, J. 2012. Development of high power K/Ka-band helix TWT, in IEEE Thirteenth International Vacuum Electronics Conference (IVEC), Monterey, USA, 119-120.

Coaker, B.; Challis, T. 2008. Travelling Wave Tubes: Modern Devices and Contemporary Applications, Microwave Journal 51(10): 32-46.

Daškevičius, V.; Skudutis, J.; Katkevičius, A.; Štaras, S. 2010. Simulation and Properties of the Wide-Band Hybrid Slow-Wave System, Electronics and Electrical Engineering 104(8): 43-46.

Davis, T. A. 2006. Direct Methods for Sparse Linear Systems. Philadelphia: Society for Industrial and Applied Mathematics. 217 p.

Eleftheriades, G. V.; Iyer, A. K.; Kremer, P. C. 2002. Planar negative refractive index media using periodically L-C loaded transmission lines, IEEE Transactions on Microwave Theory and Techniques 50(12): 2702-2712.

Feng, L.; Schutt-Aine, J. E.; Ji, C. 2002. Full-wave analysis and modeling of multiconductor transmission lines via 2-D-FDTD and signal-processing techniques, IEEE Transactions on Microwave Theory and Techniques 50(2): 570-577.

Garg, R. 2008. Analytical and computational methods in electromagnetics. London: Artech House Publishers. 528 p. 
GaWon, K.; Lu, A. C. W.; Fan, W.; Wai, L. L.; Joungho, K. 2008. 3D strip meander delay line structure for multilayer LTCC-based SiP applications, in Electronic Components and Technology Conference, Lake Buena Vista, USA, 2081-2085.

Gedney, S. D. 1996. An anisotropic perfectly matched layer-absorbing medium for the truncation, IEEE Transactions on Antennas and Propagation 44(12): 1630-1639.

Gedney, S. D. 2011. Introduction to the Finite-Difference Time-Domain (FDTD) Method for Electromagnetics. Morgan \& Claypool Publishers. 250 p.

Ghazali, A. N.; Pal, S. 2012. Analysis of a small UWB filter with notch and improved stopband, Progress In Electromagnetics Research Letters 34: 147-156.

Gibson, W. C. 2007. The Method of Moments in Electromagnetics. London: Chapman and Hall/CRC. 288 p.

Guansheng, L.; Tousi, Y. M.; Hassibi, A.; Afshari, E. 2009. Delay-Line-Based Analogto-Digital Converters, IEEE Transactions on Circuits and Systems II: Express Briefs 56(6): 464-468.

Gupta, S.; Caloz, C. 2010. Analog real-time Fourier transformer using a group delay engineered C-section all-pass network, in IEEE Antennas and Propagation Society International Symposium (APSURSI), Toronto, Canada, 1-4.

Gupta, S.; Caloz, C. 2011. Dispersion-compensation technique for log-periodic antennas using C-section all-pass dispersive delay structures, in IEEE International Symposium on Antennas and Propagation, Jeju, South Korea.

Gurskas, A.; Urbanavičius, V.; Martavičius, R. 2010. Evaluation of the Microstrip Lines Connectors in the Meander Delay Line Model, Elektronics and electrical engineering 3(99): 39-43.

Harrington, R. F. 1993. Field Computation by Moment Methods. New York: WileyIEEE Press. 240 p.

Higdon, R. L. 1986. Absorbing boundary-conditions for difference approximations to the multi-dimensional wave-equation, Mathematics of Computation 47 (176): 437-459.

Hoefer, D. G; Swanson, J.; Wolfgang, J. R. 2003. Microwave Circuit Modeling Using Elektromagnetic Field Simulation. Boston: Artech House Publishers. 47 p.

Hong-Ming, L.; Chih-Ming, T. 2009. Exact Synthesis of Broadband Three-Line Baluns, IEEE Transactions on Microwave Theory and Techniques 57(1):140-148.

Horii, Y.; Caloz, C.; Itoh, T. 2005. Super-compact multilayered left-handed transmission line and diplexer application, IEEE Transactions on Microwave Theory and Techniques 53(4): 1527-1534.

Horii, Y.; Gupta, S.; Nikfal, B.; Caloz, C. 2012. Multilayer Broadside-Coupled Dispersive Delay Structures for Analog Signal Processing, IEEE Microwave and Wireless Components Letters 22(1): 1-3. 
Hsi-Chou, H.; Jyh-Horng, W. 2007. Timing Synchronization in Ultra-Wideband Systems with Delay Line Combination Receivers, IEEE Communications Letters 11(3): 264-266.

Huarong G.; Travish, G.; Jin X.; Yanyu W.; Jinjun F.; Yubin G. 2013. High-Power Tunable Terahertz Radiation by High-Order Harmonic Generation, IEEE Transactions on Electron Devices 60(1): 482-486.

Hu J.; Xu R. 2009. X-band 3D meander stripline delay line using multilayer LTCC, in IEEE MTT-S International Microwave Symposium Digest, Boston, USA, 345-348.

Huang, C.; You, C. 1998. Analysis and design of inhomogeneous coupled-stripline microwave bandpass filters, Microwave Journal 41(9): 114-124.

Yanyan T.; Lingna Y.; Jin X.; Wenxiang W.; Yanyu W.; Yubin G.; Jinjun F. 2012. A Novel Slow-Wave Structure Folded Rectangular Groove Waveguide for MillimeterWave TWT, IEEE Transactions on Electron Devices 59(2): 510-515.

Yee, K. 1966. Numerical Solution of Initial Boundary Value Probles Involving Maxwell's Equations in Isotropic Media, IEEE Transactions on Antennas and Propagation 14 (3): 302-307.

Yi, W; Huang, F.; Lancaster, M. J.; Hieng, T. S. 2004. Design considerations of coplanar-to-coaxial transitions for wideband HTS delay lines, in 34th European Microwave Conference, Amsterdam, Netherlands, 177-180.

York, R. A.; Compton, R. C. 1990. Experimental evaluation of existing CAD models for microstrip dispersion, IEEE Transactions on Microwave Theory and Techniques 38(3): 327-328.

Yu-xiang W.; Ming-guang H.; Pu-Kun L.; Bao-Liang H. 2012. 2D FE code for the simulation and design of TWT electron guns, in International Conference on Microwave and Millimeter Wave Technology (ICMMT), Shenzhen, China, 1-4.

Jahanbakhshi, A.; Moradi, G.; Shirazi, R. S. 2012. Design and Simulation of Different Types of Meander Line Antennas with Improved Effciency, PIERS Proceedings, Moscow, Russia, 594-597.

Jain, N.; Brown, B. 1997. Dispersion characteristics of microstrip transmission line on glass microwave IC's, IEEE Microwave and Guided Wave Letters 7(10): 344-346.

Jamil, A.; Yusoff, M. Z.; Yahya, N.; Zakariya, M. A.; 2011. A compact multiband hybrid meander-Koch Fractal antenna for WLAN USB dongle, in IEEE Conference on Open Systems (ICOS), Langkawi, Archipelago, 290-293.

Jansen, R. H. 1978. High-Speed Computation of Single and Coupled Microstrip Parameters Including Dispersion, High-Order Modes, Loss and Finite Strip Thickness, IEEE Transactions on Microwave Theory and Techniques 26(2): 75-82.

Katkevičius, A.; Mališauskas, V.; Plonis, D.; Serackis, A. 2012. Calculations of characteristics of microwave devices using artificial neural networks, Electrical Review 88(1a): 281-285. 
Kim, M.; Hacker, J. B.; Mihailovich, R. E.; DeNatale, J. F. 2001. A DC-to-40 GHz fourbit RF MEMS true-time delay network, IEEE Microwave and Wireless Components Letters 11(2): 56-58.

Kim, H.; Bien, F.; Hur, Y.; Chandramouli, S.; Cha, J.; Gebara, E.; Laskar, J. 2007. A 0.25-um BiCMOS Feed Foward Equalizer Using Active Delay Line for Backplane Communication, in IEEE International Symposium on Circuits and Systems (ISCAS), New Orleans, USA, 193-196.

Kirvaitis, R. 1994. Elektrodinaminès vèlinimo linijos. Vilnius: Technika. 215 p.

Kleiza, A.; Štaras, S. 2000. Sudètingų lètinimo sistemų charakteristikų skaičiavimas neišvedant dispersinių lygčių, Elektronika ir elektrotechnika 6(29): 39-45.

Kolmakov, I.; Gashinova, M.; Kolmakov, J.; Deleniv, A. 2002. Full-wave 3D analysis of boxed microwave planar structures based on high-Tc superconducting films on ferrite substrate, in 32nd European Microwave Conference, Milan, Italy, 1-3.

Kotiranta, M.; Krozer, V.; Zhurbenko, V. 2010. Square helix TWT for THz frequencies, in 35th International Conference on Infrared Millimeter and Terahertz Waves (IRMMW$\mathrm{THz}$ ), Rome, Italy, 1-2.

Lai, A.; Itoh, T.; Caloz, C. 2004. Composite right/left-handed transmission line metamaterials, IEEE Microwave Magazine 5(3): 34-50.

Liang, G. C.; Withers, R. S.; Cole, B. F.; Garrison, S. M.; Johansson, M. E.; Ruby, W. S.; Lyons, W. G. 1993. High-temperature superconducting delay lines and filters on sapphire and thinned $\mathrm{LaAlO}_{3}$ substrates, IEEE Transactions on Applied Superconductivity 3(3): 3037-3042.

Ling-jiang, Z.; Bo, Z.; Zheng-hui, X.; Wei-ming L.; Wu, R. 2012. Analysing periodic structures using FDTD algorithm, in International Conference on Microwave and Millimeter Wave Technology (ICMMT), Shenzhenm, China, 1-4.

Liu, F.; Schutt-Aine, J. E.; Chen, J. 2002. Full-wave analysis and modelling of multiconductor transmission lines via 2-D-FDTD and signal-processing techniques, IEEE Transactions on Microwave Theory and Techniques 50(2): 570-577.

Maleki, S. J.; Dousti, M. 2012. A compact dual-band bandpass filter using microstrip meander loop and square loop resonators, IEICE Electronics Express 9(16): 1342-1348.

Manz, B. 2009. Advancing TWTs: the traveling wave tube lives on and on, Journal of Electronic Defense 32(7): 26-30.

Marimuthu, J.; Abbosh, A. M.; Henin, B. 2013. Planar microstrip bandpass filter with wide dual bands using parallel-coupled lines and stepped impedance resonators, Progress In Electromagnetics Research C 35: 49-61.

Metlevskis, E.; Urbanavičius, V. 2011. Analysis of charge distribution on rectangular microstrip structures, Acta Physica Polonica A 119(4): 503-508.

Metlevskis, E.; Martavičius, R. 2012. Computer Models of Meander Slow-Wave System with Additional Shields, Elektronics and electrical engineering 3(119): 61-64. 
Mikučionis, Š.; Urbanavičius, V. 2010. Synthesis of microstrip multiconductor lines, operating in normal mode, in 18th International Conference on Microwave Radar and Wireless Communications (MIKON), Lithuania, Vilnius, 1-4.

Mikučionis, Š.; Urbanavičius, V. 2011. Synthesis of six-conductors symmetrically coupled microstrip line, operating in a normal mode, Elektronika ir elektrotechnika 110(4): $47-52$.

Mittal, S.; Kaushik, B. K.; Yadav, K. L.; Sharma, D. K.; Majumder, M. K. 2012. Crosstalk effect in coupled interconnect lines using FDTD method, in International Conference on Communications, Devices and Intelligent Systems (CODIS), Kolkata, India, $365-368$.

Misman, D.; Husain, M. N.; Abd Aziz, M. Z. A.; Salamat, I. A.; Kadir, M. F. A.; Rose, M. R. C.; Shah, M.; Soh, P. J. 2008. The Study of Different Impedance Meander Line for Microstrip Antenna Design, in 6th National Conference on Telecommunication Technologies and 2nd Malaysia Conference on Photonics, Putrajaya, Malaysia, 117120.

Mohra, A. S. 2009. Coupled microstrip line bandpass filter with harmonic suppression using right-angle triangle grooves, Microwave and Optical Technology Letters 51(10): 2313-2318.

Mur, G. 1981. Absorbing boundary-conditions for the finite-difference approximation of the time-domain electromagnetic-field equations, IEEE Transactions on Electromagnetic Compatibility 23(4): 377-382.

Nara, S.; Koshiji, K. 2006. Study on delay time characteristics of multilayered hyper-shielded meander line, in IEEE International Symposium on Electromagnetic Compatibility, Portland, USA, 760-763.

Neapolitan, E. R.; Naimipour, K. 2004. Foundations of algorithms using Java pseudocode. Jones \& Bartlett Learning. 618 p.

Nikfal, B.; Gupta, S.; Caloz, C. 2011. Increased Group-Delay Slope Loop System for Enhanced-Resolution Analog Signal Processing, IEEE Transactions on Microwave Theory and Techniques 59(6): 1622-1628.

Niu, J. X. 2010. Dual-band dual-mode patch antenna based on resonant-type metamaterial transmission line, Electronics Letters 46(4): 266-268.

Pinto, M. N.; Xavier, C. C.; Motta, C. C. 2011. An electron gun design for a C-band TWT, in SBMO/IEEE MTT-S International Microwave \& Optoelectronics Conference (IMOC), Natal, Brazil, 937-940.

Qingfeng, Z.; Sounas, D. L.; Caloz, C. 2013. Synthesis of Cross-Coupled ReducedOrder Dispersive Delay Structures (DDSs) With Arbitrary Group Delay and Controlled Magnitude, IEEE Transactions on Microwave Theory and Techniques 61(3): 10431052. 
Rawat, K.; Ghannouchi, F. M. 2009. A Design Methodology for Miniaturized Power Dividers Using Periodically Loaded Slow Wave Structure With Dual-Band Applications, IEEE Transactions on Microwave Theory and Techniques 57(12): 3380-3388.

Roden, J. A.; Gedney, S. D. 2000. Convolutional PML (CPML): An Efficient FDTD Implementation of the CFS-PML for Arbitrary Media, Microwave and Optical Technology Letters 27(5): 334-339.

Rodgers $^{\circledR} \quad$ [interaktyvus] 2013 [žiūrèta $2013 \quad 08$ 04]. Interneto prieiga: $<$ http:/www.rogerscorp.com/documents/722/acm/RO3000-Laminate-Data-SheetRO3003-RO3006-RO3010.pdf>.

Rosales, O. S.; Suster, D. 1995. Finite-difference computation of the characteristic impedance of unbounded striplines and microstrip lines, in Proceedings of the 1995 First IEEE International Caracas Conference on Devices, Circuits and Systems, Caracas, Venezuela, 323-327.

Rubin, B. J.; Singh, B. 2000. Study of meander line delay in circuit boards, IEEE Transactions on Microwave Theory and Techniques 48(9): 1452-1460.

Sadiku, M. N. O. 2009. Numerical Techniques in Electromagnetics with MATLAB. New York: CRC Press. 648 p.

Sadiku, M. N. O; Obiozor, C. N. 2000. A comparison of finite difference time-domain (FDTD) and transmission-line modeling (TLM) methods, in Proceedings of the IEEE Southeastcon 2000, Nashville, USA, 19-22.

Sanggu P.; Sanggeun J. 2013. A 15-40 GHz CMOS True-Time Delay Circuit for UWB Multi-Antenna Systems, IEEE Microwave and Wireless Components Letters 23(3): 149151.

Schneider, M. V. 1972. Microstrip dispersion, Proceedings of the IEEE 60(1): 144-146.

Sheng, S.; Ong, C. K. 2012. Coupled microstrip line microwave phase shifter using ferroelectric thin film varactors, Journal of Applied Physics 111(4): 044506-044506044505.

Sroka, J. 2003. Oscilloscope influence on the calibration uncertainty of the pulse rise time of ESD simulators, in International Symposium on Electromagnetic Compatibility, Istanbul, Turkey, 378-381.

Swanson, D. G.; Hoefer, W. J. R. 2003. Microwave circuit modeling using electromagnetic field simulation. Boston: Artech House Publishers. $474 \mathrm{p}$.

Štaras, S. 2008. Ivadas $\underline{i}$ skaitmeninius elektrodinamikos metodus ir jų taikymą. Vilnius: Technika. $186 \mathrm{p}$.

Štaras, S.; Skudutis, J. 1999. Traveling-wave deflecting systems, Software for Electrical Engineering Analysis and Design IV 2: 23-32.

Staras, S.; Burokas, T. 2006. Frequency-Dependent Distortions of Pulses in the Traveling-Wave Cathode-Ray Tubes, in International Conference on Microwaves, Radar \& Wireless Communications, Krakow, Poland, 812-815. 
Štaras, S. Martavičius, R.; Skudutis, J.; Urbanavičius, V.; Daškevičius, V. 2010. Plačiajuosčių lètinimo ịtaisų modeliavimas ir taikymas: monografija. Vilnius: Technika. 442 p.

Štaras, S.; Martavičius, R.; Skudutis, J.; Urbanavičius, V.; Daškevičius, V. 2012. Wideband slow-wave systems: simulation and application. New York: Taylor \& Francis Group. 460 p.

Taflove, A.; Hagness, S. C. 2005. Computational Electrodynamics: the Finite-difference Time-domain Method. Artech House. 1006 p.

Taufiqqurrachman, Arisesa, H. 2012. Design and Implementation of 2-Way Wilkinson Power Divider at Intermediate Frequency $456 \mathrm{MHz}$ using FR4 Substrate, International Journal of Engineering \& Technology IJET-IJENS 12(6): 14-19.

Thom, A.; Apelt, C. J. 1961. Field Computations in Engineering and Physics. London: D. Van Nostrand. $165 \mathrm{p}$.

Tiong, S. H.; Wang, Y.; Huang, F.; Lancaster, M. J. 2008. Superconducting Delay Lines, Journal of Superconductivity and Novel Magnetism 21(1): 7-16.

Topsakal, E.; Volakis, J. 2003. Finite element method for the accurate analysis of delay line propagation characteristics, in IEEE International Symposium on Electromagnetic Compatibility, Istanbul, Turkey, 1074-1076.

Trani, P.; Antoine, P. 2012. MPM for ECM systems, in IEEE Thirteenth International Vacuum Electronics Conference (IVEC), Monterey, USA, 149-150.

Tur, M. 2009. True time delay photonic beamforming: A review, in IEEE International Conference on Microwaves, Communications, Antennas and Electronics Systems, Tel Aviv, Israel, 1-2.

Ulisse, G.; Brunetti, F.; Di Carlo, A. 2012. Study of geometrical tolerances of an electron gun for $\mathrm{THz}$ vacuum tube, in IEEE International Conference on Plasma Science (ICOPS), Edinburgh, UK, 3-4.

Urbanavičius, V.; Martavičius, R. 2006. Model of the microstrip line with a non-uniform dielectric, Electronics and Electrical Engineering 67(3): 55-60.

Urbanavičius, V.; Gurskas, A.; Martavičius, R. 2009. Simulation of the Meander Delay Line Using the Hybrid Method, Electronics and Electrical Engineering 90(2): 6-9.

Vainoris, Z. 2004. Bangu elektronikos pagrindai. 1-oji laida. Vilnius: Technika. 513 p.

Vemuri, R. V.; Karplus, W. J. 1981. Digital Computer Treatment of Partial Differential Equations. New Jersey: Prentice Hall. 480 p.

Vendik, I.; Deleniv, A.; Gashinova, M.; Kolmakov, I.; Kolmakov, Y. 2003. Full-wave 2D and 3D spectral domain analysis of HTS multistrip multilayer lossy structure, IEEE Transactions on Applied Superconductivity 13(2): 269-271.

Watanabe, K.; Sekine, T.; Takahashi, Y. 2009. A FDTD method for Nonuniform Transmission Line Analysis Using Yee's-lattice and Wavelet Expansion, in IEEE MTT-S International Microwave Workshop Series on Signal Integrity and High-Speed Interconnects, Guadalajara, Mexico, 83-86. 
Weiss, J. A. 1974. Dispersion and Field Analysis of a Microstrip Meander-Line SlowWave Structure, IEEE Transactions on Microwave Theory and Techniques 22(12): 1194-1201.

Wei-Tsung L.; Yun-Chieh C.; Jeng-Han T.; Hong-Yuan Y.; Jen-Hao C.; Tian-Wei H. 2013. 60-GHz 5-bit Phase Shifter With Integrated VGA Phase-Error Compensation, IEEE Transactions on Microwave Theory and Techniques 61(3): 1224-1235.

Wenjia, T.; Hongjoon, K. 2009. Compact, tunable large group delay line, in Wireless and Microwave Technology Conference, Clearwater, USA, 1-3.

Wheeler, H. A. 1964. Transmission-line properties of parallel wide strips by a conformal-mapping approximation, IEEE Microwave theory and techniques 12(3): 280-289.

Wujian X.; Li W.; Yong L.; Guo L. 2012. Improved design of an output structure for Wband Gyro-TWT, in International Conference on Computational Problem-Solving (ICCP), Leshan, China, 392-394.

Zyuryukin, Y. A.; Lyamin, A. G. 2006. Analysis by Multiconductor Line Method of the Piezoelectric Travelling Wave Transducer in the Form of Flat Meander with Oneside Arrangement of Piezocapacistance Loadings, in International Conference on Actual Problems of Electron Devices Engineering, Saratov, Russia, 269-275.

Вайнорис, 3.; Кирвайтис, Р.; Штарас, С. 1986. Электродинамические задерживающие и отклоняющие системы. Вильнюс: Мокслас. 266 с. 



\section{Autoriaus mokslinių publikaciju disertacijos tema sąrašas}

\section{Straipsniai recenzuojamuose mokslo žurnaluose}

Krukonis, A. 2010. Baigtiniu skirtumų metodo skaičiavimo būdų tyrimas, Mokslas Lietuvos ateitis. 2(1): 103-107. ISSN 2029-2252. (Inspec).

Pomarnacki, R.; Krukonis, A.; Urbanavičius, V. 2010. Parallel Algorithm for the QuasiTEM Analysis of Microstrip Multiconductor Line, Electronics and Electrical Engineering 5(101): 83-86. ISSN 1392-1215. (ISI Web of Science).

Pomarnacki, R.; Krukonis, A. 2011. Parallel Algorithm for the Quasi-TEM Analysis of Microstrip Multiconductor Line, Mokslas - Lietuvos ateitis. 3(1): 104-109. ISSN 20292252. (ICONDA, Gale ${ }^{\circledR}$, ProQuest, EBSCOhost, IndexCopernicus).

Krukonis, A.; Urbanavičius, V. 2011. Investigation of Microstrip Lines Dispersion by the FDTD Method, Electronics and Electrical Engineering 9(115): 83-86. ISSN 13921215. (ISI Web of Science).

Krukonis, A.; Mikučionis, Š. 2013. Susietujų mikrojuostelinių linijų dažninès charakteristikos, Mokslas - Lietuvos ateitis. 2(1): 103-107. ISSN 2029-2252. (ICONDA, Gale ${ }^{\circledR}$, ProQuest, EBSCOhost, IndexCopernicus).

Krukonis, A.; Mikučionis, Š; Urbanavičius, V. 2013. The Influence of Non-Uniformity of the Multi-Conductor Line Parameters on Frequency Responses of the Meander Delay 
Line, Electronics and Electrical Engineering 19(6): 81-86. ISSN 1392-1215. (ISI Web of Science).

\section{Straipsniai kituose leidiniuose}

Krukonis, A.; Urbanavičius, V. 2012. Multiconductor microstrip line modelling using FDTD method, in Proceedings of the 22nd international conference "Electromagnetic disturbances EMD'2012”, Vilnius, Lietuva, 60-63. [Tarptautinès konferencijos „EMD‘2012“, ịvykusios Vilniuje 2012 m. rugsèjo 20-21 d., mokslinių pranešimų rinkinys]. Vilnius: Technika, 60-63. ISSN 1822-3249. ISBN 9786094572609. 
Audrius KRUKONIS

MIKROJUOSTELINIỤ LĖTINIMO SISTEMŲ TYRIMAS DAŽNINIAIS

IR LAIKO SRITIES METODAIS

Daktaro disertacija

Technologijos mokslai,

elektros ir elektronikos inžinerija (01T)

INVESTIGATION OF MICROSTRIP DELAY SYSTEMS

IN FREQUENCY AND TIME DOMAIN

Doctoral Dissertation

Technological Sciences,

Electrical and Electronic Engineering (01T)

201310 21. 11,5 sp. I. Tiražas 20 egz.

Vilniaus Gedimino technikos universiteto

leidykla „Technika“,

Saulètekio al. 11, 10223 Vilnius,

http://leidykla.vgtu.It

Spausdino UAB "Ciklonas“

J. Jasinskio g. 15, 01111 Vilnius 